\title{
CaMKII-dependent regulation of ion channels and its role in cardiac arrhythmias
}

\author{
Dissertation \\ zur Erlangung des Doktorgrades \\ der Mathematisch-Naturwissenschaftlichen Fakultäten \\ der Georg-August-Universität zu Göttingen \\ vorgelegt von \\ Nataliya Dybkova \\ aus Kiew/Ukraine
}

Göttingen 2008 
D7

Referent:

Prof. Dr. R. Hardeland

Korreferent

Prof. Dr. D. Doenecke

Tag der mündlichen Prüfung: 3 Juli 2008 


\section{Contents}

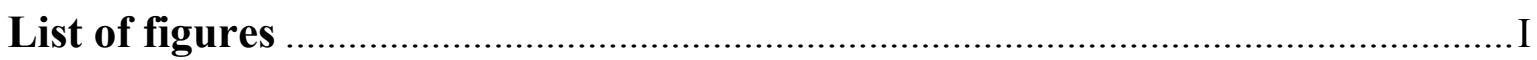

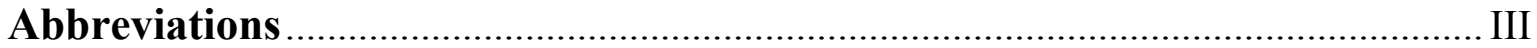

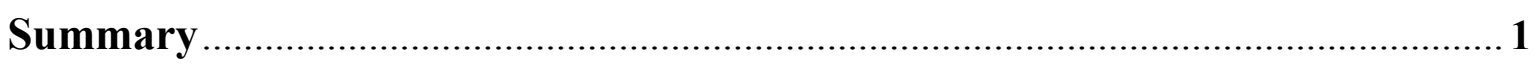

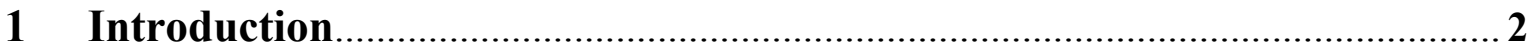

$1.1 \mathrm{Ca}^{2+}$ as a critical second messenger in cardiac myocytes........................................ 2

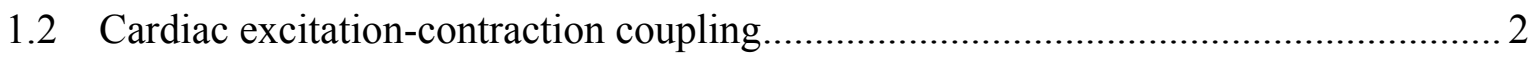

1.3 Modulation of E-C coupling via $\mathrm{Ca}^{2+} /$ calmodulin-dependent protein kinase II .......... 4

1.3.1 Structure of $\mathrm{Ca}^{2+} /$ calmodulin-dependent protein kinase II .................................... 5

1.3.2 Phosphorylation of L-type $\mathrm{Ca}^{2+}$ channels by CaMKII results in $\mathrm{Ca}^{2+}$ -

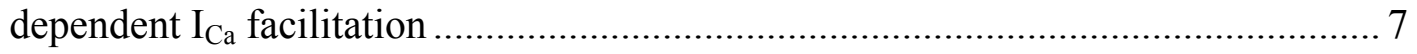

1.3.3 Enhancement of SERCA2a activity and $\mathrm{SR} \mathrm{Ca}^{2+}$ uptake upon PLB

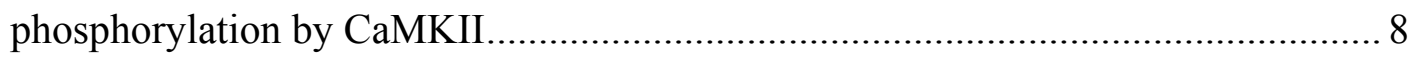

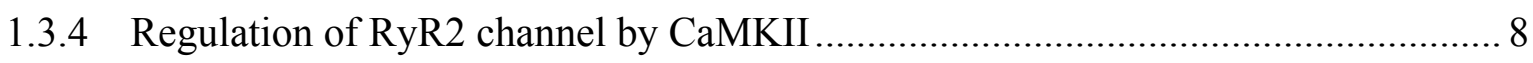

1.4 Role of CaMKII in the development of heart failure ............................................ 10

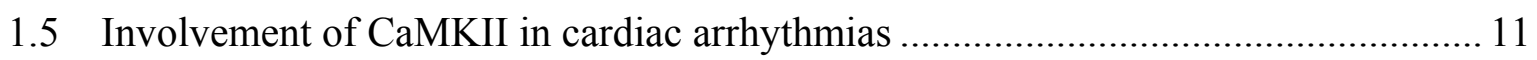

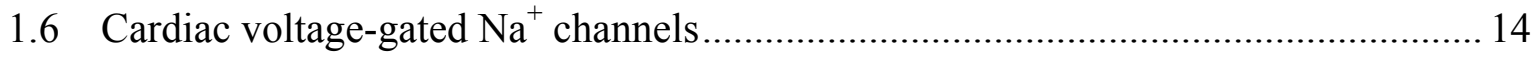

1.6.1 The structure and function of $\mathrm{Na}^{+}$channels ..................................................... 14

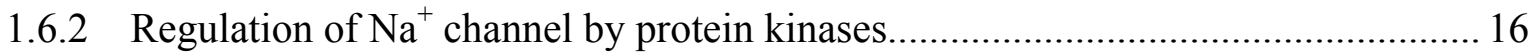

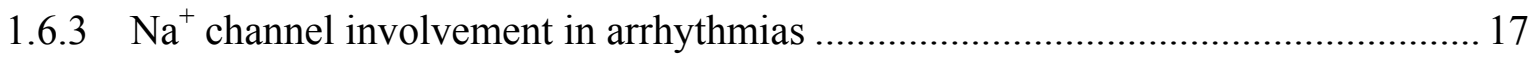

1.7 Mutations in cardiac RyR2 gene as a cause for cardiac arrhythmias ....................... 18

1.7.1 RyR2 regulates cardiac contraction and rhythm.............................................. 18

1.7.2 Catecholaminergic polymorphic ventricular tachycardia.................................... 18

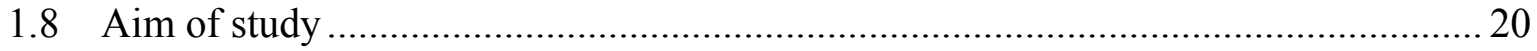

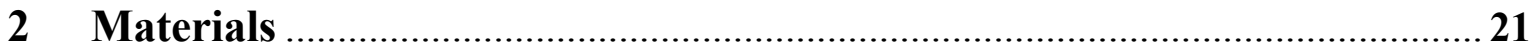

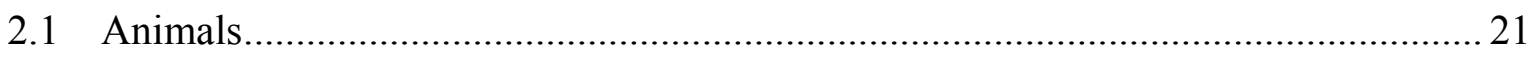

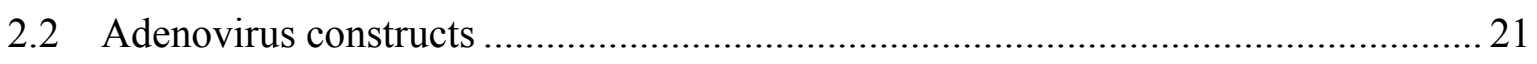

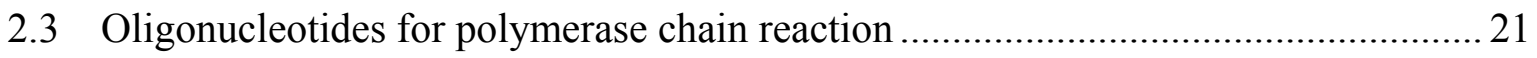

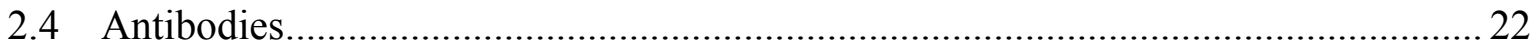

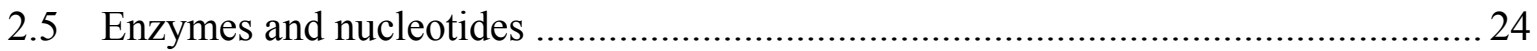

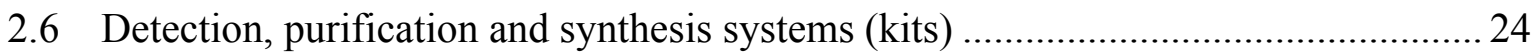

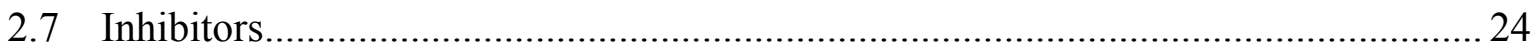

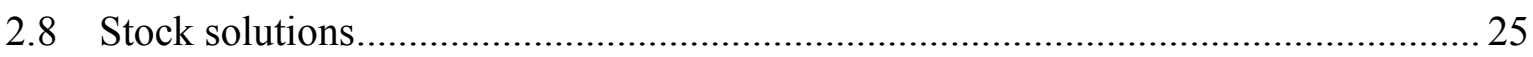

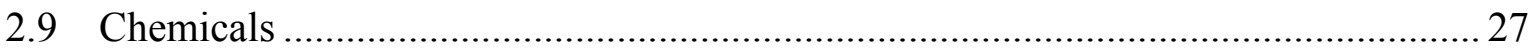


Contents

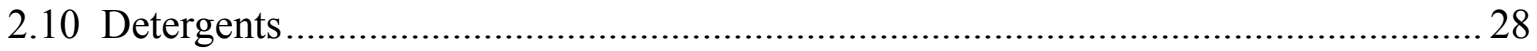

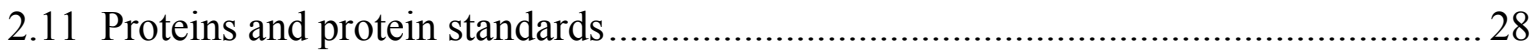

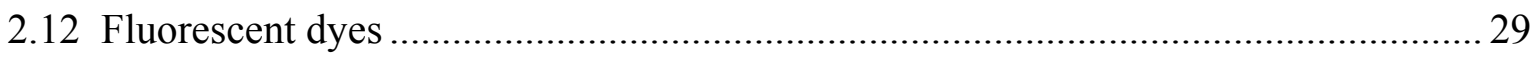

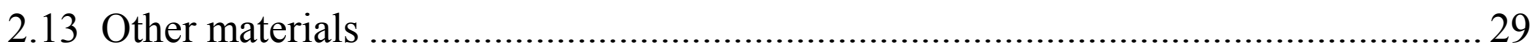

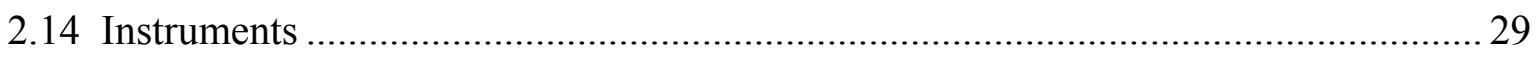

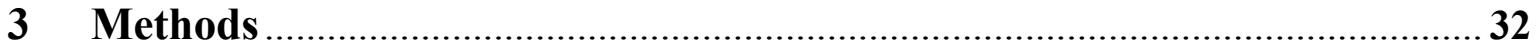

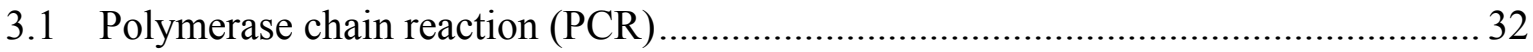

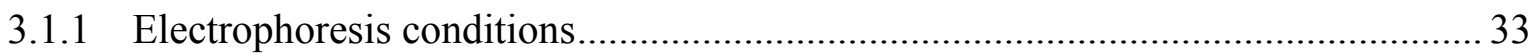

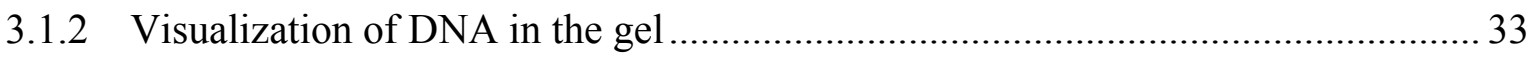

3.2 Adenoviral transfection and culture of adult rabbit ventricular cardiomyocytes ....... 34

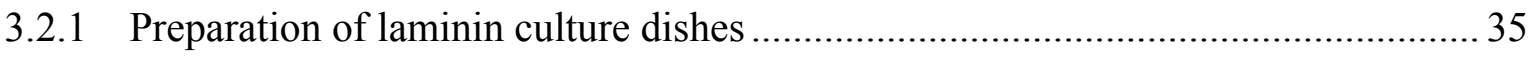

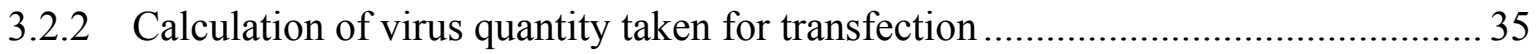

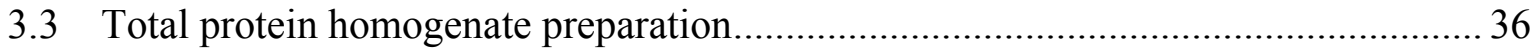

3.3.1 Protein lysate preparation from rabbit ventricular cardiomyocytes ........................ 36

3.3.2 Protein homogenate preparation from mouse heart tissue.................................... 37

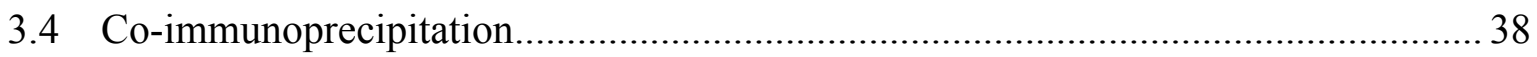

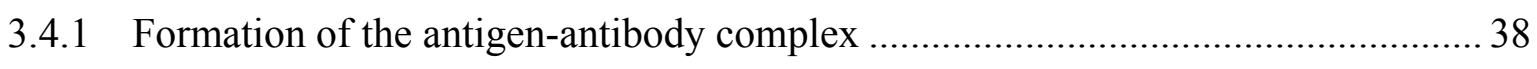

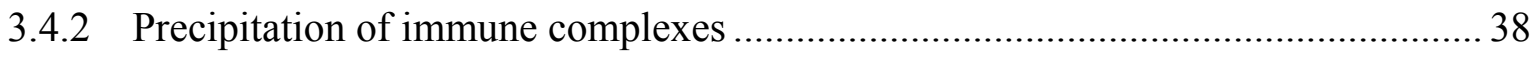

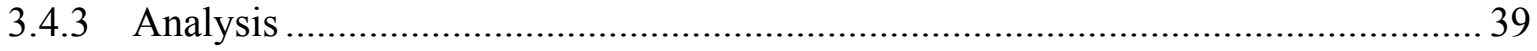

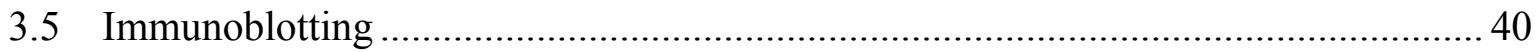

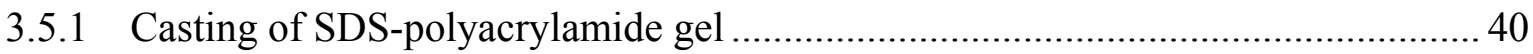

3.5.2 SDS-polyacrylamide gel electrophoresis (SDS-PAGE) and electrophoretic

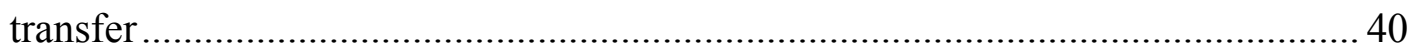

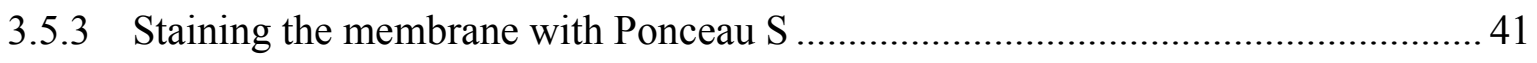

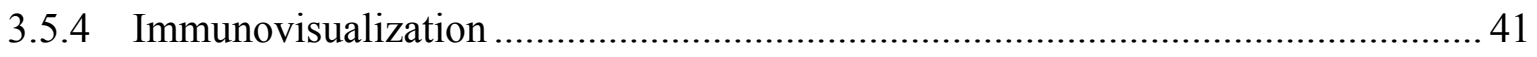

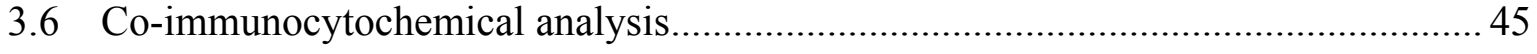

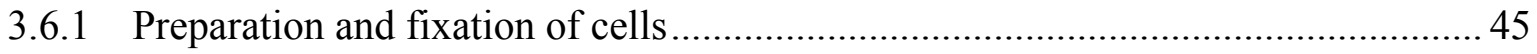

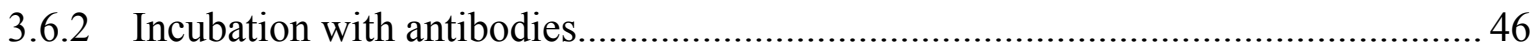

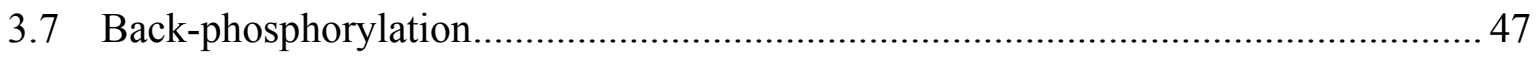

3.7.1 Immunoprecipitation of $\mathrm{Na}^{+}$channel from mouse cardiac homogenates................ 47

3.7.2 Preactivation of endogenous CaMKII and immunoprecipitation of $\mathrm{Na}^{+}$

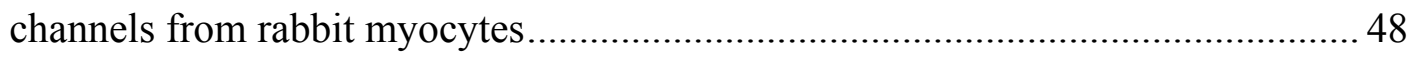

3.7.3 Preactivation of exogenous CaMKII and back-phosphorylation .......................... 48

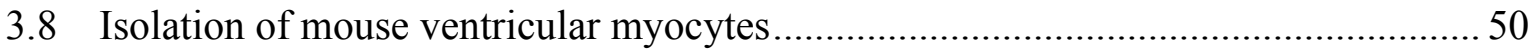


Contents

3.9 Measurement of cell shortening and $\mathrm{Ca}^{2+}$ transients using an epifluorescence

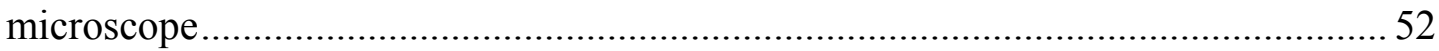

3.10 Measurement of the $\mathrm{Ca}^{2+}$ sparks using confocal microscope...................................... 55

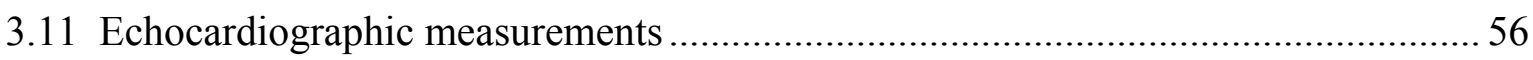

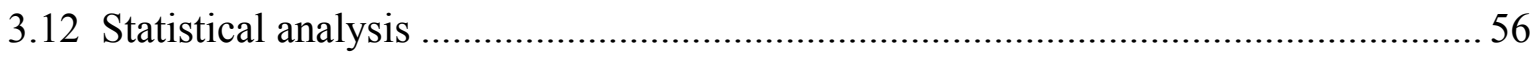

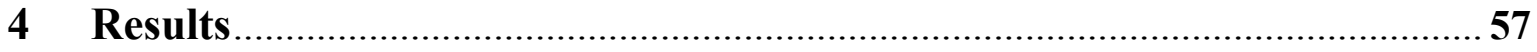

4.1 Association with and phosphorylation of $\mathrm{Na}^{+}$channels by CaMKII ........................ 57

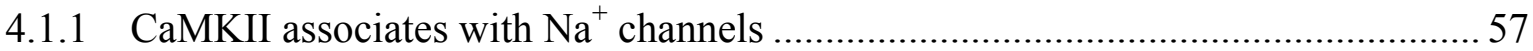

4.1.2 Immunocolocalization of CaMKII and $\mathrm{Na}^{+}$channels in single cardiomyocytes .... 59

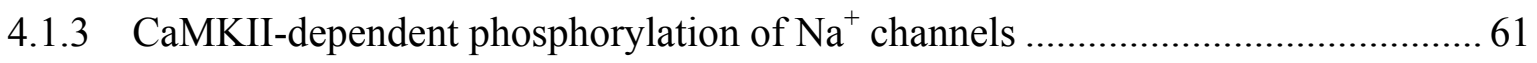

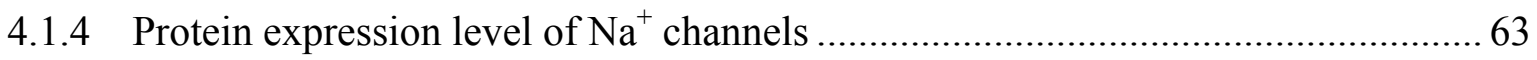

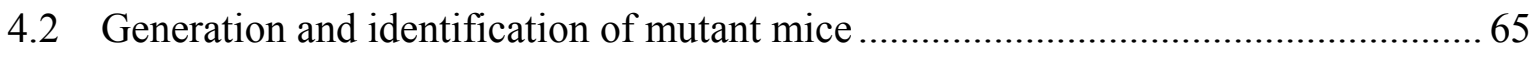

4.2.1 PCR-mediated verification of genotypes of mutant mice ....................................6 65

4.2.2 Cardiac overexpression of CaMKII $\delta_{\mathrm{C}}$ in CaMKII $\delta \mathrm{c}$ TG and RyR2 ${ }^{\mathrm{R} 4496 \mathrm{C}+/}$ mice induces cardiac hypertrophy and mortality.

4.3 Echocardiographic analysis of RyR2 ${ }^{\mathrm{R} 4496 \mathrm{C}+/}, \mathrm{CaMKII}_{\mathrm{C}} / \mathrm{RyR}^{\mathrm{R} 4496 \mathrm{C}}, \mathrm{CaMKII} \delta_{\mathrm{C}}$

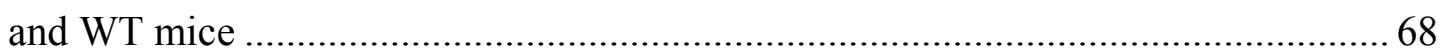

4.4 Analysis of cardiomyocyte shortening and $\mathrm{Ca}^{2+}$ transients using an

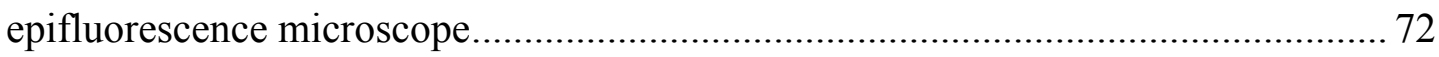

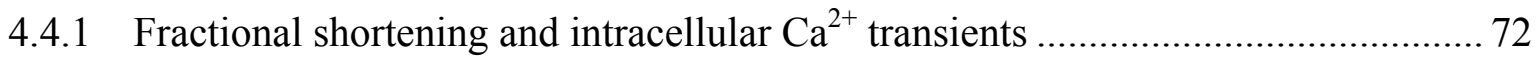

4.4.2 Frequency-dependence of shortening, intracellular $\mathrm{Ca}^{2+}$ transients and relaxation

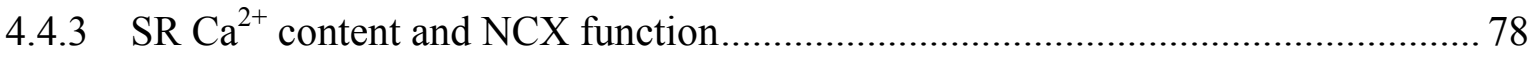

4.5 Expression levels of important $\mathrm{Ca}^{2+}$ transport proteins in mouse hearts.................... 82

4.6 Measurement of $\mathrm{Ca}^{2+}$ release from the SR using confocal microscopy ..................... 85

4.7 Increased arrhythmogenic events in RyR2 $2^{\mathrm{R} 4496 \mathrm{C}+/}$, CaMKII $\delta_{\mathrm{C}} / \mathrm{RyR} 2^{\mathrm{R} 4496 \mathrm{C}}$ and

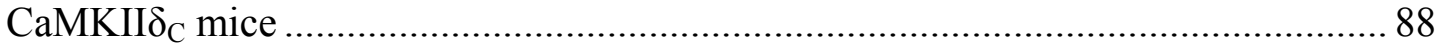

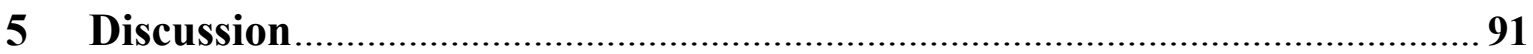

5.1 CaMKII $\delta_{\mathrm{C}}$ associates with and phosphorylates cardiac $\mathrm{Na}^{+}$channels ...................... 91

5.2 Functional characterization of $\mathrm{RyR} 2^{\mathrm{R} 4496 \mathrm{C}+/}$ mice harboring a human CPVT mutation.

5.3 Overexpression of $\mathrm{CaMKII} \delta_{\mathrm{C}}$ in mouse hearts bearing the R4496C mutation leads to arrhythmias and increased mortality 
Contents

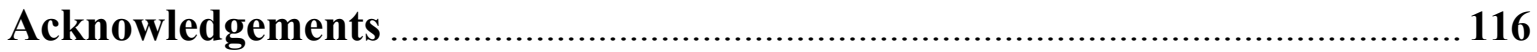

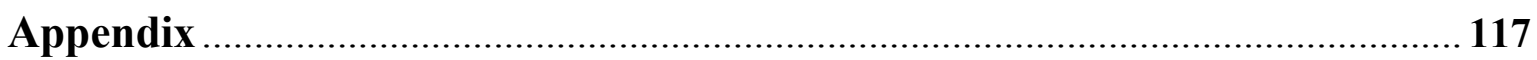




\section{List of figures}

Fig. 1 General scheme of $\mathrm{Ca}^{2+}$ cycle in a cardiac ventricular myocyte 3

Fig. 2 Effects of CaMKII $\delta_{\mathrm{C}}$ on excitation-contraction coupling 5

Fig. 3 Domain layout and oligomeric organization of CaMKII 6

Fig. 4 Cardiac pathology in CaMKII $\delta_{\mathrm{C}}$ TG mice 11

Fig. 5 Representative $\mathrm{Ca}^{2+}$ sparks in CaMKII $\delta_{\mathrm{C}}$ TG versus WT mice 12

Fig. $6 \quad$ Structure of cardiac $\mathrm{Na}^{+}$channel Nav1.5 (SCN5A) 14

Fig. 7 Association of CaMKII with all $\mathrm{Na}^{+}$channel isoforms $\left(\mathrm{Pan} \mathrm{Na}_{\mathrm{v}}\right)$ in 57 Triton X-100-solubilized cardiac mouse homogenate and rabbit lysates.

Fig. 8 Association of CaMKII with the cardiac $\mathrm{Na}^{+}$channel $\left(\mathrm{Na}_{\mathrm{v}} 1.5\right)$ isoform in Triton X-100-solubilized cardiac mouse homogenate and rabbit lysates

Fig. 9 Co-localization of CaMKII and $\mathrm{Na}^{+}$channels in mouse and rabbit cardiomyocytes

Fig. 10 Phosphorylation of $\mathrm{Na}^{+}$channel in cardiac mouse homogenate and rabbit lysates by either exogenous or endogenous CaMKII

Fig. 11 Protein expression levels of $\mathrm{Na}^{+}$channel in mice $\left(\mathrm{CaMKII} \delta_{\mathrm{C}} \mathrm{TG}\right.$ versus WT) and in transfected rabbit myocytes $\left(\mathrm{CaMKII} \delta_{\mathrm{C}}\right.$ versus $\beta$ gal, MOI of 100, 24 hours)

Fig. 12 PCR confirmation of CaMKII $\delta_{\mathrm{C}} \mathrm{TG}, \mathrm{RyR} 2^{\mathrm{R} 4496 \mathrm{C}+/-}$ knock-in and WT mouse genotypes

Fig. 13 CaMKIII $\delta_{\mathrm{C}}$ overexpression in mouse hearts induced cardiac hypotrophy

Fig. 14 Overexpression of CaMKII $\delta_{\mathrm{C}}$ led to sudden premature death 68

Fig. 15 Dilated cardiomyopathy and cardiac dysfunction at the whole heart level in vivo in CaMKII $\delta_{\mathrm{C}} / \mathrm{RyR}^{\mathrm{R} 4496 \mathrm{C}}$ and CaMKII $\delta_{\mathrm{C}}$ mice.

Fig. 16 Averaged structural echocardiographic parameters for WT, 70 RyR2 ${ }^{\text {R4496C+/- }}$, CaMKII $\delta_{\mathrm{C}} / \mathrm{RyR}^{\mathrm{R} 4496 \mathrm{C}}$ and CaMKII $\delta_{\mathrm{C}}$ mice

Fig. 17 Averaged functional echocardiographic parameter for WT, 71 RyR2 $2^{\text {R4496C+/- }}$, CaMKII $\delta_{\mathrm{C}} / \mathrm{RyR}^{\mathrm{R} 4496 \mathrm{C}}$ and CaMKII $\delta_{\mathrm{C}}$ mice

Fig. 18 Frequency-dependent changes in $\mathrm{Ca}^{2+}$ transient amplitude in isolated 
cardiomyocytes measured using Fluo-3

Fig. 19 Frequency-dependent changes in fractional shortening in isolated cardiomyocytes measured using a sarcomere length detection system

Fig. 20 Frequency-dependent changes in $\mathrm{Ca}^{2+}$ transients and fractional 76 shortening

Fig. 21 Frequency-dependent acceleration of relaxation 77

Fig. 22 Caffeine-induced $\mathrm{Ca}^{2+}$ transients 79

Fig. $23 \mathrm{SR} \mathrm{Ca}^{2+}$ content in cardiomyocytes $\quad 80$

$\begin{array}{lll}\text { Fig. } 24 & \text { NCX function } & 80\end{array}$

Fig. $25 \quad$ Fractional $\mathrm{SR} \mathrm{Ca}^{2+}$ release $\quad 81$

Fig. 26 (A) Representative Western blots of important $\mathrm{Ca}^{2+}$ cycling proteins 83 from cardiac homogenates prepared from hearts of RyR2 $2^{\mathrm{R} 4496 \mathrm{C}+/}$ and WT mice. (B) Quantification of the protein expression level in $\mathrm{RyR} 2^{\mathrm{R} 4496 \mathrm{C}+/-}$ versus WT mice.

Fig. 27 (A) Representative Western blots of important $\mathrm{Ca}^{2+}$ cycling proteins from cardiac homogenates prepared from hearts of CaMKII $\delta_{\mathrm{C}} / \mathrm{RyR} 2^{\mathrm{R} 4496 \mathrm{C}}$ and WT mice. (B) Quantification of the protein expression level in CaMKII $\delta_{\mathrm{C}} / \mathrm{RyR} 2^{\mathrm{R} 4496 \mathrm{C}}$ versus WT mice

Fig. $28 \mathrm{Ca}^{2+}$ sparks in mouse ventricular myocytes measured using Fluo-4 86

Fig. $29 \mathrm{Ca}^{2+}$ spark characteristics $\quad 87$

Fig. 30 Cellular arrhythmias recorded in electrically paced isolated ventricular 90 myocytes from RyR2 $2^{\mathrm{R} 4496 \mathrm{C}+/}$, CaMKII $\delta_{\mathrm{C}} / \mathrm{RyR} 2^{\mathrm{R} 4496 \mathrm{C}}$ and $\mathrm{CaMKII} \delta_{\mathrm{C}}$ mouse hearts 


\section{Abbreviations}

$\mathrm{Ab}$

AC3-I

Ad

AIP

AM

AMP

AP

APS

ATP

BCA

$\mathrm{BDM}$

bp

$\mathrm{CaM}$

CaMK

CaMKII

$\mathrm{CaMKII}_{\mathrm{C}}$

$\mathrm{CaMKII}_{\mathrm{C}} / \mathrm{RyR}^{\mathrm{R} 4496 \mathrm{C}}$

cAMP

$\mathrm{CaSpF}$

$\mathrm{Ci}$

CHAPS

CPVT

CSQ

DAD

dd $\mathrm{H}_{2} \mathrm{O}$

DEPC

DM

DMSO

DNA
Antibody

Autocamtide-2 inhibitory peptide

Adenovirus

Autocamtide- 2 related inhibitory peptide

acetoxymethyl ester

Adenosine monophosphate

Action potential

Ammonium persulfate

Adenosine triphosphate

Bicinchoninic acid

2,3-butanedione monoxime

Base pair

Calmodulin

$\mathrm{Ca}^{2+} /$ calmodulin-dependent protein kinase

$\mathrm{Ca}^{2+} /$ calmodulin-dependent protein kinase II

Cytosolic isoform of $\mathrm{Ca}^{2+} /$ calmodulin-dependent protein kinase II

Crossbred RyR2 ${ }^{\mathrm{R} 4496 \mathrm{C}+/}$ knock-in with CaMKII $\delta_{\mathrm{C}} \mathrm{TG}$ mice

Cyclic adenosine-3',5'-monophosphate

$\mathrm{Ca}^{2+}$ spark frequency

Curie

3-[(3-cholamidopropyl)dimethylammonio]-1-propane

sulphonate

Catecholaminergic polymorphic ventricular tachycardia

Calsequestrin

Delayed afterdepolarization

Double distilled water

Diethylpyrocarbonate

Double mutant

Dimethylsulfoxide

Desoxyribonucleic acid 
dNTP

DTT

EAD

E-C coupling

EDTA

EGTA

$\mathrm{E}_{\mathrm{m}}$

FDAR

FS

g

GAPDH

HA

HEK

HEPES

$\mathrm{HF}$

HPLC

HRP

$\mathrm{I}_{\mathrm{Ca}}$

ICC

IFM

$\mathrm{IgG}$

IP

$\mathrm{kDa}$

KN-93

LQT3

LQTS

MOI

NCX

PAAG

PBS

PCR

pfu

PKA
Deoxyribonucleoside triphosphate

Dithiothreitol

Early afterdepolarization

Excitation-contraction coupling

Ethylenedinitrilo-N, N, N', N'-tetraacetic acid

ethylene glycol tetraacetic acid

Membrane potential

Frequency-dependent acceleration of relaxation

Fractional shortening

Gravity

Glyceraldehyde-3-phosphate dehydrogenase

Hemagglutinin

Human embryonic kidney

2-(4-2-hydroxyethyl)-piperazinyl-1-ethansulfonate

Heart failure

High performance liquid chromatography

Horseradish peroxidase

Calcium current

Immunocytochemical staining

Isoleucine-phenylalanine-methionine

Immunoglobulin $\mathrm{G}$

Immunoprecipitation

Kilodalton

2-[N-(2-hydroxyethyl)-N-(4-methoxybenzenesulfonyl)] amino-N-(4-chlorocinnamyl)-N-methylbenzylamine

Long-QT syndrome 3

Long QT syndrome

Multiplicity of infection

$\mathrm{Na}^{+} / \mathrm{Ca}^{2+}$-exchanger

Polyacrylamide Gel

Phosphate buffered saline

Polymerase chain reaction

Plaque-forming unit

cAMP-dependent protein kinase 
PKC $\mathrm{Ca}^{2+}$-dependent protein kinase

PLB

Phospholamban

PLB-KO

PLB deficient mice

RyR

Ryanodine receptor

RyR2

Cardiac ryanodine receptor

RyR2 $2^{\mathrm{R} 4496 \mathrm{C}+/-}$

Knock-in mice harboring the R4496C mutation in RyR2

SCN5A

Human cardiac sodium channel

SDS

Sodium dodecylsulfate

SDS-PAGE

SDS-polyacrylamide gel electrophoresis

SEM

Standard error of the mean

SERCA2a

Cardiac sarcoplasmic reticulum $\mathrm{Ca}^{2+}$-ATPase

SR

Sarcoplasmic reticulum

TAC

Transverse aortic constriction

TBE

Tris-borate-EDTA buffer

TEMED

$\mathrm{N}, \mathrm{N}, \mathrm{N}^{\prime}, \mathrm{N}^{\prime}$-tetramethylethylenediamine

TG

Transgenic

Tris

Tris-(hydroxymethyl)-aminomethane

UV

Ultraviolet

VT

Ventricular tachyarrhythmias

WB

Western blot

WT

Wild type

$\beta$-gal

$\beta$-Galactosidase 


\section{Summary}

Intracellular calcium $\left(\mathrm{Ca}^{2+}\right)$ is a central second messenger, which translates the electrical signal into cardiac contraction. This process is termed excitation-contraction coupling (E-C coupling). Recently, it has become clear that several $\mathrm{Ca}^{2+}$-dependent proteins contribute to the fine tuning of E-C coupling. One of these is the $\mathrm{Ca}^{2+} /$ calmodulin-dependent protein kinase II (CaMKII). Its major cardiac isoform is CaMKII $\delta$ with the $\delta_{\mathrm{C}}$ splice variant being localized to the cytosol. CaMKII can phosphorylate and alter the function of several $\mathrm{Ca}^{2+}$ handling proteins including sarcoplasmic reticulum $\mathrm{Ca}^{2+}$ release channels also known as ryanodine receptors (RyR). Increased CaMKII activity has been linked to heart failure (HF) and ventricular arrhythmias. Expression levels and activity of CaMKII in human HF and in animal HF models are increased 2- to 3- fold. HF is associated with an increased risk of sudden death mainly caused by ventricular arrhythmias. Altered sodium $\left(\mathrm{Na}^{+}\right)$ channel function has been shown to underlie ventricular arrhythmias. Another mechanism for ventricular arrhythmias is catecholaminergic polymorphic ventricular tachycardia (CPVT). CPVT is a disease caused by mutations (e.g. R4497C) in the cardiac RyR2 gene in individuals with structurally normal hearts.

In the present work it has been investigated 1) whether $\mathrm{CaMKII} \delta_{\mathrm{C}}$ associates with and phosphorylates cardiac $\mathrm{Na}^{+}$channels in rabbit myocytes and mouse heart tissue thereby regulating its function possibly leading to ventricular arrhythmias; 2) intracellular $\mathrm{Ca}^{2+}$ handling in mouse myocytes harboring the R4496C mutation in RyR2; 3) possible alterations of E-C coupling and arrhythmogenic effects due to overexpression of CaMKII $\delta_{\mathrm{C}}$ in mouse hearts, carrying additionally the R4496C mutation in cardiac RyR2.

The present study shows that $\mathrm{CaMKII} \delta_{\mathrm{C}}$ associates with cardiac $\mathrm{Na}^{+}$channels within the transverse tubular system, and that $\mathrm{CaMKII} \delta_{\mathrm{C}}$ can phosphorylate $\mathrm{Na}^{+}$channels in both mouse and rabbit myocardium.

Studies with a mouse model harboring the R4496C mutation in RyR2 revealed abnormal $\mathrm{Ca}^{2+}$ release through RyR2. Overexpression of CaMKII $\delta_{\mathrm{C}}$ in these mice leads to severe heart failure, contractile dysfunction and altered intracellular $\mathrm{Ca}^{2+}$ handling in vitro causing arrhythmogenic events in isolated myocytes under basal conditions and increased mortality in vivo as compared to mice overexpressing $\mathrm{CaMKII} \delta_{\mathrm{C}}$ only. 


\section{Introduction}

\section{1 $\mathrm{Ca}^{2+}$ as a critical second messenger in cardiac myocytes}

Calcium $\left(\mathrm{Ca}^{2+}\right)$ is a critical second messenger in cardiac muscle. Elevated intracellular $\mathrm{Ca}^{2+}$ levels can activate numerous $\mathrm{Ca}^{2+}$-regulated enzymes, which have different subcellular localizations and may respond to distinct modes of $\mathrm{Ca}^{2+}$ mobilization. Intracellular cytosolic $\mathrm{Ca}^{2+}$ concentrations are regulated carefully to remain at $\sim 100 \mathrm{nM}$ under resting conditions. This occurs even when extracellular levels of $\mathrm{Ca}^{2+}$ are increased. Acute increases in intracellular $\mathrm{Ca}^{2+}$ are needed to elicit physiological responses in cells. In cardiac muscle, $\mathrm{Ca}^{2+}$ plays a central role in the regulation of contractility, hypertrophy, gene expression and apoptosis. Changes in intracellular $\mathrm{Ca}^{2+}$ generate both acute and chronic effects on cardiac function. The $\mathrm{Ca}^{2+}$ transients, which accompany each cardiac cycle, trigger cardiac muscle contraction, a process termed excitation-contraction (E-C) coupling that occurs on the millisecond time scale. The key amplification step in E-C coupling is under tight control of the strictly local $\mathrm{Ca}^{2+}$ concentration. In contrast, sustained or chronic (minutes to hours/days) alterations in $\mathrm{Ca}^{2+}$ signaling could result in activation of gene expression, the process known as excitation-transcription coupling. These pathways are involved in hypertrophy and heart failure, and they can alter the expression of some $\mathrm{Ca}^{2+}$ regulatory proteins involved in E-C coupling (Maier and Bers, 2002; Bers, 2001; Bers and Guo, 2005).

\subsection{Cardiac excitation-contraction coupling}

Upon myocyte membrane depolarization $\mathrm{Ca}^{2+}$ enters the cell mainly through voltage dependent L-type $\mathrm{Ca}^{2+}$ channels and triggers $\mathrm{Ca}^{2+}$ release from the sarcoplasmic reticulum (SR) via ryanodine receptors (RyR) to amplify $\mathrm{Ca}^{2+}$ current $\left(\mathrm{I}_{\mathrm{Ca}}\right)$, a process termed $\mathrm{Ca}^{2+}-$ induced $\mathrm{Ca}^{2+}$ release (Bers, 2002). The resultant rise in global intracellular $\mathrm{Ca}^{2+}$ causes $\mathrm{Ca}^{2+}$ binding to troponin $\mathrm{C}$, which in turn activates the myofilaments to produce cardiac contraction. To allow cardiac muscle to relax, cytosolic $\mathrm{Ca}^{2+}$ must be quickly removed. The main mechanisms for $\mathrm{Ca}^{2+}$ removal is mediated by SR $\mathrm{Ca}^{2+}$-ATPase (SERCA2a), which pumps $\mathrm{Ca}^{2+}$ back into SR, and by $\mathrm{Na}^{+} / \mathrm{Ca}^{2+}$-exchanger (NCX), which extrudes $\mathrm{Ca}^{2+}$ out of myocytes but may also contribute to systolic $\mathrm{Ca}^{2+}$ influx in its reverse mode (Bers, 2002). Quantitatively, during steady-state conditions, the same amount of $\mathrm{Ca}^{2+}$ that entered 
the cell upon activation via voltage dependent $\mathrm{L}$-type $\mathrm{Ca}^{2+}$ channels and reverse mode NCX is transported out of the cell, mainly via NCX, with a very minor contribution by the sarcolemmal $\mathrm{Ca}^{2+}$-ATPase. Likewise, the amount of $\mathrm{Ca}^{2+}$ previously released from the SR must be taken back up by SERCA2a. Of note, only a small $\mathrm{Ca}^{2+}$ flux (1-2\%) contributes to E-C coupling by the mitochondrial uniporter (Fig. 1)

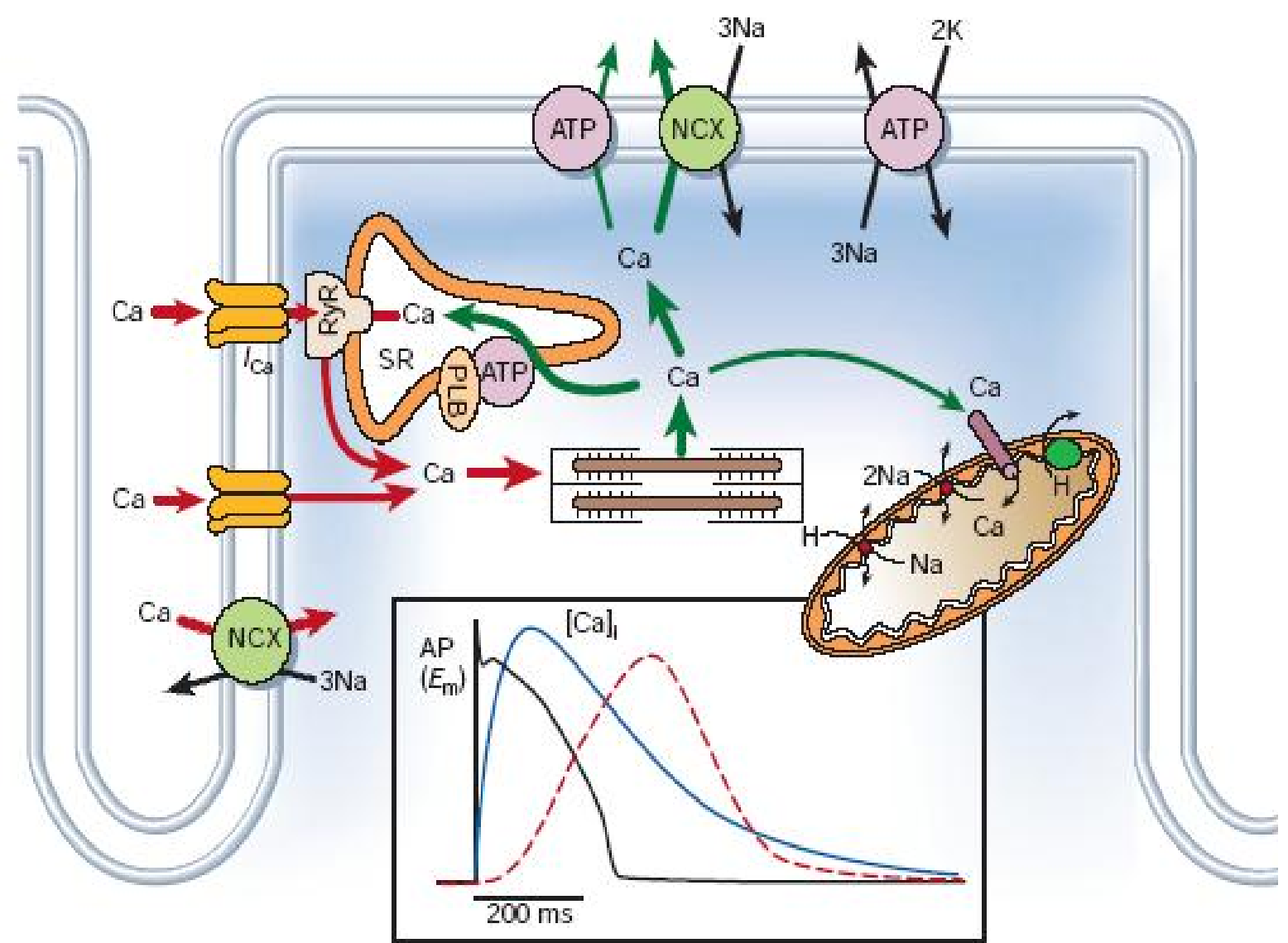

Figure 1. General scheme of $\mathrm{Ca}^{2+}$ cycle in a cardiac ventricular myocyte. $\mathrm{Ca}^{2+}$ can enter the cell via $\mathrm{Ca}^{2+}$ channels $\left(\mathrm{I}_{\mathrm{Ca}}\right.$ ) and $\mathrm{Na}^{+} / \mathrm{Ca}^{2+}$ exchange $(\mathrm{NCX}) . \mathrm{Ca}^{2+}$ influx controls $\mathrm{SR} \mathrm{Ca}^{2+}$ release by the ryanodine receptor (RyR). $\mathrm{Ca}^{2+}$ is removed from cytosol by the SR $\mathrm{Ca}^{2+}$-ATPase pump (ATP), modulated by phospholamban (PLB), NCX and only to a minor extent by sarcolemmal $\mathrm{Ca}^{2+}$ ATPase pump and mitochondrial uniporter (from Bers, 2002).

This well coordinated process of E-C coupling occurring at approximately 60 times per minute in man and up to 500 times per minute in mouse during rest, consists of thousands of synchronized local events. About 25 L-type $\mathrm{Ca}^{2+}$ channel proteins and $100 \mathrm{RyR} 2$ proteins are co-localized in the junctional microdomain between the SR and the 
sarcolemmal membrane forming a local $\mathrm{SR} \mathrm{Ca}^{2+}$ release unit called junction or couplon (Bers and Guo, 2005). Spontaneous $\mathrm{Ca}^{2+}$ releases from an individual couplon $\left(\mathrm{Ca}^{2+}\right.$ sparks) during diastole in cardiac myocytes can be monitored by confocal microscopy. $\mathrm{Ca}^{2+}$ influx through $\mathrm{I}_{\mathrm{Ca}}$ raises local intracellular $\mathrm{Ca}^{2+}$ from 0.1 to $>10 \mu \mathrm{M}$, and local $\mathrm{Ca}^{2+}$ release from a cluster of RyR2s further increases local cleft $\mathrm{Ca}^{2+}$ to $>100 \mu \mathrm{M}$, whereas global intracellular $\mathrm{Ca}^{2+}$ only reaches $\sim 1 \mu \mathrm{M}$ (at a later time). A critical aspect of this discrete local signaling is that as local intracellular $\mathrm{Ca}^{2+}$ declines between junctions, it is not sufficient to trigger $\mathrm{SR} \mathrm{Ca}^{2+}$ release at neighboring junctions 1-2 $\mu \mathrm{m}$ away (Bers, 2002). However, physiologically these local SR $\mathrm{Ca}^{2+}$ release events are synchronized by action potentials and simultaneous activation of $\mathrm{I}_{\mathrm{Ca}}$ at all junctions to produce a relatively homogenous increase in intracellular $\mathrm{Ca}^{2+}$ throughout the cytosol. Therefore, $\mathrm{Ca}^{2+}$ sparks are the elementary units of SR release both at rest and during the normal $\mathrm{Ca}^{2+}$ transient during E-C coupling (Bers, 2002; Cheng et al., 1993; Fill and Copello, 2002).

\subsection{Modulation of $\mathrm{E}-\mathrm{C}$ coupling via $\mathrm{Ca}^{2+} /$ calmodulin-dependent protein kinase II}

There is considerable evidence that changes in intracellular $\mathrm{Ca}^{2+}$ handling are not only involved in the direct myofilament activation leading to contraction, but also indirectly modify the activity of ion channels and transporters via calmodulin (CaM) and $\mathrm{Ca}^{2+} /$ calmodulin-dependent protein kinase II (CaMKII) (Maier and Bers, 2002). CaM is an important signaling messenger in nearly all cell types, where $\mathrm{Ca}^{2+} / \mathrm{CaM}$ regulates proteins involved in $\mathrm{Ca}^{2+}$ transport, ion channels, cell contraction, protein kinases, cell metabolism, gene expression and cell proliferation (Cheung, 1980; Vogel, 1994). $\mathrm{Ca}^{2+} /$ calmodulindependent protein kinases (CaMKs) are one of the targets for $\mathrm{CaM}$ binding. This multifunctional serine/threonine family consists of CaMKI, -II, and -IV and has a wide tissue distribution. CaMKI and CaMKIV are monomeric enzymes that are activated by phosphorylation through an upstream kinase (Lee and Edelman, 1994; Tokumitsu et al., 1995). These isoforms are expressed at very low levels in the heart (Edman and Schulman, 1994; Colomer et al., 2003). In contrast, CaMKII is a multimer of 6-12 subunits encoded by four separate genes: $\alpha, \beta, \gamma$, and $\delta$ (Braun and Schulman, 1995). Binding of $\mathrm{Ca}^{2+} / \mathrm{CaM}$ to CaMKII leads to its activation and subsequent autophosphorylation, rendering it capable of autoactivation in the absence of $\mathrm{Ca}^{2+} / \mathrm{CaM}$ (Braun and Schulman, 1995). CaMKII can 
modulate E-C coupling by phosphorylating several important $\mathrm{Ca}^{2+}$ transport proteins in the heart in response to $\mathrm{Ca}^{2+}$ signals, including RyR2 (Witcher et al., 1991; Hain et al., 1995), PLB (Davis et al., 1983; Simmerman et al., 1986) and L-type $\mathrm{Ca}^{2+}$ channels (Maier and Bers, 2002) with multiple functional consequences (Fig. 2)

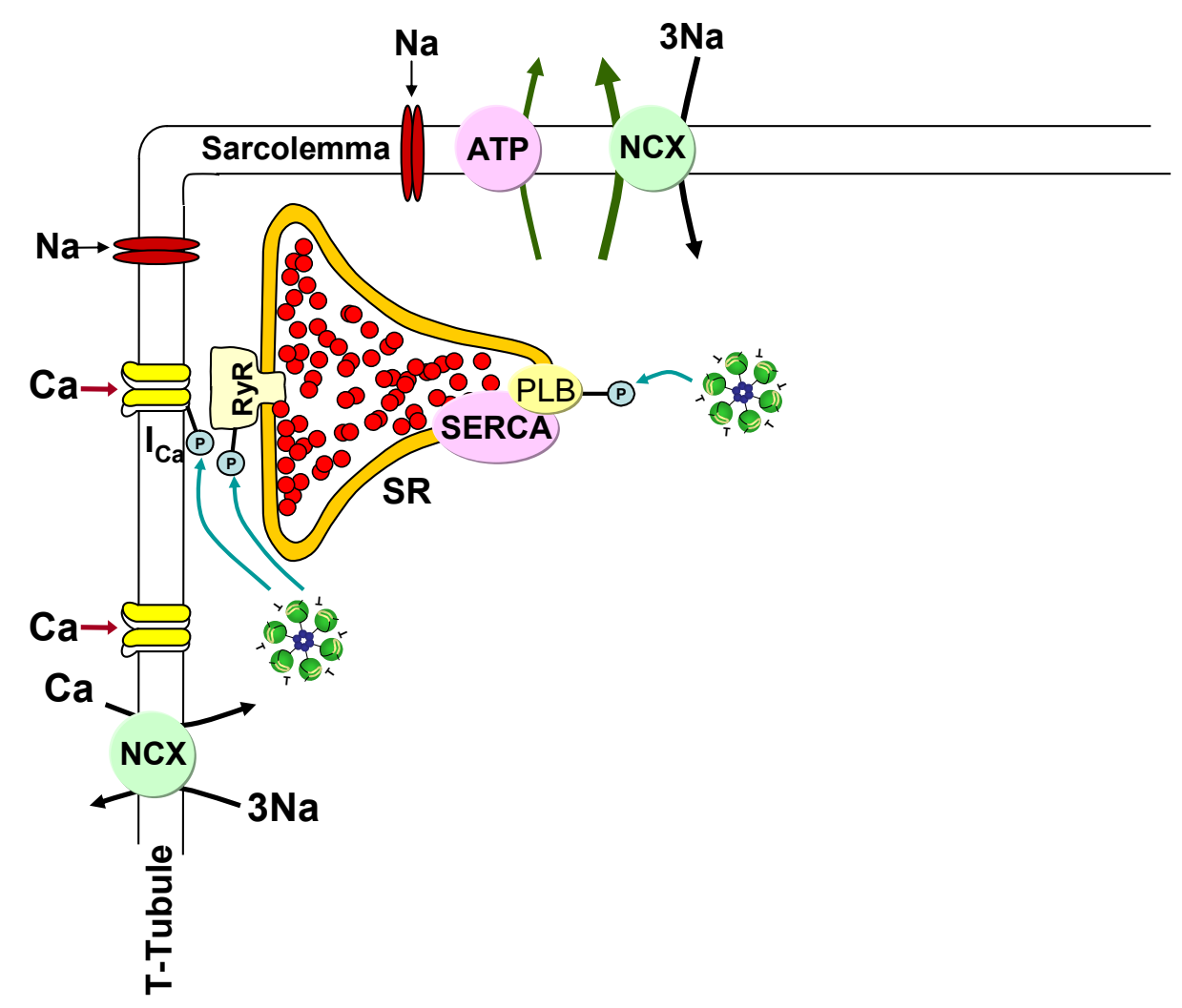

Figure 2. Effects of CaMKII $\delta_{C}$ on excitation-contraction coupling. CaMKII phosphorylates several $\mathrm{Ca}^{2+}$-handling proteins including phospholamban (PLB), SR $\mathrm{Ca}^{2+}$ release channels (RyR), and L-type $\mathrm{Ca}^{2+}$ channels responsible for $\mathrm{Ca}^{2+}$ influx $\left(\mathrm{I}_{\mathrm{Ca}}\right)$ (modified from Maier and Bers, 2007).

\subsubsection{Structure of $\mathrm{Ca}^{2+} /$ calmodulin-dependent protein kinase II}

The multimeric CaMKII holoenzyme consists of homo- or heteromultimers of 6-12 kinase subunits forming a wheel-like structure (Maier and Bers, 2002; Hook and Means, 2001) (Fig. 3). There are four closely related but different CaMKII genes ( $\alpha, \beta, \gamma$ and $\delta$ ). The $\alpha$ and $\beta$ isoforms are expressed in the nervous tissue, whereas the $\gamma$ and $\delta$ isoforms are more ubiquitous. The $\delta$ isoform is the predominant isoform of CaMKII in the heart. There are two splice variants of the $\delta$ isoform: $\delta_{\mathrm{B}}$ is localized to the nucleus, whereas $\delta_{\mathrm{C}}$ is found in cytoplasm. Each CaMKII subunit has three structural domains: an amino-terminal catalytic 
domain, a central regulatory domain (containing partially overlapping autoinhibitory and $\mathrm{CaM}$ binding regions) and a carboxy-terminal association domain responsible for oligomerization (Braun and Schulman, 1995; Maier and Bers, 2002). Resting CaMKII is blocked by the autoinhibitory region that acts as a pseudosubstrate, preventing a substrate from binding. When intracellular $\mathrm{Ca}^{2+}$ increases, such as during systole, $\mathrm{Ca}^{2+} / \mathrm{CaM}$ complex binds to the regulatory domain of CaMKII and displaces the autoinhibitory domain by wrapping itself around it resulting in release of the active centre of the catalytic region, which then gains access to substrates. After this $\mathrm{Ca}^{2+} / \mathrm{CaM}$-dependent activation, CaMKII locks itself into the activated state by autophosphorylation of Thr-286 on the autoinhibitory segment of adjacent CaMKII subunits (Braun and Schulman, 1995; Zhang and Brown, 2004).
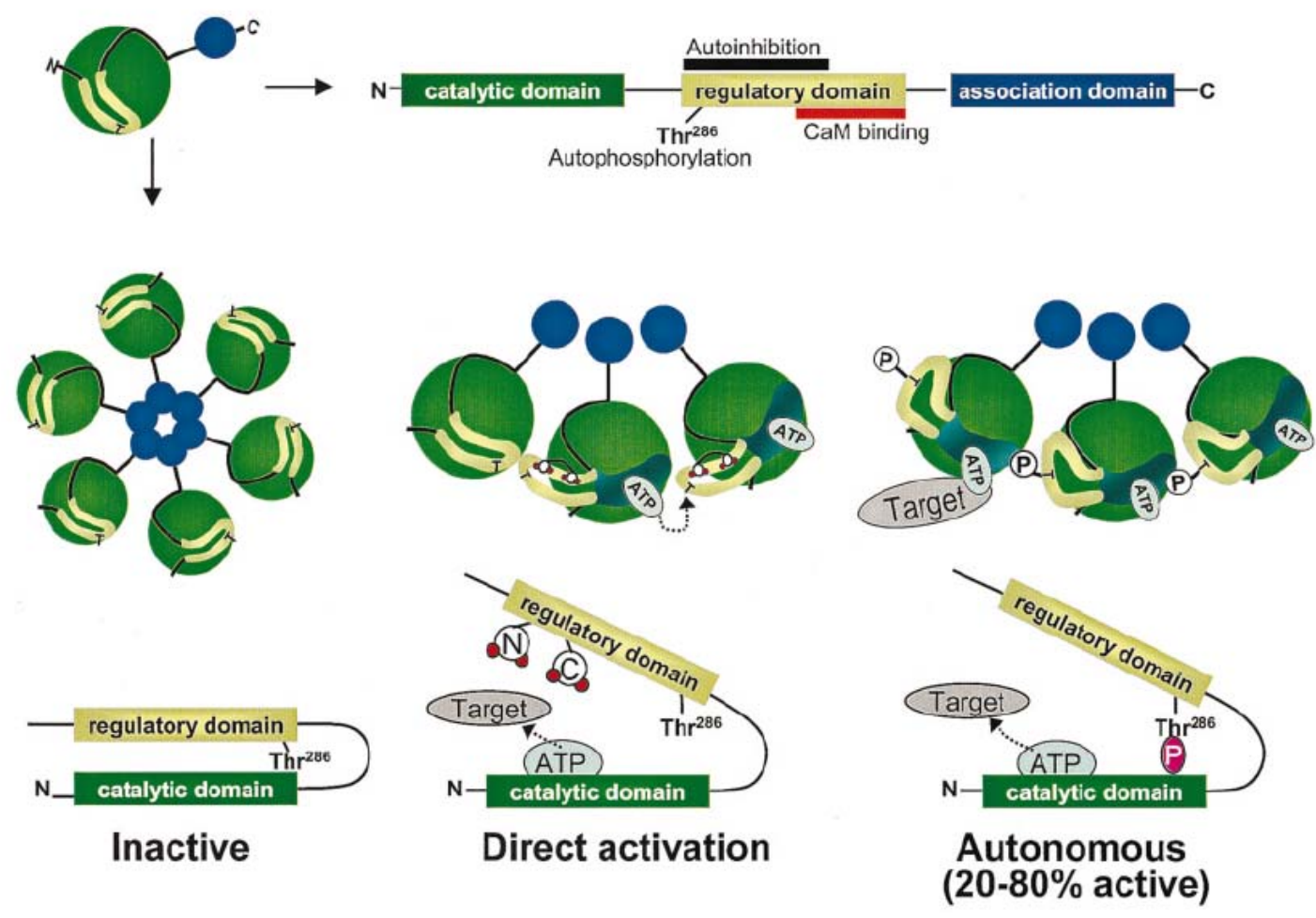

Figure 3. Domain layout and oligomeric organization of CaMKII. The three main domains of the CaMKII monomer are indicated in a linear layout (top). Middle left shows that CaMKII forms homo- or heteromultimers (6-12 monomers) in wheel-like structures (a second one may sit on top of the one shown, forming a double wheel). Lower middle and right panels show activation of CaMKII by $\mathrm{Ca}^{2+} / \mathrm{CaM}$ binding and subsequent autophosphorylation at Thr-286 (P). CaM binding is sufficient to activate CaMKII allowing the active site (ATP) to interact and phosphorylate target proteins. Autophosphorylation maintains CaMKII active (20-80\%) even after CaM dissociation (from Maier and Bers, 2002). 
Autophosphorylation at Thr-286 in the autoinhibitory domain can maintain CaMKII active even after $\mathrm{Ca}^{2+}$ has declined, (e.g. during diastole) when $\mathrm{Ca}^{2+} / \mathrm{CaM}$ has dissociated from its binding region, and will generate autonomous activity of CaMKII. Autophosphorylation is not essential for CaMKII activity, but it does have important consequences, i.e. by increasing the affinity of the $\mathrm{Ca}^{2+} / \mathrm{CaM}$-kinase complex (Meyer et al., 1992). This effect traps $\mathrm{Ca}^{2+} / \mathrm{CaM}$ on the autophosphorylated subunit. Even after declining $\mathrm{Ca}^{2+}$ to resting levels during diastole (i. e. $\sim 100 \mathrm{nM}$ ), CaM is still trapped on the kinase for several seconds. As a result, the kinase retains fully active with $\mathrm{CaM}$ bound regardless of the $\mathrm{Ca}^{2+}$ level and partially active (20-80\%) after CaM dissociation from this autonomous state (Meyer et al., 1992; Lai et al., 1986; Lou et al., 1986).

\subsubsection{Phosphorylation of L-type Ca ${ }^{2+}$ channels by CaMKII results in $\mathrm{Ca}^{2+}$ - dependent $I_{C a}$ facilitation}

CaMKII modulates voltage-gated L-type $\mathrm{Ca}^{2+}$ channel and results in $\mathrm{Ca}^{2+}$-dependent $\mathrm{I}_{\mathrm{Ca}}$ facilitation, which is typically observed as increased $\mathrm{I}_{\mathrm{Ca}}$ amplitude and slower inactivation over 2 to 5 pulses. Several groups demonstrated that $\mathrm{Ca}^{2+}$-dependent $\mathrm{I}_{\mathrm{Ca}}$ facilitation is regulated by CaMKII-dependent phosphorylation (Anderson et al., 1994; Xiao et al., 1994; Yuan and Bers, 1994). CaMKII can bind to the $\alpha_{1 \mathrm{C}}$ subunit of the cardiac L-type $\mathrm{Ca}^{2+}$ channel and can phosphorylate the $\alpha_{1 \mathrm{C}}$ subunit at carboxy tails (Hudmon et al., 2005). CaMKII also phosphorylates Thr-498 on the $\beta_{2 \mathrm{a}}$-subunit of the L-type $\mathrm{Ca}^{2+}$ channel, which may be involved in the functional effect of $I_{C a}$ facilitation (Grueter et al., 2006). At the single channel level this CaMKII-dependent $\mathrm{I}_{\mathrm{Ca}}$ facilitation is manifested as longer single channel opening (Dzhura et al., 2000). This $\mathrm{I}_{\mathrm{Ca}}$ facilitation is $\mathrm{Ca}^{2+}$-dependent and CaMKIIdependent, because it could be abolished by a CaMKII inhibitory peptide and is not apparent with $\mathrm{Ba}^{2+}$ as the charge carrier. $\mathrm{I}_{\mathrm{Ca}}$ facilitation is also a local event because it is still observed when the intracellular milieu of a cell is heavily $\mathrm{Ca}^{2+}$ buffered with $10 \mathrm{mM}$ EGTA. The physiological role of $\mathrm{I}_{\mathrm{Ca}}$ facilitation is not entirely clear, but it may partly offset reduced L-type $\mathrm{Ca}^{2+}$ channel availability at high heart rates (caused by direct $\mathrm{Ca}^{2+}$ dependent inactivation). By overexpressing $\mathrm{CaMKII} \delta_{\mathrm{C}}$ in transgenic mouse myocytes as well as in adenovirus-mediated rabbit myocytes, $\mathrm{I}_{\mathrm{Ca}}$ amplitude was increased and inactivation was slowed (Maier et al., 2003, Kohlhaas et al., 2006). $\mathrm{I}_{\mathrm{Ca}}$ amplitude could be reduced back to control levels by blocking CaMKII with the organic inhibitor KN-93 
(Maier et al., 2003) or with the autocamtide-2 related inhibitory peptide (AIP) (Kohlhaas et al., 2006).

\subsubsection{Enhancement of SERCA2a activity and SR $\mathrm{Ca}^{2+}$ uptake upon PLB phosphorylation by CaMKII}

$\mathrm{Ca}^{2+}$ uptake into the SR is mediated by SERCA2a, which plays an important role in the declining phase of the $\mathrm{Ca}^{2+}$ transient. The activity of SERCA2a, the isoform expressed in the heart, is regulated by intracellular $\mathrm{Ca}^{2+}$ concentration and PLB. PLB is an endogenous inhibitor of SERCA2a in its unphosphorylated state (Brittsan and Kranias, 2000). PLB can be phosphorylated by cAMP-dependent protein kinase (PKA) at Ser-16 and by CaMKII at Thr-17 (Brittsan and Kranias, 2000, Simmerman et al., 1986). Bassani and colleagues (Bassani et al., 1995) demonstrated that CaMKII enhanced SR $\mathrm{Ca}^{2+}$ uptake, and suggested that CaMKII phosphorylation of PLB might be responsible for the frequency-dependent acceleration of relaxation (FDAR) of twitches and $\mathrm{SR} \mathrm{Ca}^{2+}$ uptake. Some studies even showed that direct CaMKII-dependent SERCA2a phosphorylation stimulates its activity, although others failed to show the significant stimulatory function of CaMKII on SERCA2a (Maier and Bers, 2002). Hagemann and colleagues (Hagemann et al., 2000) showed a frequency-dependent increase in PLB Thr-17 phosphorylation in rat myocytes in the absence of Ser-16 phosphorylation, and that the level of CaMKII phosphorylation of PLB at Thr-17 correlated with the rate of relaxation.

Physiologically, FDAR could be an important intrinsic mechanism to allow faster relaxation when heart rate is increased. It has been hypothesized that FDAR might be due to enhanced SR $\mathrm{Ca}^{2+}$ uptake via PLB phosphorylation by CaMKII, activated by the cyclic increase in $\mathrm{Ca}^{2+}$ during E-C coupling. However, it was found that FDAR is still quite prominent in PLB deficient (PLB-KO) mice and still sensitive to CaMKII inhibition by KN-93 and AIP (DeSantiago et al., 2002). Thus, while PLB might contribute to FDAR, it cannot be the sole mechanism.

\subsubsection{Regulation of RyR2 channel by CaMKII}

CaMKII also affects RyR2 activity. Witcher and colleagues (Witcher et al., 1991) first reported that the unique phosphorylation site was Ser-2809 on RyR2 which regulated channel activity. Later Rodriguez and colleagues (Rodriguez et al., 2003) suggested that CaMKII may phosphorylate at least four sites in addition to Ser-2809. Wehrens and 
colleagues (Wehrens et al., 2004) identified a CaMKII phosphorylation site on RyR2 at Ser-2815 using site-directed mutagenesis. Other studies also showed that RyR2 is a substrate of CaMKII (Hain et al., 1995; Lokuta et al., 1997), but the real functional effect of phosphorylation by CaMKII in vivo is still unclear and controversial. That is, CaMKII was suggested to either increase (Hain et al., 1995; Witcher et al., 1991) or decrease the RyR2 open probability (Lokuta et al., 1997). Most studies on CaMKII effects on RyR2 have been conducted using RyR2 in lipid bilayers or by measuring $\mathrm{Ca}^{2+}$ release from SR vesicles. It is important to study RyR2 behavior in its native cellular environment. In intact voltage clamped ventricular myocytes endogenous CaMKII increased the amount of SR $\mathrm{Ca}^{2+}$ release for a given SR $\mathrm{Ca}^{2+}$ content and $\mathrm{I}_{\mathrm{Ca}}$ triggers (Li et al., 1997). This effect of CaMKII on RyR2 was evaluated when both L-type $\mathrm{Ca}^{2+}$ current and $\mathrm{SR} \mathrm{Ca}^{2+}$ load were constant under control conditions and in the presence of the CaMKII inhibitor KN-93. However, $\mathrm{Wu}$ and colleagues (Wu et al., 2001) showed that constitutively active CaMKII inhibited $\mathrm{Ca}^{2+}$ transients, while a CaMKII inhibitor increased $\mathrm{Ca}^{2+}$ transients. Yang and colleagues (Yang et al., 2007) reported that phosphorylation of RyR2 by CaMKII negatively regulates $\mathrm{Ca}^{2+}$ spark and $\mathrm{Ca}^{2+}$ wave activities, thus serving as a stabilizing factor for $\mathrm{SR} \mathrm{Ca}^{2+}$ release in intact cardiac myocytes.

Recent studies performed in isolated cardiac myocytes have provided new evidences indicating that CaMKII indeed is directly associated with RyR2 (Zhang et al., 2003; Wehrens et al., 2004; Currie et al., 2004) and overexpression of CaMKII increases fractional $\mathrm{SR} \mathrm{Ca}^{2+}$ release as well as resting spontaneous SR $\mathrm{Ca}^{2+}$ spark frequency despite lower SR $\mathrm{Ca}^{2+}$ load and diastolic $\mathrm{Ca}^{2+}$ (Maier et al., 2003; Kohlhaas et al., 2006; Guo et al., 2006). In addition to this increased frequency (which is indicative of RyR2-mediated diastolic spontaneous $\mathrm{SR} \mathrm{Ca}^{2+}$ sparks), width and duration of $\mathrm{Ca}^{2+}$ sparks were enhanced, demonstrating increased diastolic $\mathrm{SR} \mathrm{Ca}^{2+}$ leak. In contrast, $\mathrm{Ca}^{2+}$ spark frequency decreases dramatically upon inhibition of CaMKII by KN-93 (Maier et al., 2003). These results in myocytes from CaMKIII $\delta_{C}$ transgenic mouse hearts have been recently confirmed by acute $\mathrm{CaMKII} \delta_{\mathrm{C}}$ overexpression by adenovirus-mediated gene transfer in isolated rabbit myocytes (Kohlhaas et al., 2006) as well as direct application of preactivated CaMKII to permeabilized mouse myocytes (Guo et al., 2006). In rabbit hearts, AIP (CaMKII inhibitor peptide) decreased $\mathrm{Ca}^{2+}$ spark frequency, indicating that CaMKII activates RyR2 in myocytes (Currie et al., 2004). Wehrens and colleagues (Wehrens et al., 2004) also showed that CaMKII-dependent RyR2 phosphorylation increases the RyR2 open probability using 
channel measurements in lipid bilayers. Taken together, CaMKII-dependent RyR2 phosphorylation seems to have strong stimulatory effects on RyR2 activity in vivo.

\subsection{Role of CaMKII in the development of heart failure}

As was discussed, CaMKII can phosphorylate and alter the function of several $\mathrm{Ca}^{2+}$ transport proteins and plays an important role in E-C coupling in cardiomyocytes. CaMKII is also associated with the development of hypertrophy and heart failure (HF). Heart failure is characterized by contractile dysfunction of the heart developing with hypertrophy and which is associated with changes in cardiomyocyte $\mathrm{Ca}^{2+}$ homeostasis. It has been reported that CaMKII expression and activity are increased 2- to 3-fold in patients with heart failure due to dilated cardiomyopathy. Initially, it was hypothesized that upregulation and activation of CaMKII might represent a compensatory mechanism to keep diseased hearts from contractile failure (Hoch et al., 1999; Kirchhefer et al., 1999). However, several transgenic (TG) mouse models have established a role for CaMK in the development of cardiac hypertrophy.

Overexpression of CaMKII $\delta_{\mathrm{B}}$, which is highly concentrated in cardiomyocyte nuclei, causes transcriptional activation of atrial natriuretic factor gene expression (a hypertrophic signaling marker) in neonatal rat ventricular myocytes (Ramirez et al., 1997). Similarly, transgenic mice that overexpress $\mathrm{CaMKII} \delta_{\mathrm{B}}$ induce cardiac hypertrophy and mild ventricular dilation (Zhang et al., 2002). CaMKIV, which is physiologically expressed at very low levels in the heart (Maier and Bers, 2002; Zhang and Brown, 2004), was also shown to contribute to the development of cardiac hypertrophy upon its overexpression in transgenic mice (Passier et al., 2000). Pressure overload hypertrophy induced by transverse aortic constriction (TAC) surgery in mouse hearts results in a rapid increase of CaMKII expression and activity (Zhang et al., 2003; Saito et al., 2003). It was hypothesized that the nuclear isoform $\mathrm{CaMKII} \delta_{\mathrm{B}}$ serves as a compensatory mechanism by initiating hypertrophic gene expression, while the cytoplasmic isoform CaMKII $\delta_{\mathrm{C}}$ serves as a compensatory mechanism by improving $\mathrm{Ca}^{2+}$ handling. At an early stage of hypertrophy, these changes could be beneficial to the maintenance of normal cardiac function. However, at later stages, when $\mathrm{CaMKII} \delta_{\mathrm{C}}$ expression is upregulated and alteration in $\mathrm{Ca}^{2+}$ handling are sustained, CaMKII might contribute to the downward spiral leading to heart failure. Overexpression of the cytoplasmic isoform CaMKII $\delta_{\mathrm{C}}$ in mouse hearts clearly results in 
severe contractile dysfunction and heart failure (Zhang et al., 2003; Maier et al., 2003) (Fig. 4). In these animals alterations in intracellular $\mathrm{Ca}^{2+}$ handling were observed with a marked reduction in $\mathrm{Ca}^{2+}$ transients, SR $\mathrm{Ca}^{2+}$ content, and SERCA2a, PLB, and RyR2 protein expression and enhanced NCX function and expression, all of which are widely accepted as indicative for heart failure. In contrast RyR2 phosphorylation increases in CaMKII $\delta_{\mathrm{C}}$ versus wild type mouse hearts and appears to be responsible for the development of increased SR $\mathrm{Ca}^{2+}$ spark frequency despite reduced $\mathrm{SR} \mathrm{Ca}^{2+}$ load and diastolic $\mathrm{Ca}^{2+}$, which by themselves would normally reduce $\mathrm{SR} \mathrm{Ca}^{2+}$ leak (Fig.5). This increased RyR2 phosphorylation most likely results directly from CaMKII $\delta_{\mathrm{C}}$ overexpression, because $\mathrm{Ca}^{2+}$ spark frequency could be reduced back to normal levels by blocking CaMKII (Maier et al., 2003, Zhang et al., 2003).

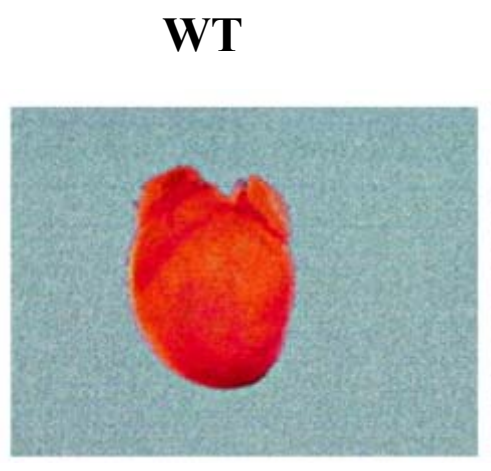

TG 6 weeks old

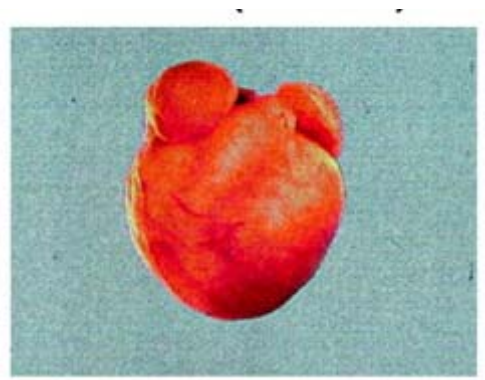

TG 13 weeks old

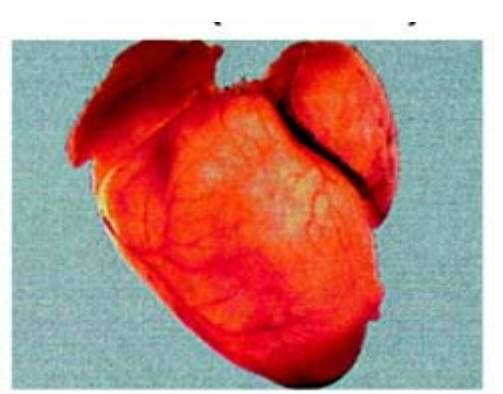

Figure 4. Cardiac pathology in CaMKII $\delta_{C}$ TG mice. Images of the whole hearts from WT and TG mice aged 6 and 13 weeks (from Zhang et al, 2003).

\subsection{Involvement of CaMKII in cardiac arrhythmias}

Cardiac arrhythmias are a leading cause of death in patients with heart failure. Arrhythmia mechanisms in cardiomyopathy involve cellular remodeling. Cellular studies reveal an action potential (AP) duration prolongation and an increased propensity for afterdepolarizations that are important mechanisms for triggering arrhythmias (Zeng and Rudy, 1995; Priebe and Beuckelmann, 1998). These triggers are due to the increased net inward current and could occur as early afterdepolarizations (EAD) or delayed afterdepolarizations (DAD). EAD are named so because they occur early relative to the completion of action potential repolarization. EAD occur during the action potential 


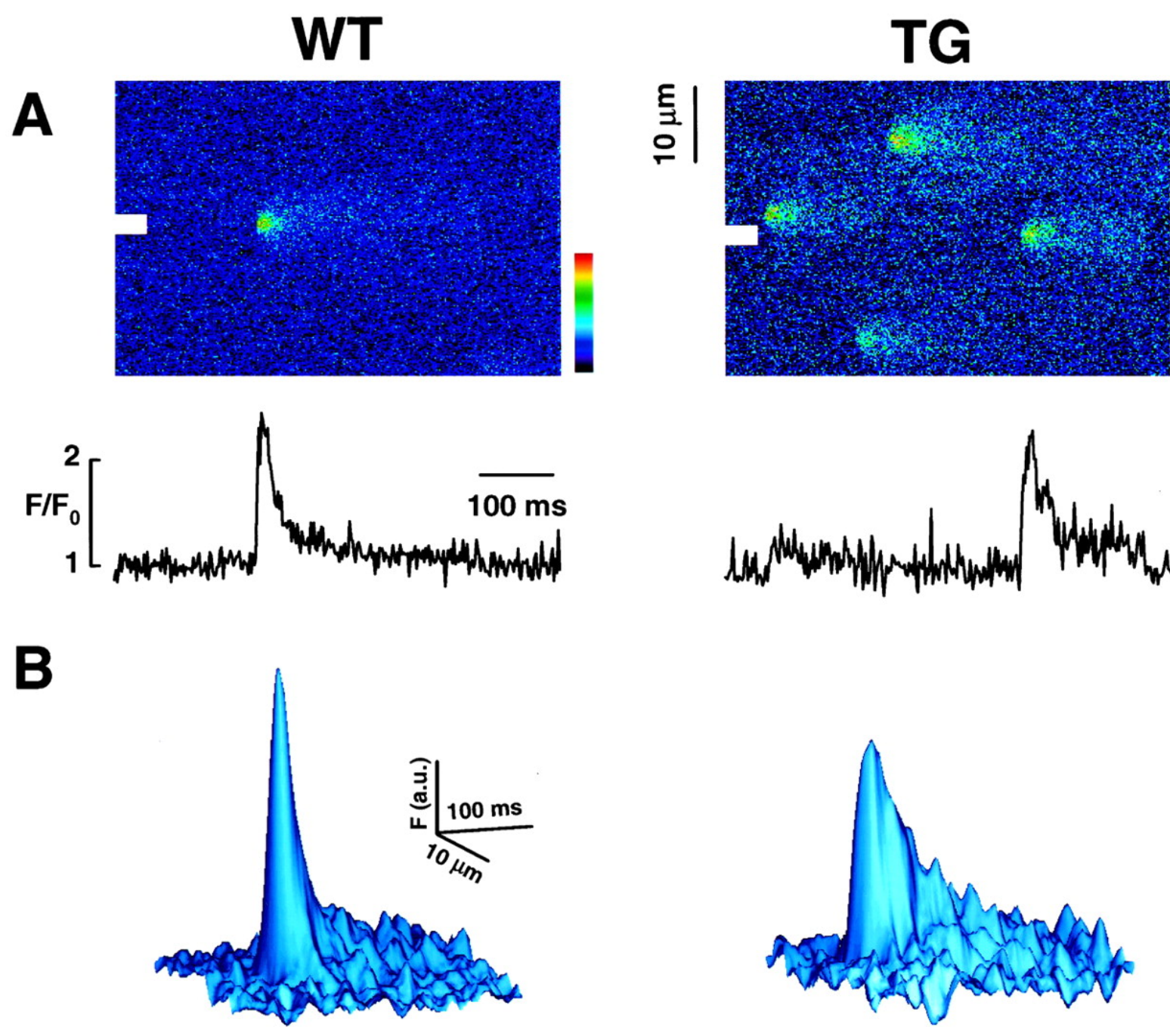

Figure 5. Representative $\mathrm{Ca}^{2+}$ sparks in CaMKII $\delta_{\mathrm{C}}$ TG versus WT mice. (A) Representative longitudinal line scan images, with line plots of $\mathrm{Ca}^{2+}$ at sites indicated by white bars. (B) 3-D surface plot of signal averaged $\mathrm{Ca}^{2+}$ sparks from the cells in A (from Maier et al., 2003).

plateau or phase II and III repolarization and are more likely during long action potential durations, long QT syndrome (LQTS), bradycardia, and are most often associated with repetitive L-type $\mathrm{Ca}^{2+}$ channel openings (January and Riddle, 1989). EAD were suggested to initiate long QT- arrhythmias. Anderson and colleagues (Anderson et al., 1998) first reported that CaMKII is involved in the development of EAD and arrhythmias as a consequence of L-type $\mathrm{Ca}^{2+}$ channel activation. They showed that EAD in isolated rabbit hearts were associated with an enhanced CaMK activity, and depended on the L-type $\mathrm{Ca}^{2+}$ current. EAD can be suppressed by KN-93, the CaMKII inhibitor. Studies using rabbit ventricular myocytes demonstrated that L-type $\mathrm{Ca}^{2+}$ current is augmented by a mechanism 
involving the release of SR $\mathrm{Ca}^{2+}$ and the activation of CaMKII. The CaMKII inhibitory peptide AC3-I prevents afterdepolarizations and normalizes L-type $\mathrm{Ca}^{2+}$ channel opening (Wu et al, 1999). In another study, the same group developed a mouse model of cardiac hypertrophy using transgenic expression of CaMKIV. These mice show also a significantly increased CaMKII activity and expression as a side effect and suffer from increased arrhythmias, which could be increased by isoprotenerol and decreased by KN-93 or a specific inhibiting peptide for CaMKII (AC3-I). CaMKIV TG mice showed also increased QT-intervals and prolonged action potential durations leading to EAD (Wu et al, 2002). In summary, these studies show that the increased CaMK activation is proarrhythmic during an action potential prolongation (Anderson et al., 1998; Wu et al, 1999, Wu et al, 2002).

Delayed afterdepolarizations owe their name to their occurrence after repolarization of the action potential to baseline. These afterdepolarization are widely accepted as being caused by spontaneous SR $\mathrm{Ca}^{2+}$ release events that occur during SR $\mathrm{Ca}^{2+}$ overload. This SR $\mathrm{Ca}^{2+}$ release causes a transient inward current that can alter the surface membrane potential and generate DAD. The latter in turn can lead to aftercontractions and triggered arrhythmias. CaMKII acts at key sites for $\mathrm{Ca}^{2+}$ homeostasis and increases L-type $\mathrm{Ca}^{2+}$ current as well as enhances the uptake and release of $\mathrm{Ca}^{2+}$ from the SR in ventricular myocytes. Thus, CaMKII activity could be important for the development of $\mathrm{Ca}^{2+}$ overload-dependent arrhythmias. Zhang and colleagues (Zhang et al., 2005) demonstrated a reduced sarcoplasmic reticulum $\mathrm{Ca}^{2+}$ content in a genetic mouse model of cardiac CaMKII inhibition (AC3-I) which results from diminished sarcoplasmic reticulum $\mathrm{Ca}^{2+}$ uptake, related to the reduced PLB phosphorylation by CaMKII. This reduction in sarcoplasmic reticulum $\mathrm{Ca}^{2+}$ content in AC3-I hearts was linked to a reduction in CaMKII activity rather than altered expression of sarcoplasmic reticulum proteins. Wu and colleagues (Wu et al., 1999) showed that elevated intracellular $\mathrm{Ca}^{2+}$ concentrations can activate transient inward current due to $\mathrm{Na}^{+} / \mathrm{Ca}^{2+}$ exchanger activity in isolated ventricular rabbit myocytes and inhibition of CaMKII completely suppresses this transient inward current. These results show that CaMKII can enhance EAD as well as DAD and link these afterdepolarizations to arrhythmias.

However, not only heart failure can lead to arrhythmias. Rare genetic mutations in $\mathrm{Na}^{+}$ channels and RyR2 in patients with structurally normal hearts can increase the risk for arrhythmias and will be discussed below. 


\subsection{Cardiac voltage-gated $\mathrm{Na}^{+}$channels}

\subsubsection{The structure and function of $\mathrm{Na}^{+}$channels}

Voltage-gated $\mathrm{Na}^{+}$channels are large membrane glycoproteins with a molecular mass of $\sim 260 \mathrm{kDa}$. They are composed of a pore-forming $\alpha$ subunit and auxiliary $\beta$ subunits (Catterall 2000). The $\alpha$ subunit is the major subunit of the channel essential for its function. Different isoforms of $\alpha$ subunits of $\mathrm{Na}^{+}$channels have distinct distribution with the $\mathrm{Na}_{\mathrm{v}} 1.5$ (SCN5A) isoform being the predominant isoform in the heart (Fig 6). The auxiliary $\beta$ subunits modulate channel gating, interact with extracellular matrix, and function as cell adhesion molecules (Isom et al., 1994; Isom, 2001). The cardiac $\alpha$ subunit consists of four homologous domains (I-IV). Each domain has six transmembrane segments of 19-27 amino acids (S1-S6). The fourth transmembrane segment (S4) of each domain is highly

\section{Na channel}

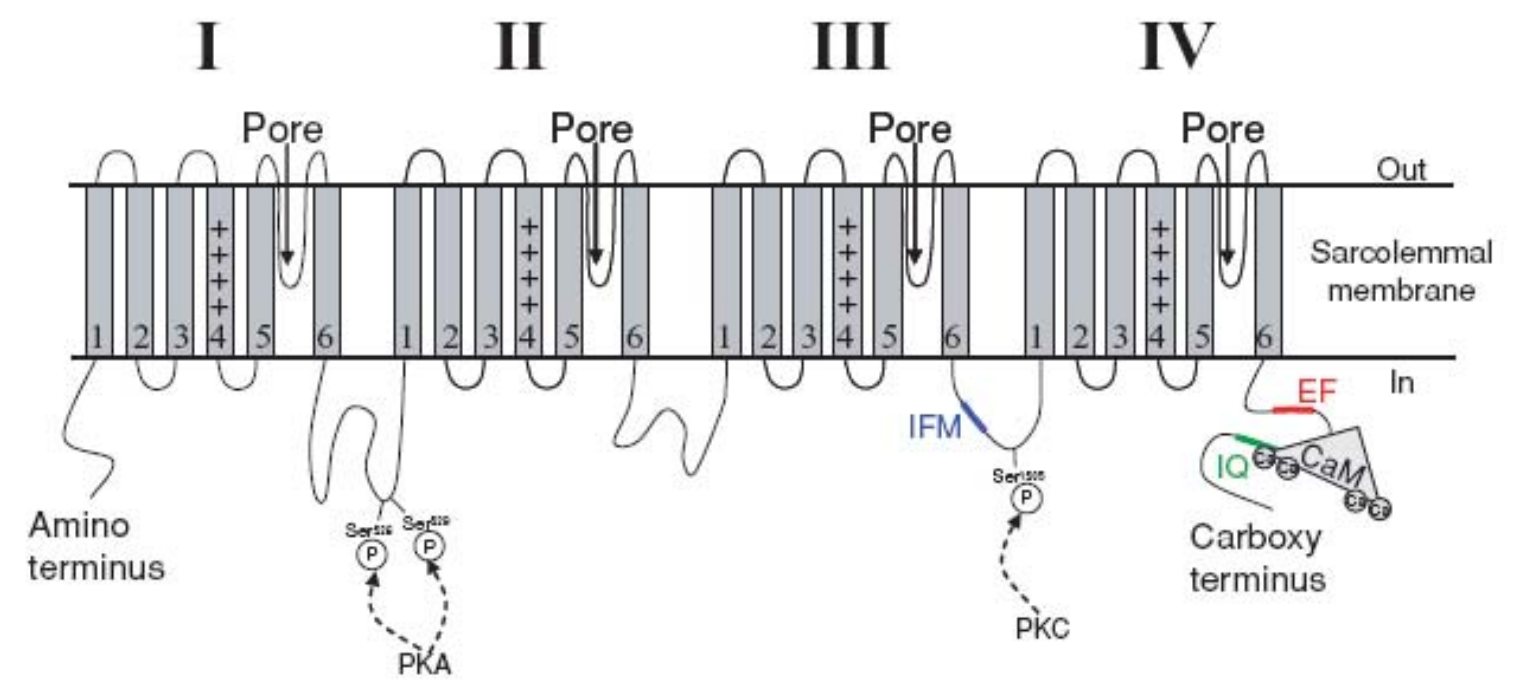

Figure 6. Structure of cardiac $\mathrm{Na}^{+}$channel Nav1.5 (SCN5A). The $\mathrm{Na}^{+}$channel has four domains (I-IV), each of which has six homologous repeating transmembrane regions (S1-S6) and a pore loop. Repetitive positively charged gating region in each $\mathrm{S} 4$ is indicated by ++++. Other noted sites are (1) PKA and PKC phosphorylation sites, (2) site possibly implicated in fast inactivation (inactivation gate; IFM), (3) IQ motif at the carboxy terminus, the putative site of $\mathrm{Ca}^{2+} / \mathrm{CaM}$ binding (from Wagner and Maier, 2006). 
positively charged, with a number of conserved arginines or lysines located at each third position. These S4 regions span to move within the electric field in response to changes in membrane potential $\left(E_{m}\right)$ : when the membrane becomes depolarized (outside negative), the voltage-sensing helices move toward the outer plasma membrane surface, causing an immediate conformational change in the gate segment that opens the channel for influx of $\mathrm{Na}^{+}$ions. In each domain there is also a pore loop between S5 and S6 which dips back into the membrane and lines the pore. The pore segments determine the $\mathrm{Na}^{+}$selectivity of the pore discriminating $\mathrm{Na}^{+}$from $\mathrm{Ca}^{2+}$ ions (Bers, 2001). The central pore (through which the ions move) is formed by the four domains with the S5 and S6 transmembrane segments as putative pore center, which confer selectivity and conductance. The $\mathrm{NH}_{2}$-and $\mathrm{COOH}$ terminals and the interdomain connector are intracellular. Phosphorylation sites were found between I and II as well as between III and IV cytoplasmic interdomain loops. The cytoplasmic connecting segments between domains I and II and between II and III are long, and that between domains III and IV is much shorter (Fozzard and Hanck, 1996).

At resting membrane potentials, cardiac $\mathrm{Na}^{+}$channels are in closed-available resting states. The sudden but short-lived depolarization of a region of the plasma membrane during an action potential is caused by a sudden massive, but transient, influx of $\mathrm{Na}^{+}$ions through the opened voltage-gated $\mathrm{Na}^{+}$channels in that region. The depolarization of the membrane changes the conformation of channel proteins, which then leads to the opening of the channels and allowing $\mathrm{Na}^{+}$influx through them. Once opened, the channels stay open for about $1 \mathrm{~ms}$, during which time about $6000 \mathrm{Na}^{+}$ions pass through. Further $\mathrm{Na}^{+}$influx is prevented by movement of the channel-inactivating segment into the channel opening. As long as the membrane remains depolarized, the channel is inactivated and cannot be reopened. This refractory period of $\mathrm{Na}^{+}$channel is important in determining the unidirectionality of the action potential. A few milliseconds after the resting potential is reestablished, the channels return to the closed resting state and are available for a subsequent depolarization. Compared to the resting state of the channel, inactivation is a process by which the $\mathrm{Na}^{+}$channel becomes unavailable for reopening until after membrane repolarization. Several types of $\mathrm{Na}^{+}$current inactivation can be distinguished: (a) fast inactivation occurring over tens of milliseconds that recovers rapidly at negative membrane potentials; (b) intermediate inactivation accumulates after fast inactivation and occurs over hundreds of milliseconds recovering more slowly; (c) slow inactivation occurs in the range of tens of seconds (Bers, 2001). It has been proposed that the cytoplasmic linker connecting domain III and IV of $\mathrm{Na}^{+}$channel acts as the inactivation gate (Stühmer 
et al., 1989). The most important residues for inactivation in this cytoplasmic linker are a triplet of the consecutive amino acids IFM: isoleucine-phenylalanine-methionine. The interaction of the linker between domain III and IV with the carboxy terminus is required for stabilization of the closed gate (Motoike et al., 2004).

\subsubsection{Regulation of $\mathrm{Na}^{+}$channel by protein kinases}

The regulation of $\mathrm{Na}^{+}$channels by protein kinases is isoform-specific. Murphy and colleagues (Murphy et al., 1996) showed that the cardiac $\mathrm{Na}^{+}$channel $\alpha$ subunit is phosphorylated by PKA at two sites in the I-II cytoplasmic linker (Ser-526 and Ser-529) in a cAMP-dependent manner. They also suggested that Ser-526 and Ser-529 play a role in the cAMP-dependent regulation of cardiac $\mathrm{Na}^{+}$channel activity. Upon phosphorylation by PKA, cardiac $\mathrm{Na}^{+}$channel gating remains unchanged, but whole-cell conductance increases (Frohnwieser et al., 1997). Single channel studies demonstrated that the resulting increase in whole-cell conductance was due to an increase in the number of functional $\mathrm{Na}^{+}$ channels but neither due to increased single channel current amplitude nor altered mean opening or closing time (Lu et al., 1999). However, $\beta$-adrenergic modulation of the cardiac $\mathrm{Na}^{+}$channel seems to be more complex. It has been reported that $\beta$-adrenergic receptor modulation of cardiac $\mathrm{Na}^{+}$current involves two different $\mathrm{G}$ protein-dependent mechanisms, one via PKA and the other via a direct modulation of $\mathrm{Na}^{+}$current by $\mathrm{G}$ protein stimulatory $\alpha$-subunit (Gs $\alpha$ ), which is independent of second messengers ( $\mathrm{Lu}$ et al., 1999). Other studies have revealed that the $\mathrm{Na}^{+}$current is decreased via stimulation of $\beta$ adrenergic receptors, and that the effect is secondary to the increased levels of intracellular cAMP, with acceleration of cAMP-dependent phosphorylation of the channel. This is in conflict with the hypothesis that PKA-dependent phosphorylation activates the $\mathrm{Na}^{+}$ current. It was also shown that a cAMP-dependent shift of $\mathrm{Na}^{+}$inactivation curve in the hyperpolarizing direction, which is consistent with the reduced function (Ono et al., 1989). $\mathrm{Ca}^{2+}$-dependent protein kinase (PKC) phosphorylates a serine residue in the III-IV linker (Ser-1505) of the cardiac $\mathrm{Na}^{+}$channel $\alpha$ subunit, and this phosphorylation reduces current through the cardiac $\mathrm{Na}^{+}$channels and is associated with a negative shift in the voltage dependence of channel inactivation, resulting in stronger inhibition of the current at more depolarized holding potentials (Qu et al., 1996). Furthermore, PKC-dependent phosphorylation of the cardiac $\mathrm{Na}^{+}$channel is partially responsible for the modulatory action of lysophosphatidylcholine that has been implicated in the arrhythmogenesis during ischemia (Watson and Gold, 1997). 


\subsection{3 $\mathrm{Na}^{+}$channel involvement in arrhythmias}

Mutations in the cardiac voltage-gated $\mathrm{Na}^{+}$channel underlie several arrhythmogenic disorders: the long-QT syndrome 3 (LQT3, linked to chromosome 3) (Bennett et al., 1995), the Brugada syndrome (Wang et al., 2000) and isolated cardiac conduction defects predisposing to life-threatening ventricular tachyarrhythmias (VT). These disorders cause distinct molecular effects, but all herald an exceptional risk for sudden death due to lifethreatening cardiac arrhythmias. Patients with the congenital long QT syndrome exhibit a delay in cardiac repolarization manifest as a prolonged QT interval in the electrocardiogram, increasing the risk of early and delayed afterdepolarizations. Mutations in long QT syndrome 3 alter amino acid residues in the inactivation gate and in the inactivation gate receptor region and thereby impair inactivation of $\mathrm{Na}^{+}$channels. The syndrome is associated with potentially lethal ventricular arrhythmias (Bennett et al., 1995).

Unlike the gain of function mutations leading to the long QT syndrome, loss of $\mathrm{Na}^{+}$ channel function has been causally linked to the Brugada syndrome. Brugada syndrome is an arrhythmogenic syndrome electrocardiographically characterized by coved ST-segment elevations and negative $\mathrm{T}$ waves that reflect electrical forces in the right ventricle but is not associated with QT-interval prolongation (Brugada and Brugada, 1992). The syndrome is associated with life-threatening ventricular tachyarrhythmias. Several mechanisms as consequences of the underlying mutations have been shown to reduce the current through $\mathrm{Na}^{+}$channels including the expression of nonfunctional channels, a reduced rate of recovery from inactivation, a faster open-state inactivation, an enhanced intermediate or slow inactivation, and protein trafficking defects (Viswanathan and Balser, 2004).

Isolated cardiac conduction disease is characterized in the electrocardiogram by a widening of the QRS complex consistent with the delayed ventricular excitation. The observed depolarizing shift of the $\mathrm{Na}^{+}$channel activation curve would reduce $\mathrm{Na}^{+}$channel current. The mutation results in bradycardia and causes syncope and sudden death. However, these mutations of the cardiac $\mathrm{Na}^{+}$channel are relatively rare. These arrhythmias are underlain more often by heart failure associated with an increased risk of sudden death mainly caused by VT and fibrillation and altered $\mathrm{Na}^{+}$channel function.

Beside the described mutations in cardiac $\mathrm{Na}^{+}$channel there are mutations in cardiac RyR2 which also can lead to arrhythmias. 


\subsection{Mutations in cardiac RyR2 gene as a cause for cardiac arrhythmias}

\subsubsection{RyR2 regulates cardiac contraction and rhythm}

$\mathrm{Ca}^{2+}$ release from the sarcoplasmic reticulum mediated by the cardiac ryanodine receptor is a fundamental event in cardiac muscle contraction. The RyR2 is primarily involved in cardiac contractile function and is a key element in the control of cardiac output. RyR2 are large homotetrameric complexes that are organized into functional $\mathrm{Ca}^{2+}$ release units via interaction with a multitude of accessory proteins, regulating the duration and amplitude of $\mathrm{Ca}^{2+}$ efflux from the SR (Marx et al., 2001). The large central protein RyR2 interacts with multiple accessory proteins to form a macromolecular complex. These regulatory proteins are located in the intracytoplasmic region (junction, triadin and calsequestrin) or in the cytosolic portion of RyR2 (calmodulin, PKA, CaMKII, PKC, protein phosphatase 1, protein phosphatase 2A, calcineurin) (Meissner, 2002). Defective regulation of RyR2 that leads to abnormal cellular $\mathrm{Ca}^{2+}$ handling has been implicated in heart failure, hypertrophy and arrhythmias (Marx et al., 2000; Wehrens et al., 2003; Jiang et al., 2002). RyR2 mutations suggested to cause defective $\mathrm{Ca}^{2+}$ channel function have recently been identified in a disease termed catecholaminergic polymorphic ventricular tachycardia (CPVT).

\subsubsection{Catecholaminergic polymorphic ventricular tachycardia}

The clinical presentation of CPVT is similar to that of LQT3 and is characterized by the occurrence of syncopal episodes in patients triggered by physical exercise or psychological stress. CPVT is an inherited arrhythmogenic disorder characterized by adrenergically mediated bidirectional or polymorphic ventricular tachycardia. It is a main cause of syncope and sudden cardiac death in individuals with a structurally normal heart. CPVT is a highly malignant cardiac disease manifesting in childhood and adolescence (Leenhardt et al., 1995; Priori et al., 2002). The autosomal dominant form of CPVT is caused by mutation in the RyR2 gene encoding the cardiac isoform of the ryanodine receptor (Priori et al., 2001). The nature of CPVT would suggest that these mutations alter the normal physiological response of the channel to an increased catecholaminergic drive during exercise. Bidirectional ventricular tachycardia is a rare and unusual arrhythmia being the most distinguishing characteristics of CPVT patients. To date, more than 70 RyR2 mutations have been reported in the "Gene Connection for the Heart" database for inherited arrhythmogenic diseases. The first family in which a RyR2 mutation was identified was affected by a highly malignant form of the disease that was resistant to beta 
blockers; the mutation present in the family (R4497C) is a hot spot that was subsequently identified in other CPVT patients unrelated to the first family members (Priori et al., 2002). Because this mutation was associated with a highly malignant phenotype it has been selected by several authors for their in vitro studies aimed at the functional characterization of RyR2 mutants. Cerrone and colleagues (Cerrone et al., 2005) have been the first developed a conditional knock-in mouse model carrier of the R4496C mutation $\left(\mathrm{RyR} 2^{\mathrm{R} 4496 \mathrm{C}+{ }^{-}}\right.$) that is the mouse equivalent of the human mutation $\mathrm{R} 4497 \mathrm{C}$ and demonstrated that the $\mathrm{RyR} 2^{\mathrm{R} 4496 \mathrm{C}+/-}$ mutation predisposes the murine heart to ventricular tachycardia and fibrillation in response caffeine and/or adrenergic stimulation, that closely mimics the clinical presentation of CPVT. Therefore, this knock-in mouse model is likely to become extremely useful to investigate RyR2-related arrhythmogenesis and the pathophysiology of CPVT.

Inherited genetic diseases have proven to be powerful models for studying complex syndromes. Hence it has been reasoned that inherited VT may provide an alternative approach to understanding VT in heart failure. 


\subsection{Aim of study}

Increased CaMKII activity has been linked to heart failure and ventricular arrhythmias. The latter can be caused by an altered $\mathrm{Na}^{+}$channel function. Therefore there might be a link between CaMKII and $\mathrm{Na}^{+}$channel function. Considering these, the aim of this study was to investigate:

1. whether $\mathrm{CaMKII} \delta_{\mathrm{C}}$ associates with $\mathrm{Na}^{+}$channels in isolated ventricular rabbit myocytes and mouse heart tissue;

2. whether this association results in $\mathrm{Na}^{+}$channel phosphorylation.

The R4496C mutation in cardiac RyR2 does not produce a phenotype under basal conditions (Cerrone et al., 2005). However, it remains unknown so far whether there are changes on the cellular level and whether it might become relevant under pathophysiological conditions. Therefore this study has aimed to investigate also:

1. intracellular $\mathrm{Ca}^{2+}$ handling in myocytes isolated from $\mathrm{RyR} 2^{\mathrm{R} 4496 \mathrm{C}+/-}$ knock-in mice;

2. possible alterations of E-C coupling and arrhythmogenic effects due to overexpression of CaMKII $\delta_{\mathrm{C}}$ in mouse hearts carrying the R4496C mutation in cardiac RyR2. 


\section{Materials}

\subsection{Animals}

Female Chinchilla bastard rabbits (with body weight of 1.5-2 kg) obtained from Charles River Laboratories (Sulzfeld) were used.

CaMKIII $\delta_{C}$ transgenic mice (Black Swiss), 3-month-old having a 3-fold increase in CaMKII activity and compared to their age- and sex-matched wild-type (WT) littermates were provided by Dr. Tong Zhang and Dr. Joan Heller Brown (USA). Knock-in mice (C57BL/6) harboring the R4496C mutation (RyR2 ${ }^{\mathrm{R} 4496 \mathrm{C}+/}$ ) were provided by Dr. Silvia G. Priori (Molecular Cardiology, Fondazione Salvatore Maugeri, Pavia, Italy). CaMKII $\delta_{C} /$ RyR2 $^{\mathrm{R} 4496 \mathrm{C}}$ mice were generated by crossbreeding $\mathrm{RyR} 2^{\mathrm{R} 4496 \mathrm{C}+/}$ mice with CaMKII $\delta_{\mathrm{C}}$ transgenic mice. CaMKII $\delta_{\mathrm{C}}, \mathrm{RyR}^{\mathrm{R} 4496 \mathrm{C}+/}, \mathrm{CaMKII} \delta_{\mathrm{C}} / \mathrm{RyR}^{\mathrm{R} 4496 \mathrm{C}}$ mice and respective WT controls, 8-14 weeks old, of either sex were used. All animals received humane care in accordance with the institution's guidelines, the German Convention for Protection of Animals and the National Institutes' of Health guidelines.

\subsection{Adenovirus constructs}

For the overexpression experiments the following adenoviral constructs were used:

- recombinant adenoviral vector encoding for hemagglutinin-tagged (HA-tagged) CaMKII $\left(\mathrm{Ad}-\mathrm{CaMKII} \delta_{\mathrm{C}}\right.$ ) that was kindly provided by T. Zhang (Kohlhaas et al., 2006; Zhu et al., 2003);

- recombinant adenovirus encoding for $\beta$-galactosidase (Ad-LacZ) which was generated in our laboratory and used before (Kohlhaas et al., 2006).

\subsection{Oligonucleotides for polymerase chain reaction}

Oligonucleotides of HPLC grade purity for polymerase chain reaction were obtained from MWG-Biotech (Munich):

\begin{tabular}{|l|l|l|}
\hline PCR-primer & Gene & $\begin{array}{l}\text { Size of amplified } \\
\text { DNA-fragment, bp }\end{array}$ \\
\hline $\begin{array}{l}\text { Forward: } \\
\text { 5'-TTGAAGGGTGCCATCTTGACA-3' }\end{array}$ & $\begin{array}{l}\text { Mouse- } \\
\text { CaMKII } \delta_{\mathrm{C}}\end{array}$ & 1000 \\
\hline
\end{tabular}




\begin{tabular}{|l|l|l|}
\hline $\begin{array}{l}\text { Reverse: } \\
\text { 5'-GGTCATGCATGCCTGGAATC-3' }\end{array}$ & & \\
\hline $\begin{array}{l}\text { Forward: } \\
\text { 5'-GCCTTCGCCATCAATTTCATCC-3' }\end{array}$ & Mouse-RyR2 & 800,1000 \\
\hline $\begin{array}{l}\text { Reverse: } \\
\text { 5'-CACTTTAGCAGTATCGCTGGAG-3' }\end{array}$ & & \\
\hline
\end{tabular}

\subsection{Antibodies}

\section{$\underline{\text { Anti-Calsequestrin Ab (PA1-913) }}$}

For the detection of calsequestrin using immunoblotting, affinity purified rabbit polyclonal antibody raised against purified canine cardiac calsequestrin was used (Affinity Bioreagents). Species reactivity: PA1-913 detects cardiac and skeletal muscle calsequestrin from canine, human, mouse, rabbit, rat, and sheep tissues.

\section{Anti-CaMKII Ab (M-176)}

For immunoprecipitation of CaMKII, rabbit polyclonal antibody raised against the recombinant protein corresponding to the amino acids 303-478 mapping at carboxy terminus of protein kinase II (CaMKII $\alpha$ ) of mouse origin was used (Santa Cruze Biotechnology, Inc.). Species reactivity: mouse, rat, human origin.

\section{$\underline{\text { Anti-GAPDH Ab (clone 6G5) }}$}

For detection of GAPDH using immunoblotting, mouse monoclonal antibody (clone 6G5) was used (Biotrend Chemikalien $\mathrm{GmbH}$ ). Species cross-reactivity: chicken, mouse, human, fish.

\section{$\underline{\text { Anti-HA Ab (clone 12CA5) }}$}

For the detection of HA-tagged CaMKIII $\delta_{\mathrm{C}}$ isoform using coimmunocytochemical staining, mouse monoclonal antibody (clone 12CA5) raised against peptide sequence derived from the human-influenza hemagglutinin protein was used (Roche Applied Science).

\section{$\underline{\text { Anti-Na }}+\underline{\mathrm{Ca}^{2+}}{ }^{2+}$-exchanger $\mathrm{Ab}(\mathrm{R} 3 \mathrm{~F} 1)$}


For detection of $\mathrm{Na}^{+} / \mathrm{Ca}^{2+}$-exchanger using immunoblotting, mouse monoclonal antibody raised against the canine $\mathrm{Na}^{+} / \mathrm{Ca}^{2+}$-exchanger was used (Swant, Switzerland). Species reactivity: monkey, horse, dog, rat, bovine and mouse tissue.

\section{$\underline{\text { Anti-Na }} \underline{1}$ 1.5 Ab (SKM2, SCN5A)}

For the detection of cardiac voltage-gated $\mathrm{Na}^{+}$channel using immunoblotting and coimmunocytochemical staining, rabbit polyclonal antibody raised against the peptide corresponding to the residues 493-511 of $\mathrm{rH1}$ was used after affinity purification via immobilized antigen column (Alomone Labs Ltd, Israel). Species reactivity: rat.

\section{$\underline{\text { Anti-Pan } \mathrm{Na}_{\underline{v}}} \underline{\mathrm{Ab}\left(\mathrm{SP} 19, \mathrm{Pan} \mathrm{Na}^{ \pm}\right.} \underline{\text { Channel) }}$}

For the detection of voltage-gated $\mathrm{Na}^{+}$channel using immunoblotting and immunoprecipitation, rabbit polyclonal antibody raised against the purified peptide corresponding to the residues $1500-1518$ of rat $\mathrm{Na}_{\mathrm{v}} 1.1$ and affinity purified on immobilized antigen was used (Alomone Labs Ltd, Israel). Species reactivity: rat, mouse.

\section{Anti-Phospholamban Ab (clone A1)}

For the detection of phosphorylated and non-phosphorylated forms of phospholamban using immunoblotting, mouse monoclonal antibody raised against bovine phospholamban purified from bovine cardiac sarcoplasmic reticulum was used (Upstate). Species crossreactivity: canine, bovine, rat, mouse and porcine.

\section{$\underline{\text { Anti-SERCA2 ATPase Ab (MA3-919) }}$}

For the detection of sarcoplasmic reticulum calcium 2 ATPase using immunoblotting, mouse monoclonal antibody raised against purified canine cardiac sarcoplasmic reticulum vesicles was used (Affinity Bioreagents). Species reactivity: human, mouse, rabbit, rat.

Secondary $\mathrm{Ab}$ (horse radish peroxidase conjugated):

donkey anti-rabbit whole IgG, Amersham/Freiburg; sheep anti-mouse whole IgG, Amersham/Freiburg.

Secondary Ab (dye conjugated):

goat anti-mouse Texas Red-conjugated affinity purified IgG, Jackson ImmunoResearch Laboratories, Inc.; 
goat anti-rabbit Fluorescein-conjugated affinity purified IgG, Jackson ImmunoResearch Laboratories, Inc.;

goat anti-rabbit Alexa Fluor 488 IgG, Molecular Probes, Inc.;

goat anti-mouse Alexa Fluor 555 IgG, Molecular Probes, Inc.

\subsection{Enzymes and nucleotides}

$\begin{array}{ll}\text { CaMKII } & \text { BioLabs/New England } \\ \text { dNTP } & \text { Invitrogen/USA } \\ \text { GoTaq }{ }^{\circledR} \text { DNA polymerase } & \text { Promega/Mannheim } \\ \text { Liberase Blendzyme 1 } & \text { Roche/Mannheim } \\ \text { Trypsin, 2,5\% liquid } & \text { Gibco/Invitrogen }\end{array}$

\subsection{Detection, purification and synthesis systems (kits)}

BCA Protein Assay, Pierce/Bonn

DNeasy® Blood \& Tissue Kit (50), Qiagen GmbH/Hilden

SuperSignal ${ }^{\circledR}$ West Pico Chemiluminescent Substrate, Pierce/Bonn

\subsection{Inhibitors}

Autocamtide 2-related inhibitory peptide (AIP), Sigma /Munich

KN-93, Seikagaku Corporation/Japan

Okadaic acid, Calbiochem/Merck

PKA/PKC inhibitor cocktail, Upstate/USA

Protein kinase A inhibitor, Sigma/Munich

Protease inhibitor cocktail tablets, EDTA-free, Roche/Mannheim 


\subsection{Stock solutions}

The stock solutions were prepared using $\mathrm{ddH}_{2} \mathrm{O}$, the $\mathrm{pH}$ values were adjusted at room temperature.

$\underline{\text { APS } 10 \%}$

For $10 \mathrm{ml} \quad$ Final concentration
APS
$1 \mathrm{~g}$
$10 \%$

The solution was dispensed into $100 \mu \mathrm{l}$ aliquots and stored at $-20^{\circ} \mathrm{C}$.

CHAPS stock

$\begin{array}{lll} & \text { For } 100 \mathrm{ml} & \text { Final concentration } \\ \text { CHAPS } & 10 \mathrm{~g} & 10 \% \\ \mathrm{ddH}_{2} \mathrm{O} & \text { to } 100 \mathrm{ml} & \end{array}$

The solution was stored at room temperature.

\section{DTT stock}

$\begin{array}{lll} & \text { For } 3 \mathrm{ml} & \text { Final concentration } \\ \text { DTT } & 46.3 \mathrm{mg} & 0.1 \mathrm{M} \\ \mathrm{ddH}_{2} \mathrm{O} & \text { to } 3 \mathrm{ml} & \end{array}$

The solution was dispensed into $100 \mu \mathrm{l}$ aliquots and stored at $-20^{\circ} \mathrm{C}$

EGTA $100 \mathrm{mM}$

$\begin{array}{lll} & \text { For } 100 \mathrm{ml} & \text { Final concentration } \\ \text { EGTA } & 3.804 \mathrm{~g} & 100 \mathrm{mM}\end{array}$

$\mathrm{pH}$ was adjusted with $\mathrm{KOH}$ to 8.0 . The solution was stored at $4^{\circ} \mathrm{C}$.

HEPES $100 \mathrm{mM}$

For $11 \quad$ Final concentration

$\begin{array}{lll}\text { HEPES } & 23.8 \mathrm{~g} & 100 \mathrm{mM}\end{array}$

$\mathrm{pH}$ was adjusted with $\mathrm{KOH}$ to 7 . The solution was stored at $4^{\circ} \mathrm{C}$. 
Magnesium chloride $1 \mathrm{M}$

$\begin{array}{lll} & \text { For } 100 \mathrm{ml} & \text { Final concentration } \\ \mathrm{MgCl}_{2} \times 6 \mathrm{H}_{2} \mathrm{O} & 20.33 \mathrm{~g} & 1 \mathrm{M}\end{array}$

The solution was stored at $4^{\circ} \mathrm{C}$.

$\underline{\text { PBS 10X }}$

For $11 \quad$ Final concentration

$\begin{array}{lll}\mathrm{NaCl} & 81.82 \mathrm{~g} & 1.4 \mathrm{M} \\ \mathrm{KCl} & 2 \mathrm{~g} & 27 \mathrm{mM} \\ \mathrm{Na}_{2} \mathrm{HPO}_{4} & 14.2 \mathrm{~g} & 100 \mathrm{mM} \\ \mathrm{KH}_{2} \mathrm{PO}_{4} & 2.45 \mathrm{~g} & 18 \mathrm{mM}\end{array}$

$\mathrm{pH}$ was adjusted with $\mathrm{HCl}$ to 7.3. The solution was sterile filtered and stored at room temperature.

$\underline{\text { Potassium aspartate } 2 \mathrm{M}}$

$\begin{array}{lll} & \text { For } 100 \mathrm{ml} & \text { Final concentration } \\ \mathrm{C}_{4} \mathrm{H}_{6} \mathrm{NO}_{4} \mathrm{~K} & 34.2 \mathrm{~g} & 2 \mathrm{M}\end{array}$

The solution was sterile filtered and stored at room temperature.

$\underline{\text { SDS } 10 \%}$

For $100 \mathrm{ml} \quad$ Final concentration

$\begin{array}{lll}\text { SDS } & 10 \mathrm{~g} & 10 \%\end{array}$

In the case of precipitation of SDS, the solution was warmed until clear.

$\underline{\text { Sodium chloride } 4 \mathrm{M}}$

For $11 \quad$ Final concentration

$\begin{array}{lll}\mathrm{NaCl} & 233.76 \mathrm{~g} & 4 \mathrm{M}\end{array}$

The solution was sterile filtered and stored at room temperature. 
$\underline{\text { Sodium fluoride } 200 \mathrm{mM}}$

$\begin{array}{lll} & \text { For } 100 \mathrm{ml} & \text { Final concentration } \\ \mathrm{NaF} & 0.84 \mathrm{~g} & 200 \mathrm{mM}\end{array}$

The solution was stored in the dark at $4^{\circ} \mathrm{C}$.

$\underline{\text { Sodium orthovanadate } 100 \mathrm{mM}}$

$\begin{array}{lll} & \text { For } 100 \mathrm{ml} & \text { Final concentration } \\ \mathrm{Na}_{3} \mathrm{VO}_{4} & 1.84 \mathrm{~g} & 100 \mathrm{mM}\end{array}$

Titration of the solution with $\mathrm{HCl}$ and sequential heating were repeated several times to adjust $\mathrm{pH}$ to 10.0 . The solution was stored in the dark at $4{ }^{\circ} \mathrm{C}$.

\section{$\underline{\text { Tris- } \mathrm{HCl} 2 \mathrm{M}}$}

For $11 \quad$ Final concentration

$\begin{array}{lll}\text { Tris- } \mathrm{HCl} & 315.2 \mathrm{~g} & 2 \mathrm{M}\end{array}$

$\mathrm{pH}$ value was adjusted to $\mathrm{pH}$ 7.4. The solutions were sterile filtered and stored at $4{ }^{\circ} \mathrm{C}$.

\subsection{Chemicals}

All chemicals used were at least p. a. quality.

Invitrogen/Karlsruhe

agarose

250 bp DNA ladder

Kodak/Paris, France

Developer

Merck/Darmstadt

All usual laboratory chemicals, glucose, ethanol, methanol, HPLC grade water, $\beta$-propanol, TEMED, disodium hydrogen phosphate-dihydrate $\left(\mathrm{Na}_{2} \mathrm{HPO}_{4} \cdot 2 \mathrm{H}_{2} \mathrm{O}\right)$, potassium dihydrogen phosphate $\left(\mathrm{KH}_{2} \mathrm{PO}_{4}\right)$, magnesium chloride 
Roth/Karlsruhe

Rotiphorese Gel 30 (30\% acrylamide stock solution with $0.8 \%$ bisacrylamide in proportion 37.5:1), glycine, D-glucose, milk powder

Sigma/Munich

All usual laboratory chemicals, adenosine triphosphate (disodium salt), ammonium hydrocarbonate, avertin, DTT, calcium chloride solution, creatine phosphokinase, ethidium bromide, L-glutathione reduced, glycerol, $\beta$-glycerophosphate, HEPES, medium M199, $\beta$ mercaptoethanol, paraformaldehyde, phosphocreatine, Ponceau S (ready to use solution), saponin, sodium fluoride, sodium orthovanadate, potassium chloride, potassium bicarbonate, sodium bicarbonate, sodium chloride, magnesium sulfate heptahydrate $\left(\mathrm{MgSO}_{4} \cdot 7 \mathrm{H}_{2} \mathrm{O}\right)$, phenol red sodium salt, taurine, 2,3-butanedione monoxime (BDM), caffeine, pluronic F-127, DMSO

Tetanal photowerk/Germany

Fixer solution

\subsection{Detergents}

\begin{tabular}{|l|l|}
\hline CHAPS & Roche/Mannheim \\
\hline SDS & BioRad/Munich \\
\hline Triton X-100 & Sigma/ Munich \\
\hline Tween 20 & BioRad Munich \\
\hline
\end{tabular}

\subsection{Proteins and protein standards}

\begin{tabular}{|l|l|}
\hline BCS (bovine calf serum) & HyClone/USA \\
\hline BSA-V (bovine serum Albumine fraction V) & Sigma/Munich \\
\hline Bromphenol blue, precision plus protein ${ }^{\mathrm{TM}}$ standards & BioRad/Munich \\
\hline Calmodulin $(\mathrm{CaM})$ & Upstate/USA \\
\hline Laminin & Sigma/Munich \\
\hline Protein G-sepharose FF & Amersham/Freiburg \\
\hline
\end{tabular}




\subsection{Fluorescent dyes}

Fluo-3 AM, Molecular Probes/USA

Fluo-4 AM, Molecular Probes/USA

Fura-2 AM, Sigma/Munich

\subsection{Other materials}

Chamber Slide, 4 well glass slide, Nunc/USA

Culture dishes (35 and $100 \mathrm{~mm})$, serological pipettes $(2,5,10,25 \mathrm{ml})$, transfer pipettes, Sarstedt/Germany

Nitrocellulose Transfer Membrane, $0.45 \mu \mathrm{m}$, PROTRAN ${ }^{\circledR}$, Whatman 3MM paper, Schleicher and Schuell/Dassel

Pipette tips, Brand/Wertheim

Sterile filter pipette tips, Biozym/Oldendorf

Sterile filter, $0.2 \mu \mathrm{m}$, Centricon ${ }^{\circledR}$ concentrators (MWCO 30000 and 100000 Da), Millipore/Eschborn

Safe-Lock tubes $(0.2,0.5,1.5$ and $2 \mathrm{ml})$, Eppendorf/Hamburg

X-ray films, Fuji/Düsseldorf

\subsection{Instruments}

Automatic pipettes, type Reference ${ }^{\circledR}$, Eppendorf/Hamburg Automatic pipettes, type PreCision, Biozym/Oldendorf Automatic pipettes, type Pipetman, Gilson/Bad Camberg 
Centrifuges:

\begin{tabular}{|l|l|}
\hline $\begin{array}{l}\text { Eppendorf bench-top centrifuge, type MiniSpin } \\
\text { 5415R }\end{array}$ & Eppendorf/Hamburg \\
Eppendorf centrifuge 5810R & \\
\hline Laborcentrifuge 3 K12 & Sigma/Munich \\
\hline Megafuge 2.0R & Heraeus Instruments/Hanau \\
\hline
\end{tabular}

Easy-Cast $^{\mathrm{TM}}$ Electrophoresis system for DNA electrophoresis, model \#B1, peqlab/Erlangen

Electrophoresis apparatus, type Mini-Protean ${ }^{\circledR} 3$, BioRad/Munich

Electroblotting apparatus, type Mini Trans-Blot ${ }^{\circledR}$, BioRad/Munich

End-over-end rotator, Heto Lab Equipment/Denmark

Eppendorf BioPhotometer, Eppendorf/Hamburg

Gas controlled incubators "Function Line", Heraeus/Hanau

Homogenizer Miccra D-1, DS-5/K1 ART-Labortechnik/Germany

Ice machine, Ziegra/Isernhagen

Laser scanning confocal microscope LSM 5 Pascal, Zeiss/Germany

Magnetic mixer with warming, type M21/1 Framo-Gerätetechnik/Germany

Microscope, Nikon Eclipse TE300/Japan

Microwave oven, Siemens/Germany

MultiImage Light Cabinet with built-in ultraviolet emitter and video camera, Alpha Innotech Corporation. The instrument is used for documentation of X-ray films and gels 
Optical setup, IonWizard/Netherlands

pH-Meter Basic Meter PB-20 Sartorius/Göttingen

Plate reader KC4, BIO-TEK ${ }^{\circledR}$ Instruments, inc./USA

PowerPac ${ }^{\mathrm{TM}}$ universal power supply, BioRad/Munich

Shaker Duomax 1030 Heidolph/Germany

Sterile bench, class II, Clean Air/Hilden

Thermocycler, type Mastercycler ${ }^{\circledR}$ gradient, Eppendorf/Hamburg

Thermomixer 5436, Eppendorf/Hamburg

UV/Visible spectrophotometer, Ultrospec 3000, Amersham Biosciences/Freiburg

Ultraviolet emitter, $312 \mathrm{~nm}$, Bachofer/Reutlingen

Vortex, Genie 2 ${ }^{\mathrm{TM}}$, Bender and Hobein AG/Zurich

Water bath 1083, GFL/Burgwedel

X-ray film cassettes $10 \times 18$, Siemens/Germany 


\section{Methods}

\subsection{Polymerase chain reaction (PCR)}

The mice used in the experiments originate from two mouse lines with different genetic backgrounds (Black Swiss and C57BL/6). The former mouse line overexpressed cytoplasmic CaMKIIIc in the heart, the latter mouse line was the carrier of the R4496C mutation in the heart. The DNA from the pieces of mouse ears was isolated and the genotype was verified using polymerase chain reaction (PCR). PCR allows amplification of DNA fragments due to repetitive cycles of DNA synthesis.

The DNA from the mouse ear punch was purified using DNeasy Tissue Kit from Qiagen. For this, the ear punch tissue from each mouse was placed into $1.5 \mathrm{ml}$ tube containing 180 $\mu 1$ of ATL buffer supplemented with $20 \mu \mathrm{l}$ of proteinase K. The samples were incubated in the thermomixer at $55^{\circ} \mathrm{C}$ with shaking for $15 \mathrm{sec}$ after every $1 \mathrm{~min}$ of the rest until the tissue was completely lysed. The samples were subsequently vortexed for $15 \mathrm{sec}$ and $400 \mu \mathrm{l}$ of buffer AL-ethanol mixture was added and mixed vigorously by vortexing to yield a homogeneous solution. The mixture was pipetted into the DNeasy spin column placed in a new $2 \mathrm{ml}$ collection tube and centrifuged at $6000 \mathrm{x}$ g for $1 \mathrm{~min}$. The DNeasy spin column was placed in a new $2 \mathrm{ml}$ collection tube and loaded with $500 \mu \mathrm{l}$ of AW1 buffer. The column was centrifuged for $1 \mathrm{~min}$ at $6000 \mathrm{x}$ g. The DNeasy spin column was again placed in a new $2 \mathrm{ml}$ collection tube, washed with $500 \mu \mathrm{l}$ of AW1 buffer and centrifuged for $3 \mathrm{~min}$ at full speed to dry the DNeasy membrane. Flow-through and collection tube were discarded after every centrifugation step. The DNeasy spin column was placed in a clean $1.5 \mathrm{ml}$ tube, $100 \mu \mathrm{l}$ of AE buffer were pipetted directly onto the DNeasy membrane and incubated at room temperature for $1 \mathrm{~min}$. After this the sample was eluted from the membrane by centrifugation for $1 \mathrm{~min}$ at $6000 \mathrm{x}$ g. The DNA concentration in the samples was measured using Eppendorf BioPhotometer.

The PCR reaction was performed with CaMKII $\delta_{C^{-}}$and RyR2-specific primers. The PCR lasted for 35 cycles in the case of CaMKII $\delta_{C}$ and 34 cycles in the case of RyR2 under the following conditions:

1. 5 min denaturation at $94^{\circ} \mathrm{C}$

2. 1 min annealing at $60^{\circ} \mathrm{C}$ or 30 seconds at $55^{\circ} \mathrm{C}$ for CaMKII $\delta_{\mathrm{C}}$ or RyR2, respectively

3. 2 min or 90 seconds DNA synthesis at $72^{\circ} \mathrm{C}$ for CaMKII $\delta_{\mathrm{C}}$ or RyR2, respectively 
The denaturation step at $95^{\circ} \mathrm{C}$ before the first cycle was extended for 5 minutes. After the last cycle, the synthesis step was prolonged for 7 minutes to finish synthesis of incompletely synthesized DNA strands.

The PCR was performed with the GoTaq ${ }^{\circledR}$ DNA polymerase (Promega). The specific buffers and solutions were received with the polymerase. dNTP master mix from Invitrogen was used.

\section{PCR reaction mixture:}

$5 \mu 1$ 10X PCR buffer (500 mM Tris- $\left.\mathrm{HCl} \mathrm{pH} \mathrm{9.1,} 140 \mathrm{mM}\left(\mathrm{NH}_{4}\right)_{2} \mathrm{SO}_{4}\right)$

$3 \mu \mathrm{MgCl} \mathrm{Mg}_{2}(25 \mathrm{mM})$

$1 \mu 1100 \mathrm{mM}$ dNTP mix (25 mM of each dATP, dCTP, dGTP, dTTP)

$2 \mu 1$ template (cDNA) obtained as described above

$1 \mu l$ forward primer

$1 \mu 1$ reverse primer

$0.4 \mu 1$ Taq polymerase

$36.6 \mu$ volume was adjusted with sterile DEPC $\mathrm{ddH}_{2} \mathrm{O}$

To check the size of the PCR product, a $7 \mu 1$ aliquot of the PCR reaction was electrophoretically analyzed in a $1 \%$ agarose gel.

\subsubsection{Electrophoresis conditions}

For preparation of a 1\% gel, $0.8 \mathrm{~g}$ of agarose was dissolved by heating in $40 \mathrm{ml}$ of $1 \mathrm{X}$ TBE buffer. For visualization of the bands, $1.6 \mu 1$ of ethidium bromide (Invitrogen) was added to the mixture. After mixing, the gel was poured into the prepared gel tray. In the mean time of the polymerization, the samples were prepared for loading by mixing of $7 \mu 1$ of DNA probe with $3.5 \mu$ of $5 \mathrm{X}$ loading buffer.

After polymerization, the gel was placed into an electrophoresis chamber filled with $1 \mathrm{X}$ TBE buffer, the samples were loaded, and the electrophoresis was performed at $100 \mathrm{~V}$ for $60 \mathrm{~min}$.

\subsubsection{Visualization of DNA in the gel}

Ethidium bromide is a fluorescent dye which contains a planar group that intercalates between the stacked bases of the DNA. The fixed position of this group and its close proximity to the bases cause dye, bound to DNA, to display an increased fluorescence 
yield compared to that of the dye in free solution. Ultraviolet radiation at $254 \mathrm{~nm}$ is absorbed by the DNA and transmitted to the dye; radiation at $302 \mathrm{~nm}$ and $366 \mathrm{~nm}$ is absorbed by the bound dye itself. In both cases, the energy is reemitted at $590 \mathrm{~nm}$ in the red orange region of the visible spectrum. Hence, DNA can be visualized under a UV transilluminator. The gel was photographed using a video camera built in the MultiImage Light Cabinet.

$\underline{10 X \mathrm{TBE}}$

For $11 \quad$ Final concentration

Tris base $\quad 54 \mathrm{~g} \quad 450 \mathrm{mM}$

Borate $27.5 \mathrm{~g} \quad 450 \mathrm{mM}$

EDTA $4.15 \mathrm{~g} \quad 10 \mathrm{mM}$

$\underline{1 \mathrm{X} T B E}$

For 11

10X TBE $100 \mathrm{ml}$

$\mathrm{ddH}_{2} \mathrm{O}$ to 11

$\underline{5 X \text { loading buffer }}$

$\begin{array}{lll} & \text { For } 10 \mathrm{ml} & \text { Final concentration } \\ \text { Bromphenol Blue } & 20 \mathrm{mg} & 0.2 \% \\ \text { Glycerol } & 5 \mathrm{ml} & 50 \% \\ 5 \mathrm{X} \text { TBE } & 1 \mathrm{ml} & 0.5 \mathrm{X}\end{array}$

The buffer was stored at $4^{\circ} \mathrm{C}$.

\subsection{Adenoviral transfection and culture of adult rabbit ventricular cardiomyocytes}

Ventricular cardiomyocytes were isolated from rabbit hearts using the well established standard protocol (Animal experiment announcement $\mathrm{T}$ 9.02, "Killing of animals for scientific purposes" submitted by Dr. med. Harald Kögler) that was kindly provided by the group of Prof. Dr. med. Hasenfuß (Schillinger et al., 2000; Wagner et al., 2003). 


\subsubsection{Preparation of laminin culture dishes}

Prior to plating the cells, culture dishes $(100 \mathrm{~mm})$ were covered with M 199/laminin mixture $(3 \mathrm{ml} / 30 \mu \mathrm{l})$ to provide better attachment of the cells to the bottom and incubated at $37^{\circ} \mathrm{C}$ for $1 \mathrm{~h}$ before use.

For transfection of cardiomyocytes, adenovirus-mediated gene transfer was used. The replication of DNA-containing adenoviruses occurs epichromosomally, which makes them a system of choice to study gene expression in primary non-replicative cells, which the cardiomyocytes are. The recombinant adenoviruses coding for HA-tagged $\mathrm{CaMKII} \delta_{\mathrm{C}}$ and $\beta$-galactosidase as control were amplified in our laboratory.

The cells were transfected immediately after preparation directly in the suspension $\left(5 \times 10^{5}\right.$ cells per dish in the $5 \mathrm{ml}$ of M199) and plated on laminin-coated culture dishes. After the attachment phase of 3 hours, the medium was replaced with fresh M199 (10 ml per dish) and the cells were cultured for 24 hours. The incubation of the cardiomyocytes was performed in a gas-controlled incubator in water vapor saturated air containing $5 \% \mathrm{CO}_{2}$ at $37^{\circ} \mathrm{C}$.

\subsubsection{Calculation of virus quantity taken for transfection}

The amount of virus taken for experiments is expressed as a multiplicity of infection (MOI), which is the number of active viral particles per cell. MOI of used viruses was calculated based on the virus concentration estimated in plaque test assays and measured in plaque forming units per $\mathrm{ml}(\mathrm{pfu} / \mathrm{ml})$. The amount of virus corresponding to MOI 100 was used in experiments of transgene overexpression.

For the calculation of the amount of virus corresponding to the desired MOI, the following formula was used:

$$
V_{\text {stock }}=\frac{M O I \times a_{c t}}{C_{\text {stock }}}, \text { where }
$$

$a_{c t}$ - total amount of cells to be infected with the virus

$V_{\text {stock }}$ - volume of virus stock to be added

$C_{\text {stock }}$ - concentration of virus in $\mathrm{pfu} / \mu 1$ 


\subsection{Total protein homogenate preparation}

\subsubsection{Protein lysate preparation from rabbit ventricular cardiomyocytes}

All steps were performed at $4^{\circ} \mathrm{C}$ to prevent proteolytic degradation of the proteins. The cells, harvested and pelleted as described above (see section 3.2), were homogenized in $300 \mu \mathrm{l}$ of lysis buffer. For better solubilization of the proteins, the samples were kept on ice for 20 minutes with occasional vortexing. Obtained primary lysates were passed through a $21 \mathrm{G}$ needle 5 times. To pellet the nuclei and cell debris, crude homogenates were centrifuged for 8 minutes at $3000 \mathrm{x} \mathrm{g}\left(4^{\circ} \mathrm{C}\right)$. The protein concentration of supernatants was determined by the BCA method using the kit from Pierce (Pierce Chemical Co). The samples were used as a starting material for immunoprecipitation and co-immunoprecipitation experiments. For Western blot measurements, aliquots of the prepared lysates corresponding to $25 \mu \mathrm{g}$ of total protein were denatured in sample buffer containing $2 \% \beta$-mercaptoethanol by warming at $37^{\circ} \mathrm{C}$ for 30 minutes and subjected to SDS-polyacrylamide gel electrophoresis (SDS-PAGE).

Lysis buffer

$\begin{array}{lll} & \text { For } 10 \mathrm{ml} & \text { Final concentration } \\ 2 \mathrm{M} \mathrm{Tris}-\mathrm{HCl}, \mathrm{pH} 7.4 & 100 \mu \mathrm{l} & 20 \mathrm{mM} \\ 4 \mathrm{M} \mathrm{NaCl} & 500 \mu \mathrm{l} & 200 \mathrm{mM} \\ 200 \mathrm{mM} \mathrm{NaF}^{2} & 1 \mathrm{ml} & 20 \mathrm{mM} \\ 100 \mathrm{mM} \mathrm{Na}_{3} V_{4} & 100 \mu \mathrm{l} & 1 \mathrm{mM} \\ 100 \mathrm{mM} \mathrm{DTT}^{\mathrm{m}} & 100 \mu \mathrm{l} & 1 \mathrm{mM} \\ 10 \% \mathrm{CHAPS} & 200 \mu \mathrm{l} & 2 \% \\ \mathrm{ddH}_{2} \mathrm{O} & \text { to } 10 \mathrm{ml} & \end{array}$

Prior to use the complete protease inhibitor cocktail (Roche) was added.

$\underline{5 X \text { sample buffer }}$

For $20 \mathrm{ml}$

Tris- $\mathrm{HCl}$

SDS

Glycerol
$0.79 \mathrm{~g}$

$2 \mathrm{~g}$

$10 \mathrm{ml}$
Final concentration $250 \mathrm{mM}$

$10 \%$

$50 \%$ 
The components were dissolved in $\mathrm{ddH}_{2} \mathrm{O}$ (up to $18 \mathrm{ml}$ ), $\mathrm{pH}$ was adjusted with $\mathrm{HCl}$ to 6.8 and finally the following components were added:

$\begin{array}{lll} & \text { For } 20 \mathrm{ml} & \text { Final concentration } \\ \text { Bromphenol Blue } & 5 \mathrm{mg} & 250 \mu \mathrm{g} / \mathrm{ml} \\ \beta \text {-mercaptoethanol } & 2 \mathrm{ml} & 10 \%\end{array}$

The solution was aliquoted and stored at $-20^{\circ} \mathrm{C}$. Protein samples were mixed with the sample buffer in the proportion of $4: 1$, respectively.

\subsubsection{Protein homogenate preparation from mouse heart tissue}

All steps of the procedure were performed at $4{ }^{\circ} \mathrm{C}$ to prevent proteolytic degradation of the proteins. The whole mouse heart was immersed in homogenization buffer, trimmed of fat and connective tissue and minced with scissors to pieces as small as possible. Minced tissue was homogenized in 1 volume of homogenization buffer using homogenizer Miccra D-1, DS-5/K1 ART-(Labortechnik) at maximum speed 4 times for 5 seconds each time. The homogenate was centrifuged for 10 minutes at $3000 \mathrm{x} g$ to pellet the nuclei and particular matter. The supernatant from this centrifugation was removed in a fresh safelock tube and the pellet was re-homogenized by hand homogenization ( 8 strokes) in 1.5 safe-lock tube with a tightly fitted teflon pestle in initial volume of homogenization buffer. Afterwards, the suspension was kept on ice for better solubilization of the proteins for 30 minutes with following centrifugation as describe above. The supernatants from 2 centrifugation steps were pooled and the protein concentration was determined by the BCA method using the kit from Pierce. This supernatant was used as a starting material for immunoprecipitation and co-immunoprecipitation experiments. For Western blot aliquots of the prepared homogenate were denatured in sample buffer containing $2 \% \beta$ mercaptoethanol by warming at $37^{\circ} \mathrm{C}$ for 30 minutes and $50 \mu \mathrm{g}$ of total protein was subjected to SDS-polyacrylamide gel electrophoresis (SDS-PAGE).

Homogenization buffer

$\begin{array}{lll} & \text { For } 10 \mathrm{ml} & \text { Final concentration } \\ 2 \mathrm{M} \mathrm{Tris-HCl}, \mathrm{pH} 7.4 & 100 \mu \mathrm{l} & 20 \mathrm{mM} \\ 4 \mathrm{M} \mathrm{NaCl} & 500 \mu \mathrm{l} & 200 \mathrm{mM} \\ 200 \mathrm{mM} \mathrm{NaF} & 1 \mathrm{ml} & 20 \mathrm{mM} \\ 100 \mathrm{mM} \mathrm{Na}_{3} \mathrm{VO}_{4} & 100 \mu \mathrm{l} & 1 \mathrm{mM}\end{array}$




$\begin{array}{lll}100 \mathrm{mM} \mathrm{DTT} & 100 \mu \mathrm{l} & 1 \mathrm{mM} \\ \text { Triton X-100 } & 100 \mu \mathrm{l} & 1 \% \\ \mathrm{ddH}_{2} \mathrm{O} & \text { to } 10 \mathrm{ml} & \end{array}$

Prior to use the complete protease inhibitor cocktail (Roche) was added.

\subsection{Co-immunoprecipitation}

\subsubsection{Formation of the antigen-antibody complex}

Cardiac homogenates ( $1 \mathrm{mg}$ of protein in each sample), prepared from TG CaMKII $\delta_{\mathrm{C}}$ and WT mouse hearts as described in 3.3.2, or lysates ( $0.5 \mathrm{mg}$ of protein in each sample), prepared from rabbit ventricular myocytes transfected with $\mathrm{CaMKII}_{\mathrm{C}}$ and $\mathrm{LacZ}$ using a MOI of 100 as described in 3.3.1, were suspended in dilution medium to bring the volume of each sample up to $500 \mu 1$. The samples were kept on ice for 30 minutes with occasional vortexing. $3 \mu \mathrm{g}$ of rabbit polyclonal anti-CaMKII antibody (M-176, Santa Cruz Biotechnology Inc.) were added to the samples. Samples were incubated using an endover-end rotator set at low speed at $4{ }^{\circ} \mathrm{C}$ overnight. Rabbit polyclonal anti-Cav1.2a antibody (Alomone Labs) added to one sample at a quantity of $3 \mu \mathrm{g}$ served as a control antibody. One sample was incubated with protein G-sepharose beads only.

\subsubsection{Precipitation of immune complexes}

Protein G-sepharose Fast Flow (Amersham Biosciences) was prepared as follows: per each $\mathrm{ml}$ of bed volume, $1.33 \mathrm{ml}$ of $75 \%$ slurry in $20 \%$ ethanol is needed; based on this ratio, a sufficient amount of $75 \%$ slurry was transferred to a $15 \mathrm{ml}$ tube and the matrix was sedimented by centrifugation at $500 \mathrm{x} \mathrm{g}_{\max }$ for 5 minutes. The supernatant was carefully aspirated with a pipette. Next, protein G-sepharose was washed with 10 bed volumes of dilution medium and sedimented as described above. The supernatant was discarded and for each $1.33 \mathrm{ml}$ of the original slurry of protein G-sepharose $1 \mathrm{ml}$ of dilution media was added. This procedure produced $50 \%$ slurry. $100 \mu \mathrm{l}$ of this slurry was added to each sample with preformed antigen-antibody complexes. The mixture was gently mixed for 2 hours at $4^{\circ} \mathrm{C}$ using an end-over-end rotator set at low speed. After the end of the incubation time, the matrix was sedimented by centrifugation for 30 seconds at $14000 \mathrm{x} g$ in Eppendorf 
bench-top MiniSpin centrifuge. The supernatants were discarded with a $29 \mathrm{G}$ cannula connected to a syringe and the pellets were washed 3 times with $500 \mu l$ (for cardiac homogenates) and $250 \mu \mathrm{l}$ (for cell lysates) of RIPA buffer. The tubes were inverted carefully 5 times to mix. After each washing step, the immunoprecipitates were recovered by centrifugation as described above.

\subsubsection{Analysis}

The immunoprecipitated proteins were eluted in $60 \mu 1$ (for cardiac homogenates) and in 40 $\mu \mathrm{l}$ (for cell lysates) of $2 \mathrm{X}$ sampler buffer, warmed at $37^{\circ} \mathrm{C}$ for 30 minutes and centrifuged for 2 minutes at $14000 \mathrm{x}$ g. The supernatants were carefully transferred into a fresh safelock tube and analyzed by immunoblotting.

Dilution medium (prepared just prior to use)

Final concentration

$\begin{array}{lll}\text { Modified RIPA buffer } & 5 \mathrm{ml} & \\ 200 \mathrm{mM} \mathrm{NaF} & 25 \mu \mathrm{l} & 1 \mathrm{mM} \\ 100 \mathrm{mM} \mathrm{Na}_{3} \mathrm{VO}_{4} & 50 \mu \mathrm{l} & 1 \mathrm{mM} \\ 100 \mathrm{mM} \mathrm{DTT}^{\mathrm{m}} & 50 \mu \mathrm{l} & 1 \mathrm{mM}\end{array}$

The complete protease inhibitor cocktail (Roche) were added

$\underline{\text { Modified RIPA buffer }}$

$\begin{array}{lll} & \text { For } 50 \mathrm{ml} & \text { Final concentration } \\ 2 \mathrm{M} \text { Tris-HCl, pH } 7.4 & 1.25 \mathrm{ml} & 50 \mathrm{mM} \\ 4 \mathrm{M} \mathrm{NaCl} & 1.93 \mathrm{ml} & 154 \mathrm{mM} \\ \text { Triton X-100 } & 125 \mu \mathrm{l} & 0.25 \% \\ \mathrm{ddH}_{2} \mathrm{O} & \text { to } 50 \mathrm{ml} & \\ & & \\ 2 \mathrm{X} \text { sample buffer } & & \\ & \text { For } 20 \mathrm{ml} & 100 \mathrm{mM} \\ \text { Tris-HCl } & 0.32 \mathrm{~g} & 4 \% \\ \text { SDS } & 0.8 \mathrm{~g} & 20 \% \\ \text { Glycerol } & 4 \mathrm{ml} & \end{array}$


The components were dissolved in $\mathrm{ddH}_{2} \mathrm{O}$ (up to $19.2 \mathrm{ml}$ ), $\mathrm{pH}$ was adjusted with $\mathrm{HCl}$ to 6.8 and finally the following components were added:

$\begin{array}{lll} & \text { For } 20 \mathrm{ml} & \text { Final concentration } \\ \text { Bromphenol Blue } & 2 \mathrm{mg} & 100 \mu \mathrm{g} / \mathrm{ml} \\ \beta \text {-Mercaptoethanol } & 0.8 \mathrm{ml} & 4 \%\end{array}$

Solution was aliquoted and stored at $-20^{\circ} \mathrm{C}$.

\subsection{Immunoblotting}

Samples for loading, obtained as described in the previous chapters, were mixed with sample buffer and warmed for 30 minutes at $37^{\circ} \mathrm{C}$.

\subsubsection{Casting of SDS-polyacrylamide gel}

For hand casting of the gels for vertical electrophoresis, a Mini-PROTEAN ${ }^{\mathrm{TM}}$ III Electrophoresis Cell (BioRad) was used. Solutions for the separating gels of the desired percentage and for the 5\% stacking gel were prepared as described below. The casting of the gels was performed according to manufacturer's instructions.

The separation gel $(7.5 \mathrm{ml}$ for $1.5 \mathrm{~mm}$ gel thickness) was poured between the inner $(7.3 \times 10.2 \mathrm{~cm})$ and outer $(8.3 \times 10.2 \mathrm{~cm})$ glass plates. The gel was carefully overlaid with $2-$ propanol to create a barrier to oxygen, which inhibits the polymerization. After the gel has set (about $20 \mathrm{~min}$ at RT), the overlay was poured off and the top of the separating gel was washed with distilled water. The solution of stacking gel was poured directly onto the polymerized separating gel. The slots were formed by placing an appropriate comb into the gel solution. The polymerization took approximately $10 \mathrm{~min}$.

\subsubsection{SDS-polyacrylamide gel electrophoresis (SDS-PAGE) and electrophoretic transfer}

The samples were loaded onto the bottom of the wells. Electrophoresis was run at a constant current of $30 \mathrm{~mA}$ per gel. The Dual Color protein marker (Bio-Rad) was used as molecular weight standards. Western blotting was carried out by electrophoretic transfer essentially as described by Towbin (Towbin et al., 1979). Prior to stopping the gel running, 
fiber pads, filter paper and nitrocellulose transfer membrane $(0.45 \mu \mathrm{m}$ pore size $)$ were soaked in transfer buffer. After electrophoresis, the gel was plated apart and immersed in transfer buffer. For electrophoretic transfer of proteins from the gel to a membrane, a MiniTrans-Blot ${ }^{\circledR}$ Cell (BioRad), compatible with the described system for electrophoresis, was utilized. The transblot sandwich was assembled according to the manufacturer's instructions in the following order starting from the anode side: sponge, 2 sheets of filter paper, nitrocellulose membrane, gel, 2 sheets of filter paper, sponge. The assembled transblot sandwich was inserted into the transblot cell filled with the transfer buffer. An ice-cooling unit was set behind the cathode side of transblot cell. The transfer was performed for 2 hours at $400 \mathrm{~mA}$ with one change of the ice-cooling unit after the first hour.

\subsubsection{Staining the membrane with Ponceau $S$}

Ponceau S can be used routinely to verify quality of protein transfer from SDS-PAAG to nitrocellulose membrane. It is applied in acidic aqueous solution. Staining is rapid but not permanent; the red stain is washed away in subsequent processing. Since the binding is reversible, the stain is compatible with most antigen visualization techniques.

The membrane was immersed in freshly diluted Ponceau S solution and incubated for 1 min at room temperature with gentle agitation on the rocking platform. Afterwards, the membrane was distained for 1-2 min with several changes of $1 \mathrm{X}$ washing buffer.

\subsubsection{Immunovisualization}

After transfer, the membrane was incubated on a rocking platform with blocking solution overnight at $4^{\circ} \mathrm{C}$ (or alternatively, for 60 minutes at room temperature). Next, the membrane was incubated with primary antibody diluted in the antibody dilution buffer for 2 hours at room temperature. After washing (six times five minutes each), the membrane was incubated with HRP-conjugated secondary antibody diluted in the antibody dilution buffer for 1 hour at room temperature. Afterwards the membrane was washed as before. For the chemiluminescent detection, SuperSignal ${ }^{\circledR}$ West Pico Chemiluminescent Substrate (Pierce) was used. Substrate working solution was prepared by mixing of equal volumes of two substrate components. The membrane was incubated with substrate working solution for 5 minutes at room temperature, laid between sheets of transparent plastic protector and 
exposed to X-ray film, which was developed afterwards according to manufacturer's instructions.

Separating gel

\begin{tabular}{|l|l|l|l|l|l|l|}
\hline \multirow{2}{*}{ Components } & \multicolumn{2}{|l|}{$7.5 \%$ gel } & \multicolumn{2}{l|}{$10 \%$ gel } & \multicolumn{2}{l|}{$15 \%$ gel } \\
\cline { 2 - 7 } & $10 \mathrm{ml}$ & $20 \mathrm{ml}$ & $10 \mathrm{ml}$ & $20 \mathrm{ml}$ & $10 \mathrm{ml}$ & $20 \mathrm{ml}$ \\
\hline $\begin{array}{l}\text { Rotiphorese } \\
\text { Gel } 30\end{array}$ & $2.5 \mathrm{ml}$ & $5 \mathrm{ml}$ & $3.33 \mathrm{ml}$ & $6.66 \mathrm{ml}$ & $4.45 \mathrm{ml}$ & $8.9 \mathrm{ml}$ \\
\hline $\begin{array}{l}4 \mathrm{X} \text { Tris/SDS, } \\
\mathrm{pH} 8.8\end{array}$ & $2.5 \mathrm{ml}$ & $5 \mathrm{ml}$ & $2.5 \mathrm{ml}$ & $5 \mathrm{ml}$ & $2.5 \mathrm{ml}$ & $5 \mathrm{ml}$ \\
\hline $\mathrm{ddH} \mathrm{H}_{2} \mathrm{O}$ & $4.9 \mathrm{ml}$ & $9.8 \mathrm{ml}$ & $4.1 \mathrm{ml}$ & $8.2 \mathrm{ml}$ & $2.45 \mathrm{ml}$ & $4.9 \mathrm{ml}$ \\
\hline $10 \%$ APS & $100 \mu \mathrm{l}$ & $200 \mu \mathrm{l}$ & $100 \mu \mathrm{l}$ & $200 \mu \mathrm{l}$ & $100 \mu \mathrm{l}$ & $200 \mu \mathrm{l}$ \\
\hline TEMED & $10 \mu \mathrm{l}$ & $20 \mu \mathrm{l}$ & $10 \mu \mathrm{l}$ & $20 \mu \mathrm{l}$ & $10 \mu \mathrm{l}$ & $20 \mu \mathrm{l}$ \\
\hline
\end{tabular}

5\% stacking gel

$\begin{array}{ll}\text { Component } & \text { Amount } \\ \text { Rotiphorese Gel } 30 & 0.83 \mathrm{ml} \\ 4 \mathrm{X} \text { Tris/SDS, pH } 6.8 & 1.25 \mathrm{ml} \\ \mathrm{ddH}_{2} \mathrm{O} & 2.86 \mathrm{ml} \\ 10 \% \text { APS } & 50 \mu \mathrm{l} \\ \text { TEMED } & 5 \mu 1\end{array}$

\section{$\underline{4 \mathrm{X} \text { Tris/SDS, } \mathrm{pH} 6.8}$}

For $100 \mathrm{ml}$

$\begin{array}{ll}\text { Tris base } & 6.05 \mathrm{~g} \\ \mathrm{SDS} & 0.4 \mathrm{~g} \\ \mathrm{ddH}_{2} \mathrm{O} & \text { to } 100 \mathrm{ml}\end{array}$

$\mathrm{pH}$ was adjusted with $37 \% \mathrm{HCl}$ to 6.8 ; the solution was stored at room temperature. 
$\underline{4 X \text { Tris/SDS, } \mathrm{pH} 8.8}$

$\begin{array}{ll} & \text { For } 250 \mathrm{ml} \\ \text { Tris base } & 45.5 \mathrm{~g} \\ \mathrm{SDS} & 1 \mathrm{~g} \\ \mathrm{ddH}_{2} \mathrm{O} & \text { to } 250 \mathrm{ml} \\ & \\ \mathrm{pH} \text { was adjusted with } 37 \% \mathrm{HCl} \text { to } 6.8 \text {; the solution was stored at room temperature. }\end{array}$

$\underline{\text { 5X SDS-PAGE running buffer }}$

$$
\text { For } 21
$$

Tris base $\quad 30.2 \mathrm{~g}$

Glycine $\quad 144 \mathrm{~g}$

SDS $10 \mathrm{~g}$

$\mathrm{ddH}_{2} \mathrm{O}$ to 21

$\mathrm{pH}$ was adjusted with $37 \% \mathrm{HCl}$ to 8.3 ; the solution was stored at room temperature.

1X SDS-PAGE running buffer

$\begin{array}{lll}5 \mathrm{X} \text { stock } & \text { For } 21 \\ \mathrm{ddH} \mathrm{H}_{2} \mathrm{O} & 400 \mathrm{ml} & \text { to } 21 \\ & & \\ 5 \mathrm{X} \text { transfer buffer } & \text { For } 21 & \\ & 39.4 \mathrm{~g} & \\ \text { Tris base } & 144 \mathrm{~g} & \\ \text { Glycine } & \text { to } 21 & \\ \text { ddH } \mathrm{H}_{2} \mathrm{O} & & \\ \text { pH was adjusted with } 37 \% \mathrm{HCl} \text { to } 8.3 ; \text { the solution was stored at room temperature. } \\ \end{array}$


$\underline{10 X \text { washing buffer }}$

\begin{tabular}{|c|c|c|}
\hline & \multicolumn{2}{|l|}{ For 21} \\
\hline Tris base & \multicolumn{2}{|l|}{$48.4 \mathrm{~g}$} \\
\hline $\mathrm{NaCl}$ & \multicolumn{2}{|l|}{$58.48 \mathrm{~g}$} \\
\hline $\mathrm{dd}_{2} \mathrm{O}$ & \multicolumn{2}{|l|}{ to 21} \\
\hline \multicolumn{3}{|c|}{$\mathrm{pH}$ was adjusted with $\mathrm{HCl}$ to 7.5 ; the solution was stored at room temperature } \\
\hline \multicolumn{3}{|c|}{$\underline{1 X}$ washing buffer } \\
\hline & For 51 & Final concentration \\
\hline $10 \mathrm{X}$ stock & $500 \mathrm{ml}$ & $1 \mathrm{X}$ \\
\hline Tween 20 & $5 \mathrm{ml}$ & $0.1 \%$ \\
\hline $\mathrm{ddH}_{2} \mathrm{O}$ & to 51 & \\
\hline
\end{tabular}

Blocking reagent

$\begin{array}{lll} & \text { For } 50 \mathrm{ml} & \text { Final concentration } \\ \text { Nonfat dry milk } & 2.5 \mathrm{~g} & 5 \% \\ \text { 1X washing buffer } & \text { to } 50 \mathrm{ml} & \end{array}$

The solution should be prepared freshly and can be stored at $4^{\circ} \mathrm{C}$ for $1-2$ days.

Antibody incubation buffer

$\begin{array}{lll} & \text { For } 50 \mathrm{ml} & \text { Final concentration } \\ 5 \% \text { nonfat milk } & 5 \mathrm{ml} & 0.5 \% \\ 1 \mathrm{X} \text { washing buffer } & \text { to } 50 \mathrm{ml} & \end{array}$

Primary antibodies were used in the following dilutions:

$\begin{array}{ll}\text { Antibody } & \text { Used dilution } \\ \text { Anti-Pan } \mathrm{Na}_{\mathrm{v}} \mathrm{Ab} & 1: 500 \\ \text { Anti-Na }_{\mathrm{v}} 1.5 \mathrm{Ab} & 1: 500 \\ \text { Anti-PLB } \mathrm{Ab} & 1: 10000 \\ \text { Anti-SERCA2a Ab } & 1: 20000\end{array}$


Anti-NCX Ab

Anti-Calsequestrin $\mathrm{Ab}$

Anti-GAPDH Ab

Secondary HRP-conjugated antibodies were used in the following dilutions:

Antibody

Used dilution

Donkey anti-rabbit whole IgG

$1: 10000$

Sheep anti-mouse whole $\operatorname{IgG}$

$1: 10000$

\subsection{Co-immunocytochemical analysis}

Immunocytochemical (ICC) staining is a technique used to detect a specific antigen (protein) in live or fixed cell cultures by use of specific primary antibodies which recognize the protein in the cell. A secondary antibody has a fluorescent molecule attached to it so that it can be detected by confocal microscopy.

ICC technique can be divided into four steps, such as cell preparation, fixation, antibody binding and detection.

\subsubsection{Preparation and fixation of cells}

Prior to plating the cells, chamber slides (4 well glass slide, Nunc/USA) were covered with M199/laminin mixture $(3 \mathrm{ml} / 30 \mu \mathrm{l})$ to ensure a better attachment of the cells to the bottom and incubated at $37^{\circ} \mathrm{C}$ for $1 \mathrm{~h}$ before use.

Ventricular cardiomyocytes isolated from rabbit were transfected with recombinant adenovirus encoding for HA-tagged $\mathrm{CaMKIII} \delta_{\mathrm{C}}$ (or $\beta$-gal as control) with a MOI of 100 directly in the suspension (1X10 cells in $4 \mathrm{ml}$ of M199) and plated on laminin-coated chamber slides. After the attachment phase of 3 hours, the medium was replaced with fresh M199 (4 ml per chamber slide) and cultured for 24 hours. The incubation of the cardiomyocytes was performed in gas-controlled incubator in water vapor saturated air containing $5 \% \mathrm{CO}_{2}$ at $37^{\circ} \mathrm{C}$. Ventricular cardiomyocytes isolated from CaMKII $\delta_{\mathrm{C}} \mathrm{TG}$ mouse were plated on laminin-coated chamber slides and incubated for 1 hour at room temperature to allow the cells to attach to the bottom. After incubation the rabbit and mouse myocytes were washed with 1X PBS (three times five minutes) and fixed. Fixation 
is needed to preserve cells in a reproducible and live-like manner. The rabbit myocytes were fixed with $4 \%$ paraformaldehyde for 30 minutes at room temperature. The mouse myocytes were fixed in ice-cold $100 \%$ ethanol for 20 minutes at $-20^{\circ} \mathrm{C}$. After fixation the cells were washed with 1X PBS (three times five minutes) and blocked with blocking solution overnight at $4^{\circ} \mathrm{C}$ to minimize nonspecific staining.

\subsubsection{Incubation with antibodies}

After blocking the myocytes were washed with 1X PBS (three times five minutes). Next, the cells were incubated with primary antibody diluted with the antibody dilution buffer for 1 hour at $37^{\circ} \mathrm{C}$ (for rabbit myocytes) and overnight at $4^{\circ} \mathrm{C}$ (for mouse myocytes). After washing with $1 \mathrm{X}$ PBS (six times five minutes), the cells were incubated with dye conjugated secondary antibody diluted in antibody dilution buffer for 2 hour at room temperature in darkness. Afterwards the cells were washed as before, covered with VECTASHIELD HardSet Mounting Medium (Vector Laboratories) and analyzed using an LSM 5 Pascal confocal microscope (Zeiss). For control, no primary antibody was used.

$\underline{4 \% \text { paraformaldehyde }}$

$\begin{array}{lll} & \text { For } 100 \mathrm{ml} & \text { Final concentration } \\ \text { Paraformaldehyde } & 4 \mathrm{~g} & 4 \% \\ 1 \mathrm{X} \text { PBS } & \text { to } 100 \mathrm{ml} & \end{array}$

$\underline{\text { Blocking reagent }}$

$\begin{array}{lll} & \text { For } 10 \mathrm{ml} & \text { Final concentration } \\ \text { BSA-V } & 100 \mathrm{mg} & 1 \% \\ 1 \mathrm{X} \text { PBS } & \text { to } 10 \mathrm{ml} & \end{array}$

The solution should be prepared freshly and can be stored at $4{ }^{\circ} \mathrm{C}$ for $1-2$ days.

Incubation buffer for primary antibody

$\begin{array}{lll} & \text { For } 10 \mathrm{ml} & \text { Final concentration } \\ \text { BSA-V } & 50 \mathrm{mg} & 0.5 \% \\ \text { Triton X-100 } & 75 \mu \mathrm{l} & 0.75 \% \\ 1 \mathrm{X} \text { PBS } & \text { to } 10 \mathrm{ml} & \end{array}$


Incubation buffer for secondary antibody

For $10 \mathrm{ml} \quad$ Final concentration

$\begin{array}{lll}\text { BSA-V } & 50 \mathrm{mg} & 0.5 \%\end{array}$

1X PBS to $10 \mathrm{ml}$

Primary antibodies were used in the following dilutions:

Antibody Used dilution

$\begin{array}{ll}\text { Anti-HA } & 1: 100\end{array}$

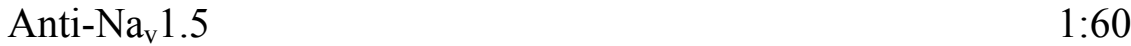

Secondary dye conjugated antibodies were used in the following dilutions:

$\begin{array}{ll}\text { Antibody } & \text { Used dilution } \\ \text { goat anti-mouse Texas Red-conjugated } & 1: 200 \\ \text { goat anti-rabbit Fluorescein-conjugated } & 1: 200 \\ \text { goat anti-rabbit Alexa Fluor 488 } & 1: 200 \\ \text { goat anti-mouse Alexa Fluor 555 } & 1: 200\end{array}$

\subsection{Back-phosphorylation}

\subsubsection{Immunoprecipitation of $\mathrm{Na}^{+}$channel from mouse cardiac homogenates}

Cardiac homogenate, prepared from WT mouse heart as described in 3.3.2, was split in 3 tubes with $1 \mathrm{mg}$ of total protein in each and suspended in the dilution media to bring the volume of each sample up to $500 \mu$ l. The samples were kept on ice for 30 minutes with occasional vortexing. After adding, $5 \mu \mathrm{g}$ of rabbit polyclonal anti-Pan $\mathrm{Na}_{\mathrm{v}}$ antibody (Pan $\mathrm{Na}^{+}$Channel, Alomone Labs), the samples were incubated using an end-over-end rotator set at low speed for 2 hours at $4^{\circ} \mathrm{C}$. Protein G-sepharose Fast Flow (Amersham Biosciences) was prepared as described in 3.4.2 and $100 \mu$ of the slurry was added to each sample. The mixture was gently mixed for 2 hours at $4{ }^{\circ} \mathrm{C}$ using an end-over-end rotator set at low speed. Subsequently, the matrix was sedimented by centrifugation for 30 seconds at 14000x g in an Eppendorf bench-top MiniSpin centrifuge. The supernatants were removed with a $29 \mathrm{G}$ cannula connected to a syringe and the pellets were washed 3 times with 500 $\mu 1$ of RIPA buffer. The tubes were inverted carefully 5 times to mix. After each washing step, the immunoprecipitates were recovered by centrifugation as described above. 
Immunoprecipitated $\mathrm{Na}^{+}$channels were resuspended in $1 \mathrm{X}$ CaMKII reaction buffer contained $50 \mathrm{mM}$ Tris-HCl, $10 \mathrm{mM} \mathrm{MgCl}_{2}, 2 \mathrm{mM}$ dithiothreitol, $0.1 \mathrm{mM} \mathrm{Na} \mathrm{EDTA}_{2} \mathrm{pH}$ 7.5 .

\subsubsection{Preactivation of endogenous CaMKII and immunoprecipitation of $\mathrm{Na}^{+}$ channels from rabbit myocytes}

Ventricular cardiomyocytes isolated from a rabbit were transfected with either CaMKII $\delta_{\mathrm{C}}$ or LacZ using a MOI of 100 as described in 3.2.1. Transfected myocytes were superfused with the relaxation solution for 5 minutes at room temperature. Afterwards, saponin $(50 \mu \mathrm{l} / \mathrm{ml})$ was added for 30 seconds to permeabilize the sarcolemma. After permeabilization, the myocytes were exposed to the internal solution. To prevent possible basal PKA activity, the PKA inhibitory peptide PKI (15 $\mu \mathrm{M}$, Sigma) was included in all bath solutions. After 5 minute equilibration, okadaic acid $(2 \mu \mathrm{M})$ was added to prevent dephosphorylation. To activate an endogenous CaMKII, the myocytes were incubated for 5 more minutes in the presence of $50 \mathrm{nM}$ or $500 \mathrm{nM}$ free $\mathrm{Ca}^{2+}$ in the latter case, $\mathrm{CaCl}_{2}$ concentration was raised with simultaneous addition of CaM (Upstate). Then myocytes were harvested and lysed in $500 \mu \mathrm{l}$ of dilution medium. Immunoprecipitation of $\mathrm{Na}^{+}$ channels were carried out as describe above.

\subsubsection{Preactivation of exogenous CaMKII and back-phosphorylation}

CaMKII (30 U, New England Biolabs Inc.) was preactivated either in the presence or absence of CaMKII inhibitors KN-93 (Seikagaku Corporation), AIP (Sigma), or PKA/PKC inhibitor cocktail (Upstate). Immunoprecipitated $\mathrm{Na}^{+}$channels from mouse and rabbit samples were phosphorylated with CaMKII for 30 minutes at $30^{\circ} \mathrm{C}$ in the presence of $[\gamma$ $\left.{ }^{32} \mathrm{P}\right]$-ATP with a specific activity of $5.7 \mathrm{Ci} / \mathrm{mmol}$. After washing the beads with $500 \mu \mathrm{l}$ of RIPA buffer, proteins were eluted by heating for 30 min at $37^{\circ} \mathrm{C}$ in $65 \mu 1$ of $2 \mathrm{X}$ sampler buffer and separated from the beads by centrifugation. The supernatants were resolved by SDS-7.5\% polyacrylamide gel, and phosphorylated proteins were visualized using a phosphoimager. 
Dilution medium (prepared just prior to use)

For $5 \mathrm{ml}$

Modified RIPA buffer

$200 \mathrm{mM} \mathrm{NaF}$

$100 \mathrm{mM} \mathrm{Na}_{3} \mathrm{VO}_{4}$

$100 \mathrm{mM}$ DTT

$10 \%$ CHAPS
$5 \mathrm{ml}$

$500 \mu 1$

$50 \mu 1$

$50 \mu 1$

$50 \mu 1$
Final concentration

$20 \mathrm{mM}$

$1 \mathrm{mM}$

$1 \mathrm{mM}$

$1 \%$

The complete protease inhibitor cocktail (Roche) was added.

$\underline{\text { Modified RIPA buffer }}$

$\begin{array}{lll} & \text { For } 50 \mathrm{ml} & \text { Final concentration } \\ 2 \mathrm{M} \mathrm{Tris-HCl}, \mathrm{pH} 7.4 & 1.25 \mathrm{ml} & 50 \mathrm{mM} \\ 4 \mathrm{M} \mathrm{NaCl} & 2.5 \mathrm{ml} & 200 \mathrm{mM} \\ \mathrm{ddH}_{2} \mathrm{O} & \text { to } 50 \mathrm{ml} & \\ & & \\ \text { Relaxation solution (prepared just prior to use) } & \text { For } 50 \mathrm{ml} & 10 \mathrm{mM} \\ & 5 \mathrm{ml} & 0.1 \mathrm{mM} \\ 100 \mathrm{mM} \mathrm{HEPES}, \mathrm{pH} 7.4 & 50 \mu 1 & 150 \mathrm{mM} \\ 100 \mathrm{mM} \mathrm{EGTA}^{\mathrm{M} \text { potassium aspartate }} & 3.75 \mathrm{ml} & 0.25 \mathrm{mM} \\ 1 \mathrm{M} \mathrm{MgCl} \mathrm{M}_{2} & 12.5 \mu \mathrm{l} & 5 \mathrm{mM} \\ 100 \mathrm{mM} \mathrm{Na}_{3} \text {-ATP } & 2.5 \mathrm{ml} & 10 \mathrm{mM}\end{array}$

Internal solution (prepared just prior to use)

$\begin{array}{lll} & \text { For } 50 \mathrm{ml} & \text { Final concentration } \\ 100 \mathrm{mM} \text { HEPES, pH 7.2 } & 5 \mathrm{ml} & 10 \mathrm{mM} \\ 100 \mathrm{mM} \text { EGTA } & 0.5 \mathrm{ml} & 1 \mathrm{mM} \\ 2 \mathrm{M} \mathrm{potassium} \mathrm{aspartate} & 3 \mathrm{ml} & 120 \mathrm{mM} \\ 1 \mathrm{M} \mathrm{MgCl}_{2} & 285 \mu \mathrm{m} & 5.7 \mathrm{mM}(1 \mathrm{mM} \text { free }[\mathrm{Mg}]) \\ 100 \mathrm{mM} \mathrm{Na}_{3} \text {-ATP } & 2.5 \mathrm{ml} & 5 \mathrm{mM} \\ 1 \mathrm{M} \mathrm{CaCl}_{2} & 12.5 \mu \mathrm{m} & 0.25 \mathrm{mM}\left(50 \mathrm{nM} \text { free }\left[\mathrm{Ca}^{2+}\right]\right) \\ 0.5 \mathrm{mM} \mathrm{PKI}^{2} & 15 \mu \mathrm{M} h i b i t o r y\end{array}$




$\begin{array}{lll}\text { Reduced glutathione } & 150 \mathrm{mg} & 10 \mathrm{mM} \\ \text { Creatine phosphokinase } & 5 \mathrm{mg} & 5 \mathrm{U} / \mathrm{ml} \\ \text { Phosphocreatine } & 138.9 \mathrm{mg} & 10 \mathrm{mM} \\ \text { Dextran (Mr. 40000) } & 2 \mathrm{mg} & 4 \%\end{array}$

$\underline{2 X}$ sampler buffer

$\begin{array}{lll} & \text { For } 20 \mathrm{ml} & \text { Final concentration } \\ \text { Tris-HCl } & 0.32 \mathrm{~g} & 100 \mathrm{mM} \\ \text { SDS } & 0.8 \mathrm{~g} & 4 \% \\ \text { Glycerol } & 4 \mathrm{ml} & 20 \%\end{array}$

\subsection{Isolation of mouse ventricular myocytes}

The isolation of mouse ventricular cardiomyocytes was performed using Langendorff perfusion apparatus. Before isolation, perfusion apparatus was washed two times with distilled water and then with perfusion buffer through the system for at least 5 min.

Mice were anesthetized in a gas chamber with $800 \mu \mathrm{l}$ of halothane (Eurime-Pharm GmbH). A cannula was inserted into the aorta and perfusion started with a flow rate of $3 \mathrm{ml} / \mathrm{min}$ for 4 minutes. Afterwards, the heart perfusion was continued with myocyte digestion buffer for 8 to 10 minutes at $3 \mathrm{ml} / \mathrm{min}$. After enzymatic digestion, the heart was cut from the cannula and placed in a $60-\mathrm{mm}$ dish containing $2.5 \mathrm{ml}$ of myocyte digestion buffer. The heart was cut in half and the ventricles were gently teased with fine forceps into several small pieces. These were then pipetted gently several times with a sterile plastic transfer pipette ( $2 \mathrm{~mm}$ opening). The cell suspension was transferred into a $15 \mathrm{ml}$ tube, $2.5 \mathrm{ml}$ of myocyte stopping buffer 1 was added and the heart tissue were continued to dissociate gently, using sterile plastic transfer pipettes with different size of openings $(2 \mathrm{~mm}, 1.5 \mathrm{~mm}$, and then $1 \mathrm{~mm}$ diameters) until all the large pieces of heart tissue were dispersed in the cell suspension. Next, the myocytes were sedimented by gravity for 8 to $10 \mathrm{~min}$ in the $15 \mathrm{ml}$ tube; the supernatant was transferred to a new $15 \mathrm{ml}$ tube and centrifuged for $1 \mathrm{~min}$ at $180 \mathrm{x}$ g. The pellet was resuspended in $5 \mathrm{ml}$ of myocyte stopping buffer 2 , combined with the gravity-sedimented myocytes and diluted with myocyte stopping buffer 2 to bring the total volume up to $10 \mathrm{ml}$. Other cell types and dead myocytes were removed by numerous steps of selective sedimentation under gravity (for about 10 minutes) in washing solution. 
Each portion of washing solution used for every subsequent sedimentation-resuspension cycle contained $\mathrm{Ca}^{2+}$ at gradually rising concentrations, reaching the concentration of 0.8 $\mathrm{mM}$ in the final washing, which is close to that in the medium $(1 \mathrm{mM})$ used for further cell measurements.

10X Perfusion buffer

$\mathrm{NaCl}$

$\mathrm{KCl}$

$\mathrm{KH}_{2} \mathrm{PO}_{4}$

$\mathrm{Na}_{2} \mathrm{HPO}_{4} \cdot 2 \mathrm{H}_{2} \mathrm{O}$

$\mathrm{MgSO}_{4} \cdot 7 \mathrm{H}_{2} \mathrm{O}$

Phenol-red

$\mathrm{NaHCO}_{3}$

$\mathrm{KHCO}_{3}$

HEPES

Taurine

The buffer was stored $+4^{\circ} \mathrm{C}$

BDM

For $1 \mathrm{~L}$

$50.5 \mathrm{mg}$

to $1 \mathrm{~L}$

$\mathrm{ddH}_{2} \mathrm{O}$
Final concentration

$65.992 \mathrm{~g}$

$1.13 \mathrm{M}$

$3.506 \mathrm{~g}$

$47 \mathrm{mM}$

$816.6 \mathrm{mg}$

$6 \mathrm{mM}$

$1067.9 \mathrm{mg}$

$6 \mathrm{mM}$

$2958.0 \mathrm{mg}$

$12 \mathrm{mM}$

$120.4 \mathrm{mg}$

$0.32 \mathrm{mM}$

$10.080 \mathrm{~g}$

$120 \mathrm{mM}$

$10.100 \mathrm{~g}$

$100 \mathrm{mM}$

$23.831 \mathrm{~g}$

$100 \mathrm{mM}$

$37.530 \mathrm{~g}$

$300 \mathrm{mM}$

Final concentration

The solution was stored $+4^{\circ} \mathrm{C}$

$\underline{1 X \text { Perfusion buffer }}$

For $1 \mathrm{~L}$

$100 \mathrm{ml}$

$20 \mathrm{ml}$

$0.991 \mathrm{~g}$
$500 \mathrm{mM}$

Final concentration

$1 \mathrm{X}$

$10 \mathrm{mM}$

$5.5 \mathrm{mM}$

$\mathrm{pH}$ was adjusted with $\mathrm{NaOH}$ to 7.46 at $37^{\circ} \mathrm{C}$. The buffer was stored $+4^{\circ} \mathrm{C}$ 
Myocyte digestion buffer

\begin{tabular}{|c|c|c|}
\hline & For $18 \mathrm{ml}$ & Final concentration \\
\hline 1X Perfusion buffer & $18 \mathrm{ml}$ & \\
\hline Liberase Blendzyme 1 & $4.5 \mathrm{mg}$ & \\
\hline Trypsin & $100.08 \mu 1$ & \\
\hline $10 \mathrm{mM} \mathrm{CaCl}_{2}$ & $22.5 \mu 1$ & $1.25 \mathrm{mM}$ \\
\hline \multicolumn{3}{|l|}{ Myocyte stopping buffer 1} \\
\hline & For $2.5 \mathrm{ml}$ & Final concentration \\
\hline 1X Perfusion buffer & $2.25 \mathrm{ml}$ & \\
\hline BCS (Bovine calf serum) & $0.25 \mathrm{ml}$ & $10 \%$ \\
\hline $10 \mathrm{mM} \mathrm{CaCl}_{2}$ & $3.125 \mu 1$ & $1.25 \mathrm{mM}$ \\
\hline
\end{tabular}

Myocyte stopping buffer 2

For $20 \mathrm{ml} \quad$ Final concentration

1X Perfusion buffer $\quad 19 \mathrm{ml}$

BCS (Bovine calf serum) $\quad 1 \mathrm{ml} \quad 5 \%$

$10 \mathrm{mM} \mathrm{CaCl}_{2} \quad 25 \mathrm{ml} \quad 1.25 \mathrm{mM}$

Washing solution

\begin{tabular}{|c|c|c|c|c|}
\hline & & $\# 1$ & $\# 2$ & $\# 3$ \\
\hline 1X Perfusion & buffer & $5 \mathrm{ml}$ & $5 \mathrm{ml}$ & $10 \mathrm{ml}$ \\
\hline
\end{tabular}

(with 5\% BCS)

$100 \mathrm{mM} \mathrm{CaCl}_{2} \quad 5 \mu \mathrm{l} \quad 10 \mu \mathrm{l} \quad 40 \mu \mathrm{l} \quad 80 \mu \mathrm{l}$
$(0.1 \mathrm{mM})$
$(0.2 \mathrm{mM})$
$(0.4 \mathrm{mM})$
$(0.8 \mathrm{mM})$

\subsection{Measurement of cell shortening and $\mathrm{Ca}^{2+}$ transients using an epifluorescence microscope}

Evaluation of global excitation-contraction coupling was performed in isolated single ventricular cardiac myocytes. These were obtained by enzymatic digestion of the explanted hearts via Langendorff perfusion apparatus using a digestion buffer as described in Methods 3.8. 
Experiments to evaluate E-C coupling was performed to determine whether increased stimulation rates lead to changes in fractional shortening of myocytes (i.e. force-frequency relationship) and whether this may be due to altered intracellular $\mathrm{Ca}^{2+}$. Therefore, cell shortening was measured in parallel with estimation of the intracellular $\mathrm{Ca}^{2+}$ concentration by a $\mathrm{Ca}^{2+}$-fluorescent dye at different stimulation frequencies. Application of caffeine is one of the most useful methods to assess SR $\mathrm{Ca}^{2+}$ load. Rapid application of caffeine opens the RyR2 channels thereby releasing all calcium ions, which are stored in the SR. The amplitude of the caffeine induced $\mathrm{Ca}^{2+}$ transient was used to calculate total $\mathrm{SR} \mathrm{Ca}^{2+}$ content.

Isolated cardiomyocytes were plated on laminin-coated IonOptix chamber for 15 minutes to allow the cells to attach. The washing solution was removed and replaced with $200 \mu 1$ of $\mathrm{Ca}^{2+}$-fluorescent dye Fluo-3 by incubation with $10 \mu \mathrm{M}$ of the acetoxymethyl ester (AM) form of the dye (Molecular Probes) for $15 \mathrm{~min}$ at room temperature in darkness. The chamber was placed into the microscope holder. After loading, the cells were washed with normal 1X Tyrode solution containing $1 \mathrm{mM} \mathrm{Ca}^{2+}$ at $37^{\circ} \mathrm{C}$ at a flow rate of $80 \mathrm{ml} / \mathrm{h}$ for 5 minutes using the superfusion system. This also allows for deesterification of the dye. The image of the myocytes was recorded using a camera (MyoCam) and displayed on a monitor. The dye was excited with a wavelength at $480 \pm 15 \mathrm{~nm}$ using a $75 \mathrm{~W}$ xenon arc lamp (Ushio, Japan) on the stage of a Nikon Eclipse TE200-U inverted microscope. Emitted fluorescence was measured using a photomultiplier (at $535 \pm 20 \mathrm{~nm}$; IonOptix Corp, Milton, Mass). From the raw fluorescence, $\mathrm{F} / \mathrm{F}_{0}$ was calculated by dividing it by the baseline fluorescence $\left(\mathrm{F}_{0}\right)$, after subtraction of background fluorescence. Myocytes were field-stimulated (voltage $25 \%$ above the threshold) at $1 \mathrm{~Hz}$ and $37^{\circ} \mathrm{C}$ until steady-state was achieved and only those cells exhibiting stable steady-state contractions were included in the study. Cells were transilluminated by red light $(>650 \mathrm{~nm}$, to avoid interference with Fluo-3 epifluorescence measurement), and shortening was measured using a sarcomere length detection system (IonOptix Corp, Milton, Mass). After steady-state conditions were achieved, stimulation frequency was increased stepwise from $1 \mathrm{~Hz}$ to 2,4 and $8 \mathrm{~Hz}$. SR $\mathrm{Ca}^{2+}$ content was estimated by rapid application of a $10 \mathrm{mM}$ caffeine pulse to cause SR $\mathrm{Ca}^{2+}$ release. Diastolic $\mathrm{Ca}^{2+}$ was measured in cardiomyocytes loaded with $10 \mu \mathrm{M}$ Fura-2 AM (Sigma): excitation was performed at $340 \mathrm{~nm}$ as well as $380 \mathrm{~nm}$ and emission was recorded at $510 \mathrm{~nm}$. The obtained values were used to calculate $\mathrm{Ca}^{2+}$ transient amplitude in Fluo-3 experiments as described before (Maier et al., 2003). 
10X Tyrode

$\begin{array}{lll} & \text { For } 1 \mathrm{~L} & \text { Final concentration } \\ \mathrm{KCl} & 2.982 \mathrm{~g} & 40 \mathrm{mM} \\ \mathrm{NaCl} & 81.816 \mathrm{~g} & 1.4 \mathrm{M} \\ \mathrm{MgCl}_{2} & 0.952 \mathrm{~g} & 10 \mathrm{mM} \\ \mathrm{HEPES} & 11.916 \mathrm{~g} & 50 \mathrm{mM}\end{array}$

$\mathrm{pH}$ was adjusted with $\mathrm{NaOH}$ to 7.00 . The tyrode was stored $+4^{\circ} \mathrm{C}$

$\underline{1 X}$ Tyrode supplemented with $1 \mathrm{mM} \mathrm{Ca}^{2+}$

$\begin{array}{lll} & \text { For } 1 \mathrm{~L} & \text { Final concentration } \\ \text { 10X Tyrode } & 100 \mathrm{ml} & \\ \text { Glucose } & 1.802 \mathrm{~g} & 10 \mathrm{mM} \\ 1 \mathrm{M} \mathrm{CaCl}_{2} & 1 \mathrm{ml} & 1 \mathrm{mM} \\ \mathrm{pH} \text { was adjusted with NaOH to } 7.54 \text { at room temperature. The tyrode was stored }+4^{\circ} \mathrm{C} \\ & & \\ 1 \mathrm{X} \text { Tyrode with caffeine } & & \text { Final concentration } \\ & & \\ 1 \mathrm{X} \text { Tyrode } & 100 \mathrm{ml} 100 \mathrm{ml} & 10 \mathrm{mM} \\ \text { Caffeine } & 194 \mathrm{mg} & \end{array}$

Fluo-3 AM

For $5 \mathrm{ml} \quad$ Final concentration

1X Tyrode $5 \mathrm{ml}$

$1 \mathrm{mM}$ Fluo-3 AM $\quad 50 \mu \mathrm{l} \quad 10 \mathrm{mM}$

$\begin{array}{ll}\text { Pluronic F-127 } & 5 \mu 1\end{array}$

The solution was dispensed into $200 \mu \mathrm{l}$ aliquots and stored at $-20^{\circ} \mathrm{C}$ in darkness.

Fura-2 AM

For $5 \mathrm{ml} \quad$ Final concentration

1X Tyrode $5 \mathrm{ml}$

$1 \mathrm{mM}$ Fura-2 AM $\quad 50 \mu \mathrm{l} \quad 10 \mathrm{mM}$

Pluronic F-127 $5 \mu 1 \quad 2 \%$ 
The solution was dispensed into $200 \mu \mathrm{l}$ aliquots and stored at $-20^{\circ} \mathrm{C}$ in darkness.

\subsection{Measurement of the $\mathrm{Ca}^{2+}$ sparks using confocal microscope}

Isolated mouse cardiomyocytes were plated on laminin-coated chamber for 15 minutes to allow the cells to attach. The washing solution was removed and replaced with $200 \mu 1$ of $\mathrm{Ca}^{2+}$-fluorescent dye Fluo-4 by incubation with $10 \mu \mathrm{M}$ of the acetoxymethyl ester (AM) form of the dye (Molecular Probes) for $15 \mathrm{~min}$ at room temperature in darkness. After 15 minutes the loading buffer was exchanged for normal $1 \mathrm{X}$ Tyrode solution containing 3 $\mathrm{mM} \mathrm{Ca}{ }^{2+}$ at room temperature to deesterify Fluo-4 AM before recording the fluorescence. $\mathrm{Ca}^{2+}$ sparks were recorded using a laser scanning confocal microscope (LSM 5 Pascal, Zeiss) with a $40 \times$ oil-immersion objective. During the recording, the intact myocytes were continuously perfused with experimental solution. Fluo-4 AM was excited via an argon laser at $488 \mathrm{~nm}$ and emitted fluorescence was collected through a $515 \mathrm{~nm}$ long-pass emission filter. Fluorescence images were recorded in line-scan mode with 512 pixels per line, pixel time $0,64 \mu \mathrm{s}$, pixel size $0,07 \mu \mathrm{m} \times 0.07 \mu \mathrm{m}$, width of the scan $38,4 \mu \mathrm{m}$. $\mathrm{Ca}^{2+}$ spark frequency $(\mathrm{CaSpF})$ was measured during $0.5 \mathrm{~Hz}$ stimulation and normalized to cell volume and scan rate as sparks $\left(\mathrm{pl}^{-1} * \mathrm{~s}^{-1}\right)$. Peak of $\mathrm{Ca}^{2+}$ sparks were normalized as $\mathrm{F} / \mathrm{F}_{0}\left(\mathrm{~F} / \mathrm{F}_{0}\right.$ was calculated by dividing by the baseline fluorescence $F_{0}$, after subtraction of the background fluorescence), and duration was taken from the full-duration half-maximum (FDHM).

10X Tyrode

For $1 \mathrm{~L} \quad$ Final concentration

$\mathrm{KCl} 2.982 \mathrm{~g} \quad 40 \mathrm{mM}$

$\mathrm{NaCl} \quad 81.816 \mathrm{~g} \quad 1.4 \mathrm{M}$

$\begin{array}{lll}\mathrm{MgCl}_{2} & 0.952 \mathrm{~g} & 10 \mathrm{mM}\end{array}$

HEPES $11.916 \mathrm{~g} \quad 50 \mathrm{mM}$

$\mathrm{pH}$ was adjusted with $\mathrm{NaOH}$ to 7.00 . The tyrode was stored $+4^{\circ} \mathrm{C}$ 
$\underline{1 X}$ Tyrode supplemented with $3 \mathrm{mM} \mathrm{Ca}^{2+}$

\begin{tabular}{|c|c|c|}
\hline & For $1 \mathrm{~L}$ & Final concentra \\
\hline 10X Tyrode & $100 \mathrm{ml}$ & \\
\hline Glucose & $1.802 \mathrm{~g}$ & $10 \mathrm{mM}$ \\
\hline $1 \mathrm{M} \mathrm{CaCl}_{2}$ & $3 \mathrm{ml}$ & $3 \mathrm{mM}$ \\
\hline \multicolumn{3}{|c|}{$\mathrm{pH}$ was adjusted with $\mathrm{NaOH}$ to 7.4 at room temperature. The tyrode was stored +4} \\
\hline \multicolumn{3}{|l|}{$\underline{\text { Fluo-4 AM }}$} \\
\hline \multicolumn{2}{|r|}{ For $5 \mathrm{ml}$} & Final concentration \\
\hline 1X Tyrode & $4.56 \mathrm{ml}$ & \\
\hline $1 \mathrm{mM}$ Fluo-3 AM & $45.6 \mu 1$ & $10 \mathrm{mM}$ \\
\hline Pluronic F-127 & $4.56 \mu 1$ & $2 \%$ \\
\hline
\end{tabular}

The solution was dispensed into $200 \mu \mathrm{l}$ aliquots and stored at $-20^{\circ} \mathrm{C}$ in darkness

\subsection{Echocardiographic measurements}

Echocardiography was performed using a Visual Sonic 770 system with a $30 \mathrm{MHz}$ transducer. Mice were anesthetized by intraperitoneal injection of $2.5 \%$ Avertin $(5 \mu 1$ per gram of body weight). M-mode was recorded at a sweep speed of $150 \mathrm{~mm} / \mathrm{sec}$ with the cursor placed in the middle of the LV cavity. Measurements were obtained by an examiner blinded to the genotype of the animals.

\subsection{Statistical analysis}

All data are presented as mean \pm SEM. Statistical analyses were performed using Student's $t$-test for unpaired values or the two-way analysis of variance (ANOVA) for repeated measurements combined with post-hoc (Student-Newman-Keuls or Fisher-LSD) tests where appropriate. Values of $\mathrm{P}<0.05$ were considered as statistically significant. 


\section{Results}

\subsection{Association with and phosphorylation of $\mathrm{Na}^{+}$channels by $\mathrm{CaMKII}$}

\subsubsection{CaMKII associates with $\mathrm{Na}^{+}$channels}

To determine whether $\mathrm{CaMKII} \delta_{\mathrm{C}}$ associates with $\mathrm{Na}^{+}$channel, co-immunoprecipitation technique was performed.

As a starting material for co-immunoprecipitation, Triton X-100-solubilized cardiac homogenates, prepared from CaMKII $\delta_{\mathrm{C}} \mathrm{TG}$ and WT mouse hearts as well as lysates, prepared from rabbit ventricular myocytes transfected with CaMKIII $\delta_{\mathrm{C}}$ using a MOI of 100 for 24 hours were used.

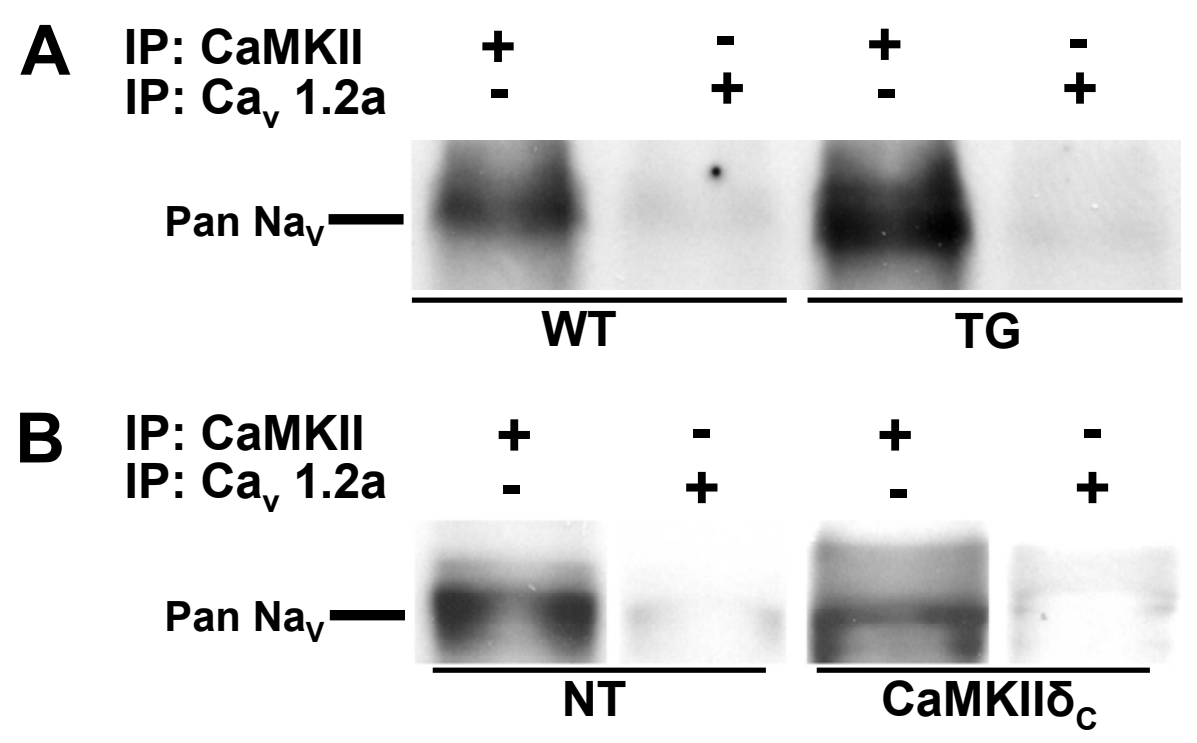

Figure 7. Association of CaMKII with all $\mathrm{Na}^{+}$channel isoforms $\left(\mathrm{Pan} \mathrm{Na}_{\mathrm{v}}\right)$ in Triton X-100solubilized cardiac mouse homogenate and rabbit lysates. The Triton X-100-solubilized (A) homogenate from mouse hearts and (B) lysates from rabbit ventricular myocytes were subjected to immunoprecipitation with either anti-CaMKII or anti-Ca $a_{v} 1.2 \mathrm{a} \mathrm{Ab}$, the immunoprecipitates were electrophoretically separated on $7.5 \%$ gel; detection of $\mathrm{Na}^{+}$channel bands was conducted by Western blot analysis with anti-Pan $\mathrm{Na}_{\mathrm{v}} \mathrm{Ab}$. CaMKII immunoprecipitation showed CaMKII association with the $\mathrm{Na}^{+}$channel in WT and TG hearts $\left(\mathrm{n}=3\right.$ and $\mathrm{n}=3$, respectively). $\mathrm{No}^{+}$ channel was co-immunoprecipitated when anti-Ca $\mathrm{a}_{\mathrm{v}} 1.2 \mathrm{a}$ antibody was used. Similar results were seen in rabbit myocytes $\left(\mathrm{CaMKII} \delta_{\mathrm{C}}\right.$ and nontransfected cells, $\mathrm{n}=4$ and $\mathrm{n}=4$, respectively). 
CaMKII was immunoprecipitated from both cardiac homogenates and lysates using a rabbit polyclonal anti-CaMKII antibody (Santa Cruze Biotechnology). The immunoprecipitates were subjected to Western blotting with rabbit polyclonal anti-Pan $\mathrm{Na}_{\mathrm{v}}$ antibody (Alomone Labs) and revealed an immunoreactive band at $\sim 250 \mathrm{kDa}$ (Fig. 7). Anti-Pan $\mathrm{Na}_{\mathrm{v}}$ antibody recognizes all $\mathrm{Na}^{+}$channel isoforms, therefore western blotting of the immunoprecipitates was repeated with cardiac-specific anti- $\mathrm{Na}_{\mathrm{v}} 1.5$ antibody, showing similar results (Fig. 8). To confirm the specificity of interaction between CaMKII and $\mathrm{Na}^{+}$

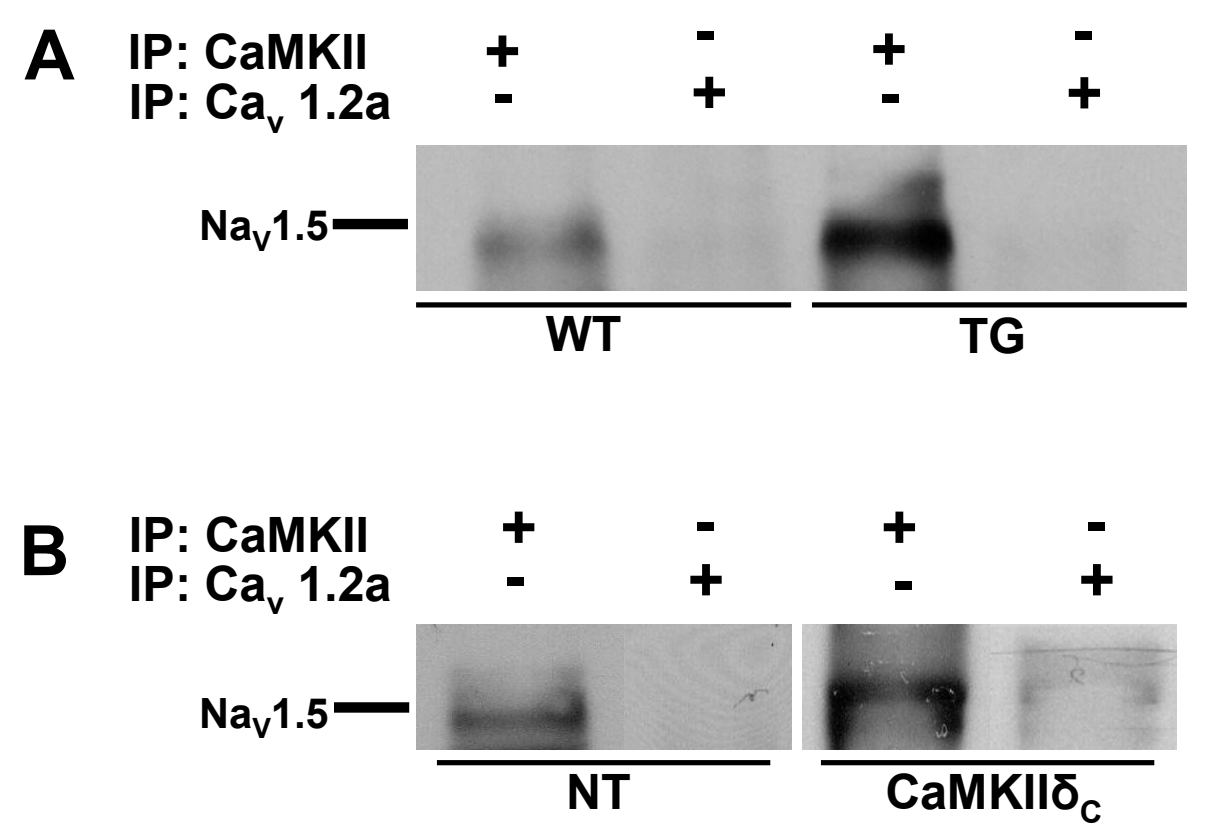

Figure 8. Association of CaMKII with the cardiac $\mathrm{Na}^{+}$channel isoform $\left(\mathrm{Na}_{\mathrm{v}} 1.5\right)$ in Triton $\mathrm{X}$ 100-solubilized cardiac mouse homogenate and rabbit lysates. The Triton X-100-solubilized (A) homogenate from mouse hearts and (B) lysates from rabbit ventricular myocytes were subjected to immunoprecipitation with either anti-CaMKII or anti-Ca $\mathrm{v}_{\mathrm{v}} 1.2 \mathrm{a} \mathrm{Ab}$, the immunoprecipitates were electrophoretically separated on $7.5 \%$ gel; detection of $\mathrm{Na}^{+}$channel bands was conducted by Western blot analysis with anti-Na $1.5 \mathrm{Ab}$. CaMKII immunoprecipitation showed CaMKII association with the $\mathrm{Na}^{+}$channel in WT and TG hearts $(n=3$ and $n=3$, respectively), while there was no co-immunoprecipitation of the $\mathrm{Na}^{+}$channel in control reactions performed with anti-Ca $1.2 \mathrm{a}$ antibody. Similar results were seen in rabbit myocytes $\left(\mathrm{CaMKII} \delta_{\mathrm{C}}\right.$ and nontransfected cells, $n=4$ and $n=4$, respectively). 
channel, the following negatives controls were included: incubation of the samples with antibody against L-type $\mathrm{Ca}^{2+}$ channel $\left(\mathrm{Ca}_{\mathrm{v}} 1.2 \mathrm{a}\right.$, Alomone Labs), which is known neither to associate with $\mathrm{Na}^{+}$channel nor does it lead to its precipitation (Fig. $7 \& 8 \mathrm{~A}$ and $7 \& 8 \mathrm{~B}$, lanes 2 and 4); incubation of the samples with protein G-sepharose beads alone. As expected, noprecipitation of the $\mathrm{Na}^{+}$channel was observed under these conditions (data not shown). Thus, co-immunoprecipitation experiments showed an association of CaMKII with $\mathrm{Na}^{+}$ channel in WT and $\mathrm{CaMKII}_{\mathrm{C}} \mathrm{TG}$ mouse hearts as well as in transfected and nontransfected rabbit myocytes.

\subsubsection{Immunocolocalization of CaMKII and $\mathrm{Na}^{+}$channels in single cardiomyocytes}

The special relationship between $\mathrm{CaMKII} \delta_{\mathrm{C}}$ and the $\mathrm{Na}^{+}$channel was confirmed with double labeling immunocytochemical techniques combined with laser scanning confocal microscopy. For this study ventricular cardiomyocytes from CaMKIII $\delta_{\mathrm{C}}$ transgenic mouse hearts as well as ventricular cardiomyocytes from rabbit hearts transfected with recombinant adenovirus carrying $\mathrm{CaMKII} \delta_{\mathrm{C}}$ (or $\beta$-gal as control) with MOI of 100 for 24 hours were used. Immunofluorescence images of each protein were obtained in the same cell. After fixation, the cardiomyocytes were incubated simultaneously with two different antibodies that recognize overexpressed HA-tagged CaMKII $\delta_{\mathrm{C}}$ (anti-HA, Roche) and the cardiac $\mathrm{Na}^{+}$channel (anti-Na 1.5 , Alomone Labs) to determine their subcellular localization. Only cardiomyocytes with the normal rod-shaped morphology were analyzed. Cardiac $\mathrm{Na}^{+}$channels was observed at high density in the transverse tubular membrane system (shown in green) in both mouse and rabbit myocytes, whereas CaMKII $\delta_{\mathrm{C}}$ was concentrated in the cytoplasm of the isolated cardiomyocytes (depicted in red) from both species (Fig. 9). Co-localization was established when identical regions contained both proteins. Double labeling of $\mathrm{Na}_{\mathrm{v}} 1.5$ and HA-tag revealed significant co-localization of cardiac $\mathrm{Na}^{+}$channels with the cytosolic isoform of CaMKII $\delta_{\mathrm{C}}$ (yellow) in transverse tubular membrane system in both mouse and rabbit cardiomyocytes. Apart of the membrane-associated $\mathrm{CaMKII} \delta_{\mathrm{C}}$, which overlapped with cardiac $\mathrm{Na}^{+}$channels, free CaMKII $\delta_{C}$ was also observed in numerous small foci in cytosol. To determine the degree of non-specific binding, negatives controls were included: incubation of the rabbit controltransfected myocytes with anti-HA antibody as well as incubation of the myocytes with secondary antibody alone. In both cases, no signal above background was detected (data not shown). 

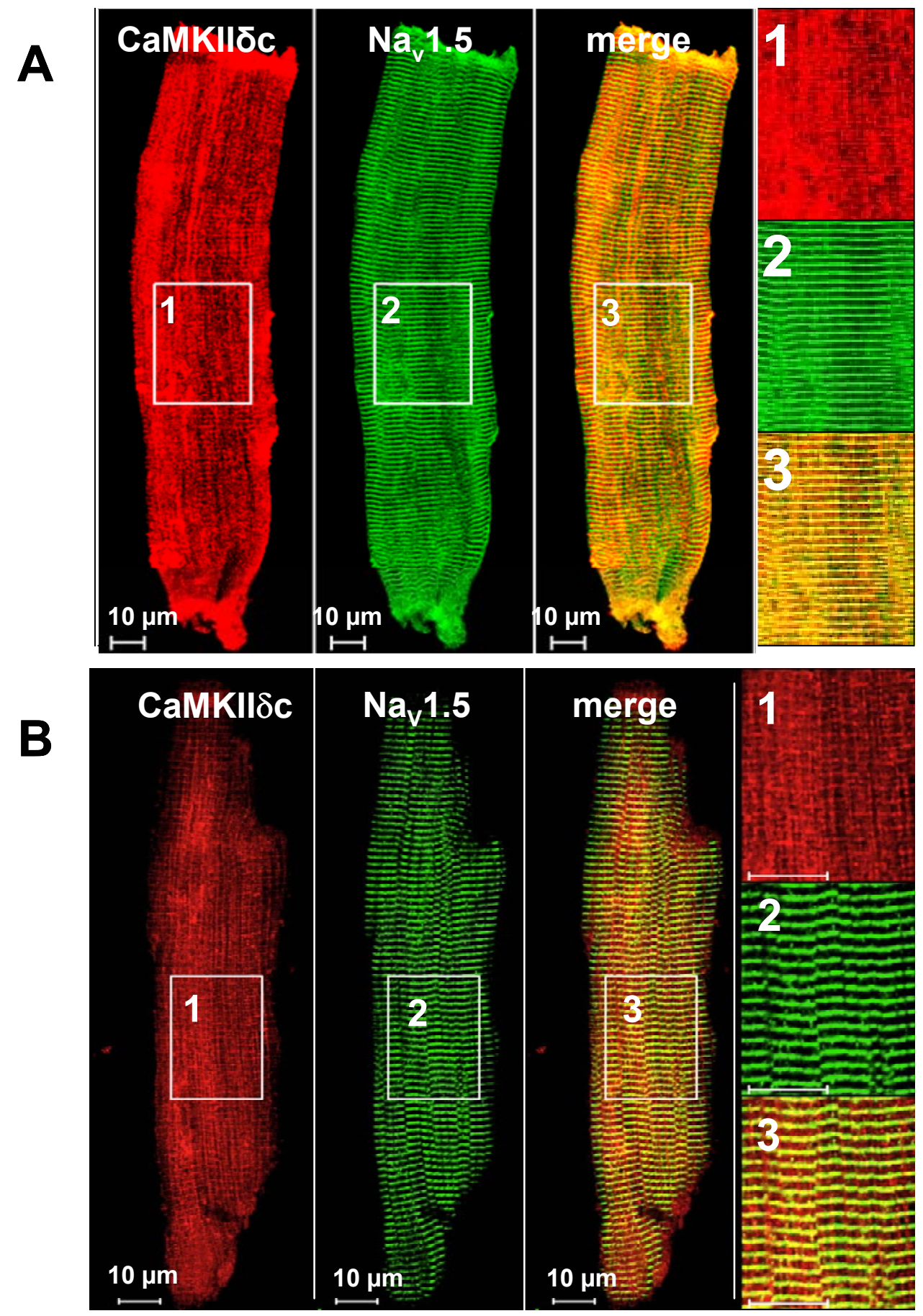

Figure 9. Co-localization of CaMKII and $\mathrm{Na}^{+}$channels in mouse and rabbit cardiomyocytes. Simultaneous labeling of CaMKII and $\mathrm{Na}^{+}$channels in ventricular myocytes from mouse (A) and rabbit (B) with primary anti-HA and anti- $\mathrm{Na}_{\mathrm{v}} 1.5$ antibodies followed by visualization of their localization with dye-conjugated secondary antibodies using laser scanning confocal microscopy. (A and $\mathbf{B}$ lane 1) single labeling of CaMKII $\delta_{\mathrm{C}}$ (red), concentrated in the cytoplasm of the isolated cardiomyocytes of both species. (A and $\mathbf{B}$ lane 2) single labeling of $\mathrm{Na}^{+}$channels (green), observed in the transverse tubular membrane system. (A and B lane 3) double staining, illustrating colocalization of CaMKII and $\mathrm{Na}^{+}$channels in transverse tubular in both mouse and rabbit cardiomyocytes (yellow). 


\subsubsection{CaMKII-dependent phosphorylation of $\mathrm{Na}^{+}$channels}

Phosphorylation is the most frequent protein post translational modification regulating its function. To assess whether CaMKII phosphorylates $\mathrm{Na}^{+}$channels, a back-phosphorylation assay with purified CaMKII and $\left[\gamma-{ }^{32} \mathrm{P}\right]$-ATP was utilized.

At first, phosphorylation of $\mathrm{Na}^{+}$channels by CaMKII was proven in WT mouse myocardium (Fig. 10A and B), because in CaMKII $\delta_{\mathrm{C}}$ TG mice $\mathrm{Na}^{+}$channels might have been already nearly maximally phosphorylated and therefore not available for phosphorylation by exogenous CaMKII during our back-phosphorylation assay. CaMKII activation mix containing buffer supplemented with $\mathrm{Ca}^{2+} / \mathrm{CaM}$ and $\mathrm{Mg}^{2+} / \mathrm{ATP}$ was prepared. To all samples (except tube 2) CaMKII was added and all tubes were incubated for 10 minutes at $30^{\circ} \mathrm{C}$ to allow activation of the enzyme. Subsequently these mixtures were transferred to the beads containing material immunoprecipitated with anti-Pan $\mathrm{Na}_{\mathrm{v}}$ antibody (Alomone Labs). Radioactive ATP was added and back-phosphorylation was carried out. Exogenous CaMKII clearly phosphorylated $\mathrm{Na}^{+}$channels (Fig 10A lane 1), and this effect was inhibited when KN-93 or AIP (known CaMKII inhibitors) were included (Fig. 10A lane 3 and 4), but not when PKA and PKC were blocked (Fig. 10B lane 2). In Figure 10A lane 2 immunoprecipitated materials were treated like other samples in the presence of $\mathrm{Ca}^{2+} / \mathrm{CaM}$ and $\mathrm{Mg}^{2+} / \mathrm{ATP}$ but without exogenous CaMKII. However, no significant incorporation was found. If CaMKII association with the $\mathrm{Na}^{+}$channels leads to CaMKII-dependent phosphorylation, then one would expect that addition of $\mathrm{Ca}^{2+} / \mathrm{CaM}$ and $\mathrm{Mg}^{2+} /$ ATP to the immunoprecipitated $\mathrm{Na}^{+}$channels would lead to channel phosphorylation without any need for exogenous CaMKII (since CaMKII should already be part of the complex). There might be several reasons why significant back-phosphorylation with $\mathrm{Ca}^{2+} / \mathrm{CaM}$ and $\mathrm{Mg}^{2+} / \mathrm{ATP}$ alone was never seen in our experiments: a) it is likely that those $\mathrm{Na}^{+}$channels to which endogenous CaMKII was attached were already phosphorylated. Since the $\mathrm{Na}^{+}$channels were not de-phosphorylated prior to back-phosphorylation, only free, unphosphorylated $\mathrm{Na}^{+}$channels were subject to exogenous CaMKII phosphorylation and visible via ${ }^{32} \mathrm{P}$ incorporation; b) our immunoprecipitation was done in the presence of $20 \mathrm{mM}$ NaF-an unspecific enzyme inhibitor-which was washed away just before adding the exogenous CaMKII (so the activity of endogenous CaMKII might have been decreased dramatically); c) the amount of active endogenous enzyme in our immunoprecipitate was probably too low to allow significant phosphorylation. It is noteworthily that the conditions for immunoprecipitation with anti- $\mathrm{Pan} \mathrm{Na}_{\mathrm{v}}$ antibody were different from that used for 


\section{Direct ${ }^{32} \mathrm{P}$ incorporation}

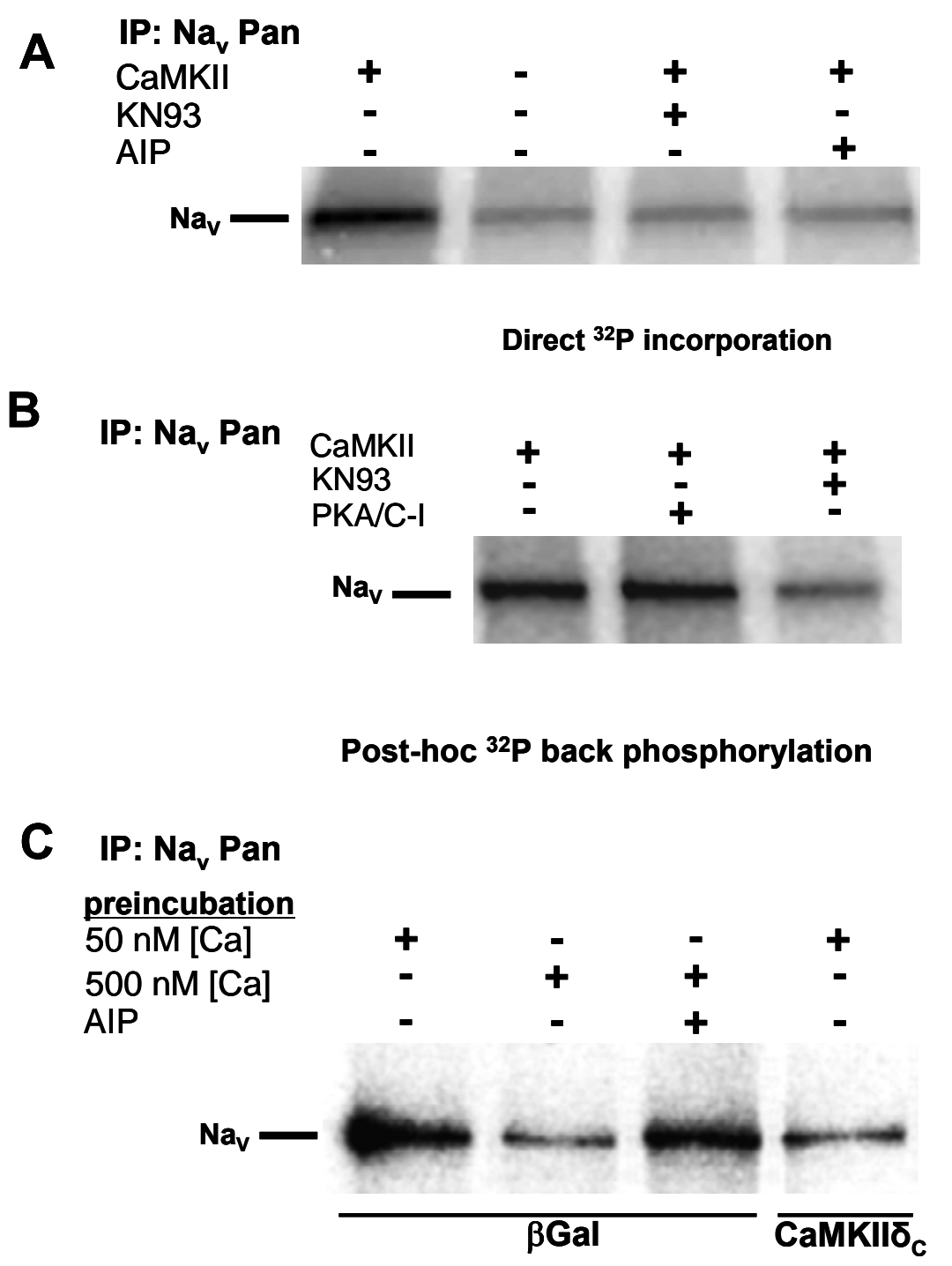

Fifure 10. Phosphorylation of $\mathrm{Na}^{+}$channel in cardiac mouse homogenate and rabbit lysates by either exogenous or endogenous CaMKII. (A and B) $\mathrm{Na}^{+}$channel was immunoprecipitated from WT mouse hearts (n=3) with anti-Pan $\mathrm{Na}_{\mathrm{v}} \mathrm{Ab}$ and directly phosphorylated with or without addition of exogenous CaMKII, KN-93, AIP or PKA/PKC inhibitor cocktail (PKA/C-1). (C) Endogenous CaMKII-dependent $\mathrm{Na}^{+}$channel phosphorylation was activated in permeabilized rabbit myocytes by preincubating them for 5 minutes in internal solutions of $500 \mathrm{nM}\left[\mathrm{Ca}^{2+}\right]$ plus 2 $\mu \mathrm{M} \mathrm{CaM}$ (versus $50 \mathrm{nM}\left[\mathrm{Ca}^{2+}\right]$ ). Sites not already phosphorylated were subsequently backphosphorylated in $\mathrm{Na}^{+}$channel immunoprecipitates from mouse and rabbit samples by exogenous preactivated CaMKII and $\left[\gamma_{-}{ }^{32} \mathrm{P}\right]-\mathrm{ATP}$. Phosphorylation of $\mathrm{Na}^{+}$channel was quantified using a phosphoimager. 
co-immunoprecipitation with anti-CaMKII antibody and included a higher salt concentration (to gain more pure preparation of $\mathrm{Na}^{+}$channels) and two additional washes with CaMKII buffer to bring the immunoprecipitated material into conditions suitable for back-phosphorylation. Since CaMKII is likely to associate with $\mathrm{Na}^{+}$channels only transiently, it might have been largely lost during the immunoprecipitation, performed under these more stringent conditions. However, because the amount and activity of CaMKII $\delta_{C}$ as well as the phosphorylation level of $\mathrm{Na}^{+}$channels in immunoprecipitates were difficult to address directly, we cannot discriminate between the above mentioned possibilities.

Since endogenous CaMKII $\delta_{\mathrm{C}}$ associates with the $\mathrm{Na}^{+}$channels, it was tested whether endogenous CaMKII can phosphorylate $\mathrm{Na}^{+}$channels in the myocytes (Fig. 10C). Saponin-permeabilized rabbit myocytes were exposed for 5 minutes to internal solution at $50 \mathrm{nM} \mathrm{Ca}^{2+}$ or $500 \mathrm{nM} \mathrm{Ca}^{2+}$ plus $2 \mu \mathrm{M} \mathrm{CaM}$ (to activate endogenous CaMKII). The extent of CaMKII-dependent $\mathrm{Na}^{+}$channel phosphorylation was assessed afterwards by $\mathrm{Na}^{+}$ channel immunoprecipitation and subsequent back-phosphorylation with exogenous preactivated CaMKII and $\left[\gamma^{32} \mathrm{P}\right]$-ATP. Activation of endogenous CaMKII $\left(500 \mathrm{nM} \mathrm{Ca}^{2+}\right)$ reduced back-phosphorylation (Fig. 10C lane 2 versus lane 1), indicating increased $\mathrm{Na}^{+}$ channel phosphorylation upon activation of cellular CaMKII. Inclusion of AIP during preincubation of the myocyte prevented the increased phosphorylation (Fig. 10C lane 3). Interestingly, overexpression of $\mathrm{CaMKII} \delta_{\mathrm{C}}$ increased the phosphorylation level (decreased back-phosphorylation) of $\mathrm{Na}^{+}$channels at $50 \mathrm{nM} \mathrm{Ca}^{2+}$ to a level comparable to that attained in the control at the $500 \mathrm{nM} \mathrm{Ca}^{2+}$ incubation. Thus, CaMKII associates with the $\mathrm{Na}^{+}$channel and endogenous CaMKII can phosphorylate the $\mathrm{Na}^{+}$channel.

\subsubsection{Protein expression level of $\mathrm{Na}^{+}$channels}

To test whether $\mathrm{Na}^{+}$channel protein expression levels were changed, Western blot analysis was performed. Protein homogenates prepared from WT and CaMKII $\delta_{\mathrm{C}}$ transgenic mouse hearts as well as protein lysates from rabbit cardiomyocytes prepared 24 hours after transfection with CaMKII $\delta_{\mathrm{C}}$ at MOI 100 (or not transfected as control) were denatured in sample buffer containing $2 \% \beta$-mercaptoethanol by warming at $37^{\circ} \mathrm{C}$ for 30 minutes and $50 \mu \mathrm{g}$ and $25 \mu \mathrm{g}$, respectively, of total protein was subjected to SDS-polyacrylamide gel. Western blotting performed with the antibody against $\mathrm{Na}^{+}$channels (anti-Pan $\mathrm{Na}_{\mathrm{v}}$, Alomone Labs) revealed a significantly elevated (1.6-fold) $\mathrm{Na}^{+}$channel expression level in hearts from CaMKII $\delta_{\mathrm{C}}$ TG as compared to that of WT mice (Fig. 11A). In contrast, $\mathrm{Na}^{+}$ 
channel expression levels were not altered in rabbit cardiomyocytes acutely overexpressing CaMKII $\delta_{\mathrm{C}}$ for 24 hours (Fig. 11B). For quantification, the $\mathrm{Na}^{+}$channel level was normalized to calsequestrin protein expression.

A

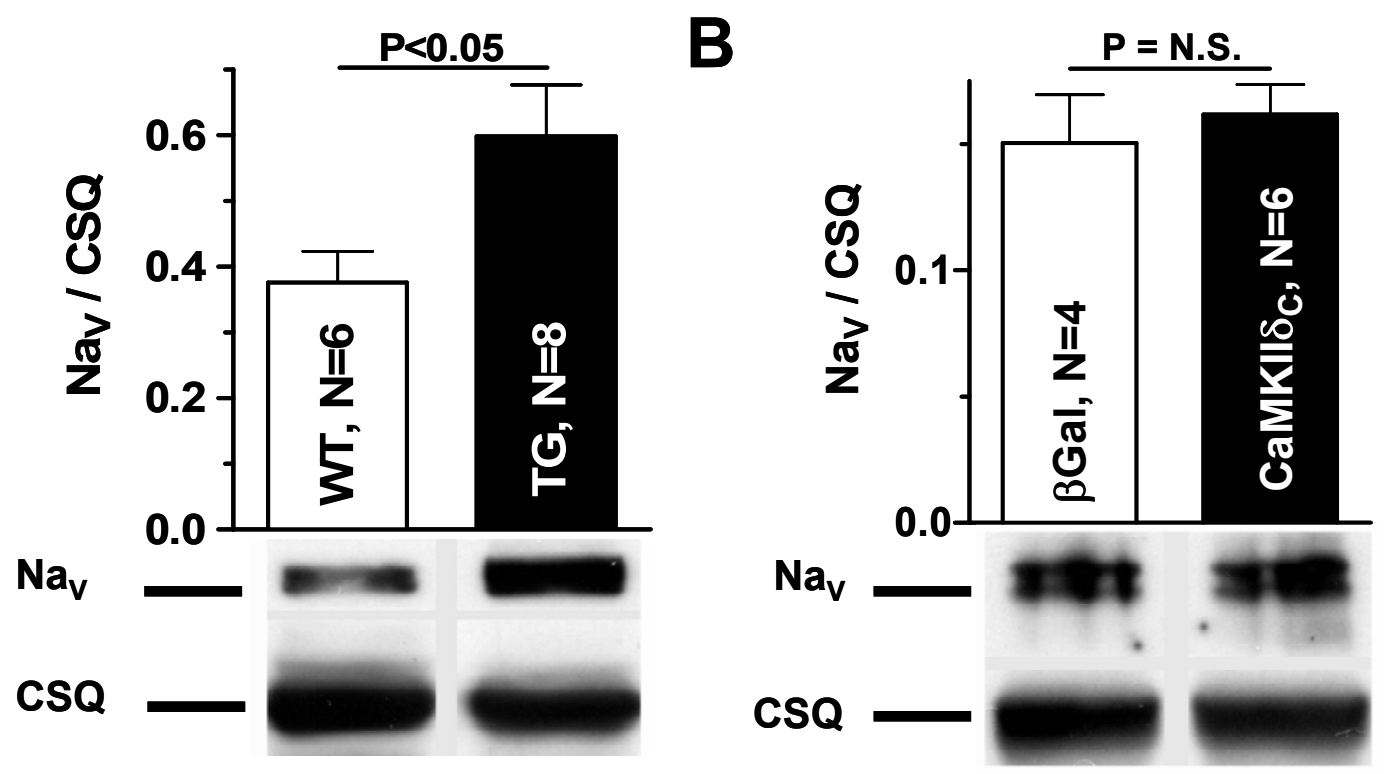

Figure 11. Protein expression levels of $\mathrm{Na}^{+}$channel in mice $\left(\right.$CaMKIII $\delta_{\mathrm{C}}$ TG versus WT) and in transfected rabbit myocytes (CaMKII $\delta_{C}$ versus $\beta$-gal, MOI of 100, 24 hours). Cardiac homogenates from (A) WT and CaMKII $\delta_{\mathrm{C}} \mathrm{TG}$ mice as well as (B) total lysates from $\beta$-gal and CaMKII $\delta_{\mathrm{C}}$ transfected rabbit cardiomyocytes were separated on $7.5 \%$ polyacrylamide-SDS gels and transferred to nitrocellulose. Western blots were developed with anti- $\mathrm{Pan} \mathrm{Na}_{\mathrm{v}}$ antibody (upper panel) and anti-calsequestrin (CSQ) antibody (bottom panel). The amount of the proteins was determined densitometrically. 


\subsection{Generation and identification of mutant mice}

\subsubsection{PCR-mediated verification of genotypes of mutant mice}

CaMKII $\delta_{\mathrm{C}}$ transgenic mice exhibiting a 3-fold increase in CaMKII activity were provided by Dr. Tong Zhang and Dr. Joan Heller Brown (Zhang et. al., 2003). Knock-in mice harboring the R4496C mutation (RyR2 $2^{\mathrm{R} 4496 \mathrm{C}+/}$ ) were kindly provided by Dr. Silvia G. Priori (Cerrone et al., 2005). CaMKII $\delta_{\mathrm{C}} / \mathrm{RyR} 2^{\mathrm{R} 4496 \mathrm{C}}$ double mutant mice were generated by crossbreeding of RyR2 ${ }^{\mathrm{R} 4496 \mathrm{C}+/}$ mice with $\mathrm{CaMKII} \delta_{\mathrm{C}}$ mice. Mice were born to the expected

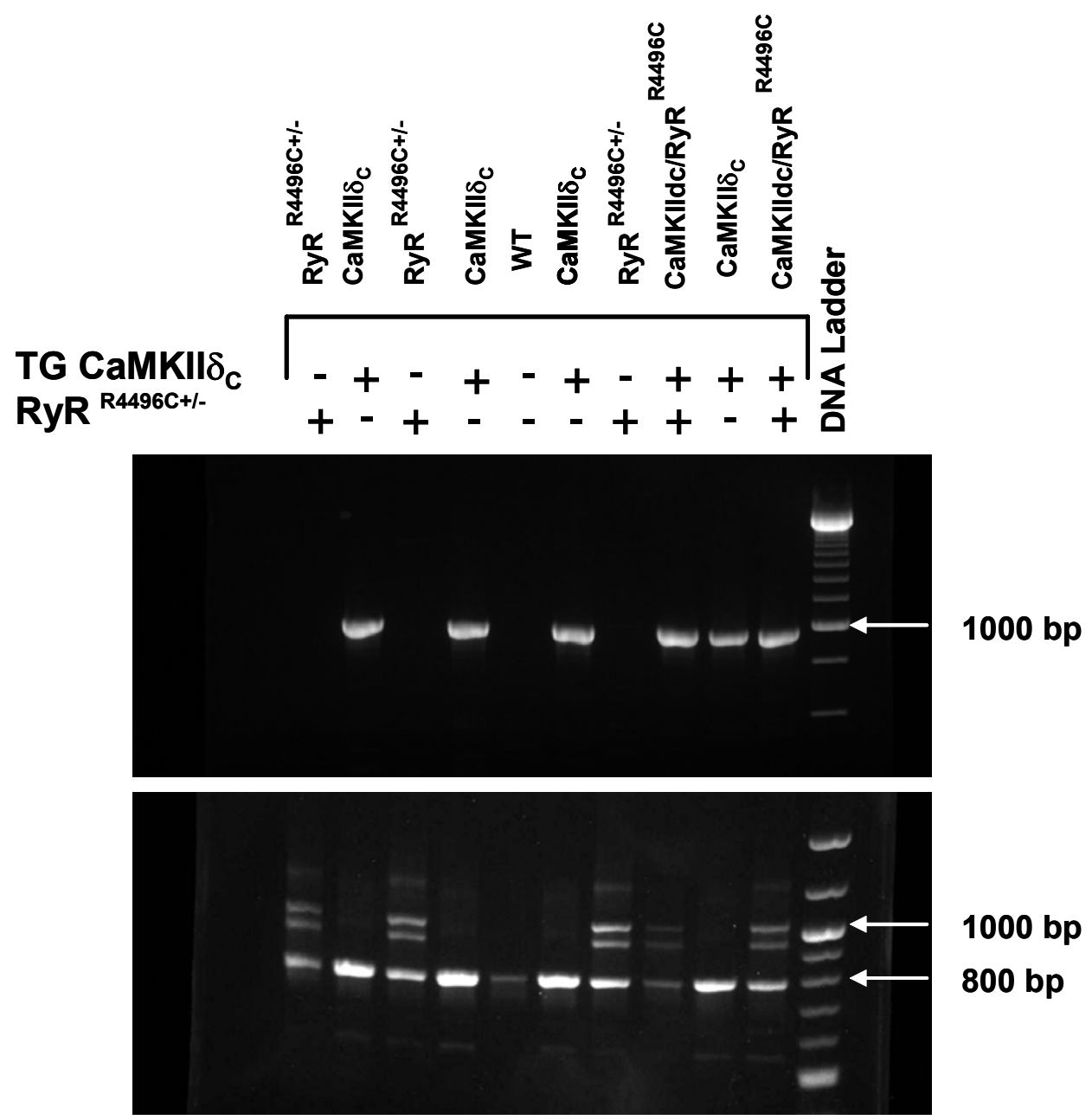

Figure 12. PCR confirmation of CaMKII $\delta_{C}$ TG, RyR2 ${ }^{\text {R4496C+/- }}$ knock-in and WT mouse genotypes. The 1000-bp bands on the upper gel indicate the CaMKII $\delta_{\mathrm{C}} \mathrm{TG}$ and no bands show WT mice. The $800-\mathrm{bp}$ and $1000-\mathrm{bp}$ bands on the bottom gel indicate the heterozygous RyR2 ${ }^{\mathrm{R} 4496 \mathrm{C}+/}$ and the 800-bp point to WT mice. The CaMKII $\delta_{C} / \mathrm{RyR}^{\mathrm{R} 4496 \mathrm{C}}$ were double heterozygous mice that have both the CaMKII $\delta_{\mathrm{C}}$ transgene and the RyR2 ${ }^{\mathrm{R} 4496 \mathrm{C}}$ mutation. 
mendelian ratios. CaMKII $\delta_{\mathrm{C}}, \mathrm{RyR}^{\mathrm{R} 4496 \mathrm{C}+/-}, \mathrm{CaMKII} \delta_{\mathrm{C}} / \mathrm{RyR} 2^{\mathrm{R} 4496 \mathrm{C}}$ mice and respective WT controls, 8-14 weeks old, of either sex were used.

PCR using DNA from ear biopsy was performed as described in the Methods (3.1) with CaMKII $\delta_{C^{-}}$and RyR2-specific primers to determine the genotype of the mutant mice (Fig.12). CaMKII $\delta_{\mathrm{C}}$ transgenic mice displayed a band on the $2 \%$ agarose gel at $1000-\mathrm{bp}$, whereas WT mice showed no band. RyR2 ${ }^{\mathrm{R} 4496 \mathrm{C}+/}$ heterozygous mice display 2 bands on the $1 \%$ agarose gel at $800-\mathrm{bp}$ and $1000-\mathrm{bp}$, while WT have 1 band of $800-\mathrm{bp}$. The generation of CaMKII $\delta_{\mathrm{C}} / \mathrm{RyR} 2^{\mathrm{R} 4496 \mathrm{C}}$ double mutant mice was confirmed by the presence of the PCR products characteristic for $\mathrm{CaMKII} \delta_{\mathrm{C}}$ transgene and RyR2 gene harboring the R4496C mutation.

\subsubsection{Cardiac overexpression of CaMKII $\delta_{C}$ in CaMKII $\delta_{C}$ TG and RyR2 $2^{R 496 C+/-}$ mice induces cardiac hypertrophy and mortality}

No difference between WT versus RyR2 $2^{\mathrm{R} 4496 \mathrm{C}+/}$ mice was present in the duration of the pregnancy, development, size, weight, survival and behavior. Whereas CaMKII $\delta_{\mathrm{C}}$ overexpression alone as well as crossbreeding of RyR2 ${ }^{\mathrm{R} 4496 \mathrm{C}+/}$ knock-in mutant with CaMKIII $\delta_{C}$ transgenic mice induced hypertrophy, ventricular dilation and increased mortality. There was a significant enlargement of hearts and single myocytes from CaMKII $\delta_{\mathrm{C}} / \mathrm{RyR}^{\mathrm{R} 4496 \mathrm{C}}$ double mutant and CaMKII $\delta_{\mathrm{C}}$ transgenic mice by age of 8 to 14 weeks. However, the hearts and single myocytes of RyR2 $2^{\mathrm{R} 4496 \mathrm{C}+/}$ mice did not show any abnormalities (Fig. 13A). After cardiectomy, when the heart was carefully separated from other tissues the heart as well as body weight was assessed. Heart weight/body weight ratio in $\mathrm{CaMKII} \delta_{\mathrm{C}} / \mathrm{RyR}^{\mathrm{R} 4496 \mathrm{C}}$ double mutant $(19.57 \pm 0.72 \mathrm{mg} / \mathrm{g} ; \mathrm{n}=34)$ and $\mathrm{CaMKII} \delta_{\mathrm{C}}$ transgenic $(20.78 \pm 1.25 \mathrm{mg} / \mathrm{g} ; \mathrm{n}=29)$ mice was significantly increased about 3-fold versus RyR2 $^{\text {R4496C+/- }}(7.33 \pm 0.23 \mathrm{mg} / \mathrm{g} ; \mathrm{n}=25 ; \mathrm{P}<0.05)$ and WT mice $(7.17 \pm 0.15 \mathrm{mg} / \mathrm{g} ; \mathrm{n}=29$; $\mathrm{P}<0.05$ ) (Fig. 13B). In all cases the increase in ventricular mass is paralleled by myocyte hypertrophy (Bers, 2001). Quantitative analysis of cardiomyocyte cell volume from 12week-old mice gave values of $42.57 \pm 1.95 \mathrm{pl}$ for $\mathrm{CaMKII} \delta_{\mathrm{C}} / \mathrm{RyR}^{\mathrm{R} 4496 \mathrm{C}}(\mathrm{n}=76), 36.71 \pm 1.76$ $\mathrm{pl}$ for $\mathrm{CaMKII}_{\mathrm{C}}(\mathrm{n}=110)$ versus $21.02 \pm 1.15 \mathrm{pl}$ for $\mathrm{RyR}^{\mathrm{R} 4496 \mathrm{C}+-}(\mathrm{n}=88 ; \mathrm{P}<0.05)$ and $23.00 \pm 1.26 \mathrm{pl}$ for WT $(\mathrm{n}=91 ; \mathrm{P}<0.05)$. The myocytes were enlarged (as judged length/width ratio) in CaMKII $\delta_{\mathrm{C}} / \mathrm{RyR}^{\mathrm{R} 4496 \mathrm{C}}(8.34 \pm 0.26 ; \mathrm{n}=76)$ and $\mathrm{CaMKII}_{\mathrm{C}}(8.15 \pm 0.19$; $\mathrm{n}=110)$ mice versus RyR2 ${ }^{\mathrm{R} 4496 \mathrm{C}+/}(5.25 \pm 0.09 ; \mathrm{n}=88 ; \mathrm{P}<0.05)$ and WT $(5.33 \pm 0.12 ; \mathrm{n}=90$; $\mathrm{P}<0.05)$ (Fig. 13A). 

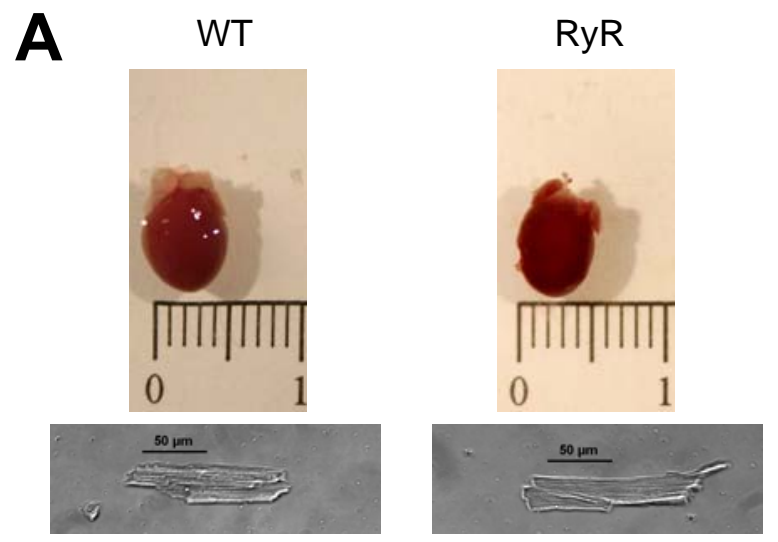

RyR/CaMKII

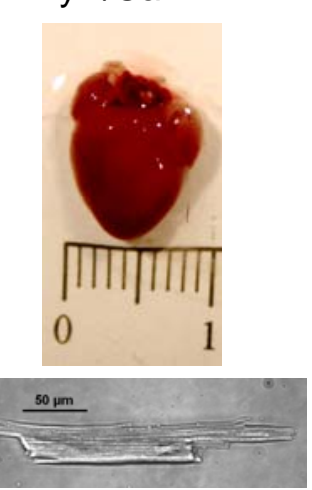

CaMKII
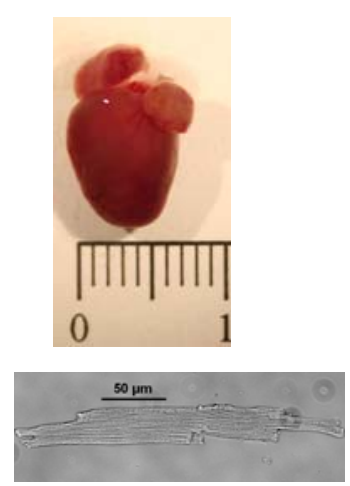

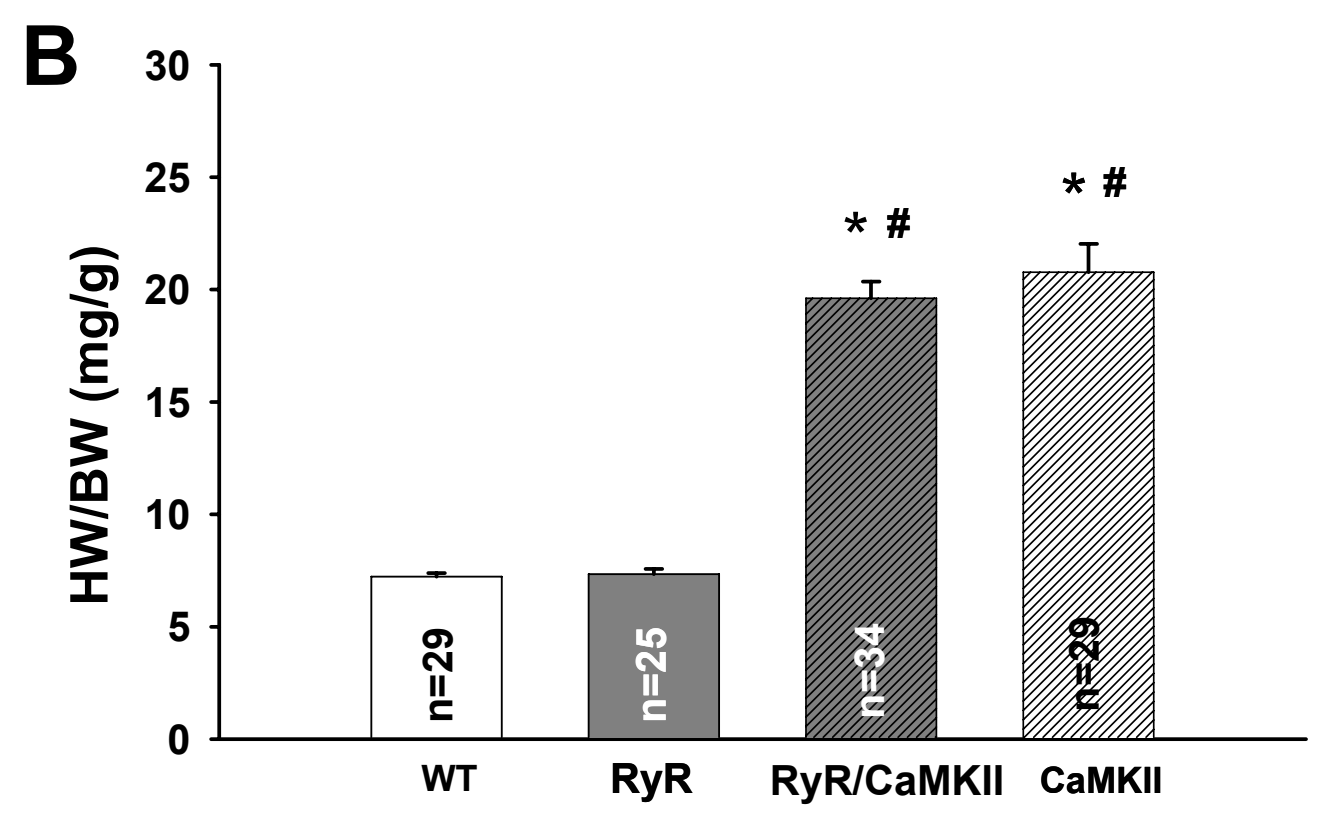

Figure 13. CaMKII $\delta_{\mathrm{C}}$ overexpression in mouse hearts induced cardiac hypotrophy. (A) Representative images of whole hearts and ventricular myocytes isolated from WT, RyR2 $2^{\mathrm{R} 4496 \mathrm{C}+/}$, CaMKII $\delta_{\mathrm{C}} / \mathrm{RyR}^{\mathrm{R} 4496 \mathrm{C}}$ and CaMKIII $\delta_{\mathrm{C}}$ mice at 13 weeks of age showing heart hypertrophy in CaMKII $\delta_{\mathrm{C}} / \mathrm{RyR}^{\mathrm{R} 4496 \mathrm{C}}$ and CaMKIII $\delta_{\mathrm{C}}$ mice. (B) Average ratios of heart weight/body weight in WT, RyR2 ${ }^{\mathrm{R} 4496 \mathrm{C}+/}, \mathrm{CaMKII}_{\mathrm{C}} / \mathrm{RyR}^{\mathrm{R} 4496 \mathrm{C}}$ and CaMKII $\delta_{\mathrm{C}}$ mice. ${ }^{*} \mathrm{P}<0.05$ versus WT. \# $\mathrm{P}<0.05$ versus RyR2 ${ }^{\mathrm{R} 4496 \mathrm{C}+/}$. 
Interestingly, while RyR2 ${ }^{\mathrm{R} 4496 \mathrm{C}+/}$ knock-in mice had a normal life span and CaMKII $\delta_{\mathrm{C}}$ transgenic mice, had a premature mortality rate of only $20 \%$ until 10 weeks, CaMKII $\delta_{C} /$ RyR $^{\text {R4496C }}$ double mutant died spontaneously with only $50 \%$ survival after 10 weeks ( $\mathrm{P}<0.05$ versus RyR2 ${ }^{\mathrm{R} 4496 \mathrm{C}+/}$, CaMKII $\delta_{\mathrm{C}}$, and WT; Fig. 14).

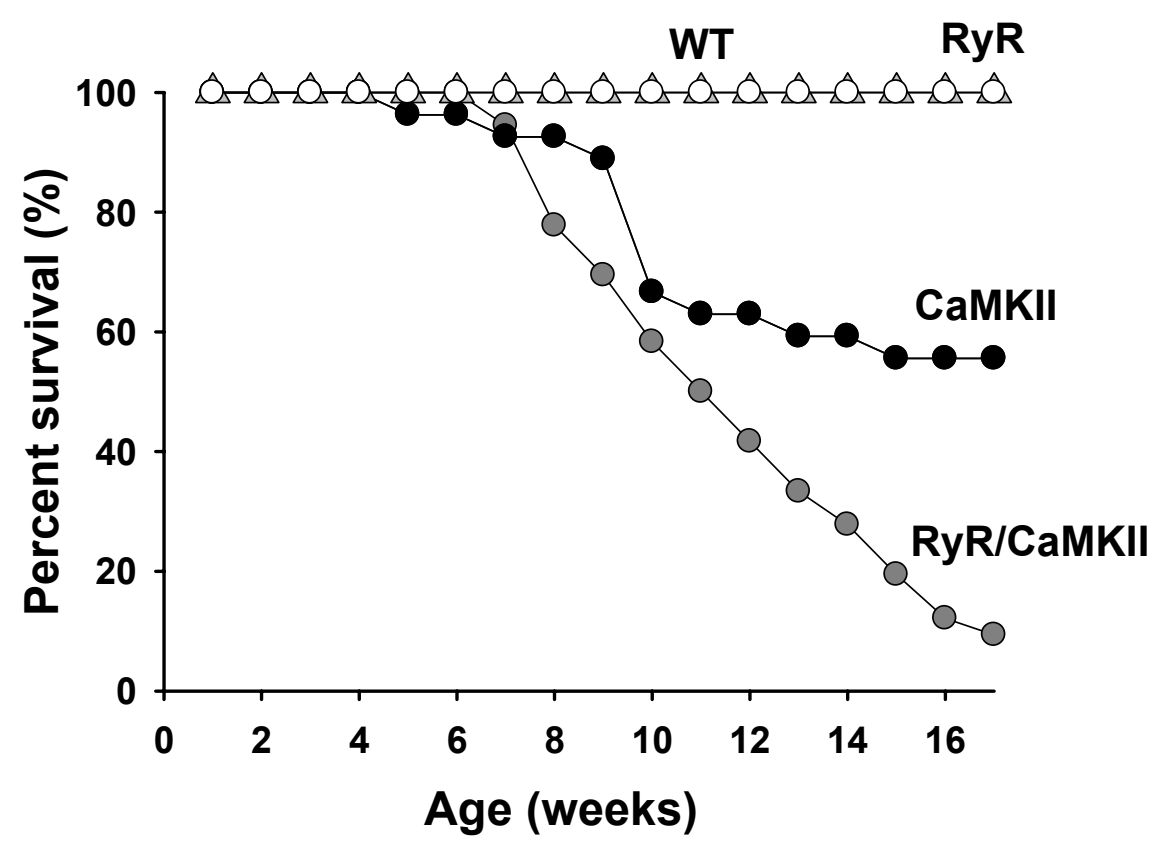

Figure 14. Overexpression of CaMKII $\delta_{C}$ led to sudden premature death. Survival curve for WT (n=37), RyR2 ${ }^{\mathrm{R} 4496 \mathrm{C}+-}(\mathrm{n}=28), \mathrm{CaMKII}_{\mathrm{C}} / \mathrm{RyR}^{\mathrm{R} 4496 \mathrm{C}}(\mathrm{n}=35)$ and CaMKII $\delta_{\mathrm{C}}(\mathrm{n}=22)$ mice with significantly impaired survival for CaMKII $\delta_{\mathrm{C}} / \mathrm{RyR} 2^{\mathrm{R} 4496 \mathrm{C}}$ double mutant mice as compared to the $\mathrm{RyR}^{\mathrm{R} 4496 \mathrm{C}+/}$ knock-in mutant, CaMKII $\delta_{\mathrm{C}}$ transgenic, and WT mice.

\subsection{Echocardiographic analysis of $\mathrm{RyR2}^{\mathrm{R4496}+/-}, \mathrm{CaMKII} \delta_{\mathrm{C}} / \mathrm{RyR2}^{\mathrm{R} 4496 \mathrm{C}}$, CaMKIII $\delta_{C}$ and WT mice}

To analyze the consequences of the R4496C knock-in mutation in vivo, M-mode echocardiography of RyR2 $2^{\mathrm{R} 4496 \mathrm{C}+/}$, CaMKII $\delta_{\mathrm{C}} / \mathrm{RyR} 2^{\mathrm{R} 4496 \mathrm{C}}, \mathrm{CaMKII} \delta_{\mathrm{C}}$ and WT mice was performed as described in the Methods (3.11). The hearts of RyR2 ${ }^{\mathrm{R} 4496 \mathrm{C}+/-}$ knock-in mice showed normal dimensions as well as contractile function in the echocardiographic measurements. In stark contrast, CaMKII $\delta_{\mathrm{C}} / \mathrm{RyR}^{\mathrm{R} 4496 \mathrm{C}}$ double mutant and CaMKII $\delta_{\mathrm{C}}$ transgenic mice exhibited evident cardiac remodeling and systolic dysfunction (Fig. 15). Left ventricular end diastolic diameter (LVEDD; Fig. 16A) in CaMKII $\delta_{\mathrm{C}} / \mathrm{RyR}^{\mathrm{R} 4496 \mathrm{C}}$ 
$(5.45 \pm 0.4 \mathrm{~mm} ; \mathrm{n}=6)$ and $\mathrm{CaMKIII} \delta_{\mathrm{C}}(5.77 \pm 0.7 \mathrm{~mm} ; \mathrm{n}=5)$ mice was significantly increased as compared to RyR2 $2^{\mathrm{R} 4496 \mathrm{C}+/}(3.55 \pm 0.2 \mathrm{~mm} ; \mathrm{n}=5 ; \mathrm{P}<0.05)$ or WT $(3.02 \pm 0.3 \mathrm{~mm}$; $\mathrm{n}=6$; $\mathrm{P}<0.05)$.

\section{WT}

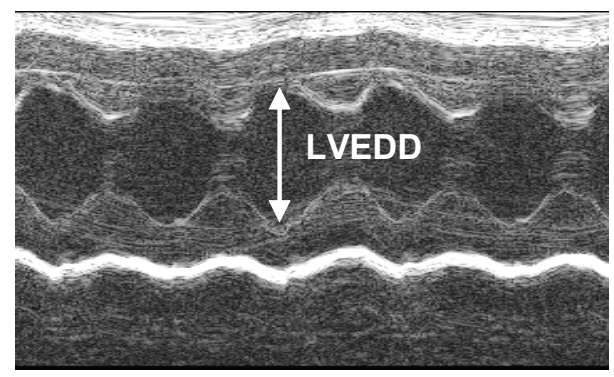

\section{RyR/CaMKII}

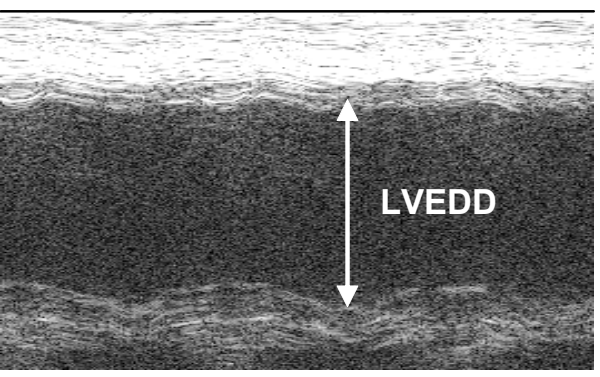

RyR

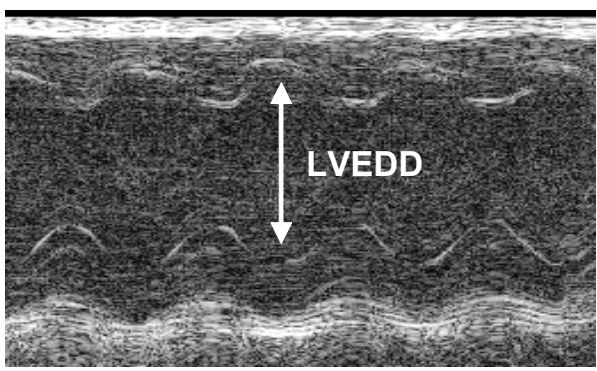

\section{CaMKII}

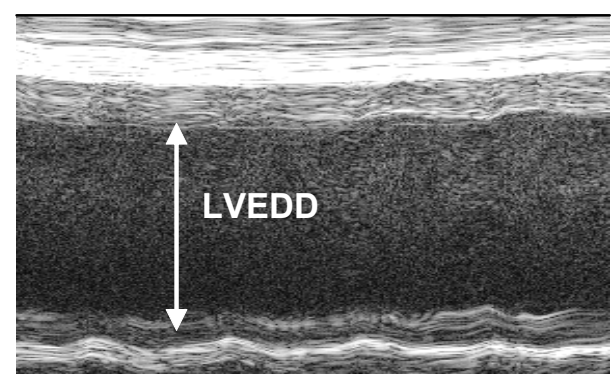

Figure 15. Dilated cardiomyopathy and cardiac dysfunction at the whole heart level in vivo in CaMKII $\delta_{\mathrm{C}} / \mathbf{R y R 2}^{\mathrm{R} 4496}$ and CaMKII $\boldsymbol{\delta}_{\mathrm{C}}$ mice. Representative M-mode images of echocardiography in WT, RyR2 ${ }^{\mathrm{R} 4496 \mathrm{C}+/}, \mathrm{CaMKII} \delta_{\mathrm{C}} / \mathrm{RyR} 2^{\mathrm{R} 4496 \mathrm{C}}$ and CaMKII $\delta_{\mathrm{C}}$ mice at $10-13$ weeks of age.

In parallel, left ventricular posterior wall thickness (LVPW; Fig. 16B) decreased significantly in both $\mathrm{CaMKII}_{\mathrm{C}} / \mathrm{RyR}^{\mathrm{R} 4496 \mathrm{C}}$ double mutant $(0.59 \pm 0.03 \mathrm{~mm} ; \mathrm{n}=6)$ and CaMKII $\delta_{C}$ transgenic mice $(0.52 \pm 0.04 \mathrm{~mm} ; \mathrm{n}=5)$ versus RyR2 $2^{\mathrm{R} 4496 \mathrm{C}+/-}(0.77 \pm 0.06 \mathrm{~mm}$; $\mathrm{n}=5 ; \mathrm{P}<0.05)$ and WT $(0.96 \pm 0.06 \mathrm{~mm} ; \mathrm{n}=6 ; \mathrm{P}<0.05)$. 
A
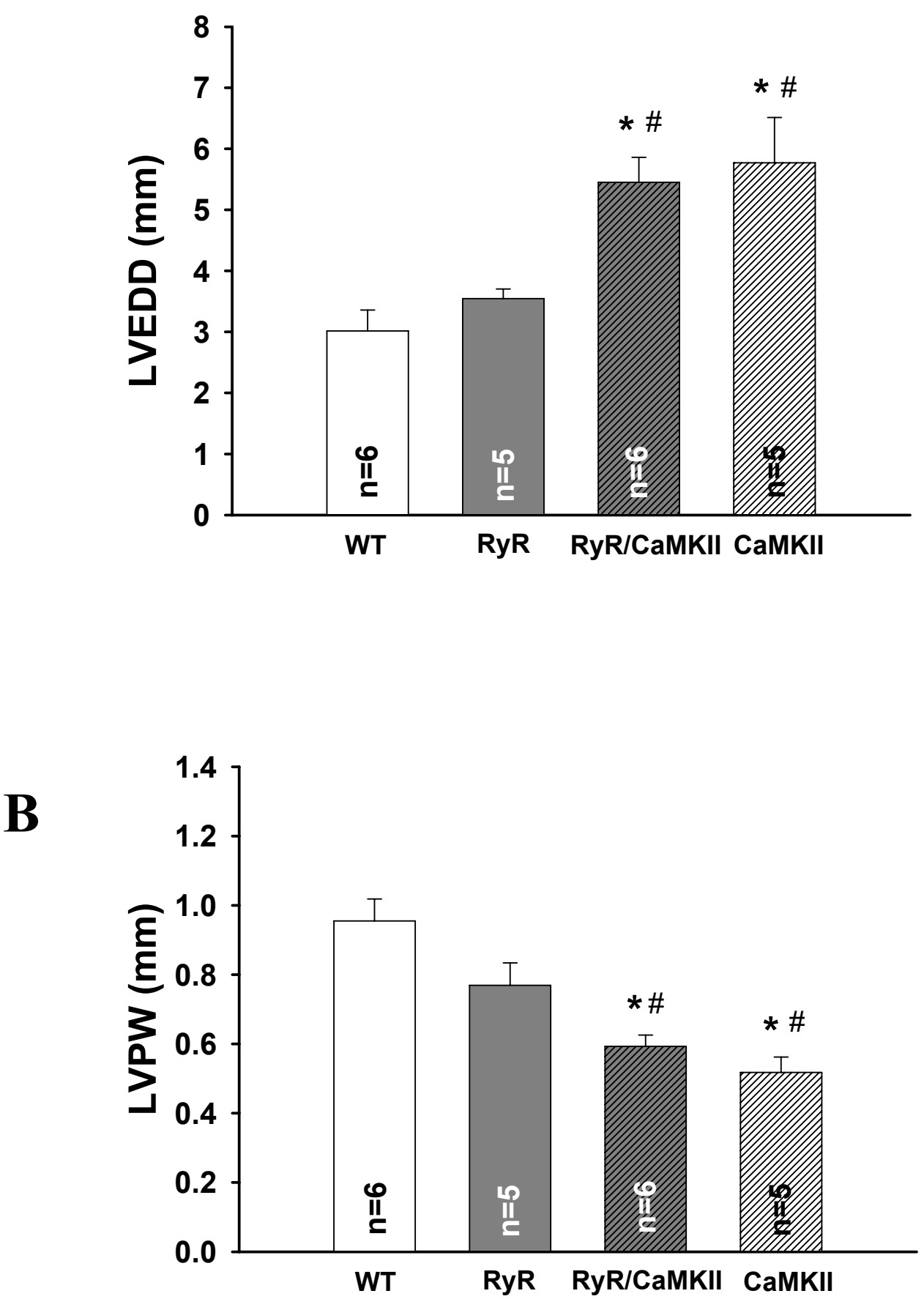

Figure 16. Averaged structural echocardiographic parameters for WT, RyR2 ${ }^{\mathrm{R} 4496 \mathrm{C}+/}$, CaMKIII $\delta_{C} /$ RyR2 $^{\text {R4496C }}$ and CaMKII $\delta_{C}$ mice. Data are presented for left ventricular end diastolic diameter (LVEDD) and left ventricular posterior wall thickness (LVPW). Ventricular dilation and wall thinning in $\mathrm{CaMKII} \delta_{\mathrm{C}} / \mathrm{RyR}^{\mathrm{R} 4496 \mathrm{C}}$ and $\mathrm{CaMKII} \delta_{\mathrm{C}}$ mice can be seen. ${ }^{*} \mathrm{P}<0.05$ versus WT. \# $\mathrm{P}<0.05$ versus $\mathrm{RyR} 2^{\mathrm{R} 4496 \mathrm{C}+/}$. 


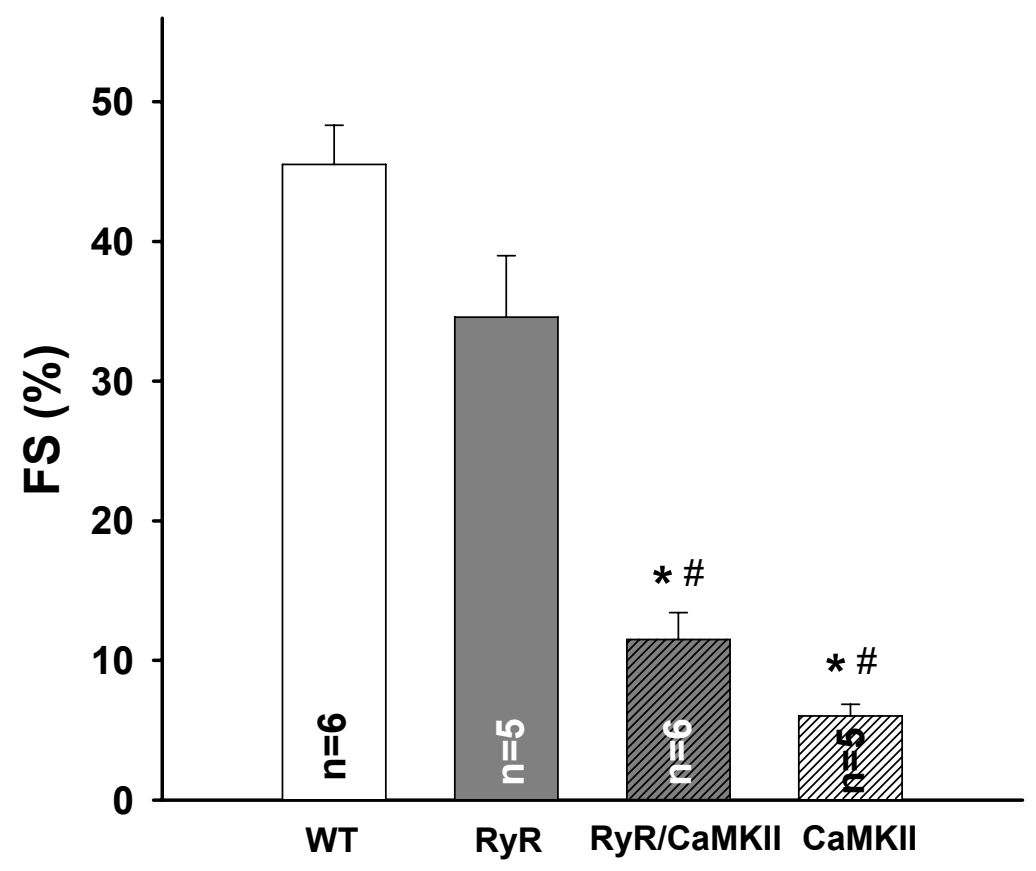

Figure 17. Averaged functional echocardiographic parameter for WT, RyR2 ${ }^{\mathrm{R} 4496 \mathrm{C}+/}$, CaMKIII $_{\mathrm{C}} / \mathbf{R y R 2}^{\mathrm{R} 4496 \mathrm{C}}$ and CaMKII $\boldsymbol{\delta}_{\mathrm{C}}$ mice. Data are presented for fractional shortening (FS). Percentage of fractional shortening calculated as 100×((LVEDD-LVESD)/LVEDD). LVEDD indicates left ventricular end diastolic diameter; LVESD indicates left ventricular end systolic diameter. Impaired fractional shortening indicated contractile dysfunction pointing to heart failure in $\mathrm{CaMKII} \delta_{\mathrm{C}} / \mathrm{RyR}^{\mathrm{R} 4496 \mathrm{C}}$ and CaMKII $\delta_{\mathrm{C}}$ mice. ${ }^{*} \mathrm{P}<0.05$ versus WT. \# $\mathrm{P}<0.05$ versus RyR2 $2^{\mathrm{R} 4496 \mathrm{C}+/}$.

Most importantly, fractional shortening was dramatically reduced in CaMKII $\delta_{\mathrm{C}} / \mathrm{RyR}^{\mathrm{R} 4496 \mathrm{C}}(11.50 \pm 1.9 \% ; \mathrm{n}=6)$ and $\mathrm{CaMKII} \delta_{\mathrm{C}}(5.85 \pm 1 \% ; \mathrm{n}=5)$ in contrast to RyR2 $^{\text {R4496C+/- }}(34.58 \pm 4.4 \% ; \mathrm{n}=5 ; \mathrm{P}<0.05)$ and WT $(45.52 \pm 2.8 \% ; \mathrm{n}=6 ; \mathrm{P}<0.05 ;$ Fig. 17). Alteration of these parameters indicates development of contractile dysfunction in a heart failure phenotype in CaMKII $\delta_{\mathrm{C}} / \mathrm{RyR}^{\mathrm{R} 4496 \mathrm{C}}$ double mutant very similar to CaMKII $\delta_{\mathrm{C}}$ transgenic mice. It should be noted that none of these parameters was significantly altered in $\mathrm{RyR} 2^{\mathrm{R} 4496 \mathrm{C}+/}$ knock-in mice as compared to WT. 


\subsection{Analysis of cardiomyocyte shortening and $\mathrm{Ca}^{2+}$ transients using an epifluorescence microscope}

\subsubsection{Fractional shortening and intracellular $\mathrm{Ca}^{2+}$ transients}

The functional effect of the RyR2 ${ }^{\mathrm{R} 4496 \mathrm{C}+/}$ knock-in mutation and CaMKII $\delta_{\mathrm{C}} / \mathrm{RyR}^{\mathrm{R} 4496 \mathrm{C}}$ cross-bred models as well as CaMKII $\delta_{\mathrm{C}}$ transgenic overexpression, was probed by measuring intracellular $\mathrm{Ca}^{2+}$ transients in vitro using a $\mathrm{Ca}^{2+}$-fluorescent dye in Fluo-3loaded isolated ventricular myocytes. Fractional shortening was simultaneously assessed. Isolation of mouse ventricular myocytes was performed using enzymatic digestion as described in the Methods (3.8). The images of the myocytes were recorded using a camera (MyoCam) and displayed on a monitor. The fluorescent dye was excited by a $75 \mathrm{~W}$ xenon arc lamp at $480 \pm 15 \mathrm{~nm}$ on the stage of a Nikon Eclipse TE200-U inverted microscope as described in the Methods (3.9). Myocytes were field-stimulated at $1 \mathrm{~Hz}$ and $37^{\circ} \mathrm{C}$ until steady-state was achieved and shortening was measured using a sarcomere length detection system. After steady-state conditions were achieved, stimulation frequency was increased stepwise from $1 \mathrm{~Hz}$ to 2,4 and $8 \mathrm{~Hz}$. The cells selected for data analysis had clear striation, rod-shaped form and stable diastolic length.

In cardiac muscle, $\mathrm{Ca}^{2+}$ directly contributes to electrical and contractile activity and is central to E-C coupling (Bers, 2001; Bers, 2002). Alterations in intracellular $\mathrm{Ca}^{2+}$ could also result in hypertrophy and heart failure. The amplitude of the $\mathrm{Ca}^{2+}$ transient is generated mainly by $\mathrm{SR} \mathrm{Ca}^{2+}$ release in the murine heart and directly determines the extent of contractile force in cardiomyocytes. As shown by the original traces in Figures 18\&19, both twitch $\mathrm{Ca}^{2+}$ transient amplitude and shortening were significantly decreased in CaMKIII $\delta_{C} / \mathrm{RyR}^{\mathrm{R} 4496 \mathrm{C}}$ and CaMKII $\delta_{\mathrm{C}}$ as compared to RyR2 ${ }^{\mathrm{R} 4496 \mathrm{C}+/}$ and WT myocytes. Average data (Fig. 20) show that $\mathrm{Ca}^{2+}$ transient amplitudes were only $215.27 \pm 7.73 \mathrm{nM}$ in $\mathrm{CaMKII}_{\mathrm{C}} / \mathrm{RyR}^{\mathrm{R} 4496 \mathrm{C}}(\mathrm{n}=46)$ and $194.54 \pm 9.25 \mathrm{nM}$ in CaMKII $\delta_{\mathrm{C}}(\mathrm{n}=36)$ compared to $\mathrm{RyR}^{\mathrm{R} 4496 \mathrm{C}+/}$ with $435.58 \pm 20.16 \mathrm{nM}(\mathrm{n}=51 ; \mathrm{P}<0.05)$ and WT with $466.68 \pm 23.65 \mathrm{nM}$ $(\mathrm{n}=61 ; \mathrm{P}<0.05)$ at a baseline frequency of $1 \mathrm{~Hz}$. Accordingly, fractional shortening of isolated cardiomyocytes at $1 \mathrm{~Hz}$ was also significantly impaired in CaMKII $\delta_{\mathrm{C}} / \mathrm{RyR}^{\mathrm{R} 4496 \mathrm{C}}$ (3.32 $\pm 0.19 \%$ resting cell length; $n=46)$ and $\mathrm{CaMKII}_{\mathrm{C}}(3.34 \pm 0.24 \%$ resting cell length; $\mathrm{n}=36)$ mice versus $\mathrm{RyR} 2^{\mathrm{R} 4496 \mathrm{C}+/}(3.92 \pm 0.21 \%$ resting cell length, $\mathrm{n}=51 ; \mathrm{P}<0.05)$ and $\mathrm{WT}$ $(4.42 \pm 0.23 \%$ resting cell length; $\mathrm{n}=61 ; \mathrm{P}<0.05)$. Reduction in twitch contraction in CaMKII $\delta_{C} / \mathrm{RyR}^{\mathrm{R} 4496 \mathrm{C}}$ and CaMKII $\delta_{\mathrm{C}}$ mice was expected, because this is seen in almost all heart failure models. 
WT

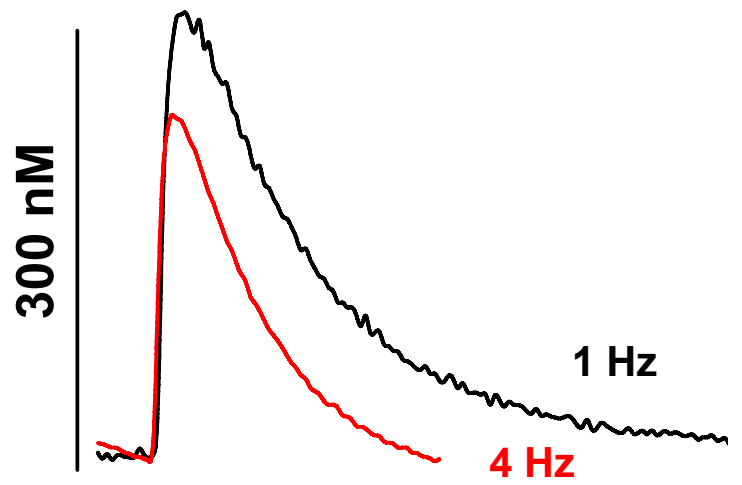

$400 \mathrm{~ms}$

\section{RyR/CaMKII}

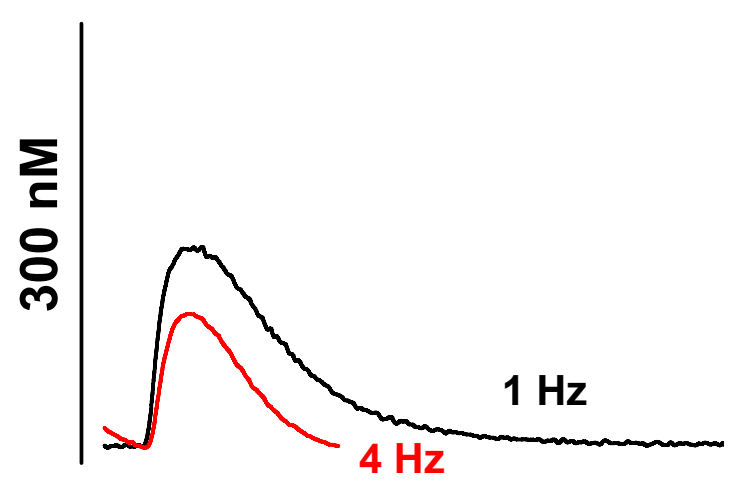

$400 \mathrm{~ms}$
RyR

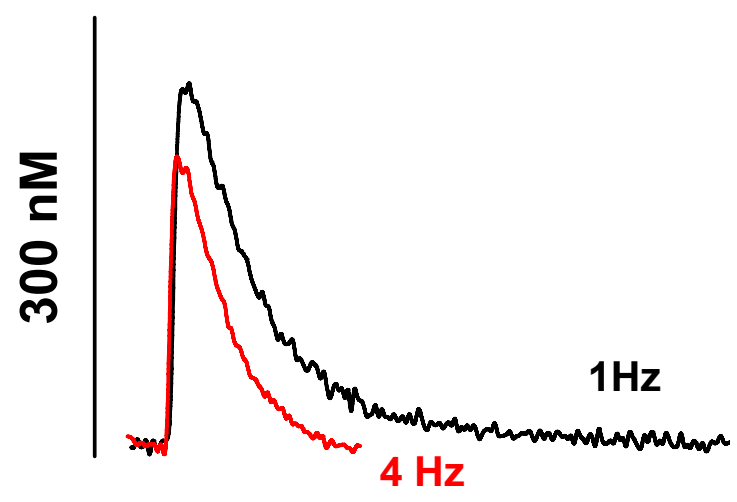

$400 \mathrm{~ms}$

\section{CaMKII}

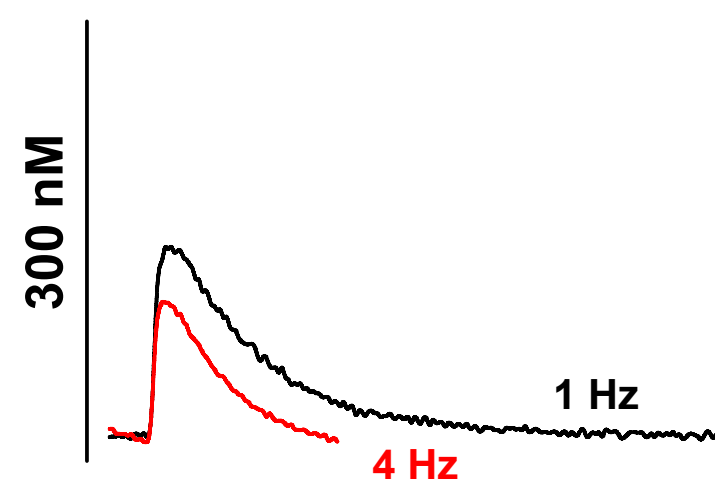

$400 \mathrm{~ms}$

Figure 18. Frequency-dependent changes in $\mathrm{Ca}^{2+}$ transient amplitude in isolated cardiomyocytes measured using Fluo-3. Original recordings for $\mathrm{Ca}^{2+}$ transient amplitude at 1 and $4 \mathrm{~Hz}$ showing a decrease in intracellular $\mathrm{Ca}^{2+}$ transients in CaMKII $\delta_{\mathrm{C}} / \mathrm{RyR}^{\mathrm{R} 4496 \mathrm{C}}$ and CaMKII $\delta_{\mathrm{C}}$ versus $\mathrm{RyR} 2^{\mathrm{R} 4496 \mathrm{C}+/}$ and WT. The graphs show the time-course of $\mathrm{Ca}^{2+}$ transients during a single systole-diastole cycle. 


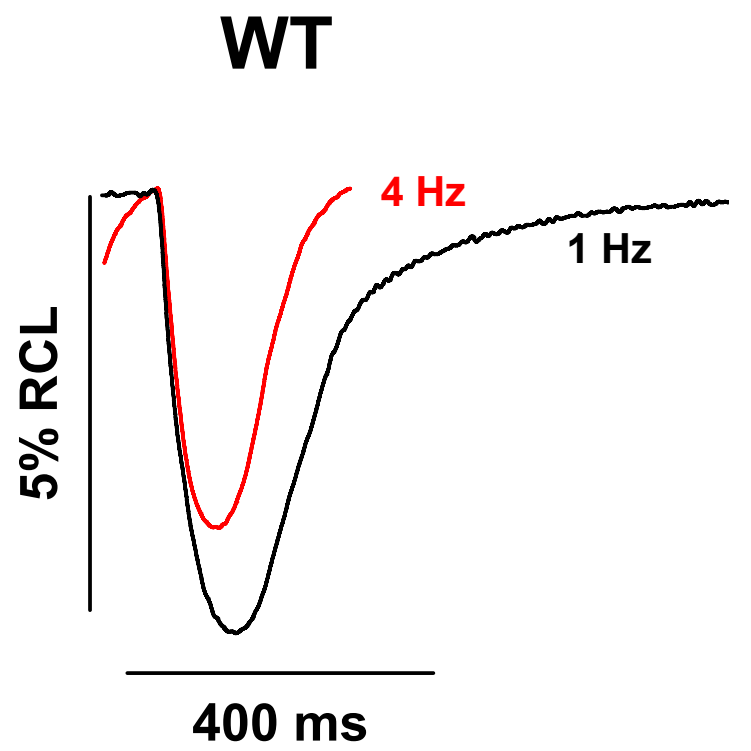

RyR

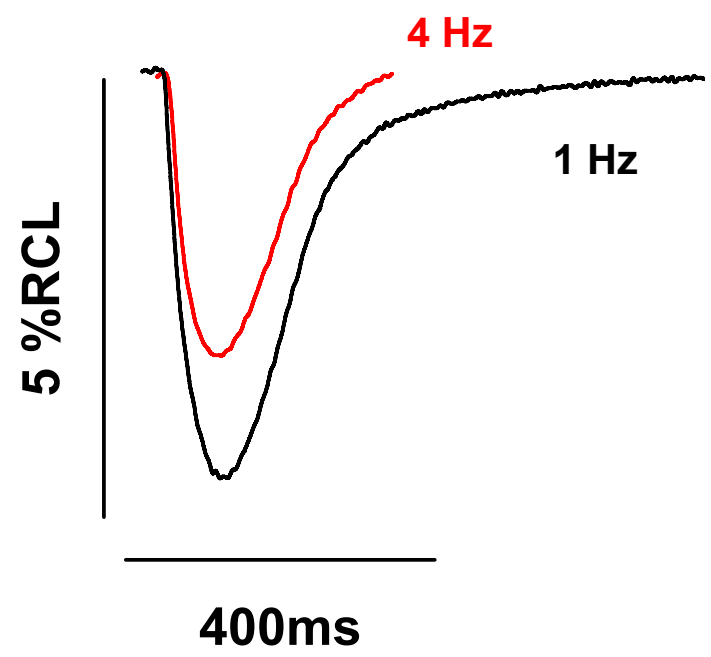

RyR/CaMKII

\section{CaMKII}
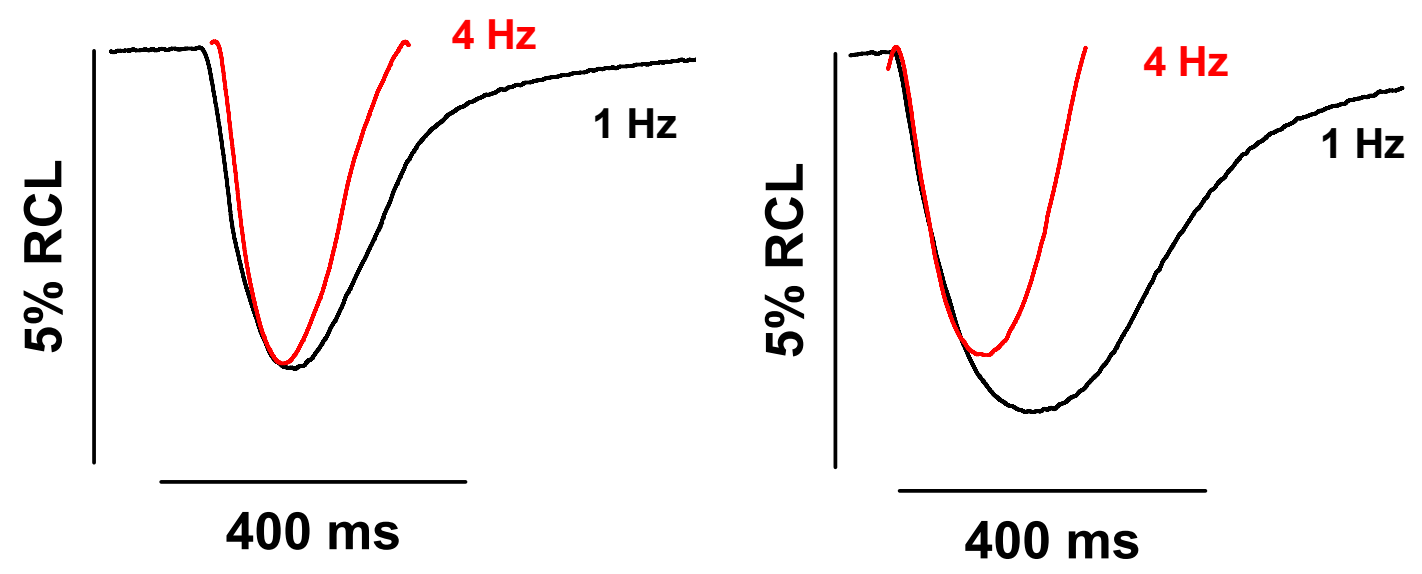

Figure 19. Frequency-dependent changes in fractional shortening in isolated cardiomyocytes measured using a sarcomere length detection system. Original recordings for twitch shortening (\% RCL $=\%$ resting cell length) at 1 and $4 \mathrm{~Hz}$ showing impaired fractional shortening in CaMKII $\delta_{\mathrm{C}} / \mathrm{RyR}^{\mathrm{R} 4496 \mathrm{C}}$ and $\mathrm{CaMKII} \delta_{\mathrm{C}}$ versus $\mathrm{RyR} 2^{\mathrm{R} 4496 \mathrm{C}+/}$ and WT. The graphs show the timecourse of cell length during a single systole-diastole cycle. 
In addition, while diastolic $\mathrm{Ca}^{2+}$ was only nonsignificantly increased in $\mathrm{RyR} 2^{\mathrm{R} 4496 \mathrm{C}+/-}$ $(162 \pm 23 \mathrm{nM} ; \mathrm{n}=24)$ versus WT $(138 \pm 16 \mathrm{nM} ; \mathrm{n}=24)$, it was dramatically reduced in CaMKII $\delta_{\mathrm{C}} / \mathrm{RyR}^{\mathrm{R} 4496 \mathrm{C}}(81 \pm 11 \mathrm{nM} ; \mathrm{n}=27)$ and $\mathrm{CaMKII}_{\mathrm{C}}(80 \pm 13 \mathrm{nM} ; \mathrm{n}=18)$ mice as compared to RyR2 $2^{\mathrm{R} 4496 \mathrm{C}+/}(\mathrm{P}<0.05)$ and WT $(\mathrm{P}<0.05)$.

\subsubsection{Frequency-dependence of shortening, intracellular $\mathrm{Ca}^{2+}$ transients and relaxation}

Increasing the stimulation frequency of cardiac muscle not only modifies the amplitude but also the relaxation kinetics of contractile force. A positive or negative force-frequency relationship (staircase) in cardiac muscle depends on the $\mathrm{Ca}^{2+}$ loading status of the SR and recovery of the RyR2 from inactivation. Mouse myocytes often show a negative forcefrequency relationship (Bers, 2001). To determine whether increased stimulation rates lead to changes in fractional shortening of myocytes (i.e. force-frequency relationship) and whether this may be due to altered intracellular $\mathrm{Ca}^{2+}$, cell shortening and $\mathrm{Ca}^{2+}$ transient amplitude at different stimulation frequencies were assessed. Increasing stimulation rates stepwise from $1 \mathrm{~Hz}$ to 2,4 and $8 \mathrm{~Hz}$ led to decreased intracellular $\mathrm{Ca}^{2+}$ transient amplitudes and fractional shortening in myocytes isolated from CaMKIII $\delta_{C} / R_{R R} 2^{R 4496 C}$ and CaMKII $\delta_{\mathrm{C}}$ mice as compared to $\mathrm{RyR} 2^{\mathrm{R} 4496 \mathrm{C}+/-}$ and WT with a negative staircase in all groups (Fig. 20). The time course of twitches and $\mathrm{Ca}^{2+}$ transients is critically dependent on $\mathrm{SR} \mathrm{Ca}^{2+}$ uptake and is physiologically accelerated at high stimulation rates (Bers, 2001). Figure 21 shows time courses of relaxation and $\mathrm{Ca}^{2+}$ decline during twitches at different stimulation frequencies. Half-relaxation time $\left(\mathrm{RT}_{50 \%}\right)$ for fractional shortening in cardiomyocytes stimulated at the baseline frequency of $1 \mathrm{~Hz}$ was significantly prolonged in CaMKII $\delta_{\mathrm{C}} / \mathrm{RyR}^{\mathrm{R} 4496 \mathrm{C}}\left(\mathrm{RT}_{50 \%}: 110 \pm 6 \mathrm{~ms} ; \mathrm{n}=46\right)$ and CaMKII $\delta_{\mathrm{C}}$ mice $\left(\mathrm{RT}_{50 \%}: 128 \pm 10 \mathrm{~ms}\right.$; $\mathrm{n}=36)$ relative to $\mathrm{RyR} 2^{\mathrm{R} 4496 \mathrm{C}+/-}\left(\mathrm{RT}_{50 \%}: 86 \pm 5 \mathrm{~ms} ; \mathrm{n}=51 ; \mathrm{P}<0.05\right)$ and $\mathrm{WT}\left(\mathrm{RT}_{50 \%}: 79 \pm 5 \mathrm{~ms}\right.$; $\mathrm{n}=61 ; \mathrm{P}<0.05)$. However, there was no difference between $\mathrm{RyR} 2^{\mathrm{R} 4496 \mathrm{C}+/}$ and WT. Halfrelaxation time of $\mathrm{Ca}^{2+}$ decay at $1 \mathrm{~Hz}$ was significantly prolonged for CaMKII $\delta_{\mathrm{C}} / \mathrm{RyR}^{\mathrm{R} 4496 \mathrm{C}}\left(50 \% \mathrm{Ca}^{2+}\right.$ decay: $\left.109 \pm 4 \mathrm{~ms} ; \mathrm{n}=46\right)$ and CaMKII $\delta_{\mathrm{C}}\left(\mathrm{RT}_{50 \%}: 125 \pm 7\right.$ $\mathrm{ms} ; \mathrm{n}=36)$ myocytes as compared to $\mathrm{RyR} 2^{\mathrm{R} 4496 \mathrm{C}+/-}\left(50 \% \mathrm{Ca}^{2+}\right.$ decay: $90 \pm 3 \mathrm{~ms} ; \mathrm{n}=51$; $\mathrm{P}<0.05)$ and WT $\left(50 \% \mathrm{Ca}^{2+}\right.$ decay: $\left.98 \pm 3 \mathrm{~ms} ; \mathrm{n}=61 ; \mathrm{P}<0.05\right)$, but showed significantly faster $\mathrm{Ca}^{2+}$ removal from the cytosol in $\mathrm{RyR} 2^{\mathrm{R} 4496 \mathrm{C}+/-}$ versus WT. Prolongation in relaxation parameters which were observed in CaMKII $\delta_{C} / \mathrm{RyR} 2^{\mathrm{R} 4496 \mathrm{C}}$ double mutant and CaMKII $\delta_{\mathrm{C}}$ transgenic mice indicated an altered basal SR $\mathrm{Ca}^{2+}$ ATPase function. 
A

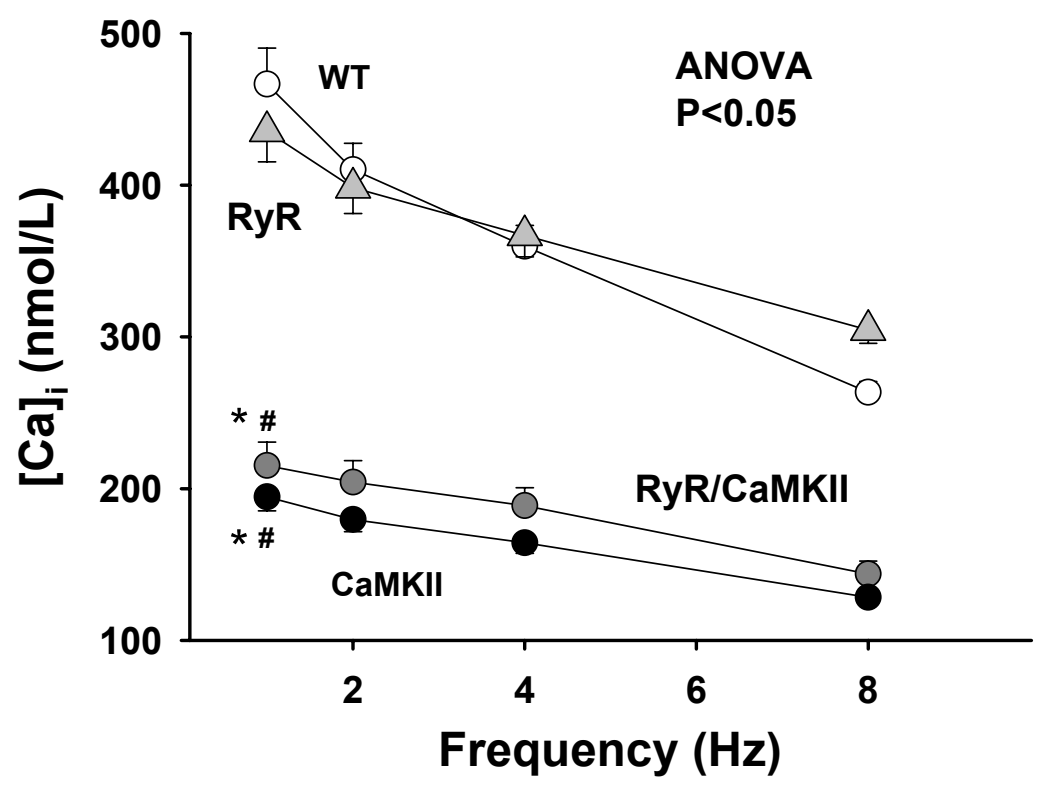

B

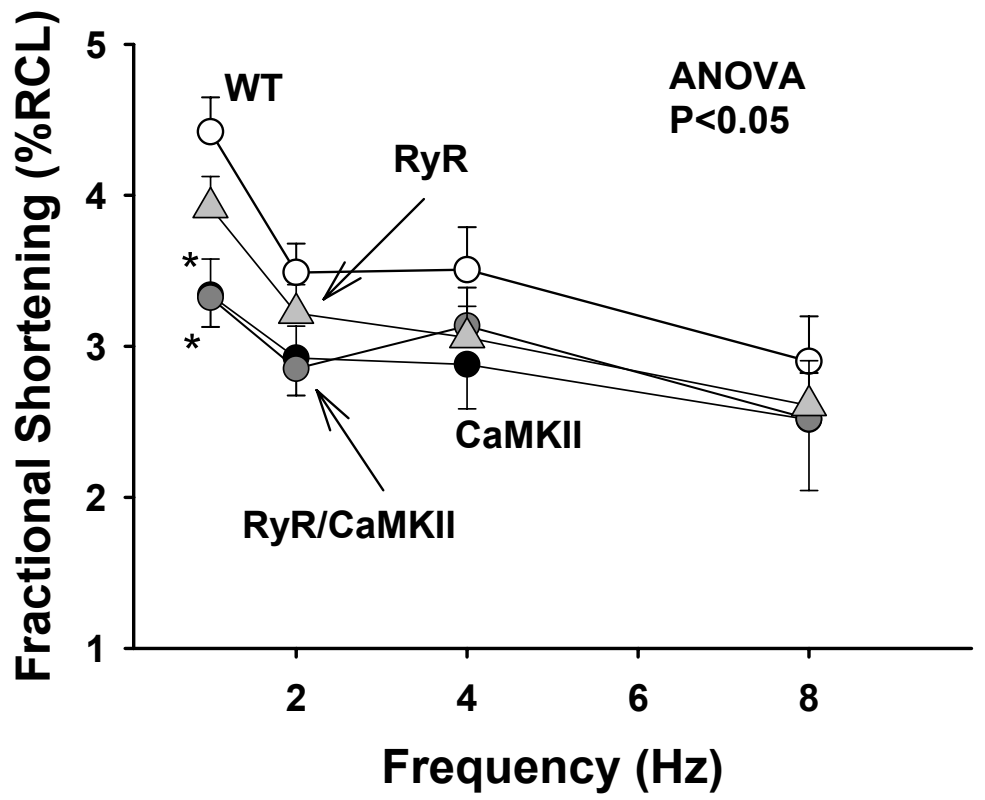

Figure 20. Frequency-dependent changes in $\mathrm{Ca}^{2+}$ transients and fractional shortening. Average values for (A) $\mathrm{Ca}^{2+}$ transients and (B) twitch shortening at increasing stimulation rates stepwise from $1 \mathrm{~Hz}$ to 2,4 and $8 \mathrm{~Hz}$ which led to decreased intracellular $\mathrm{Ca}^{2+}$ transients and fractional shortening in myocytes isolated from CaMKII $\delta_{\mathrm{C}} / \mathrm{RyR}^{\mathrm{R} 4496 \mathrm{C}}(\mathrm{n}=46)$ and $\mathrm{CaMKII} \delta_{\mathrm{C}}$ $(n=36)$ mice compared to RyR2 ${ }^{\mathrm{R} 4496 \mathrm{C}+/}(\mathrm{n}=51)$ and $\mathrm{WT}(\mathrm{n}=61)$ and showed negative staircase in all mice. ${ }^{*} \mathrm{P}<0.05$ (ANOVA) versus WT. \# $\mathrm{P}<0.05$ (ANOVA) versus $\mathrm{RyR} 2^{\mathrm{R} 4496 \mathrm{C}+/}$. 
A

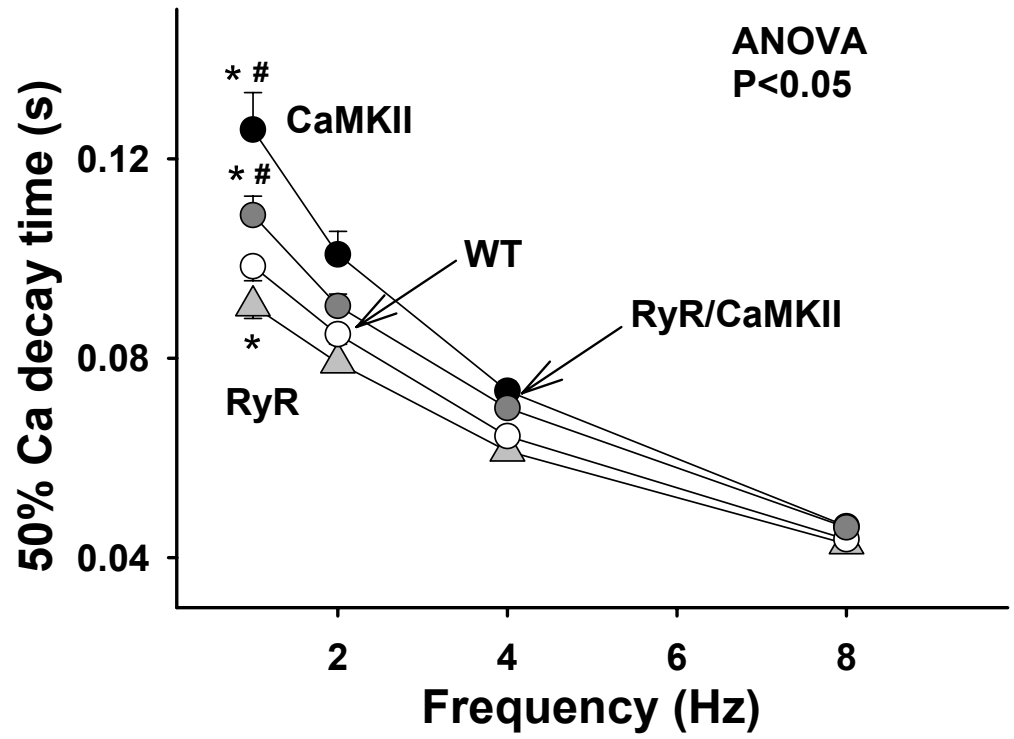

B

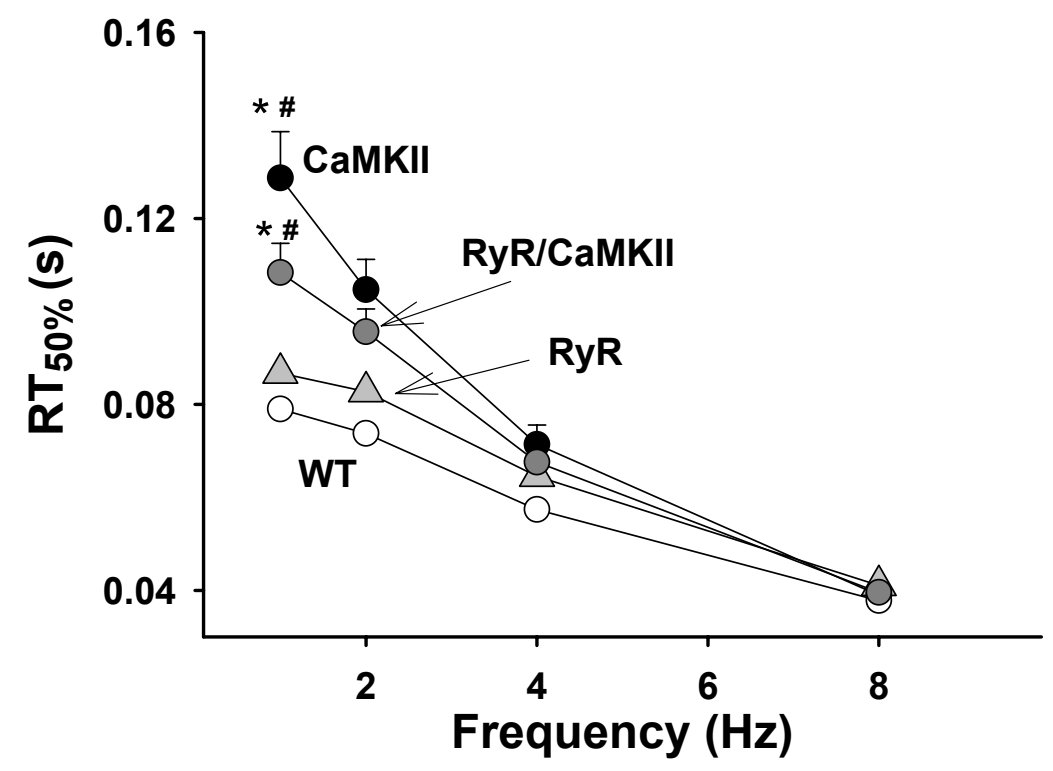

Figure 21. Frequency-dependent acceleration of relaxation. Mean data of half-relaxation time for (A) $\mathrm{Ca}^{2+}$ transient decay and (B) fractional shortening $\left(\mathrm{RT}_{50 \%}\right)$ at increasing stimulation rates stepwise from $1 \mathrm{~Hz}$ to 2,4 and to $8 \mathrm{~Hz}$ which were significantly prolonged in CaMKII $\delta_{\mathrm{C}} / \mathrm{RyR}^{\mathrm{R} 4496 \mathrm{C}}(\mathrm{n}=46)$ and CaMKII $\delta_{\mathrm{C}}(\mathrm{n}=36)$ myocytes versus RyR2 ${ }^{\mathrm{R} 4496 \mathrm{C}+/-}(\mathrm{n}=51)$ and WT ( $=61$ ). ${ }^{*} \mathrm{P}<0.05$ (ANOVA) versus WT. \# $\mathrm{P}<0.05$ (ANOVA) versus RyR2 ${ }^{\mathrm{R} 4496 \mathrm{C}+/}$. 
Frequency-dependent acceleration of relaxation (FDAR) is an intrinsic physiological mechanism, which allows more rapid ventricular diastolic filling at higher heart rates possibly due to CaMKII-dependent increased SR $\mathrm{Ca}^{2+}$ uptake (Maier and Bers, 2002). FDAR for $\mathrm{Ca}^{2+}$ transient amplitude and twitch shortening (measured in parallel) at $1 \mathrm{~Hz}$ to $8 \mathrm{~Hz}$ stimulation rates was apparent in all cells, but it was significantly enhanced in CaMKII $\delta_{\mathrm{C}} / \mathrm{RyR}^{\mathrm{R} 4496 \mathrm{C}}$ and CaMKII $\delta_{\mathrm{C}}$ myocytes versus RyR2 $2^{\mathrm{R} 4496 \mathrm{C}+/-}$ and WT. Halfrelaxation time in WT twitch shortening decreased from $79 \pm 5 \mathrm{~ms}$ at $1 \mathrm{~Hz}$ to $38 \pm 1 \mathrm{~ms}$ at 8 $\mathrm{Hz}$, in RyR2 $2^{\mathrm{R} 4496 \mathrm{C}+/-}$ from $89 \pm 4 \mathrm{~ms}$ at $1 \mathrm{~Hz}$ to $41 \pm 1 \mathrm{~ms}$ at $8 \mathrm{~Hz}$, in CaMKII $\delta_{\mathrm{C}} / \mathrm{RyR}^{\mathrm{R} 4496 \mathrm{C}}$ from $108 \pm 6 \mathrm{~ms}$ at $1 \mathrm{~Hz}$ to $40 \pm 1 \mathrm{~ms}$ at $8 \mathrm{~Hz}$ and in CaMKIII $\delta_{\mathrm{C}}$ from $128 \pm 10 \mathrm{~ms}$ at $1 \mathrm{~Hz}$ to $39 \pm 2 \mathrm{~ms}$ at $8 \mathrm{~Hz}$. Half-relaxation time of $\mathrm{Ca}^{2+}$ decay declined from $98 \pm 3 \mathrm{~ms}$ at $1 \mathrm{~Hz}$ to $44 \pm 1 \mathrm{~ms}$ at $8 \mathrm{~Hz}$ in WT, $90 \pm 3 \mathrm{~ms}$ at $1 \mathrm{~Hz}$ to $43 \pm 1 \mathrm{~ms}$ at $8 \mathrm{~Hz}$ in RyR2 ${ }^{\mathrm{R} 4496 \mathrm{C}+/}, 109 \pm 4 \mathrm{~ms}$ at $1 \mathrm{~Hz}$ to $46 \pm 1 \mathrm{~ms}$ at $8 \mathrm{~Hz}$ in CaMKII $\delta_{\mathrm{C}} / \mathrm{RyR} 2^{\mathrm{R} 4496 \mathrm{C}}$ and from $125 \pm 7 \mathrm{~ms}$ at $1 \mathrm{~Hz}$ to $46 \pm 1 \mathrm{~ms}$ at $8 \mathrm{~Hz}$ in CaMKII $\delta_{\mathrm{C}}$. The index of FDAR (as ratio of $\mathrm{Ca}^{2+}$ decline and twitch shortening at $8 \mathrm{~Hz}$ versus $1 \mathrm{~Hz}$ ) was $0.42 \pm 0.3$ in CaMKIII $\delta_{\mathrm{C}} / \mathrm{RyR}^{\mathrm{R} 4496 \mathrm{C}}$ and $0.37 \pm 0.1$ in CaMKII $\delta_{\mathrm{C}}$ versus $0.47 \pm 0.3$ in $\mathrm{RyR} 2^{\mathrm{R} 4496 \mathrm{C}+/}$ and $0.45 \pm 0.3$ in WT cardiac myocytes. However, it was even more dramatic for FDAR of shortening with $0.37 \pm 0.2$ in CaMKII $\delta_{\mathrm{C}} / \mathrm{RyR}^{\mathrm{R} 4496 \mathrm{C}}$ and $0.30 \pm 0.2$ versus $0.46 \pm 0.2$ in $\mathrm{RyR} 2^{\mathrm{R} 4496 \mathrm{C}+/}$ and $0.48 \pm 0.2$ in WT.

\subsubsection{SR $\mathrm{Ca}^{2+}$ content and NCX function}

To analyze whether altered $\mathrm{Ca}^{2+}$ transient amplitudes in CaMKII $\delta_{\mathrm{C}} / \mathrm{RyR} 2^{\mathrm{R} 4496 \mathrm{C}}$ and CaMKIII $\delta_{\mathrm{C}}$ mice result from changes of SR $\mathrm{Ca}^{2+}$ content, we measured caffeine-induced $\mathrm{Ca}^{2+}$ transients. Application of caffeine caused a rapid increase in intracellular $\mathrm{Ca}^{2+}$ concentration as a result of sudden $\mathrm{SR} \mathrm{Ca}^{2+}$ release. As shown by the original traces in Figure $22, \mathrm{Ca}^{2+}$ transient amplitude after rapid application of caffeine was significantly decreased in CaMKII $\delta_{\mathrm{C}} / \mathrm{RyR}^{\mathrm{R} 4496 \mathrm{C}}$ and $\mathrm{CaMKII} \delta_{\mathrm{C}}$ versus $\mathrm{RyR} 2^{\mathrm{R} 4496 \mathrm{C}+/-}$ and WT myocytes. Average data (Fig. 23) show that the caffeine-induced $\mathrm{Ca}^{2+}$ transient after $1 \mathrm{~Hz}$ stimulation in RyR2 $2^{\mathrm{R} 4496 \mathrm{C}+/}(932.60 \pm 89.44 \mathrm{nM} ; \mathrm{n}=31)$ was not significantly different from WT (1065.44 $\pm 46.49 \mathrm{nM} ; \mathrm{n}=24)$. However, the $\mathrm{Ca}^{2+}$ transient after caffeine application was significantly smaller by $36 \%$ in CaMKIII $\delta_{C} / \mathrm{RyR}^{\mathrm{R} 4496 \mathrm{C}}(383.00 \pm 16.77 \mathrm{nM} ; \mathrm{n}=23)$ and by $34 \%$ in CaMKII $\delta_{\mathrm{C}}(361.22 \pm 24.52 \mathrm{nM} ; \mathrm{n}=20)$ myocytes as compared to RyR2 $2^{\mathrm{R} 4496 \mathrm{C}+/-}$ $(\mathrm{P}<0.05)$ and WT $(\mathrm{P}<0.05)$, suggesting a dramatically decreased $\mathrm{SR} \mathrm{Ca}^{2+}$ content in these double mutant and transgenic mice. This may explain the reduction in $\mathrm{Ca}^{2+}$ transient amplitude and impairment of contractile function of intact myocytes isolated from $\mathrm{CaMKII} \delta_{\mathrm{C}} / \mathrm{RyR}^{\mathrm{R} 4496 \mathrm{C}}$ and CaMKII $\delta_{\mathrm{C}}$ mice. 


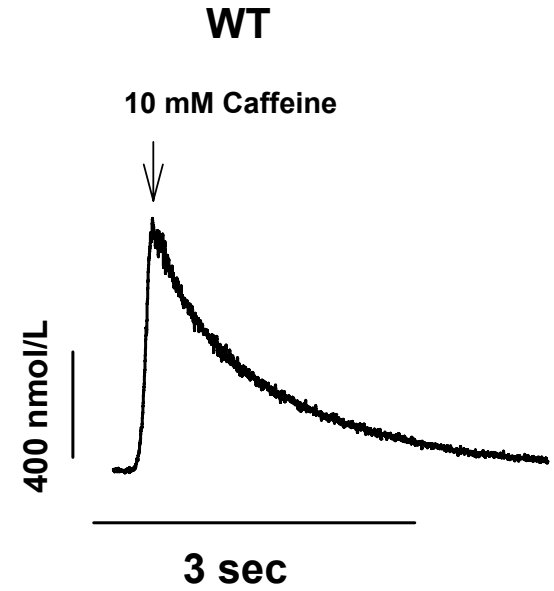

RyR/CaMKII

$10 \mathrm{mM}$ Caffeine<smiles>C1CC1</smiles>

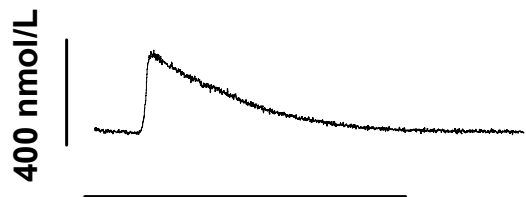

$3 \mathrm{sec}$
RyR

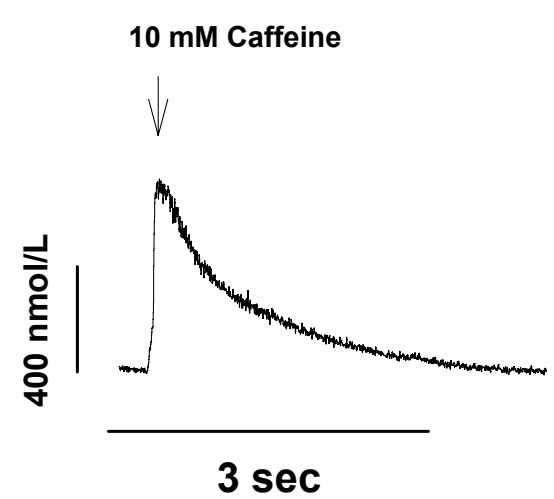

CaMKII

$10 \mathrm{mM}$ Caffeine

$\downarrow$

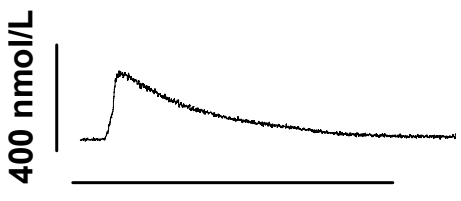

$3 \mathrm{sec}$

Figure 22. Caffeine-induced $\mathrm{Ca}^{2+}$ transients. Representative $\mathrm{Ca}^{2+}$ traces after rapid application of $10 \mathrm{mM}$ caffeine at a stimulation frequency of $1 \mathrm{~Hz}$ showing decreased $\mathrm{SR} \mathrm{Ca}^{2+}$ content in CaMKII $\delta_{\mathrm{C}} / \mathrm{RyR}^{\mathrm{R} 4496 \mathrm{C}}$ and CaMKII $\delta_{\mathrm{C}}$ myocytes versus RyR2 $2^{\mathrm{R} 4496 \mathrm{C}+/}$ and WT.

The subsequent decline of intracellular $\mathrm{Ca}^{2+}$ concentration during caffeine application results from extrusion of $\mathrm{Ca}^{2+}$ across the sarcolemma mainly via NCX and thus allows to assess NCX function by determining the exponential rate time-constant (tau) of $\mathrm{Ca}^{2+}$ transient amplitude decline (Bers, 2001). There was a tendency for increased NCX function in RyR2 ${ }^{\text {R4496C+/- }}$ (tau $1.01 \pm 0.07 \mathrm{sec} ; \mathrm{n}=31$ ), CaMKII $\delta_{\mathrm{C}} / \mathrm{RyR}^{\mathrm{R} 4496 \mathrm{C}}$ (tau $0.99 \pm 0.12$ sec; $\mathrm{n}=23$ ) and $\mathrm{CaMKII} \delta_{\mathrm{C}}($ tau $1.04 \pm 0.06 \mathrm{sec} ; \mathrm{n}=16$ ) mice versus WT (tau $1.15 \pm 0.07 \mathrm{sec}$; $\mathrm{n}=24$ ), but the data did not reach significant differences (Fig. 24). 


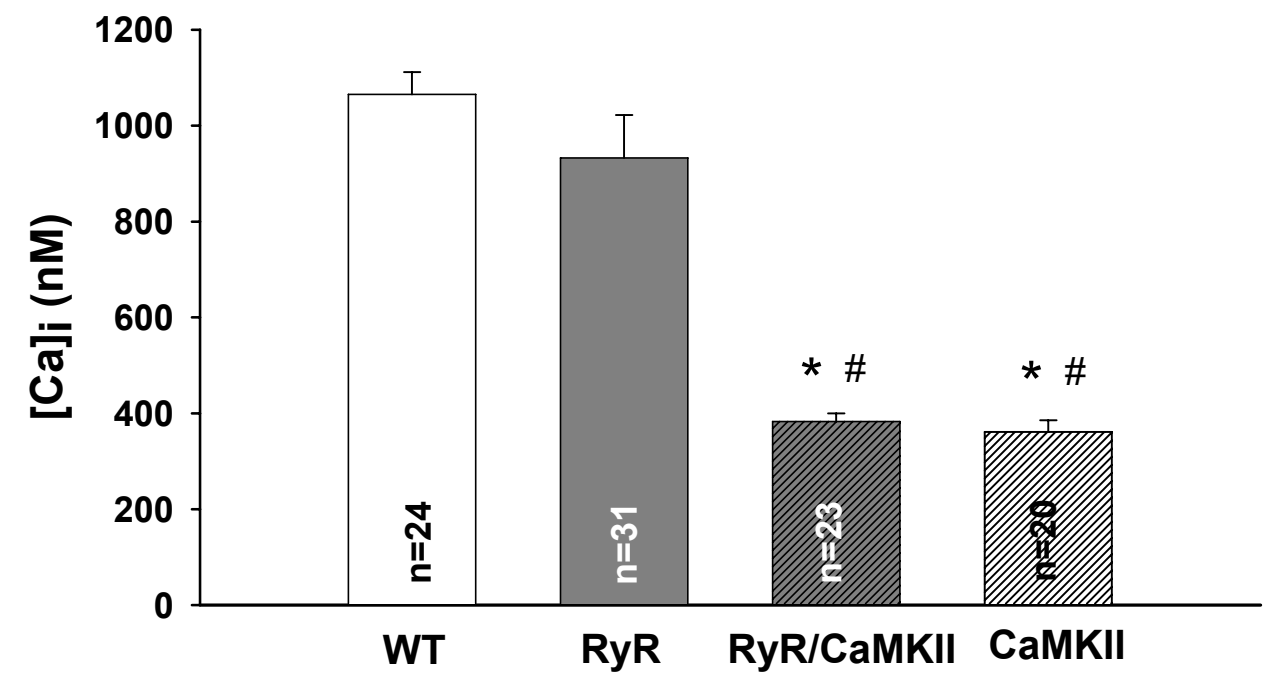

Figure 23. SR $\mathrm{Ca}^{2+}$ content in cardiomyocytes. Average data for caffeine-induced $\mathrm{Ca}^{2+}$ transients showing a dramatic decrease in $\mathrm{SR} \mathrm{Ca}^{2+}$ content in isolated cardiomyocytes from CaMKII $\delta_{\mathrm{C}} / \mathrm{RyR}^{2}{ }^{\mathrm{R} 446 \mathrm{C}}, \mathrm{CaMKII}_{\mathrm{C}}$ versus RyR2 $2^{\mathrm{R} 4496 \mathrm{C}+/-}$ and WT mice. ${ }^{*} \mathrm{P}<0.05$ versus WT. \# $\mathrm{P}<0.05$ versus $\mathrm{RyR} 2^{\mathrm{R} 4496 \mathrm{C}+/}$.

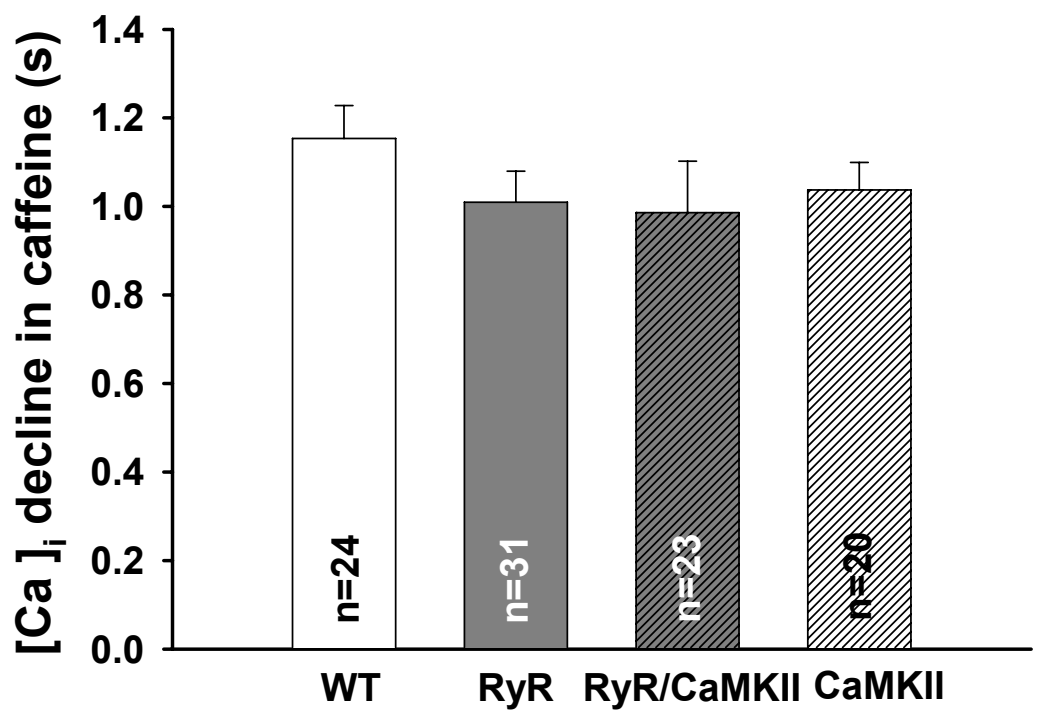

Figure 24. NCX function. Mean data for $\mathrm{Ca}^{2+}$ transient decline during caffeine-induced $\mathrm{Ca}^{2+}$ transients indicating a slightly increased NCX function in RyR2 ${ }^{\mathrm{R} 4496 \mathrm{C}+/}, \mathrm{CaMKII} \delta_{\mathrm{C}} / \mathrm{RyR}^{\mathrm{R} 4496 \mathrm{C}}$ and CaMKII $\delta_{\mathrm{C}}$ myocytes. 
The ratio of individual twitch $\mathrm{Ca}^{2+}$ transient amplitude/caffeine-induced $\mathrm{Ca}^{2+}$ transient (an index of SR fractional $\mathrm{Ca}^{2+}$ release, or amount of $\mathrm{Ca}^{2+}$ released during a twitch versus that $\mathrm{Ca}^{2+}$ stored in the SR) was significantly increased in CaMKII $\delta_{C} / \mathrm{RyR}^{\mathrm{R} 4496 \mathrm{C}}(63.21 \pm 2.20$; $\mathrm{n}=23)$ and $\mathrm{CaMKII} \delta_{\mathrm{C}}(61.69 \pm 2.24 ; \mathrm{n}=17)$ versus WT cardiomyocytes $(48.30 \pm 1.63 ; \mathrm{n}=24$; $\mathrm{P}<0.05$ ), even though the lower $\mathrm{SR} \mathrm{Ca}^{2+}$ content by itself would tend to greatly reduce fractional SR $\mathrm{Ca}^{2+}$ release (Fig. 25). This is usually found in CaMKII overexpressing cardiomyocytes due to CaMKII-dependent RyR2 phosphorylation. Thus, whereas SR $\mathrm{Ca}^{2+}$ content was reduced in CaMKII $\delta_{\mathrm{C}} / \mathrm{RyR} 2^{\mathrm{R} 4496 \mathrm{C}}$ and CaMKII $\delta_{\mathrm{C}}$ myocytes, the fraction of SR $\mathrm{Ca}^{2+}$ released during a twitch was increased. Interestingly, the fractional $\mathrm{SR} \mathrm{Ca}^{2+}$ release in $\mathrm{RyR}^{\mathrm{R} 4496 \mathrm{C}+/}(60.94 \pm 2.24 ; \mathrm{n}=31)$ was also dramatically augmented as compared to WT and this abnormal $\mathrm{Ca}^{2+}$ release could be attributed to $\mathrm{R} 4496 \mathrm{C}$ mutation in the gene encoding RyR2.

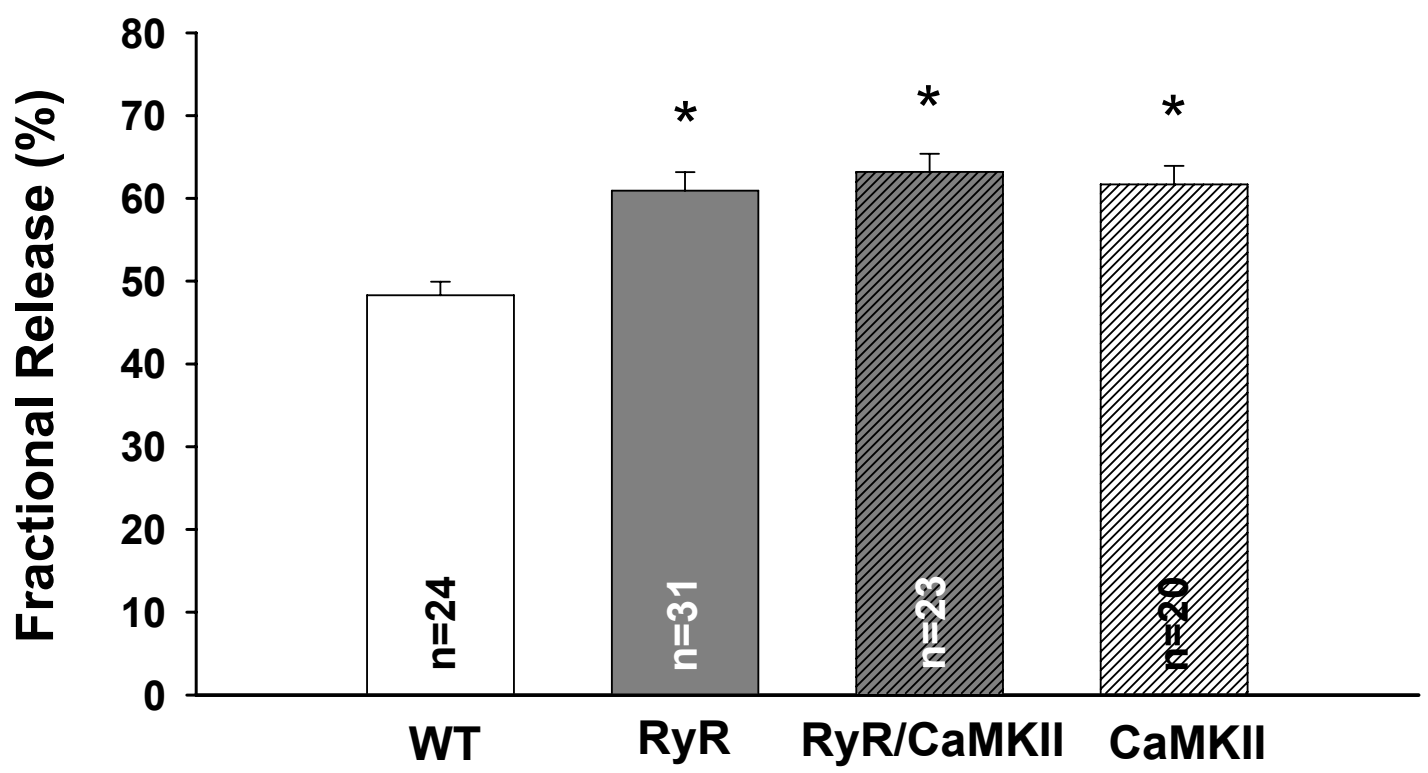

Figure 25. Fractional SR $\mathrm{Ca}^{2+}$ release. Average data for fractional $\mathrm{SR} \mathrm{Ca}^{2+}$ release (ratio of twitch $\mathrm{Ca}^{2+}$ transient/caffeine-induced $\mathrm{Ca}^{2+}$ transient) showing an increased fraction of $\mathrm{SR} \mathrm{Ca}^{2+}$ released during a twitch in RyR2 ${ }^{\mathrm{R} 4496 \mathrm{C}+/}$, CaMKII $\delta_{\mathrm{C}} / \mathrm{RyR}^{\mathrm{R} 4496 \mathrm{C}}$ and CaMKII $\delta_{\mathrm{C}}$ myocytes versus WT. ${ }^{*} \mathrm{P}<0.05$ versus WT. 


\subsection{Expression levels of important $\mathrm{Ca}^{2+}$ transport proteins in mouse hearts}

To investigate whether phenotypic changes as well as functional alterations observed in $\mathrm{RyR} 2^{\mathrm{R} 4496 \mathrm{C}+/}$ and $\mathrm{CaMKII} \delta_{\mathrm{C}} / \mathrm{RyR} 2^{\mathrm{R} 4496 \mathrm{C}}$ mice could be associated with altered expression levels of important $\mathrm{Ca}^{2+}$ transport proteins such as SERCA2a, PLB, NCX and CSQ, Western blot measurements were performed. Protein homogenates prepared from RyR2 ${ }^{\text {R4496C+/- }}$ knock-in, CaMKIII $\delta_{C} /$ RyR2 $^{\text {R4496C }}$ double mutant and WT mouse hearts were denatured in sample buffer containing $2 \% \beta$-mercaptoethanol and subjected to SDSpolyacrylamide gel. Immunoblotting with the antibody against SERCA2a (Affinity Bioreagents), PLB (Upstate), NCX (Swant) and CSQ (Affinity Bioreagents) revealed significantly increased expression levels of SERCA2a by $125 \%$ and PLB by $167 \%$ ( $n=5$; $\mathrm{P}<0.05)$ in homogenates prepared from $\mathrm{RyR} 2^{\mathrm{R} 4496 \mathrm{C}+/}$ knock-in mouse hearts versus WT when normalized to GAPDH. The SERCA2a/PLB ratio remained however unchanged, indicating unaltered SR $\mathrm{Ca}^{2+}$ uptake function. Expression levels of two other $\mathrm{Ca}^{2+}$ handling proteins, NCX and CSQ, were also not significantly altered (Fig. 26).

In $\mathrm{CaMKII} \delta_{\mathrm{C}} / \mathrm{RyR}^{\mathrm{R} 4496 \mathrm{C}}$ double mutant mouse hearts a reduced expression of SERCA2a by $37 \%(n=8 ; P<0.05)$ was observed, whereas PLB $(n=8)$ and $\operatorname{NCX}(n=8)$ expression levels were unaltered. The SERCA2a/PLB ratio was lower by $36 \%$ in the CaMKII $\delta_{\mathrm{C}} / \mathrm{RyR}^{\mathrm{R} 4496 \mathrm{C}}$ double mutant as well $(\mathrm{P}=0.08)$, indicating a slightly greater $\mathrm{Ca}^{2+}$-pump inhibition as compared to WT. Interestingly, we also found decreased expression levels of calsequestrin $(\mathrm{n}=8$; by $39 \%$; $\mathrm{P}<0.05)$ in $\mathrm{CaMKII} \delta_{\mathrm{C}} / \mathrm{RyR}^{\mathrm{R} 4496 \mathrm{C}}$ mice. GAPDH served as control of equal loading (Fig. 27). 
A

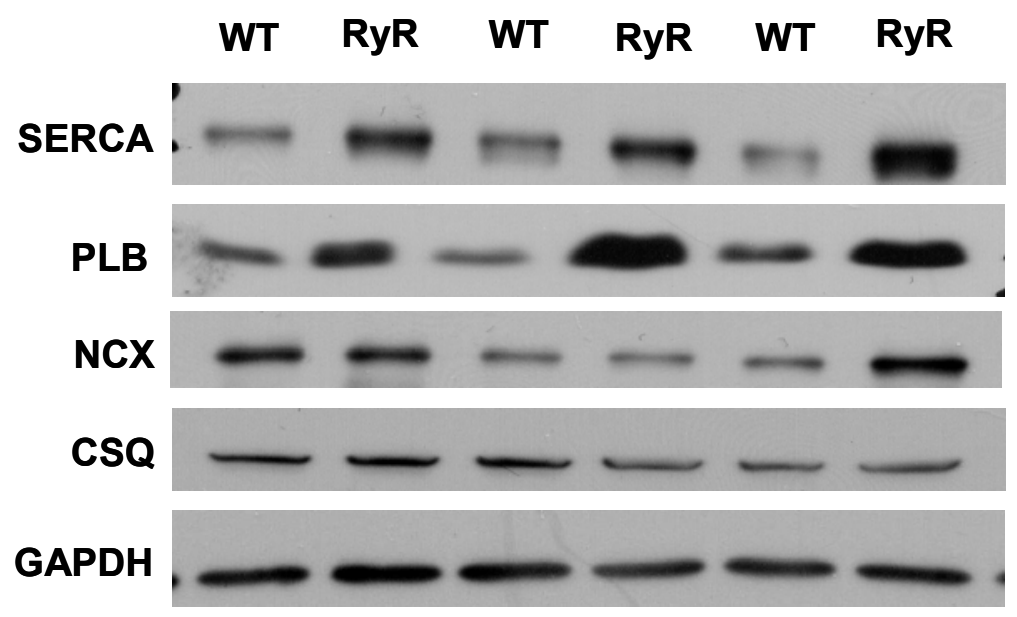

B

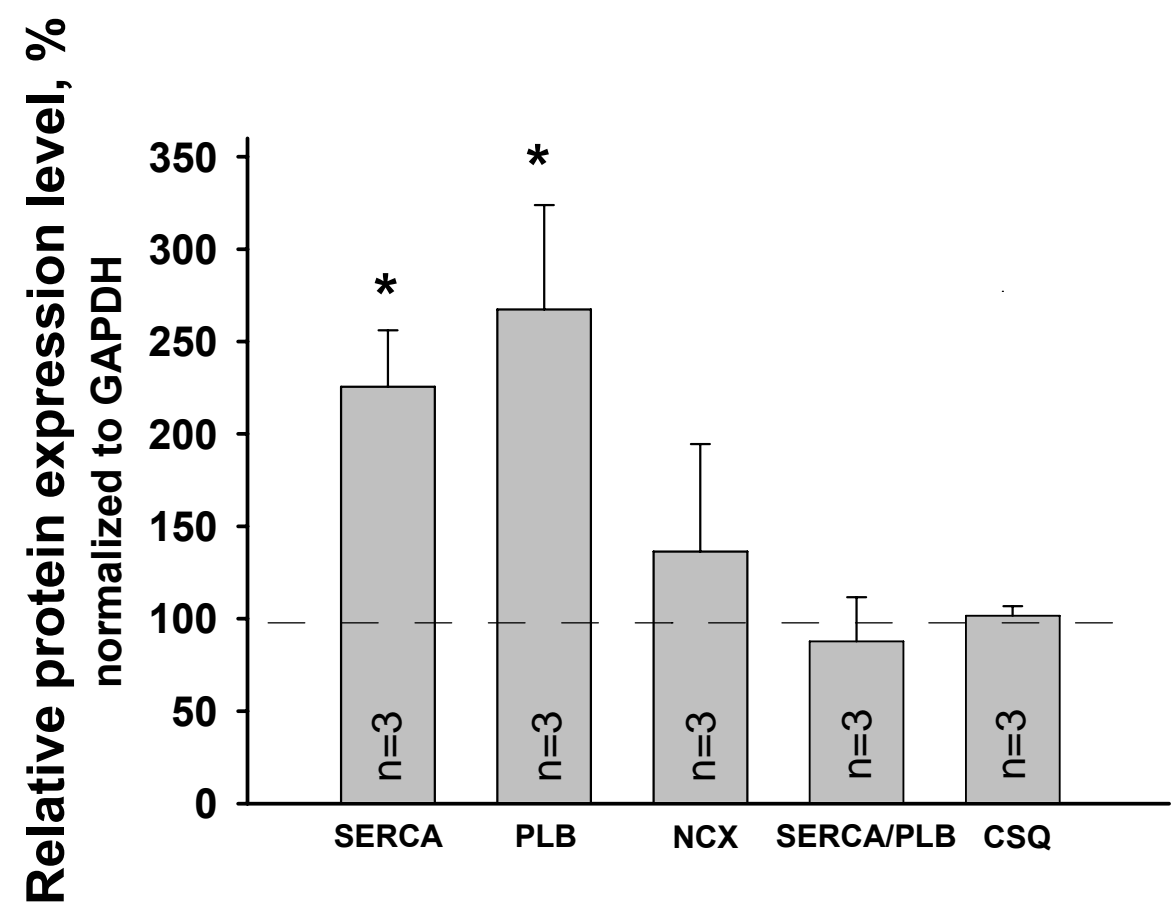

Protein expression level in WT was set to $100 \%$

Figure 26. (A) Representative Western blots of important $\mathrm{Ca}^{2+}$ cycling proteins from cardiac homogenates prepared from hearts of $\mathrm{RyR2}^{\mathrm{R} 4496 \mathrm{C}+/}$ and WT mice. Cardiac homogenates from WT and RyR2 $2^{\mathrm{R} 4496 \mathrm{C}+/}$ mice were warmed in the sample buffer containing $2 \% \beta$-mercaptoethanol, separated on $10 \%$ and $15 \%$ polyacrylamide-SDS gels and transferred to nitrocellulose. Western blots were probed with anti-SERCA2a, anti-PLB, anti-NCX, anti-CSQ and anti-GAPDH antibodies. (B) Quantification of the protein expression level in RyR2 ${ }^{\mathrm{R} 4496 \mathrm{C}+/}$ versus WT mice. A significantly increased expression of SERCA2a (by 125\%) and PLB (by 167\%) was observed in RyR2 ${ }^{\text {R4496C+/- }}$ versus WT. The amount of the proteins was determined densitometrically and normalized to GAPDH. $* \mathrm{P}<0.05$ versus WT. 
A

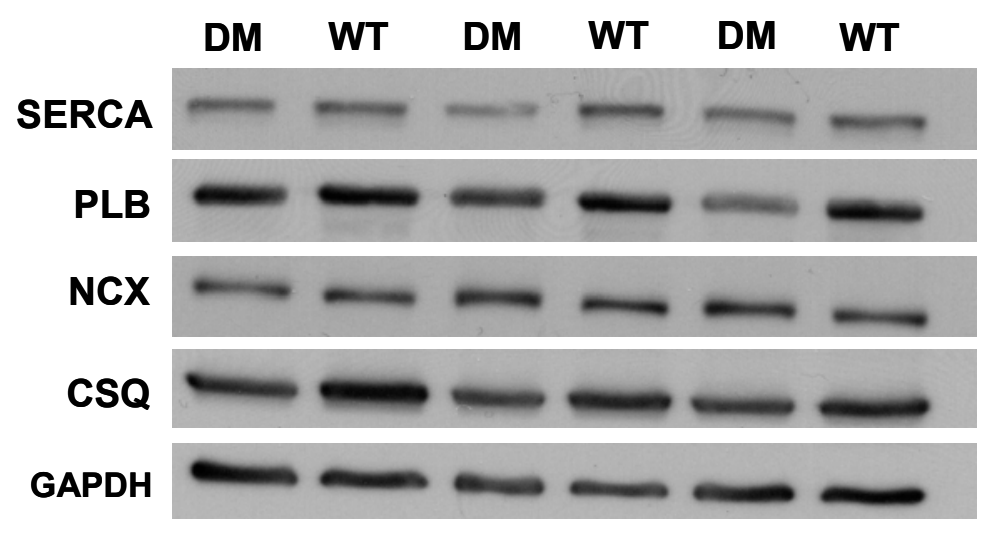

B

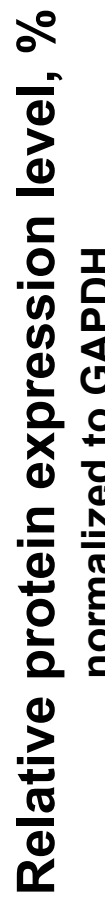

120

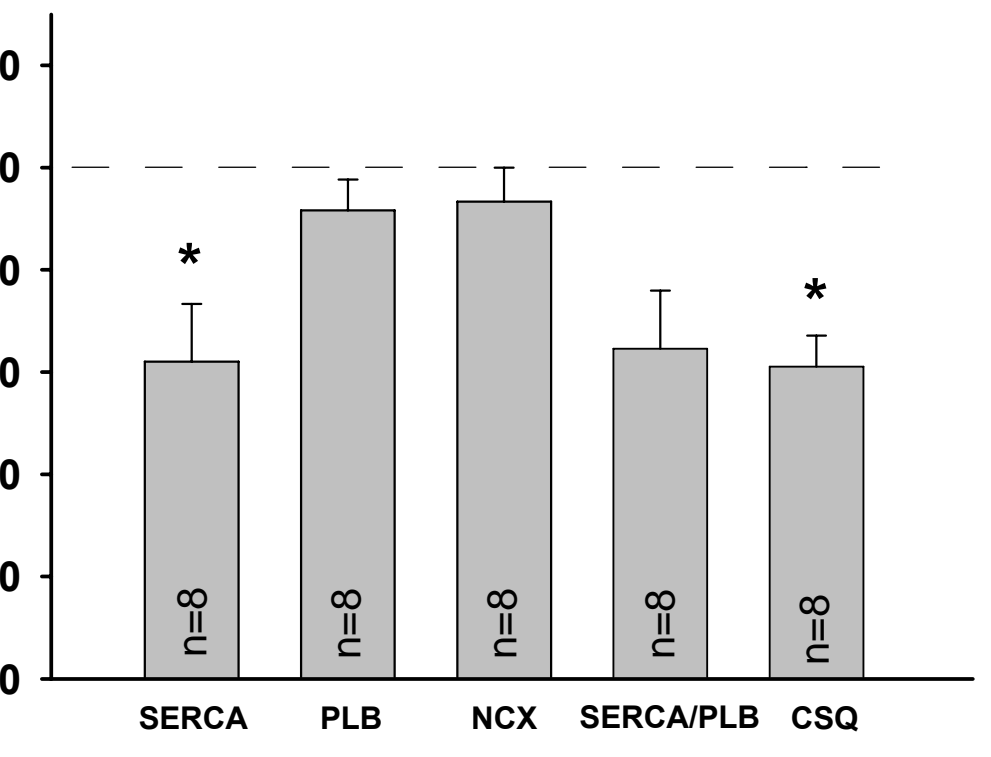

Protein expression level in WT was set to $100 \%$

Figure 27. (A) Representative Western blots of important $\mathrm{Ca}^{2+}$ cycling proteins from cardiac homogenates prepared from hearts of $\mathrm{CaMKII} \delta_{\mathrm{C}} / \mathrm{RyR2}^{\mathrm{R4496C}}$ and WT mice. Cardiac homogenates from WT and CaMKII $\delta_{C} / \mathrm{RyR}^{\mathrm{R} 4496 \mathrm{C}}$ mice were warmed in the sample buffer containing $2 \% \beta$-mercaptoethanol, separated on $10 \%$ and $15 \%$ polyacrylamide-SDS gels and transferred to nitrocellulose. Western blots were probed with anti-SERCA2a, anti-PLB, anti-NCX, anti-CSQ and anti-GAPDH antibodies. (B) Quantification of the protein expression level in CaMKIII $\delta_{C} /$ RyR2 $^{\text {R4496C }}$ versus WT mice. There was a significantly lower expression of SERCA2a (by 37\%) and CSQ (by 39\%) in CaMKII $\delta_{C} / \mathrm{RyR}^{\mathrm{R} 4496 \mathrm{C}}$ versus WT. The amount of the proteins was determined densitometrically and normalized to GAPDH. * $\mathrm{P}<0.05$ versus WT. 


\subsection{Measurement of $\mathrm{Ca}^{2+}$ release from the $\mathrm{SR}$ using confocal microscopy}

The activity of individual RyR2 clusters generates localized $\mathrm{Ca}^{2+}$ release events termed $\mathrm{Ca}^{2+}$ sparks. The frequency, amplitude and time course of $\mathrm{Ca}^{2+}$ sparks contributes to the spontaneous $\mathrm{Ca}^{2+}$ leak from the SR.

$\mathrm{Ca}^{2+}$ sparks were recorded on a laser scanning confocal microscope (LSM 5 Pascal, Zeiss) using intact cardiomyocytes loaded with the $\mathrm{Ca}^{2+}$-fluorescent dye Fluo-4 AM. The dye was excited by an argon laser at $488 \mathrm{~nm}$ and emitted fluorescence was collected through a 515 $\mathrm{nm}$ long-pass emission filter. Figure 28A shows representative line scan images from WT, $\mathrm{RyR}^{\mathrm{R} 4496 \mathrm{C}+/}$, CaMKII $\delta_{\mathrm{C}} / \mathrm{RyR}^{\mathrm{R} 4496 \mathrm{C}}$ and $\mathrm{CaMKIII}_{\mathrm{C}}$ myocytes during perfusion with normal Tyrode solution containing $3 \mathrm{mM} \mathrm{Ca}^{2+}$. One would expect that a reduction in SR $\mathrm{Ca}^{2+}$ load leads to a decrease of spontaneous $\mathrm{SR} \mathrm{Ca}^{2+}$ release events in CaMKII $\delta_{C} /$ RyR $^{\mathrm{R} 4496 \mathrm{C}}$ and CaMKII $\delta_{\mathrm{C}}$ myocytes. Strikingly, the opposite was observed: $\mathrm{CaSpF}$ during $0.5 \mathrm{~Hz}$ stimulation was significantly increased by $\approx 50 \%$ in $\mathrm{CaMKII}_{\mathrm{C}} / \mathrm{RyR}^{\mathrm{R} 4496 \mathrm{C}}\left(2.26 \pm 0.23 \mathrm{pl}^{-1} * \mathrm{~s}^{-1} ; \mathrm{n}=60\right)$ and CaMKIII $\delta_{\mathrm{C}}\left(2.45 \pm 0.26 \mathrm{pl}^{-1} * \mathrm{~s}^{-1} ; \mathrm{n}=53\right)$ versus WT mice $\left(1.14 \pm 0.1 \mathrm{pl}^{-1} * \mathrm{~s}^{-1} ; \mathrm{n}=46 ; \mathrm{P}<0.05\right)$. CaSpF in $\mathrm{RyR} 2^{\mathrm{R} 4496 \mathrm{C}+/}$ knock-in mice $\left(2.22 \pm 0.20 \mathrm{pl}^{-1} * \mathrm{~s}^{-1} ; \mathrm{n}=68\right)$ was also significantly higher than in $\mathrm{WT}(\mathrm{P}<0.05)$, probably due to the mutated RyR2 (Fig. 28B). Additionally, significant changes in $\mathrm{Ca}^{2+}$ spark characteristics were observed. The $\mathrm{Ca}^{2+}$ spark amplitude $\left(\mathrm{F} / \mathrm{F}_{0}\right)$ was increased to the same level in CaMKII $\delta_{C} / \mathrm{RyR}^{\mathrm{R} 4496 \mathrm{C}}(1.70 \pm 0.02 ; \mathrm{n}=178)$ and $\mathrm{RyR} 2^{\mathrm{R} 4496 \mathrm{C}+/}(1.70 \pm 0.02 ; \mathrm{n}=192)$ myocytes versus WT $(1.57 \pm 0.02 ; \mathrm{n}=67 ; \mathrm{P}<0.05)$. This is expected, because usually $\mathrm{Ca}^{2+}$ spark frequency and amplitude are altered in the same direction. Nevertheless, in CaMKII $\delta_{\mathrm{C}}$ transgenic mice $(1.60 \pm 0.02 ; \mathrm{n}=171)$ the $\mathrm{Ca}^{2+}$ spark amplitude was not much higher than in WT control. Lower $\mathrm{Ca}^{2+}$ spark amplitude in these mice is consistent with the lower SR $\mathrm{Ca}^{2+}$ content (Fig. 29A). The duration of the $\mathrm{Ca}^{2+}$ sparks was significantly prolonged in RyR2 ${ }^{\mathrm{R} 4496 \mathrm{C}+-}$ knock-in $(91.78 \pm 3.56 \mathrm{~ms} ; \mathrm{n}=183)$, CaMKII $\delta_{\mathrm{C}} / \mathrm{RyR}^{\mathrm{R} 4496 \mathrm{C}}$ double mutant $(92.23 \pm 3.66 \mathrm{~ms} ; \mathrm{n}=175)$ and $\mathrm{CaMKII} \delta_{\mathrm{C}}$ transgenic myocytes $(106 \pm 4.56 \mathrm{~ms}$; $\mathrm{n}=166)$ relative to WT $(75.55 \pm 4.28 \mathrm{~ms} ; \mathrm{n}=65 ; \mathrm{P}<0.05)$, suggesting longer RyR2 openings (Fig. 29B). These increases in frequency, amplitude and duration of $\mathrm{Ca}^{2+}$ sparks suggest a severely altered diastolic RyR2 function. The much higher frequency of long $\mathrm{Ca}^{2+}$ sparks with increased spark amplitude may reflect a higher propensity for the initiation of delayed afterdepolarizations and consequent triggered arrhythmias in $\mathrm{CaMKII}_{\mathrm{C}} / \mathrm{RyR}^{\mathrm{R} 4496 \mathrm{C}}$ double mutant mice. 


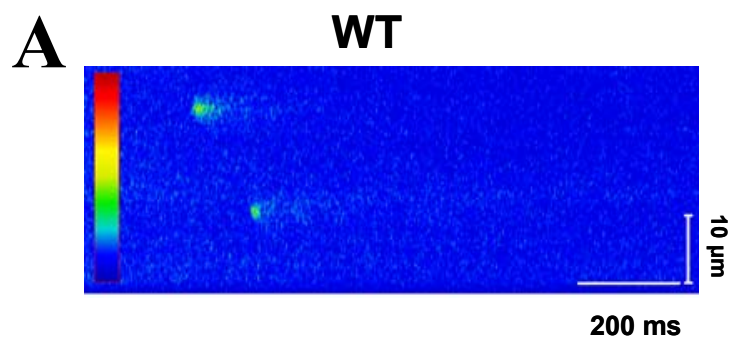

RyR/CaMKII

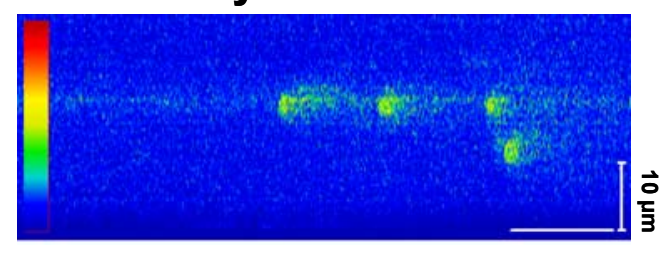

$200 \mathrm{~ms}$

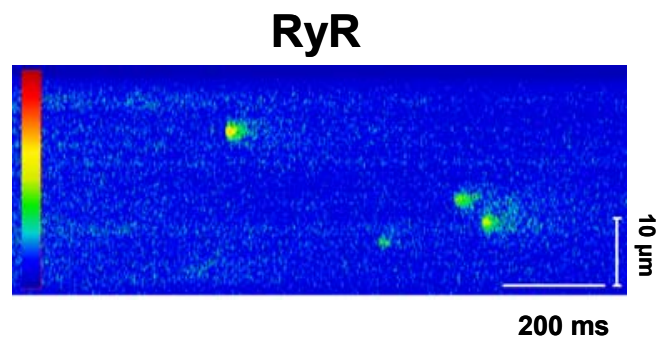

CaMKII

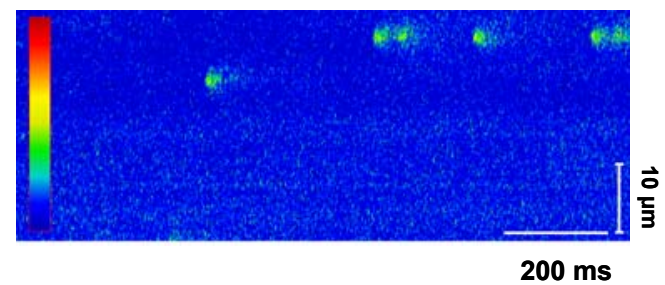

B

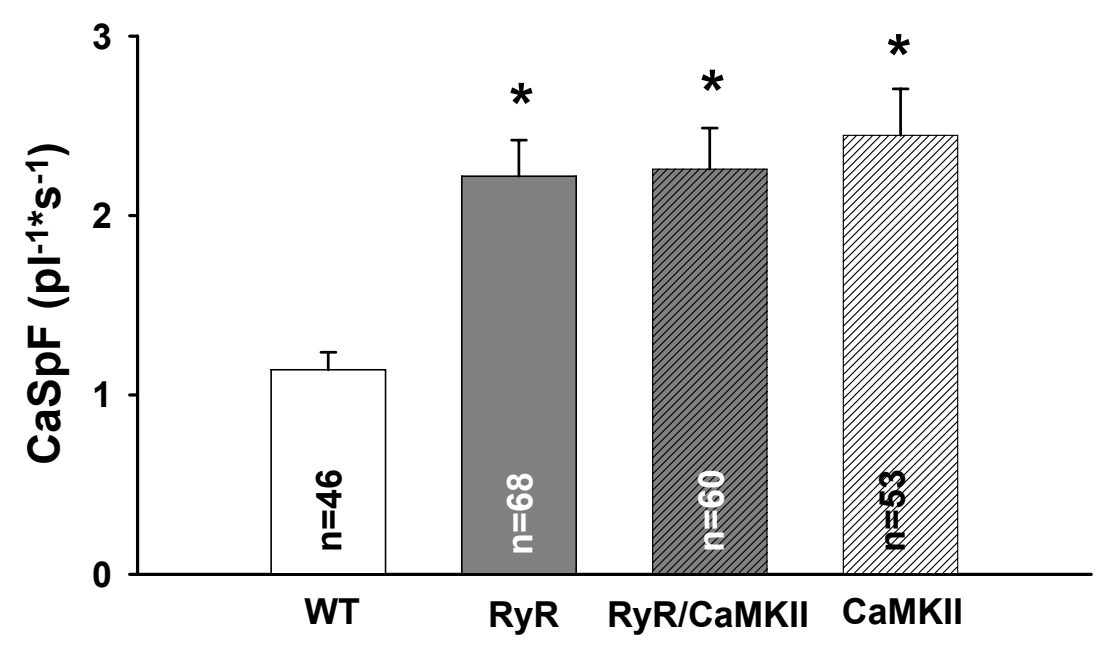

Figure 28. $\mathrm{Ca}^{2+}$ sparks in mouse ventricular myocytes measured using Fluo-4. (A) Confocal line scan images of spontaneous $\mathrm{Ca}^{2+}$ sparks in WT, RyR2 ${ }^{\mathrm{R} 4496 \mathrm{C}+/}, \mathrm{CaMKII} \delta_{\mathrm{C}} / \mathrm{RyR} 2^{\mathrm{R} 4496 \mathrm{C}}$ and CaMKII $\delta_{\mathrm{C}}$ myocytes, as a measure of diastolic RyR2 activity $\left(\mathrm{Ca}^{2+}\right.$ leak). (B) Average data for $\mathrm{Ca}^{2+}$ spark frequency $(\mathrm{CaSpF})$ showing dramatically increased spontaneous $\mathrm{SR} \mathrm{Ca}^{2+}$ release in cardiomyocytes isolated from RyR2 $2^{\mathrm{R} 4496 \mathrm{C}+/}, \mathrm{CaMKII} \delta_{\mathrm{C}} / \mathrm{RyR} 2^{\mathrm{R} 4496 \mathrm{C}}$ and CaMKII $\delta_{\mathrm{C}}$ mice compared to $\mathrm{WT}$. $* \mathrm{P}<0.05$ versus WT. 
A
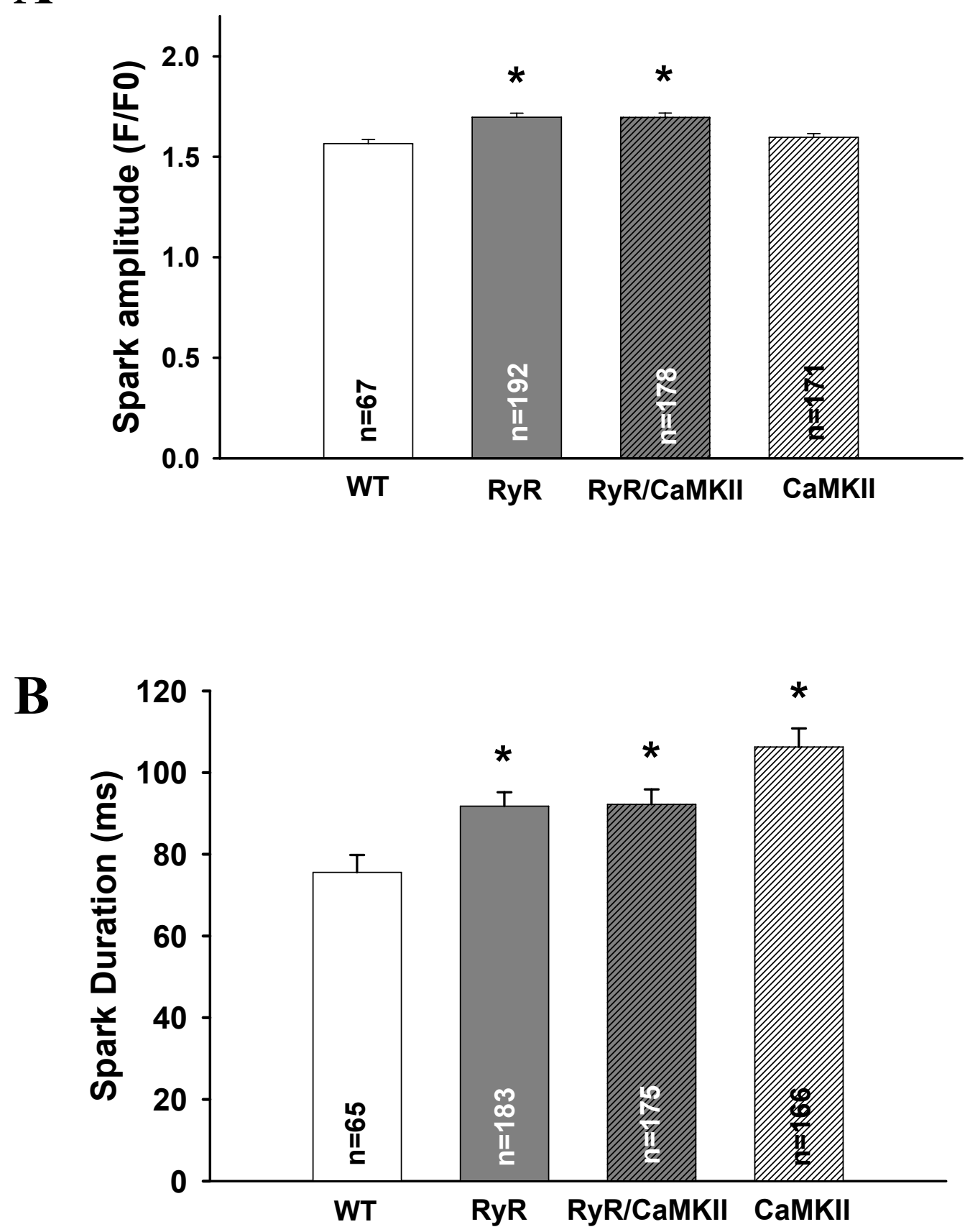

Figure 29. $\mathrm{Ca}^{2+}$ spark characteristics. (A) Mean data for the $\mathrm{Ca}^{2+}$ spark amplitude $\left(\mathrm{F} / \mathrm{F}_{0}\right)$ representing increased amplitude in $\mathrm{RyR} 2^{\mathrm{R} 4496 \mathrm{C}+/}$, CaMKII $\delta_{\mathrm{C}} / \mathrm{RyR} 2^{\mathrm{R} 4496 \mathrm{C}}$ myocytes, but not in CaMKII $\delta_{\mathrm{C}}$ versus WT. ${ }^{*} \mathrm{P}<0.05$ versus WT. (B) Mean data of $\mathrm{Ca}^{2+}$ spark duration showing larger duration in RyR2 $2^{\mathrm{R} 4496 \mathrm{C}+/}$, CaMKII $\delta_{\mathrm{C}} / \mathrm{RyR}^{\mathrm{R} 4496 \mathrm{C}}$ and CaMKII $\delta_{\mathrm{C}}$ myocytes compare to WT, which suggests longer RyR2 openings. ${ }^{*} \mathrm{P}<0.05$ versus WT. 


\subsection{Increased arrhythmogenic events in $\mathrm{RyR2}^{\mathrm{R4496} \mathrm{C}+/}$, CaMKII $\delta_{C} /$ RyR2 $^{\text {R4496C }}$ and CaMKII $\delta_{C}$ mice}

To test whether RyR2 $2^{\mathrm{R} 4496 \mathrm{C}+/}$, CaMKII $\delta_{\mathrm{C}} / \mathrm{RyR} 2^{\mathrm{R} 4496 \mathrm{C}}$ and CaMKII $\delta_{\mathrm{C}}$ mice have increased cellular arrhythmias at baseline, the incidence of proarrhythmogenic events (nonstimulated events) in electrically paced isolated ventricular myocytes from RyR2 $2^{\mathrm{R} 4496 \mathrm{C}+/-}$ knock-in, CaMKII $\delta_{\mathrm{C}} / \mathrm{RyR} 2^{\mathrm{R} 4496 \mathrm{C}}$ double mutant, and CaMKII $\delta_{\mathrm{C}}$ transgenic mouse hearts relative to WT was assessed. These proarrhythmogenic events were observed during the measurement of cell shortening and $\mathrm{Ca}^{2+}$ transients using epifluorescence experiments when stimulation was paused (Fig. 30A) as well as during steady-state stimulation at $1 \mathrm{~Hz}$ (Fig. 30B). A previously published non-stimulated events classification differentiated between early-spike non-stimulated events and late-spike non-stimulated events. The latespike non-stimulated events occur as single events or can sustain if they outlast electric field stimulation (Wu et al., 2002). In every mouse genotype tested in this study all classes of non-stimulated events occurred. However, cellular arrhythmias were significantly more common in RyR2 $2^{\mathrm{R} 4496 \mathrm{C}+/}$, CaMKIII $\delta_{\mathrm{C}} / \mathrm{RyR} 2^{\mathrm{R} 4496 \mathrm{C}}$ and CaMKII $\delta_{\mathrm{C}}$ myocytes as compared to WT control myocytes, which might indicate their predisposition to triggered arrhythmias in vivo. Non-stimulated events were present in 27 out 96 myocytes in RyR2 $2^{\mathrm{R} 4496 \mathrm{C}+/}$, in 31 out 105 in $\mathrm{CaMKII} \delta_{\mathrm{C}} / \mathrm{RyR}^{\mathrm{R} 4496 \mathrm{C}}$, and in 18 out 77 in CaMKII $\delta_{\mathrm{C}}$, whereas WT myocytes showed non-stimulated events only in 10 out $136(\mathrm{P}<0.05)$. Compared to WT myocytes, which showed mainly early-spike non-stimulated events, RyR2 ${ }^{\mathrm{R} 4496 \mathrm{C}+/}$, CaMKIII $\delta_{C} / \mathrm{RyR}^{\mathrm{R} 4496 \mathrm{C}}$ and $\mathrm{CaMKII} \delta_{\mathrm{C}}$ myocytes exhibited more frequently cellular arrhythmias characterized by sustained late-spike non-stimulated events. Most importantly, arrhythmias were observed in isolated myocytes from $\sim 50 \%$ of RyR2 ${ }^{\mathrm{R} 4496 \mathrm{C}+/}$, from $\sim 80 \%$ of $\mathrm{CaMKII} \delta_{\mathrm{C}} / \mathrm{RyR}^{\mathrm{R} 4496 \mathrm{C}}$ but only from $\sim 30 \%$ of CaMKIII $\delta_{\mathrm{C}}$ mice, as compared to less than $10 \%$ in WT control (Fig. 30C). Therefore, enhanced cellular arrhythmias at baseline in $\mathrm{CaMKII}_{\mathrm{C}} / \mathrm{RyR}^{\mathrm{R} 4496 \mathrm{C}}$ mice might be due to an increased $\mathrm{SR} \mathrm{Ca}^{2+}$ leak. This could explain the high mortality in CaMKII $\delta_{\mathrm{C}} / \mathrm{RyR} 2^{\mathrm{R} 4496 \mathrm{C}}$ double mutant mice as compared to WT and RyR2 $2^{\mathrm{R} 4496 \mathrm{C}+/-}$ mice and even when compared to CaMKIII $\delta_{\mathrm{C}}$ mice. 
A

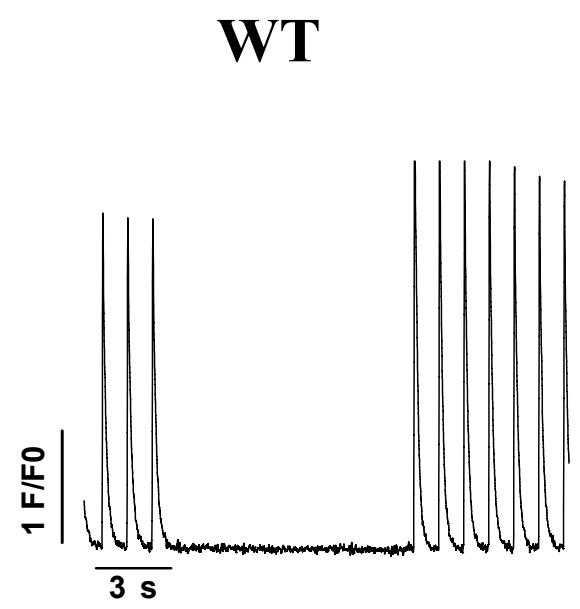

RyR

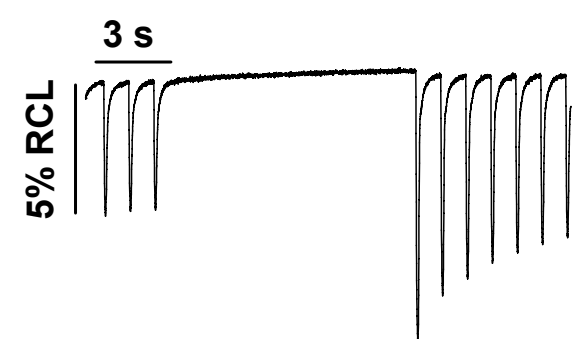

RyR/CaMKII
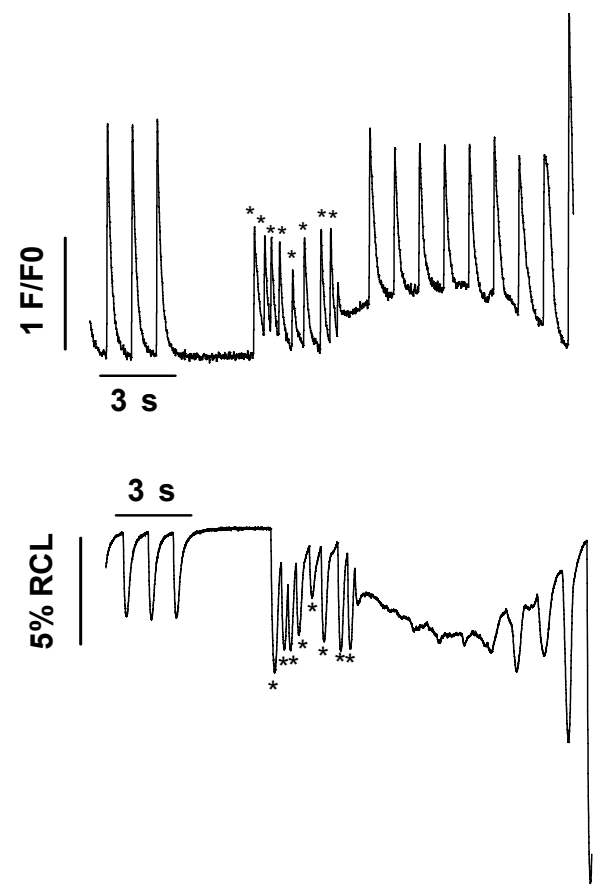
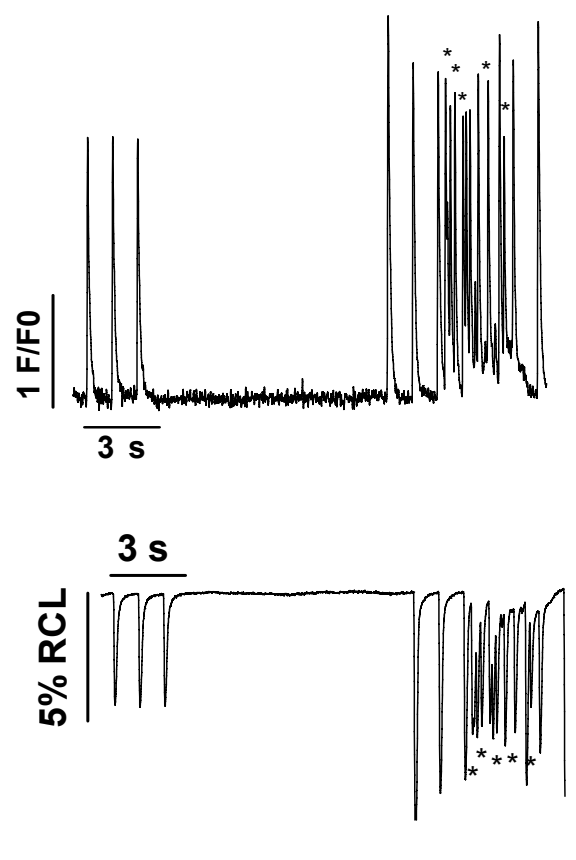

CaMKII
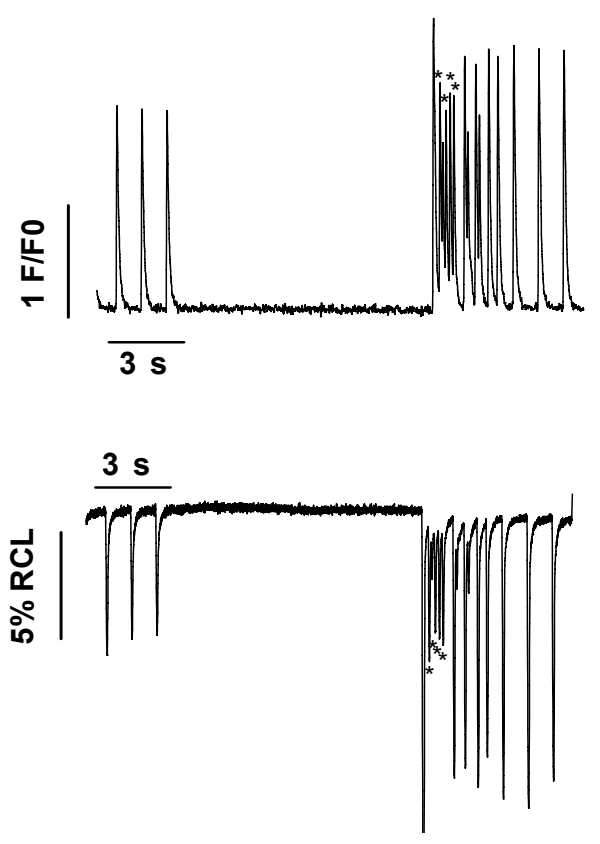
WT

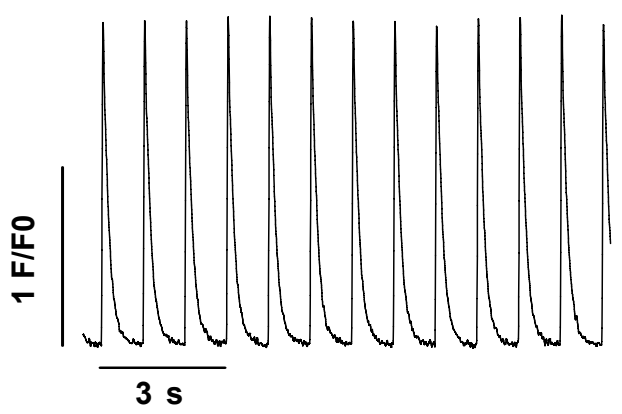

RyR/CaMKII

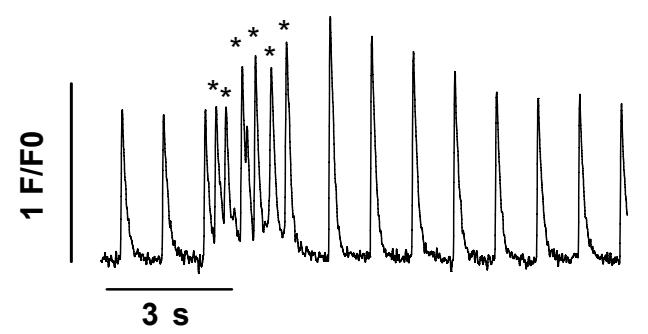

RyR

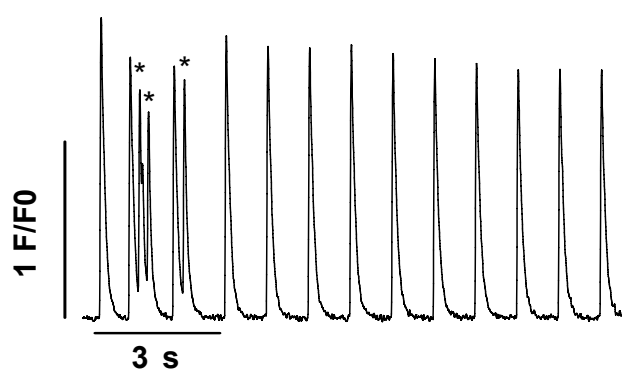

CaMKII

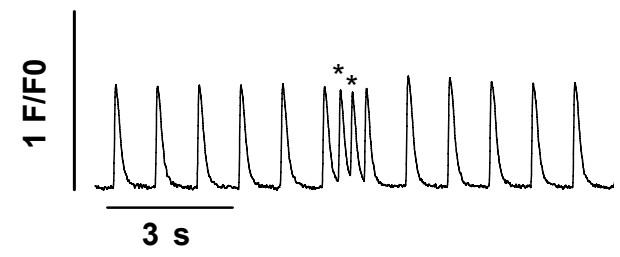

C

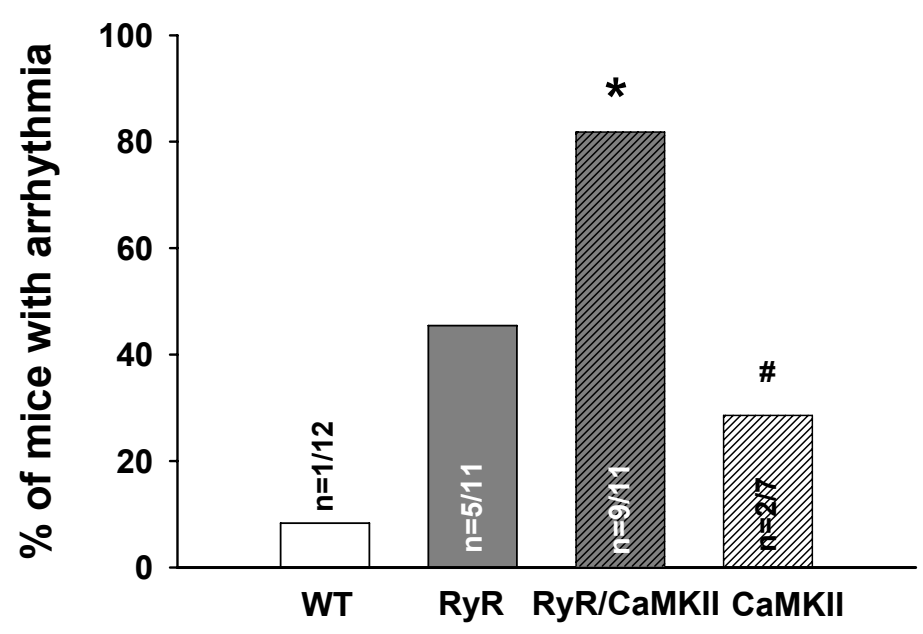

Figure 30. Cellular arrhythmias recorded in electrically paced isolated ventricular myocytes from RyR2 ${ }^{\mathrm{R} 4496 \mathrm{C}+/}$, CaMKII $\delta_{\mathrm{C}} / \mathrm{RyR2}^{\mathrm{R} 4496 \mathrm{C}}$ and CaMKII $\delta_{\mathrm{C}}$ mouse hearts. (A) Original $\mathrm{Ca}^{2+}$ and shortening traces showing spontaneous cellular arrhythmias (depicted by *) in myocytes isolated from RyR2 ${ }^{\mathrm{R} 4496 \mathrm{C}+/}$, CaMKII $\delta_{\mathrm{C}} / \mathrm{RyR}^{\mathrm{R} 4496 \mathrm{C}}$ and $\mathrm{CaMKII} \delta_{\mathrm{C}}$ mice during $10 \mathrm{sec}$ rest but no arrhythmias in WT. (B) Original $\mathrm{Ca}^{2+}$ traces with increased non-stimulated events during $1 \mathrm{~Hz}$ stimulation. (C) The number of mice with arrhythmias was significantly higher in CaMKII $\delta_{\mathrm{C}} / \mathrm{RyR}^{\mathrm{R} 4496 \mathrm{C}}$ versus WT. $* \mathrm{P}<0.05$ versus WT. \# $\mathrm{P}<0.05$ versus $\mathrm{CaMKII} \delta_{\mathrm{C}} / \mathrm{RyR}^{\mathrm{R} 4496 \mathrm{C}}$. 


\section{Discussion}

\subsection{CaMKII $\delta_{\mathrm{C}}$ associates with and phosphorylates cardiac $\mathrm{Na}^{+}$channels}

The voltage-gated $\mathrm{Na}^{+}$channels composed of pore-forming $\alpha$ and auxiliary $\beta$ subunits are responsible for the rising phase of the action potential in cardiac muscle. Action potentials are fundamentally required to initiate myocyte shortening and therefore cardiac contractions. Cardiac function depends on the amplitude, timing and voltage dependence of $\mathrm{Na}^{+}$current through $\mathrm{Na}^{+}$channels. Altered $\mathrm{Na}^{+}$channel gating and changes in intracellular sodium homeostasis play an important role in the pathophysiology of heart failure. Tiny alterations in channel function could result in altered ion fluxes, which may have a great impact on the action potential characteristics and E-C coupling. So far, it was only known that cardiac $\mathrm{Na}^{+}$channels are regulated through phosphorylation by $\mathrm{PKC}$ and PKA.

The present study shows for the first time that CaMKII $\delta_{\mathrm{C}}$ associates with and phosphorylates cardiac $\mathrm{Na}^{+}$channels. The localization of $\mathrm{Na}^{+}$channel $\alpha$ subunits in isolated adult mouse and rabbit ventricular myocytes was also determined. The isoform Nav1.5 (SCN5A) of the $\alpha$ subunit is the predominant isoform in the heart. However, the brain-type isoforms Nav1.1, Nav1.3, and Nav1.6 were shown to be expressed in ventricular myocytes having distinct subcellular localization and function (Maier et al 2002). The immunofluorescence experiments presented here using labeled Nav1.5 channels confirmed the specific localization of this subtype of sodium channels within the transverse tubular system in rabbit as well as mouse myocytes. This result is in contrast to data published by Sebastian Maier and colleagues (Maier et al 2002; Maier et al 2004) who localized the Nav1.5 only in intercalated disks but not in transverse tubules of adult isolated mouse ventricular cells. However, Nav1.5 subcellular localization in transverse tubules and intercalated discs as shown here is in agreement with a report by Mohler and colleagues (Mohler et al., 2004) who studied Nav1.5 in isolated cardiomyocytes of adult rat. In addition, other authors also confirmed that Nav1.5 is localized only in transverse tubules (Haufe et al., 2005; Dominguez et al., 2008). The use of distinct sources of antibodies and technical procedures might underlie such differences, although such controversies remain to be further dissected.

Differentially localized sodium channels may have different physiological roles. $\mathrm{Na}^{+}$ channels in intercalated disks are involved primarily in initiation and propagation of the cardiac action potential from cell to cell. In contrast, $\mathrm{Na}^{+}$channels in transverse tubules 
may function in coordinating and synchronizing the conduction of the action potential from the cell surface of the myocyte into the interior via the transverse tubules (Maier et al., 2002).

The immunofluorescent studies presented here using double labeling of CaMKII $\delta_{\mathrm{C}}$ and Nav1.5 channels revealed that cytoplasmic isoform of CaMKII $\delta_{\mathrm{C}}$ co-localized with cardiac $\mathrm{Na}^{+}$channels in both mouse and rabbit ventricular myocytes. Further coimmunoprecipitation experiments confirmed that CaMKII $\delta_{\mathrm{C}}$ associates with $\mathrm{Na}^{+}$channels in both mouse and rabbit tissue.

It is known that protein kinases PKA and PKC can phosphorylate and thereby regulate cardiac $\mathrm{Na}^{+}$channels. However, PKA and PKC modulate cardiac $\mathrm{Na}^{+}$channels differently. PKA-dependent phosphorylation at Ser-526 and Ser-529 in the I-II cytoplasmic linker in response to increased intracellular levels of cAMP increases whole-cell conductance without altering channel gating. Single channel experiments revealed that the increase in whole-cell conductance resulted from an increased number of functional $\mathrm{Na}^{+}$channels, possibly by altered channel trafficking (Murphy et al., 1996; Fronwieser et al., 1997). Also, some authors found a cAMP-dependent enhancement of $\mathrm{Na}^{+}$channel steady-state inactivation (Ono et al., 1989). PKC-dependent phosphorylation at Ser 1505 in the III-IV cytoplasmic linker reduces maximal conductance and enhances steady-state inactivation ( $\mathrm{Qu}$ et al., 1996). In the present study it is shown that exogenous CaMKII can phosphorylate $\mathrm{Na}^{+}$channels and, importantly, that endogenous CaMKII in rabbit myocytes can phosphorylate the $\mathrm{Na}^{+}$channel at an intracellular $\mathrm{Ca}^{2+}$ concentration that is physiologically relevant. In addition, when CaMKII was overexpressed in these myocytes, the $\mathrm{Na}^{+}$channel was more phosphorylated even at diastolic $\mathrm{Ca}^{2+}$ level $(50 \mathrm{nM})$. These results suggest that CaMKII association and thereby phosphorylation of $\mathrm{Na}^{+}$channels is physiologically relevant and may also regulate the channels.

Deschênes and colleagues (Deschênes et al., 2002) were the first to investigate CaMKdependent regulation of cardiac $\mathrm{Na}^{+}$channels expressed in human embryonic kidney (HEK 293) cells. They showed that the nonselective CaMK inhibitor KN-93 induces $\mathrm{Na}^{+}$current decay consistent with an inhibition of fast inactivation and shifted steady-state inactivation in the depolarizing direction.

Wagner and colleagues (Wagner et al., 2006) assessed the role of CaMKII $\delta_{\mathrm{C}}$ on $\mathrm{Na}^{+}$ channel function using 2 models: CaMKII $\delta_{\mathrm{C}}$ TG mice, which develop HF, as well as acute CaMKIII $\delta_{\mathrm{C}}$ overexpression in rabbit myocytes. They measured steady-state inactivation and activation of $\mathrm{Na}^{+}$channels and found that CaMKII does not alter activation of the channel, 
but dramatically alters its inactivation. Several types of $\mathrm{Na}^{+}$current inactivation were distinguished:

1) "fast" inactivation occurring over $2-10 \mathrm{~ms}$ which recovers rapidly at negative membrane potential; 2) "intermediate" inactivation occurring over hundreds of milliseconds after fast inactivation recovering more slowly; 3) "slow" inactivation occurring over tens of seconds (Bers, 2001). These different inactivation modes can all influence $\mathrm{Na}^{+}$channel steady-state inactivation, action potential duration, and $\mathrm{Na}^{+}$flux balance. Transgenic CaMKII $\delta_{\mathrm{C}}$ overexpression enhances accumulation of intermediate inactivation as shown by Wagner et al. Physiologically, only a small fraction of $\mathrm{Na}^{+}$channels undergo intermediate inactivation and reduce the amount of channels available for the second excitation. Thus, CaMKII $\delta_{\mathrm{C}}$ may increase the fraction of channels that can enter intermediate inactivation consistent with a reduced channel function (Wagner et al., 2006). Enhanced intermediate inactivation has been implicated in Brugada syndrome. The syndrome is associated with lifethreatening ventricular tachyarrhythmias (Wang et al., 2000) and has been shown to result in strikingly similar alteration in gating as observed upon increased CaMKII $\delta_{\mathrm{C}}$ activity (Wagner et al., 2006).

In contrast to intermediate inactivation, for which no structural correlate has been found yet, the cytoplasmic linker between domains III and IV and $\mathrm{C}$ terminus of the $\mathrm{Na}^{+}$channel $\alpha$-subunit has been proposed to underlie fast inactivation. CaMKII $\delta_{\mathrm{C}}$ overexpression slowed fast inactivation increasing the amount of $\mathrm{Na}^{+}$influx leading to enhanced intracellular $\mathrm{Na}^{+}$concentration (Wagner et al., 2006). Mutations in the III and IV cytoplasmic linker and $\mathrm{C}$ terminus of the $\mathrm{Na}^{+}$channel slow the inactivation process leading to LQT3 (Bennett et al., 1995). Impaired fast $\mathrm{Na}^{+}$channel inactivation mimics the functional defects of mutant $\mathrm{Na}^{+}$channels associated with LQT3 (Wagner et al., 2006). Slowed $\mathrm{Na}^{+}$current inactivation could prolong action potential duration, leading to early afterdepolarization or LQT3-like propensity for arrhythmias as well as may elevate intracellular $\mathrm{Na}^{+}$concentration causing $\mathrm{Ca}^{2+}$ overload-induced spontaneous sarcoplasmic reticulum $\mathrm{Ca}^{2+}$ release and transient inward current via $\mathrm{Na}^{+} / \mathrm{Ca}^{2+}$ exchange, which lead to delayed afterdepolarizations (Bers, 2001).

Thus, CaMKII $\delta_{\mathrm{C}}$ enhances intermediate inactivation, while at the same time impairing fast inactivation and enhancing persistent $\mathrm{Na}^{+}$current (Wagner et al., 2006). Similar changes in $\mathrm{Na}^{+}$channel gating were shown for a human mutant $\mathrm{Na}^{+}$channel (Asp insertion at 1795 in the C terminus), which shows simultaneous LQT3-like and Brugada-like phenotypes (Veldkamp et al., 2000). At slow heart rates, mutant $1795 \mathrm{ins} \mathrm{D} \mathrm{Na}^{+}$channel impaired fast 
inactivation and increased $\mathrm{Na}^{+}$current influx favoring action potential prolongation, which is consistent with LQT3 syndrome (Bennett et al., 1995). However, at higher heart rates, 1795insD induces reduced $\mathrm{Na}^{+}$channel availability and action potential shortening underlying Brugada syndrome. Therefore, it is conceivable that increased CaMKII $\delta_{\mathrm{C}}$ activity in heart failure may alter $\mathrm{Na}^{+}$channel gating, thereby generating the substrate for arrhythmias. CaMKIII $\delta_{\mathrm{C}}$ TG mice indeed showed an increased propensity for arrhythmias in vivo (Wagner et al., 2006). The QRS duration in CaMKII $\delta_{\mathrm{C}} \mathrm{TG}$ mice was prolonged indicating slowed intraventricular conduction, which is proarrhythmic in Brugada syndrome. Repolarization was disturbed in TG mice, which favors arrhythmias in LQT3 patients. Action potential duration was prolonged which could contribute to EAD and LQT3-like arrhythmias. The resulting increased intracellular $\mathrm{Na}^{+}$concentration could also enhance SR $\mathrm{Ca}^{2+}$ content via NCX, leading to spontaneous SR $\mathrm{Ca}^{2+}$ release and DAD. Thus, the CaMKII $\delta_{\mathrm{C}^{-}}$-dependent $\mathrm{Na}^{+}$channel modulation can be an acquired form of combined LQT3 and Brugada syndrome, which may contribute to arrhythmias when CaMKII activity is increased as in HF.

In the present study, acute $\mathrm{CaMKII} \delta_{\mathrm{C}}$ overexpression in rabbit cardiomyocytes did not alter protein expression levels. This suggests that $\mathrm{CaMKII} \delta_{\mathrm{C}}$-dependent $\mathrm{Na}^{+}$channel regulation may not involve primary effects on $\mathrm{Na}^{+}$channel expression. However, CaMKII $\delta_{\mathrm{C}} \mathrm{TG}$ mice exhibiting heart failure showed significantly more $\mathrm{Na}^{+}$channel expression, which could be a consequence of the heart failure phenotype.

In summary, it was shown for the first time that CaMKII associates and phosphorylates $\mathrm{Na}^{+}$channels. In the face of an increased propensity for arrhythmias in heart failure and increased CaMKII expression levels and activity, it is possible that regulation of $\mathrm{Na}^{+}$ channel function by CaMKII may contribute to these adverse effects.

\subsection{Functional characterization of $\mathrm{RyR2}^{\mathrm{R} 4496 \mathrm{C}+/-}$ mice harboring a human CPVT mutation}

Catecholaminergic polymorphic ventricular tachycardia is a disease caused by mutations in the RyR2 gene encoding the cardiac ryanodine receptor characterized by adrenergically mediated bidirectional and polymorphic VT and ventricular fibrillation (Leenhardt et al., 1995; Priori et al., 2002). Interestingly, patients with CPVT apparently have functionally normal hearts (Leenhardt et al., 1995; Laitinen et al., 2004) and the mouse model harboring 
the R4496C mutation in RyR2 shows neither macroscopic alteration of the heart nor any tissue abnormalities (Cerrone et al., 2003). The clinical phenotype of CPVT patients consists of ventricular arrhythmias inducible with exercise stress testing (Leenhardt et al., 1995; Priori et al., 2002). The presence of the R4496C mutation predisposed the murine heart to the development of ventricular tachycardia and fibrillation after administration of caffeine and adrenergic agonists. It is remarkable that ventricular tachycardia in $\mathrm{RyR} 2^{\mathrm{R} 4496 \mathrm{C}+/}$ mice had the typical bidirectional morphology that is considered the most distinguishing characteristic of CPVT patients. The mutation that was identified in CPVT family is located in the $\mathrm{C}$ terminal portion of the channel and leads to the replacement of arginine at the position 4497 with a cysteine (Cerrone et al., 2003). Because this mutation was associated with a highly malignant phenotype it has been selected by several groups for their in vitro studies. The R4496C mutation has been expressed and investigated in a heterologous system. Jiang and colleagues (Jiang et al., 2002) first studied the mouse RyR2 mutant R4496C corresponding to the R4497C human mutation by expression in HEK 293 cells and single-channel analysis showed that this mutation enhanced the basal channel activity and the propensity for spontaneous $\mathrm{Ca}^{2+}$ release. Recently, this group confirmed their results and suggested that the R4496C mutation increases the channel sensitivity to activation by luminal $\mathrm{Ca}^{2+}$ (Jiang et al., 2004). George and colleagues (George et al., 2003) investigated the same mutation by expression in a cardiac muscle cell line (HL-1 cardiomyocytes) and demonstrated that the R4496C mutant shows no enhancement of basal activity; however, intracellular $\mathrm{Ca}^{2+}$ release was significantly augmented in cells expressing mutant RyR2 after addition of caffeine agonist or beta adrenergic stimulation. Nonetheless, all of the investigators agree that the abnormal $\mathrm{Ca}^{2+}$ handling observed in R4496C RyR2 is likely to promote the development of DAD and triggered arrhythmias. Expression studies assessing mutant RyR2 function were carried out in a variety of models which may explain the controversial findings. It is likely, however, that appropriate regulation of RyR2 requires the precise interaction of a multitude of accessory proteins, which may be absent in the heterologous systems, so the analysis in native cardiac myocytes is important to clarify the mechanism by which the mutation leads to cardiac arrhythmias. In order to investigate whether RyR $2^{\mathrm{R} 4496 \mathrm{C}+/-}$ myocytes develop DAD in the absence of adrenergic stimulation, isolated cells from the hearts of knock-in mice were patch-clamped and action potentials recorded. The study showed that DAD and triggered activity were already present in unstimulated RyR2 $2^{\mathrm{R} 4496 \mathrm{C}+/}$ myocytes (Liu et al., 2006). 
In the present study, functional characterization of mice harboring a human RyR2 mutation (R4496C) associated with CPVT was performed using echocardiography (to assess in vivo cardiac function) as well as measurements of intracellular $\mathrm{Ca}^{2+}$ homeostasis (to evaluate global E-C coupling in isolated cardiomyocytes). The isolated RyR2 ${ }^{\mathrm{R} 4496 \mathrm{C}+/-}$ mouse hearts showed no signs of hypertrophy and analysis of cardiomyocytes gave normal values. Echocardiographic measurements confirmed that RyR2 ${ }^{\mathrm{R} 4496 \mathrm{C}+/}$ knock-in mice have structurally and functionally normal hearts. Experiments to assess E-C coupling were performed in isolated single ventricular cardiac myocytes. In the heart, E-C coupling is the central mechanism by which electrical activation is translated into cardiac contraction. Cardiac contractions are directly governed by free cytosolic $\mathrm{Ca}^{2+}$. Therefore, precise regulation of intracellular $\mathrm{Ca}^{2+}$ is critical for normal cardiac function. In detail, E-C coupling proceeds in a few steps: during depolarization small amounts of $\mathrm{Ca}^{2+}$ enters the cell through voltage-dependent L-type $\mathrm{Ca}^{2+}$ channels. This inward $\mathrm{Ca}^{2+}$ current activates RyR2s to release further $\mathrm{Ca}^{2+}$ from the SR into the cytosol. The rise in cytosolic $\mathrm{Ca}^{2+}$ activates the myofilaments and triggers contraction. The main mechanisms for $\mathrm{Ca}^{2+}$ elimination from the cytosol are pumping of $\mathrm{Ca}^{2+}$ back into SR by SERCA2a and the extrusion of $\mathrm{Ca}^{2+}$ out of myocytes by NCX (Bers, 2002). The investigation of $\mathrm{Ca}^{2+}$ transients and single cell shortening at several pacing rates in the present study revealed that the $\mathrm{Ca}^{2+}$ transient amplitude and fractional shortening in $\mathrm{RyR} 2^{\mathrm{R} 4496 \mathrm{C}+/-}$ knock-in and WT myocytes were similar, which is consistent with the normal heart function in $\mathrm{RyR} 2^{\mathrm{R} 4496 \mathrm{C}+/}$ mice under physiological conditions. Moreover, at these pacing rates, the $\mathrm{Ca}^{2+}$ transient decay time and half-relaxation time of fractional shortening were also similar, suggesting a normal function of the SERCA2a activity. The SERCA2a and PLB protein expression levels were increased in homogenates prepared from RyR2 $2^{\mathrm{R} 4496 \mathrm{C}+/-}$ mouse hearts. However, the ratio of SERCA2a/PLB was unchanged, indicating unaltered $\mathrm{SR} \mathrm{Ca}^{2+}$ uptake function, that is consistent with the functional data assessed. NCX function and expression were also unaltered.

In addition to stimulating $\mathrm{Ca}^{2+}$ release during normal E-C coupling, $\mathrm{Ca}^{2+}$ release from the $\mathrm{SR}\left(\mathrm{Ca}^{2+}\right.$ sparks) can also occur spontaneously as a result of spontaneous opening of the RyR2 channels (Cheng et al., 1993). In cardiomyocytes isolated from RyR2 ${ }^{\mathrm{R} 4496 \mathrm{C}+/-}$ knockin mice, diastolic $\mathrm{Ca}^{2+}$ leak from the SR revealed a 2-fold increased $\mathrm{Ca}^{2+}$ spark frequency with high amplitudes and longer durations, suggesting increased open probability of RyR2 in mutant mice. The increased activity of the RyR2 could depend on the amount of $\mathrm{Ca}^{2+}$ stored in the SR, however, the SR $\mathrm{Ca}^{2+}$ load in $\mathrm{RyR} 2^{\mathrm{R} 4496 \mathrm{C}+/-}$ knock-in mice was not 
different from control. Thus the higher $\mathrm{Ca}^{2+}$ sparks occurrence in RyR2 ${ }^{\mathrm{R} 4496 \mathrm{C}+/-}$ myocytes is not due to either a higher level of $\mathrm{Ca}^{2+}$ stored in the SR or alteration of calsequestrin level. The increased CaSpF in mutant RyR2 $2^{\mathrm{R} 4496 \mathrm{C}+/}$ mice is probably caused by "leaky" ryanodine receptor because of the mutation itself. This might also explain the apparent E-C coupling enhancement (higher fractional SR $\mathrm{Ca}^{2+}$ release) found in the present study. This enhanced cardiac diastolic $\mathrm{Ca}^{2+}$ leak may lead to the generation of DAD found by Liu and colleagues (Liu et al., 2006) resulting in arrhythmias (Pogwizd et al., 2001; Shannon et al., 2003). In detail, the directed leak of SR $\mathrm{Ca}^{2+}$ toward the NCX may lead to spontaneous depolarizations of the sarcolemma (Pogwizd et al., 2001). This may contribute to electrical instability, early or delayed afterdepolarizations and triggered arrhythmias (Lehnart et al., 2005; Wehrens et al.; 2003). In electrically paced isolated myocytes from RyR2 $2^{\mathrm{R} 4496 \mathrm{C}+/}$ mice, an increased amount of cellular arrhythmias at baseline was found in the present study, which is likely a consequence of the increased diastolic SR $\mathrm{Ca}^{2+}$ leak.

In conclusion, the R4496C mutation in cardiac RyR2 leads to increased fractional SR Ca ${ }^{2+}$ release during systole as well as enhanced diastolic $\mathrm{Ca}^{2+}$ leak from the SR, indicating increased RyR2 open probability and leading to a higher propensity for the development of DAD and triggered arrhythmias.

\subsection{Overexpression of CaMKII $\delta_{C}$ in mouse hearts bearing the R4496C mutation leads to arrhythmias and increased mortality}

CaMKII is involved in the modulation of cellular $\mathrm{Ca}^{2+}$ regulation, including E-C coupling and has been implicated in the development of heart failure (Maier and Bers, 2002; Braun and Schulman, 1995). Transgenic mice that overexpress CaMKII $\delta_{\mathrm{C}}$ show a reduction in twitch shortening, $\mathrm{Ca}^{2+}$ transient amplitude, SR $\mathrm{Ca}^{2+}$ content, as well as in SERCA2a and PLB expression. In contrast, the frequency of $\mathrm{Ca}^{2+}$ sparks was greatly enhanced. There was also enhanced NCX function and expression (Maier et al., 2003). In the present study, transgenic overexpression of cytosolic CaMKII $\delta_{\mathrm{C}}$ in the RyR2 ${ }^{\mathrm{R} 4496 \mathrm{C}+/}$ knock-in mutant mouse causes cardiac hypertrophy, contractile dysfunction and altered myocyte $\mathrm{Ca}^{2+}$ handling similar to previously published work in CaMKII $\delta_{C}$ TG mice (Maier et al., 2003). Most interestingly, in contrast to CaMKII $\delta_{\mathrm{C}}$ transgenic mice with $80 \%$ survival after 10 weeks, CaMKIII $\delta_{\mathrm{C}} / \mathrm{RyR}^{\mathrm{R} 4496 \mathrm{C}}$ double mutant mice died spontaneously at the age of 8-14 
weeks with only $50 \%$ alive after 10 weeks. Possible reasons for these differences may be alterations in intracellular $\mathrm{Ca}^{2+}$ handling and/or cellular arrhythmias.

The most prominent and largely accepted disorder of E-C coupling in heart failure is decreased intracellular $\mathrm{Ca}^{2+}$ transients resulting from reduced SR $\mathrm{Ca}^{2+}$ load (Maier et al., 2003; Pieske et al., 1999) causing contractile dysfunction (Yano et al., 2005; Hasenfuss and Pieske, 2002). Reduction in SR $\mathrm{Ca}^{2+}$ reuptake via SERCA2a and increased SR Ca ${ }^{2+}$ leak through RyR2 are the main causative mechanisms for this phenomenon (Maier et al., 2003; Wehrens et al., 2004; Hasenfuss 1998; Ai et al., 2005; Marx et al., 2000). The CaMKII $\delta_{C} / \mathrm{RyR}^{\mathrm{R} 4496 \mathrm{C}}$ mice in the present study not only demonstrate this HF phenotype but also show similar changes with respect to intracellular $\mathrm{Ca}^{2+}$ handling.

As mentioned above, reuptake via SERCA2a is the dominating mechanism for cytosolic $\mathrm{Ca}^{2+}$ elimination in the healthy heart. SERCA2a protein expression and/or activity were found to be reduced in the failing human heart (Meyer et al., 1995; Schwinger et al., 1999). PLB in its unphosphorylated state is an endogenous inhibitor of SERCA2a (Brittsan and Kranias, 2000). CaMKII can phosphorylate PLB at Thr-17, which increases SERCA2a activity and thus improves contractile function (Zhang et al., 2003). In the present study SERCA2a protein expression was decreased whereas PLB protein levels were unchanged in $\mathrm{CaMKII} \delta_{\mathrm{C}} / \mathrm{RyR}^{\mathrm{R} 4496 \mathrm{C}}$ mice meaning that the ratio of SERCA2a relative to PLB is reduced. This indicates increased basal SERCA2a inhibition which may explain the prolonged relaxation kinetics. In addition, we detected similarly altered SERCA2a function with increased stimulation frequency in $\mathrm{CaMKII} \delta_{\mathrm{C}} / \mathrm{RyR} 2^{\mathrm{R} 4496 \mathrm{C}}$ and $\mathrm{CaMKII} \delta_{\mathrm{C}}$ as compared to WT mice. FDAR was prominent in all groups, with enhanced FDAR in double mutant and $\mathrm{CaMKII} \delta_{\mathrm{C}}$ transgenic mice (similar to the previous study with CaMKIII $\delta_{C}$ TG mice). FDAR is an important intrinsic mechanism that facilitates relaxation with increasing heart rate. FDAR is also reflected in the rate of $\mathrm{Ca}^{2+}$ decline and is attributable to enhanced SR $\mathrm{Ca}^{2+}$ uptake (Maier and Bers, 2002). Thus, although FDAR might be activated by enhanced SR $\mathrm{Ca}^{2+}$ uptake via PLB phosphorylation by CaMKIIdependent increased phosphorylation at Thr-17 of PLB (Ai et al., 2005; Zhang et al., 2003), it may be compensated by underphosphorylation of Ser-16 (Ai et al., 2005; Kohlhaas et al., 2006) as well as the reduction in SERCA2a and the decreased in SERCA2a/PLB ratio may lead to net decreased SR $\mathrm{Ca}^{2+}$ uptake. NCX is the other major mechanism for cytosolic $\mathrm{Ca}^{2+}$ elimination and the main transporter of $\mathrm{Ca}^{2+}$ from the cell (Bers, 2002). The driving force of the NCX is the trans-sarcolemmal electrochemical differences of $\mathrm{Na}^{+}$and $\mathrm{Ca}^{2+}$ and of the sarcolemmal membrane potential. In the "forward 
mode", the NCX eliminates one $\mathrm{Ca}^{2+}$ ion in exchange for three $\mathrm{Na}^{+}$ions, but as mentioned above, it can also operate in a "reverse mode", thus allowing $\mathrm{Ca}^{2+}$ to enter the cell. (Bers, 2001). Increased NCX expression and function are frequent findings in failing myocardium from several species including humans, but unchanged expression was also reported (Hasenfuss et al., 1999; Sipido et al., 2002). In the present study, no significant changes were found with respect to NCX protein expression in $\mathrm{CaMKII} \delta_{\mathrm{C}} / \mathrm{RyR} 2^{\mathrm{R} 4496 \mathrm{C}}$ mice. However its function, measured as exponential rate time-constant of $\mathrm{Ca}^{2+}$ decline during caffeine-induced $\mathrm{Ca}^{2+}$ transients, was slightly increased in CaMKII $\delta_{\mathrm{C}} / \mathrm{RyR} 2^{\mathrm{R} 4496 \mathrm{C}}$ and CaMKII $\delta_{\mathrm{C}}$ myocytes, indicating increased $\mathrm{Ca}^{2+}$ extrusion from the cell through $\mathrm{NCX}$.

In $\mathrm{CaMKII} \delta_{\mathrm{C}} / \mathrm{RyR}^{\mathrm{R} 4496 \mathrm{C}}$ mouse hearts $\mathrm{SR} \mathrm{Ca}^{2+}$ content was reduced to a similar extent as compared to CaMKII $\delta_{\mathrm{C}}$, which may result from the decreased $\mathrm{SR} \mathrm{Ca}^{2+}$ uptake or the enhanced $\mathrm{SR} \mathrm{Ca}^{2+}$ leak as it was shown for other heart failure models (Hasenfuss 1998; Shannon et al., 2003). Contractile function and twitch $\mathrm{Ca}^{2+}$ transient amplitude at the single cell level at all frequencies were significantly decreased in CaMKII $\delta_{C} / R y R 2^{R 4496 C}$ and CaMKII $\delta_{\mathrm{C}}$ mice compared to control. This observation can be explained by a decreased amount of SERCA2a protein level and function as well as the reduction in $\mathrm{SR}^{2+}$ content. This phenotype was also observed in studies using CaMKII $\delta_{\mathrm{C}}$ transgenic mice (Zhang et al., 2003; Maier et al., 2003) thus it correlates nicely to the in vivo data of the current study.

The fractional $\mathrm{Ca}^{2+}$ release, which provides an idea of how much $\mathrm{Ca}^{2+}$ is released at each twitch with respect to the total amount of $\mathrm{Ca}^{2+}$ stored within the SR, was significantly increased in CaMKII $\delta_{\mathrm{C}} / \mathrm{RyR} 2^{\mathrm{R} 4496 \mathrm{C}}$ and CaMKII $\delta_{\mathrm{C}}$ mice, although the lower SR $\mathrm{Ca}^{2+}$ content by itself would tend to greatly reduce fractional SR $\mathrm{Ca}^{2+}$ release. Thus, whereas SR $\mathrm{Ca}^{2+}$ content was reduced, the fraction of $\mathrm{SR} \mathrm{Ca}^{2+}$ released during a twitch was increased, suggesting altered RyR2 open probability in CaMKII $\delta_{C} / \mathrm{RyR}^{\mathrm{R} 4496 \mathrm{C}}$ double mutant and CaMKIII $\delta_{C}$ transgenic mice. This phenotype was also observed in previous studies using CaMKII $\delta_{C}$ transgenic mice (Maier et al., 2003; Zhang et al., 2003).

In $\mathrm{CaMKII} \delta_{\mathrm{C}} / \mathrm{RyR} 2^{\mathrm{R} 4496 \mathrm{C}}$ double mutant mice, $\mathrm{Ca}^{2+}$ sparks have increased frequency, higher amplitude and longer duration, demonstrating increased diastolic SR $\mathrm{Ca}^{2+}$ leak, despite reduced SR $\mathrm{Ca}^{2+}$ content and diastolic $\mathrm{Ca}^{2+}$ concentration, which actually should depress CaSpF (Cheng et al., 1993). In CaMKII $\delta_{\mathrm{C}}$ transgenic mice $\mathrm{Ca}^{2+}$ sparks have also increased frequency and duration but unchanged amplitude. One possible mechanism for this effect is an increased RyR2 opening at rest. RyR2 plays a central role in E-C coupling, it is therefore highly regulated. Recent studies have shown that CaMKII is associated with 
the RyR2 (Maier et al., 2003; Currie et al., 2004; Wehrens et al., 2004), it can phosphorylate the RyR2 (Currie et al., 2004; Maier et al., 2003; Rodriguez et al., 2003; Wehrens et al., 2004; Witcher et al., 1991) and that this CaMKII-dependent RyR2 phosphorylation increases $\mathrm{CaSpF}$ and duration in PLB-KO mouse myocytes (without increased SR Ca ${ }^{2+}$ content) (Guo et al., 2004; Guo et al., 2006). In contrast, when blocking CaMKII (using KN-93) $\mathrm{Ca}^{2+}$ spark frequency decreases dramatically (Maier et al., 2003). In HF there is CaMKII-dependent enhancement of diastolic $\mathrm{SR} \mathrm{Ca}^{2+}$ leak via RyR2 and

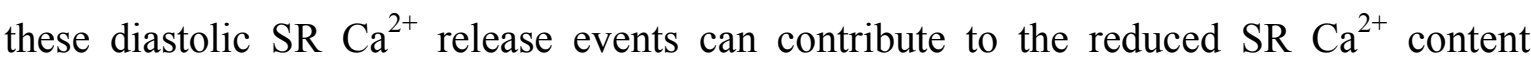
(Shannon et al., 2003; Guo et al., 2006). Previous studies with CaMKII $\delta_{\mathrm{C}}$ transgenic mice showed increased CaMKII association with RyR2, enhanced RyR2 phosphorylation, as well as increased fractional $\mathrm{SR} \mathrm{Ca}^{2+}$ release and resting $\mathrm{CaSpF}$ (despite lower $\mathrm{SR} \mathrm{Ca}^{2+}$ content and diastolic $\mathrm{Ca}^{2+}$ ) (Maier et al., 2003; Zhang et al., 2003). Acute CaMKII $\delta_{\mathrm{C}}$ overexpression in rabbit ventricular myocytes increased fractional $\mathrm{SR} \mathrm{Ca}^{2+}$ release and $\mathrm{CaSpF}$ due to phosphorylation of RyR2 (Kohlhaas et al., 2006). The results indicate that CaMKII can enhance RyR2 opening, both at rest (as SR $\mathrm{Ca}^{2+}$ sparks) and during E-C coupling (as fractional SR $\mathrm{Ca}^{2+}$ release). The CaMKII-dependent enhancement of diastolic $\mathrm{SR} \mathrm{Ca}^{2+}$ leak may also contribute to the activation of a transient inward NCX current that cause DAD and triggered arrhythmias. Indeed, in the present study cellular arrhythmias were observed more frequently in CaMKII $\delta_{C} / \mathrm{RyR}^{\mathrm{R} 4496 \mathrm{C}}$ mice versus $\mathrm{CaMKII} \delta_{\mathrm{C}}$ at baseline. In addition, this result was confirmed by data of Sedej and colleagues (Sedej et al., 2008) who showed significantly increased action potential durations in CaMKII $\delta_{C} / \mathrm{RyR}^{\mathrm{R} 4496 \mathrm{C}}$ and CaMKII $\delta_{\mathrm{C}}$ myocytes in contrast to WT using patch-clamp technique. Most importantly, DAD and spontaneous action potentials were clearly more often found in CaMKII $\delta_{\mathrm{C}} / \mathrm{RyR} 2^{\mathrm{R} 4496 \mathrm{C}}$ as compared to CaMKII $\delta_{\mathrm{C}}$ mouse myocytes, whereas WT showed almost no arrhythmias. DAD frequency was significantly increased in CaMKII $\delta_{C} / \mathrm{RyR}^{\mathrm{R} 4496 \mathrm{C}}$ versus CaMKII $\delta_{\mathrm{C}}$ myocytes. This possibly explains high mortality in double mutant mice. We propose that CaMKII-dependent enhancement of SR $\mathrm{Ca}^{2+}$ leak in $\mathrm{CaMKII} \delta_{\mathrm{C}} / \mathrm{RyR} 2^{\mathrm{R} 4496 \mathrm{C}}$ mice may increase the propensity for DAD and arrhythmias.

Here we also found that the expression level of calsequestrin was decreased in CaMKII $\delta_{C} / \mathrm{RyR}^{\mathrm{R} 4496 \mathrm{C}}$ mice. Calsequestrin is a high-capacity, low-affinity $\mathrm{Ca}^{2+}$-binding protein that represents a major $\mathrm{Ca}^{2+}$-reservoir element within the SR lumen (Jones et al., 1998). It has been reported that expression of genes encoding calsequestrin was repressed in both diseased human and rat hearts. This reduced expression might be viewed as an adaptive response to a reduced $\mathrm{Ca}^{2+}$ store within the sarcoplasmic reticulum (Zwadlo and 
Borlak, 2005; Borlak and Thum, 2003; Temsah et al., 2001) but it may very well contribute to increased RyR2 sensitivity in CaMKII $\delta_{\mathrm{C}} / \mathrm{RyR} 2^{\mathrm{R} 4496 \mathrm{C}}$ mice.

In conclusion, this study demonstrated that CaMKIII $\delta_{\mathrm{C}}$ overexpression in mouse hearts harboring the R4496C knock-in mutation in RyR2 leads to contractile dysfunction both in vivo and in vitro associated with defects in $\mathrm{Ca}^{2+}$ handling. The combination of the R4496C mutation with increased $\mathrm{CaMKII} \delta_{\mathrm{C}}$ activity provides an arrhythmogenic substrate. The strong increase in mortality in these mice may be explained by a combination of spontaneous fatal arrhythmias and impaired contractility. This is in contrast to $\mathrm{RyR} 2^{\mathrm{R} 4496 \mathrm{C}+/}$ mice which show CPVT without structural heart disease only in the presence of adrenergic stimulation. 


\section{References}

Ai X., Curran J.W., Shannon T.R., Bers D.M., Pogwizd S.M. $\mathrm{Ca}^{2+} /$ calmodulindependent protein kinase modulates cardiac ryanodine receptor phosphorylation and sarcoplasmic reticulum $\mathrm{Ca}^{2+}$ leak in heart failure. Circ Res. 97:1314-1322, 2005

Anderson M.E., Braun A.P., Schulman H., Premack B.A. Multifunctional $\mathrm{Ca} /$ calmodulin-dependent protein kinase mediates Ca-induced enhancement of the L-type Ca current in rabbit ventricular myocytes. Circ Res. 75:854-61, 1994

Anderson M.E., Braun A.P., Wu Y., Lu T., Schulman H., Sung R.J. KN-93, an inhibitor of multifunctional $\mathrm{Ca}^{2+} /$ calmodulin-dependent protein kinase, decreases early afterdepolarizations in rabbit heart. J Pharmacol Exp Ther. 287:996-1006, 1998

Bassani R.A. Mattiazzi A., Bers D.M. CaMKII is responsible for activity-dependent acceleration of relaxation in rat ventricular myocytes. Am J Physiol. 268:H703-12, 1995

Bennett P., Yazawa K., Makita N., George A. Molecular mechanism for an inherited cardiac arrhythmia. Nature. 376:683-685, 1995

Bers D.M. Cardiac excitation-contraction coupling. Nature. 415:198-205, 2002

Bers D.M. Excitation-contraction coupling and cardiac contractile force. 2nd ed. Kluwer. Dordrecht, Netherlands, 2001

Bers D.M., Guo T. Calcium signaling in cardiac ventricular myocytes. Ann N Y Acad Sci. 1047:86-98, 2005

Borlak J., Thum T. Hallmarks of ion channel gene expression in end-stage heart failure. FASEB J. 17:1592-1606, 2003

Braun A.P., Schulman H. The multifunctional calcium/calmodulin-dependent protein kinase: from form to function. Annu Rev Physiol. 57:417-445, 1995 
Brittsan A.G., Kranias E.G. Phospholamban and cardiac contractile function. J Mol Cell Cardiol. 32:2131-9, 2000

Brugada P., Brugada J. Right bundle branch block, persistent ST segment elevation and sudden cardiac death: a distinct clinical and electrocardiographic syndrome. A multicenter report. J Am Coll Cardiol. 20:1391-1396, 1992

Catterall W.A. From ionic currents to molecular mechanisms: the structure and function of voltage-gated sodium channels. Neuron. 26:13-25, 2000

Cerrone M., Colombi B., Santoro M., di Barletta M.R., Scelsi M., Villani L., Napolitano C., Priori S.G. Bidirectional ventricular tachycardia and fibrillation elicited in a knock-in mouse model carrier of a mutation in the cardiac ryanodine receptor. Circ Res. 96:e77-e82, 2005

Cheng H., Lederer W.J., Cannell M.B. Calcium sparks: elementary events underlying excitation-contraction coupling in heart muscle. Science. 262:740-744, 1993

Cheung W.Y. Calmodulin plays a pivotal role in cellular regulation. Science. 207:19-27, 1980

Colomer J.M., Mao L., Rockman H.A., Means A.R. Pressure overload selectively upregulates $\mathrm{Ca}^{2+} /$ calmodulin-dependent protein kinase II in vivo. Mol Endocrinol. 17:183-92, 2003

Colomer J.M., Means A.R. Chronic elevation of calmodulin in ventricles of transgenic mice increases the autonomous activity of calmodulin-dependent protein kinase II, which regulates atrial natriuretic factor gene expression. Mol Endocrinol. 14:1125-1136, 2000

Currie S., Loughrey C.M., Craig M.A., Smith G.L. Calcium/calmodulin-dependent protein kinase II $\delta$ associates with the ryanodine receptor complex and regulates channel function in rabbit heart. Biochem J. 377:357-66, 2004 
Davis B.A., Schwartz A., Samaha F.J., Kranias E.G. Regulation of cardiac sarcoplasmic reticulum calcium transport by calcium-calmodulin-dependent phosphorylation. J Biol Chem. 258:13587-91, 1983

DeSantiago J., Maier L.S., Bers D.M. Frequency-dependent acceleration of relaxation in the heart depends on CaMKII, but not phospholamban. J Mol Cell Cardiol. 34:975-84, 2002

Deschênes I., Neyroud N., DiSilvestre D., Marbán E., Yue D.T., Tomaselli G.F. Isoform-specific modulation of voltage-gated $\mathrm{Na}^{+}$channels by calmodulin. Circ Res. 90:49e-57, 2002

Dominguez J.N., Rosa A., Navarro F., Franco D., Aranega A.E. Tissue distribution and subcellular localization of the cardiac sodium channel during mouse heart development. Cardiovascular Res. 78:45-52, 2008

Dzhura I., Wu Y., Colbran R.J., Balser J.R., Anderson M.E. Calmodulin kinase determines calcium-dependent facilitation of L-type calcium channels. Nat Cell Biol. $2: 173-7,2000$

Edman C.F., Schulman H. Identification and characterization of $\delta_{\mathrm{B}}-\mathrm{CaM}$ kinase and $\delta_{\mathrm{C}^{-}}$ $\mathrm{CaM}$ kinase from rat heart, two new multifunctional $\mathrm{Ca}^{2+} /$ calmodulin-dependent protein kinase isoforms. Biochim Biophys Acta. 1221:89-101, 1994

Fill M., Copello J.A. Ryanodine receptor calcium release channels. Physiol Rev. 82:893922,2002

Fozzard H.A., Hanck D.A. Structure and function of voltage-dependent sodium channels: comparison of brain II and cardiac isoforms. Physiol Rev. 76:887-926, 1996

Frohnwieser B., Chen L., Schreibmayer W., Kallen R. Modulation of the human cardiac odium channel alpha-subunit by cAMP-dependent protein kinase and the responsible sequence domain. J Physiol. 498:309-318, 1997 
George C.H., Higgs G.V., Lai F.A. Ryanodine receptor mutations associated with stressinduced ventricular tachycardia mediate increased calcium release in stimulated cardiomyocytes. Circ Res. 93:531-540, 2003

Grueter C.E., Abiria S.A., Dzhura I., Wu Y., Ham A.J.L., Mohler P.J., Anderson M.E., Colbran R.J. L-type $\mathrm{Ca}^{2+}$ channel facilitation mediated by phosphorylation of the $\beta$ subunit by CaMKII. Mol Cell. 23:641-50, 2006

Guo T., Zhang T., Brown J.H., Bers D.M. Effects of CaMKII on cardiac Ca release channels in myocytes. Biophys J. 86:241a, 2004

Guo T., Zhang T., Mestril R., Bers D.M. Ca/calmodulin-dependent protein kinase II phosphorylation of ryanodine receptor does affect calcium sparks in mouse ventricular myocytes. Circ Res. 99:398-406, 2006

Hagemann D., Kuschel M., Kuramochi T., Zhu W., Cheng H., Xiao R.P. Frequencyencoding Thr17 phospholamban phosphorylation is independent of Ser16 phosphorylation in cardiac myocytes. J Biol Chem. 275:22532-6, 2000

Hain J., Onoue H., Mayrleitner M, Fleischer S., Schindler H. Phosphorylation modulates the function of the calcium release channel of sarcoplasmic reticulum from cardiac muscle. J Biol Chem. 270: 2074-81, 1995

Hasenfuss G., Pieske B. Calcium cycling in congestive heart failure. J Moll Cell Cardiol. 34:951-969, 2002

Hasenfuss G., Schillinger W., Lehnart S.E., Preuss M., Pieske B., Maier L.S., Prestle J., Minami K., Just H. Relationship between $\mathrm{Na}^{+}-\mathrm{Ca}^{2+}$ exchanger protein levels and diastolic function of failing human myocardium. Circulation. 99:641-8, 1999

Hasenfuss G. Alterations of calcium-regulatory proteins in heart failure. Cardiovasc Res. 37:279-289, 1998 
Haufe V., Camacho J.A., Dumaine R., Günther B., Bollensdorff C., Segond von Banchet G., Benndorf K., Zimmer T. Expression pattern of neuronal and skeletal muscle voltage-gated $\mathrm{Na}^{+}$channels in the developing mouse heart. J Physiol. 564:683-696, 2005

Hoch B., Meyer R., Hetzer R., Krause E.G., Karczewski P. Identification and expression of delta-isoforms of the multifunctional $\mathrm{Ca}^{2+} /$ calmodulin-dependent protein kinase in failing and nonfailing human myocardium. Circ Res. 84:713-21, 1999

Hook S.S., Means A.R. $\mathrm{Ca}^{2+} / \mathrm{CaM}-d e p e n d e n t$ kinases: from activation to function. Annu Rev Pharmacol Toxicol. 41:471-505, 2001

Hudmon A., Schulman H., Kim J., Maltez J.M., Tsien R.W., Pitt G.S. CaMKII tethers to L-type $\mathrm{Ca}^{2+}$ channels, establishing a local and dedicated integrator of $\mathrm{Ca}^{2+}$ signals for facilitation. J Cell Biol. 171:537-47, 2005

Isom L.L. Sodium channel beta subunits: anything but auxiliary. Neuroscientist. 7:42-54, 2001

Isom L.L., De Jongh K.S., Catterall W.A. Auxiliary subunits of voltage-gated ion channels. Neuron. 12:1183-1194, 1994

January C.T., Riddle J.M. Early afterdepolarizations: mechanism of induction and block. A role for L-type $\mathrm{Ca}^{2+}$ current. Circ Res. 64:977-90, 1989

Jiang D., Xiao B., Yang D., Wang R., Choi P., Zhang L., Cheng H., Chen S.R. RyR2 mutations linked to ventricular tachycardia and sudden death reduce the threshold for store-overload-induced $\mathrm{Ca}^{2+}$ release (SOICR). Proc Natl Acad Sci USA 101:13062-13067, 2004

Jiang D., Xiao B., Zhang L., Chen S.R. Enhanced basal activity of a cardiac $\mathrm{Ca}^{2+}$ release channel (ryanodine receptor) mutant associated with ventricular tachycardia and sudden death. Circ Res. 91:218-25, 2002 
Kirchhefer U., Schmitz W., Scholz H., Neumann J. Activity of cAMP-dependent protein kinase and $\mathrm{Ca}^{2+} /$ calmodulin-dependent protein kinase in failing and nonfailing human hearts. Cardiovasc Res. 42:254-61, 1999

Kohlhaas M., Zhang T., Seidler T., Zibrova D., Dybkova N., Steen A., Wagner S., Chen L., Brown J.H., Bers D.M., Maier L.M. Increased sarcoplasmic reticulum calcium leak but unaltered contractility by acute CaMKII overexpression in isolated rabbit cardiac myocytes. Circ Res. 98:235-44, 2006

Lai Y., Nairn A.C., Greengard P. Autophosphorylation reversibly regulates the $\mathrm{Ca} /$ calmodulin-dependent protein kinase II. Proc Natl Acad Sci. 83:4253-7; 1986

Laitinen P., Swan H., Piippo K., Viitasalo M., Toivonen L., Kontula K. Genes, exercise and sudden death: molecular basis of familial catecholaminergic polymorphic ventricular tachycardia. Ann Med. 36(Suppl1):81-6, 2004

Lee J.C., Edelman A.M. A protein activator of $\mathrm{Ca}^{2+} /$ calmodulin-dependent protein kinase Ia. J Biol Chem. 269:2158-2164, 1994

Leenhardt A., Lucet V., Denjoy I., Grau F., Ngoc D.D., Coumel P. Catecholaminergic polymorphic ventricular tachycardia in children. A 7-year follow-up of 21 patients. Circulation. 91:1512-1519, 1995

Lehnart S.E., Wehrens X.H., Marks A.R. Defective ryanodine receptor interdomain interactions may contribute to intracellular $\mathrm{Ca}^{2+}$ leak: a novel therapeutic target in heart failure. Circulation. 111:3342-3346, 2005

Li L., Satoh H., Ginsburg K.S., Bers D.M. The effect of Ca-calmodulin-dependent protein kinase II on cardiac excitation-contraction coupling in ferret ventricular myocytes. J Physiol. 501:17-32, 1997

Liu N., Colombi B., Memmi M., Zissimopoulos S., Rizzi N., Negri S., Imbriani M., Napolitano C., Lai F.A., Priori S.G. Arrhythmogenesis in catecholaminergic 
polymorphic ventricular tachycardia. Insights from a RyR2 R4496C knock-in mouse model. Circ Res. 99:292-298, 2006

Lokuta A.J., Rogers T.B., Lederer W.J., Valdivia H.H. Modulation of cardiac ryanodine receptors of swine and rabbit by a phosphorylation-dephosphorylation mechanism. J Physiol. 487:609-22, 1997

Lou L.L., Lloyd S.J., Shulman H. Activation of the multifunctional Ca/calmodulindependent protein kinase by autophosphorylation: ATP modulates production of an autonomous enzyme. Proc Natl Acad Sci. 83:9497-501, 1986

Lu T., Lee H-C., Kabat J.A., Shibata E.F. Modulation of rat cardiac sodium channel by the stimulatory G protein $\alpha$ subunit. J Physiol. 518:371-384, 1999

Maier L.S., Bers D.M. Calcium, calmodulin, and calcium-calmodulin kinase II: heartbeat to heartbeat and beyond. J Mol Cell Cardiol. 34:919-39, 2002

Maier L.S., Bers D.M. Role of $\mathrm{Ca}^{2+} /$ calmodulin-dependent protein kinase (CaMK) in excitation-contraction coupling in the heart. Cardiovasc Res. 73:631-640, 2007

Maier L.S., Zhang T., Chen L., DeSantiago J., Brown J.H., Bers D.M. Transgenic CaMKIII $\delta_{C}$ overexpression uniquely alters cardiac myocyte $\mathrm{Ca}^{2+}$ handling: reduced SR $\mathrm{Ca}^{2+}$ load and activated SR $\mathrm{Ca}^{2+}$ release. Circ Res. 92:904-11, 2003

Maier S.K.G., Westenbroek R.E., McCormic K.A., Curtis R., Scheuer T., Catterall W.A. Distinct subcellular localization of different sodium channel $\alpha$ and $\beta$ subunits in single ventricular myocytes from mouse heart. Circulation. 109:1421-1427, 2004

Maier S.K.G., Westenbroek R.E., Schenkman K.A., Feigl E.O., Scheuer T., Catterall W.A. An unexpected role for brain-type sodium channels in coupling of cell surface depolarization to contraction in the heart. PNAS. 99: 4073-8, 2002 
Marx S.O., Reiken S., Hisamatsu Y., Gaburjakova M., Gaburjakova J., Yang Y.M., Rosemblit N., Marks A.R. Phosphorylation-dependent regulation of ryanodine receptors: a novel role for leucine-isoleucine zippers. J Cell Biol. 154:699-708, 2001

Marx S.O., Reiken S., Hisamatsu Y., Jayaraman T., Burkhoff D., Rosemblit N., Marks A.R. PKA phosphorylation dissociates FKBP12.6 from the calcium release channel (ryanodine receptor): defective regulation in failing hearts. Cell. 101:365-376, 2000

Meissner G. Regulation of mammalian ryanodine receptors. Front Biosci. 7:d2072-d2080, 2002

Meyer M., Schillinger W., Pieske B., Holubarsch C., Heilmann C., Posival H., Kuwajima G., Mikoshib K., Just H., Hasenfuss G. Alterations of sarcoplasmic reticulum proteins in failing human dilated cardiomyopathy. Circulation. 92:778-784, 1995

Meyer T., Hanson P.I., Stryer L., Schulman H. Calmodulin trapping by calciumcalmodulin-dependent protein kinase II. Science. 256:1199-202, 1992

Mohler P.J., Rivolta I., Napolitano C., LeMaillet G., Lambert S., Priori S.G., Bennett V. Nav1.5 E1053K mutation causing Brugada syndrome blocks binding to ankyrin-G and expression of Nav1.5 on the surface of cardiomyocytes. PNAS. 101:17533-8, 2004

Motoike H.K., Liu H., Glaaser I.W., Yang A-S., Tateyama M., Kass R.S. The $\mathrm{Na}^{+}$ channel inactivation gate is a molecular complex: novel role of the $\mathrm{COOH}$-terminal domain. J Gen Physiol. 123:155-165, 2004

Murphy B.J., Rogers J., Perdichizzi A.P., Colvin A.A., Catterall W.A. cAMPdependent phosphorylation of two sites in the $\alpha$ subunit of the cardiac sodium channel. $\mathrm{J}$ Biol Chem. 271:28837-28843, 1996

Ono K., Kiyosue T., Arita M. Isoproterenol, DBcAMP, and forskolin inhibit cardiac sodium current. Am J Physiol Cell Physiol. 256:C1131-C1137, 1989 
Passier R., Zeng H., Frey N., Naya F.J., Nicol R.L., McKinsey T.A., Overbeek P.A., Richardson J.A., Grant S.R., Olson E.N. CaM kinase signaling induces cardiac hypertrophy and activates the MEF2 transcription factor in vivo. J Clin Invest. 105:13951406,2000

Pieske B., Maier L.S., Bers D.M., Hasenfuss G. $\mathrm{Ca}^{2+}$ handling and $\mathrm{Ca}^{2+}$ content in isolated failing and nonfailing human myocardium. Circ Res. 85:38-46, 1999

Pogwizd S.M., Schlotthauer K., Li L., Yuan W., Bers D.M. Arrhythmogenesis and contractile dysfunction in heart failure: roles of sodium-calcium exchange, inward rectifier potassium current, and residual beta-adrenergic responsiveness. Circ Res. 88:1159-1167, 2001

Priebe L., Beuckelmann D.J. Simulation study of cellular electric properties in heart failure. Circ Res. 82:1206-1223, 1998

Priori S.G., Napolitano C., Memmi M., Colombi B., Drago F., Gasparini M., DeSimone L., Coltorti F., Bloise R., Keegan R., Cruz Filho F.E., Vignati G., Benatar A., DeLogu A. Clinical and molecular characterization of patients with catecholaminergic polymorphic ventricular tachycardia. Circulation. 106:69-74, 2002

Priori S.G., Napolitano C., Tiso N., Memmi M., Vignati G., Bloise R., Sorrentino V.V., Danieli G.A. Mutations in the cardiac ryanodine receptor gene (hRyR2) underlie catecholaminergic polymorphic ventricular tachycardia. Circulation. 103:196-200, 2001

Qu Y., Rogers J., Tanada T., Catterall W., Scheuer T. Phosphorylation of S1505 in the cardiac $\mathrm{Na}^{+}$channel inactivation gate is required for modulation by protein kinase C. J Gen Physiol. 108:375-379, 1996

Ramirez M.T., Zhao X., Schulman H., Brown J.H. The nuclear $\delta_{\mathrm{B}}$ isoform of $\mathrm{Ca}^{2+} /$ calmodulin-dependent protein kinase II regulates atrial natriuretic factor gene expression in ventricular myocytes. J Biol Chem. 272:31203-31208, 1997 
Rodriguez P., Bhogal M.S., Coyler J. Stoichiometric phosphorylation of cardiac ryonadine receptor on serine-2809 by calmodulin-dependent kinase II and protein kinase A. J Biol Chem. 278:38593-600, 2003

Saito T., Fukuzawa T., Osaki J., Sakuragi H., Yao N., Haneda T., Fujino T., Wakamiya N., Kikuchi K., Hasebe N. Roles of calcineurin and calcium/calmodulindependent protein kinase II in pressure overload-induced cardiac hypertrophy. J Mol Cell Cardiol. 35:1153-60, 2003

Schillinger W., Janssen P.M., Emami S., Henderson S.A., Ross R.S., Teucher N., Zeitz O., Philipson K.D., Prestle J., Hasenfuss G. Impaired contractile performance of cultured rabbit ventricular myocytes after adenoviral gene transfer of $\mathrm{Na}^{+}-\mathrm{Ca}^{2+}$ exchanger. Circ Res. $87: 581-7,2000$

Schwinger R.H., Munch G., Bölck B., Karczewski P., Krause E.G., Erdmann E. Reduced $\mathrm{Ca}^{2+}$ sensitivity of SERCA2a in failing human myocardium due to reduced serin16 phospholamban phosphorylation. J Mol Cell Cardiol. 31:479-491, 1999

Sedej S, Kockskämper J, Heinzel FR, Groborz J, Gronau P, Dybkova N, Maier LS, Colombi B, Napolitano C, Priori SG, Pieske B. Increased vulnerability to ouabain-induced arrhythmias in myocytes from mouse hearts harboring a human CPVT mutation. $74^{\text {th }}$ Annual Meeting of the German Cardiac Society:P1544, 2008 (Abstract)

Shannon T.R., Pogwizd S.M., Bers D.M. Elevated sarcoplasmic reticulum Ca leak in intact ventricular myocytes from rabbits in heart failure. Circ Res. 93:592-594, 2003

Simmerman H.K.B., Collins J.H., Theibert J.L., Wegener A.D., Jones L.R. Sequence analysis of PLB: identification of phosphorylation sites and two major structural domains. J Biol Chem. 261:13333-41, 1986

Sipido K.R., Volders P.G., Vos M.A., Verdonck F. Altered $\mathrm{Na} / \mathrm{Ca}$ exchange activity in cardiac hypertrophy and heart failure: a new target for therapy? Cardiovasc Res. 53:782805, 2002 
Stühmer W., Conti F., Suzuki H., Wang X.D., Noda M., Yahagi N., Kubo H., Numa S. Structural pats involved in activation and inactivation of the sodium channel. Nature. 339:597-603, 1989

Temsah R.M., Kawabata K., Chapman D., Dhalla N.S. Modulation of cardiac sarcoplasmic reticulum gene expression by lack of oxygen and glucose. FASEB J. 15:2517-7, 2001

Tokumitsu H., Enslen H., Soderling T.R. Characterization of a $\mathrm{Ca}^{2+} /$ calmodulindependent protein kinase cascade: molecular cloning and expression of calcium/calmodulin-dependent protein kinase kinase. J Biol Chem. 270:19320-19324, 1995

Towbin H., Staehelin T., Gordon J. Electrophoretic transfer of proteins from polyacrylamide gels to nitrocellulose sheets: procedure and some applications. Proc Natl Acad Sci. 76:4350-4354, 1979

Veldkamp M.W., Viswanathan P.C., Bezzina C., Baartscheer A., Wilde A.A.M., Balser J.R. Two distinct congenital arrhythmias evoked by a multidysfunctional $\mathrm{Na}^{+}$ channel. Circ Res. 86:91e-97e, 2000

Viswanathan P.C., Balser J.R. Inherited sodium channelopathies: a continuum of channel dysfunction. Trends Cardiovasc Med. 14:28-35, 2004

Vogel H.J. Calmodulin: a versatile calcium mediator protein. Biochem Cell Biol. 72: 357376,1994

Wagner S., Dybkova N., Rasenack E.C.L., Jacobshagen C., Fabritz L., Kirchof P., Maier S.K.G., Zhang T., Hasenfuss G., Brown J.H., Bers D.M., Maier L.S. $\mathrm{Ca}^{2+} /$ calmodulin-dependent protein kinase II regulates cardiac $\mathrm{Na}^{+}$channels. J Clin. Invest. $116: 3127-3138,2006$

Wagner S., Maier L.S. Modulation of cardiac $\mathrm{Na}^{+}$and $\mathrm{Ca}^{2+}$ currents by $\mathrm{CaM}$ and CaMKII. J Cardiovasc Electrophysiol. 17:S26-S33, 2006 
Wagner S., Seidler T., Picht E., Maier L.S., Kazanski V., Teucher N., Schillinger W., Pieske B., Isenberg G., Hasenfuss G., Kögler H. $\mathrm{Na}^{+}-\mathrm{Ca}^{2+}$ exchanger overexpression predisposes to reactive oxygen species-induced injury. Cardiovasc Res. 60:404-12, 2003

Wang D.W., Makita N., Kitabatake A., Balser J.R., George A.L. Enhanced $\mathrm{Na}^{+}$ channel intermediate inactivation in Brugada syndrome. Circ Res. 87:E37-E43, 2000

Watson C.L., Gold M.R. Lysophosphatidylcholine modulates cardiac $\mathrm{I}_{\mathrm{Na}}$ via multiple protein kinase pathways. Circ Res. 81:387-395, 1997

Wehrens X.H., Lehnart S.E., Huang F., Vest J.A., Reiken S.R., Mohler P.J., Sun J., Guatimosim S., Song L.S., Rosemblit N., D’Armiento J.M., Napolitano C., Memmi M., Priori S.G., Lederer W.J., Marks A.R. FKBP 12.6 deficiency and defective calcium release channel (ryanodine receptor) function linked to exercise-induced sudden cardiac death. Cell. 113:829-40, 2003

Wehrens X.H., Lehnart S.E., Reiken S.R., Marks A.R. $\mathrm{Ca}^{2+} /$ calmodulin-dependent protein kinase II phosphorylation regulates the cardiac ryanodine receptor. Circ Res. 94:e61-70, 2004

Witcher D.R. Kovacs R.J., Schulman H., Cefali D.C., Jones L.R. Unique phosphorylation site on the cardiac ryanodine receptor regulates calcium channel activity. $\mathrm{J}$ Biol Chem. 266:11144-52, 1991

Witcher D.R., Kovacs R.J., Schulman H., Cefali D.C., Jones L.R. Unique phosphorylation site on the cardiac ryanodine receptor regulates calcium channel activity. $\mathrm{J}$ Biol Chem. 266:11144-52, 1991

Wu Y., Colbran R.J., Anderson M.E. Calmodulin kinase is a molecular switch for cardiac excitation-contraction coupling. Proc Natl Acad Sci. 98:2877-81, 2001 
Wu Y., MacMillan L.B., McNeill R.B., Colbran R.J., Anderson M.E. CaM kinase augments cardiac L-type $\mathrm{Ca}^{2+}$ current: a cellular mechanism for long Q-T arrhythmias. Am J Physiol. 276:H2168-H2178, 1999

Wu Y., Roden D.M., Anderson M.E. Calmoduline kinase inhibition prevents development of the arrhythmogenic transient inward current. Circ Res. 84:906-912, 1999

Wu Y., Temple J., Zhang R., Dzhura I., Zhang W., Trimble R., Roden D.M., Passier R., Olson E.N., Colbran R.J., Anderson M.E. Calmodulin kinase II and arrhythmias in mouse model of cardiac hypertrophy. Circulation. 106:1288-1293, 2002

Xiao R.P., Cheng H., Lederer W.J., Suzuki T., Lakatta E.G. Dual regulation of Ca/ calmodulin kinase II activity by membrane voltage and by calcium influx. Proc Natl Acad Sci. 91:9659-63, 1994

Yang D., Zhu W.Z, Xiao B., Brochet D.X.P., Chen S.R.W., Lakatta E.G., Xiao R.P., Heping Cheng H. $\mathrm{Ca}^{2+} /$ calmodulin kinase II-dependent phosphorylation of ryanodine receptors suppresses $\mathrm{Ca}^{2+}$ sparks and $\mathrm{Ca}^{2+}$ waves in cardiac myocytes. Circ Res. 100:399407, 2007

Yano M., Ikeda Y., Matsuzaki M. Altered intracellular $\mathrm{Ca}^{2+}$ handling in heart failue. J Clin Invest. 115:556-564, 2005

Yuan W., Bers D.M. Ca-dependent facilitation of cardiac $\mathrm{Ca}$ current is due to Cacalmodulin dependent protein kinase. Am J Physiol. 267:H982-93, 1994

Zeng J., Rudy Y. Early afterdepolarizations in cardiac myocytes: mechanism and rate dependence. Biophys J. 68:949-964, 1995

Zhang R., Khoo M.S.C., Wu Y., Yang Y., Grueter C.E., Ni G., Price E.E., Thiel W., Guatimosin S., Song L.S., Madu E.C., Shah A.N., Vishnivetskaya T.A., Atkinson J.B., Gurevich V.V., Salama G., Lederer W.J., Colbran R.J., Anderson M.E. Calmodulin kinase II inhibition protects against structural heart disease. Nat Med. 11:409-17, 2005 
Zhang T., Brown J.H. Role of $\mathrm{Ca}^{2+} /$ calmodulin-dependent protein kinase II in cardiac hypertrophy and heart failure. Cardiovasc Res. 63:476-486, 2004

Zhang T., Johnson E.N., Gu Y., Morissette M.R., Sah V.P., Gigena M.S., Belke D.D., Dillmann W.H., Rogers T. B., Schulman H., Ross J. Jr., Brown J.H. The cardiacspecific nuclear $\delta_{\mathrm{B}}$ isoform of $\mathrm{Ca} /$ calmodulin-dependent protein kinase II induces hypertrophy and dilated cardiomyopathy associated with increased protein phosphatase $2 \mathrm{~A}$ activity. J Biol Chem. 277:1261-1267, 2002

Zhang T., Maier L.S., Dalton N.D., Miyamoto S., Ross J.J., Bers D.M., Brown J.H. The $\delta_{\mathrm{C}}$ isoform of CaMKII is activated in cardiac hypertrophy and induces dilated cardiomyopathy and heart failure. Circ Res. 92:912-9, 2003

Zhu W.S., Wang S.Q., Charik K., Yang D., Zhang T., Brown J.H, Devic E., Kobilka B.K., Cheng H., Xiao R.P. Linkage of beta 1-adrenergic stimulation to apoptotic heart cell death through protein kinase A-independent activation of $\mathrm{Ca}^{2+} /$ calmodulin kinase II. J Clin Invest. 111:617-25, 2003

Zwadlo C., Borlak J. Disease-associated changes in the expression of ion channels, ion receptors, ion exchangers and $\mathrm{Ca}^{2+}$-handling proteins in heart hypertrophy. Toxicol Appl Pharmacol. 207:244-256, 2005 


\section{Acknowledgements}

I would like to thank Professor Lars Maier for giving me the opportunity to work on this project, for his generous help and constant support.

I am very grateful to Professor Rüdiger Hardeland for reviewing my $\mathrm{PhD}$ thesis and to Professor Detlef Doenecke for being my coreviewer.

I want to give my special thanks to Dr. Darya Zibrova and Astrid Steen from whom I learned the best laboratory practice, for their help in my work.

I am thankful to Dr. Stefan Wagner and Dr. Stefan Neef for their help and cooperation, for teaching me confocal and epifluorescence microscopy. I appreciate their helpful advice and the time they spent discussing our results.

I thank Dr. Michael Kohlhaas and Dr. Can Sag for their cooperation, practical advice and the answers to all my questions.

I want to give my special thanks to Timo Schulte and Thomas Sowa for their help in organizing my work and for their constant support.

My warm thanks to all my colleagues, with whom I worked side by side over the last few years in the department, for the creation of a scientific working atmosphere.

I am thankful to Gudrun Müller for the huge yields of isolated rabbit cardiomyocytes.

My very special thanks I give to my husband, Sasha, for his wholehearted and active support, patience and understanding.

Finally, I want to give a very special thanks to my mother for her moral support that was so necessary for me during this whole period. 


\section{Appendix}

\section{Curriculum Vitae}

Personal data

Name

Nataliya Dybkova

Date of birth

7.12.1972

Place of birth

Kiev, Ukraine

Citizenship

Ukraine

Marital status

Married

\section{Education}

1979-1992

1993-1998

School education, Kiev, Ukraine

University study

Biological faculty of Kiev National Taras Shevchenko University, Kiev, Ukraine

1997

Degree: Bachelor of Science in biology, teacher of biology

Bachelor scientific project "The effect of nerobol anabolic on $\mathrm{Na}^{+} / \mathrm{K}^{+}$-ATPase activity of microsomes of sceletal, unstriped and heart muscles"

1998

2003-2005

Degree: Specialist of Science in biochemistry, teacher of biology

Specialist scientific project "Investigation of the effect of acetylsalicylic acid on the state of membranes of endoplasmatical reticulum of the rat liver under conditions of their intoxication by tetrachlormethane",

Research assistant in Department of Cardiology and Pneumology of Georg-August University Clinic (Göttingen)

March 2005-May 2008 Experimental work for the present dissertation in Department of Cardiology and Pneumology of Georg-August University Clinic (Göttingen)

\section{Publications}

1. Maier LS, Wahl-Schott C, Horn W, Weichert S, Pagel C, Wagner S, Dybkova N, Müller OJ, Näbauer M, Franz WM, Pieske B. Increased $\mathrm{SR} \mathrm{Ca}^{2+}$ cycling contributes to improved contractile performance in SERCA2a-overexpressing transgenic rats. Cardiovasc Res. 67:636-646.2005.

2. Kohlhaas M, Zhang T, Seidler T, Zibrova D, Dybkova N, Steen A, Wagner S, Chen L, Heller Brown J, Bers DM, Maier LS. Increased sarcoplasmic reticulum calcium leak but 
unaltered contractility by acute CaMKII overexpression in isolated rabbit cardiac myocytes. Circ Res. 98:235-244.2006.

3. Wagner S, Dybkova N, Rasenack ECL, Jacobshagen C, Fabritz L, Kirchhof P, Maier SKG, Zhang T, Hasenfuss G, Heller Brown J, Bers DM, Maier LS. Ca/calmodulindependent protein kinase II regulates cardiac Na channels. J Clin Invest. 116:31273138.2006.

4. Yurukova S, Kilić A, Leineweber K, Dybkova N, Maier LS, Brodde O-E, Kuhn M. $\mathrm{Ca}^{2+} /$ Calmodulin kinase II - mediated increased cardiac relaxation responses to $B-$ adrenergic receptor stimulation in ANP receptor deficient mice. Cardiovasc Res. 73:678688.2007.

5. Sag CM, Dybkova N, Neef S, Maier LS. Effects on recovery during acidosis in cardiac myocytes overexpressing CaMKII. J Mol Cell Cardiol. 43:696-709.2007.

6. Zhang T, Kohlhaas M, Backs J, Phillips W, Mishra S, Dybkova N, Chang S, Bers DM, Maier LS, Olson EN, Heller Brown J. Cytoplasmic and nuclear isoforms of CaMKII differentially affect calcium handling but similarly regulate HDAC/MEF2 transcriptional response. J Biol Chem. 282:35078-35087.2007.

7. Wagner S, Hacker E, Dybkova N, Fabritz L, Kirchhof P, Bers DM, Maier LS. $\mathrm{Ca} /$ calmodulin kinase II differentially modulates transient outward potassium current in heart failure. Circulation. (in Revision).

8. Dybkova N., Sedej S., Napolitano C., Neef S., Rokita A.G., Hünlich M., Kockskämper J., Priori S.G., Pieske B., Maier L.S. Overexpression of CaMKII $\delta_{C}$ in RyR2 ${ }^{\mathrm{R} 4496 \mathrm{C}}$ knock-in mice leads to spontaneous sudden cardiac death and altered intracellular $\mathrm{Ca}^{2+}$ handling. Circulation. (submitted)

\section{Abstracts}

1. Kohlhaas M, Seidler T, Zhang T, Zibrova D, Dybkova N, Heller Brown J, Bers DM, Maier LS. Intracellular calcium handling in isolated rabbit cardiac myocytes overexpressing cytoplasmic vs. nuclear CaMKII isoform. Europ Heart J. 25 (Suppl):178179.2004 . 
2. Dybkova N, Wagner S, Bers DM, Maier LS. First evidence of the association of CaMKII $\delta \mathrm{c}$ with the cardiac Na channel. Z Kardiol. 95 (Suppl 1):V262.2006.

3. Kohlhaas M, Dybkova N, Bers DM, Maier LS. CaMKII-Inhibition vermindert das diastolische SR Ca Leck. Z Kardiol. 95 (Suppl 1):P963.2006.

4. Wagner S, Hacker E, Dybkova N, Fabritz L, Kirchhof P, Bers DM, Maier LS. $\mathrm{Ca} /$ Calmodulin Kinase II differentially modulates transient outward potassium current in heart failure. Circulation. 114 (Suppl II):60.2006.

5. Knöll R, Pfeiffer C, Maier LS, Dybkova N, Chen J, Hasenfuss G, Chien KR. A new MLP interacting protein (MiP1) is an important mediator in human cardiomyopathy. Z Kardiol. 96 (Suppl 1):V1776.2007.

6. Rokita AG, Unsöld B, Teucher N, Schmidt K, Sowa T, Hünlich M, Dybkova N, Neef S, Wagner S, Maier LS. Differential regulation of $\mathrm{Ca} /$ calmodulin-dependent protein kinase II (CaMKII) in cardiac hypertrophy in the mouse: pressure overload versus volume overload. Circulation. 116 (Suppl II):154-155.2007.

7. Dybkova N, Napolitano C, Rokita AG, Neef S, Hünlich M, Kockskämper J, Priori SG, Pieske B, Maier LS for the CONTICA study group. Overexpression of CaMKIIIc in RyR2R4496C knock-in mice leads to spontaneous sudden cardiac death and altered intracellular Ca handling. 74. Jahrestagung der DGK:V49.2008.

8. Sedej S, Kockskämper J, Heinzel FR, Groborz J, Gronau P, Dybkova N, Maier LS, Colombi B, Napolitano C, Priori SG, Pieske B. Increased vulnerability to ouabain-induced arrhythmias in myocytes from mouse hearts harboring a human CPVT mutation. $74^{\text {th }}$ Annual Meeting of the German Cardiac Society:P1544.2008. 